\title{
WAS POSTKARTEN
}

ERZÄHLEN KÖNNEN...

S. KEMPGEN KONSTANZ

XXXIII, 2006

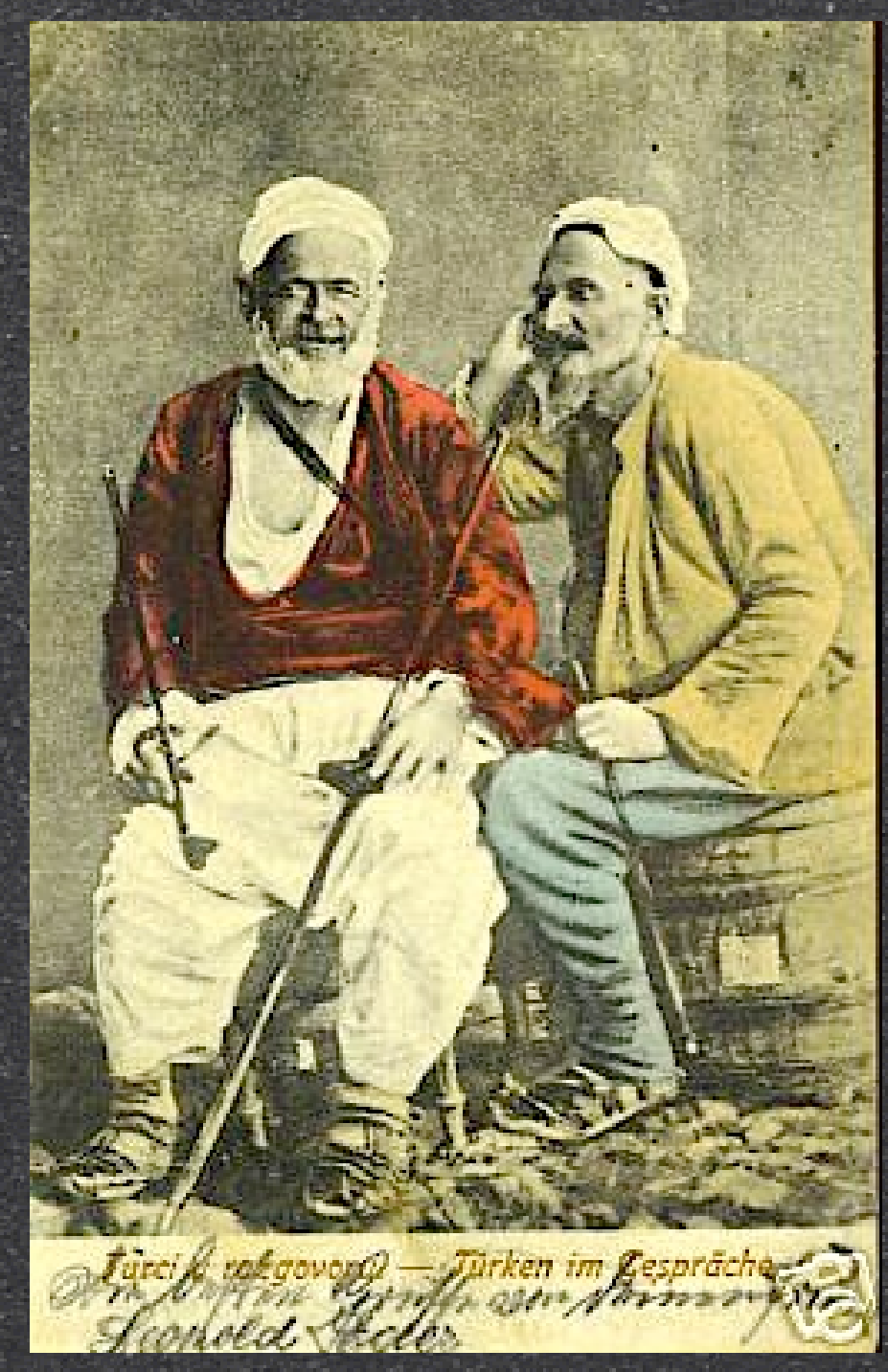




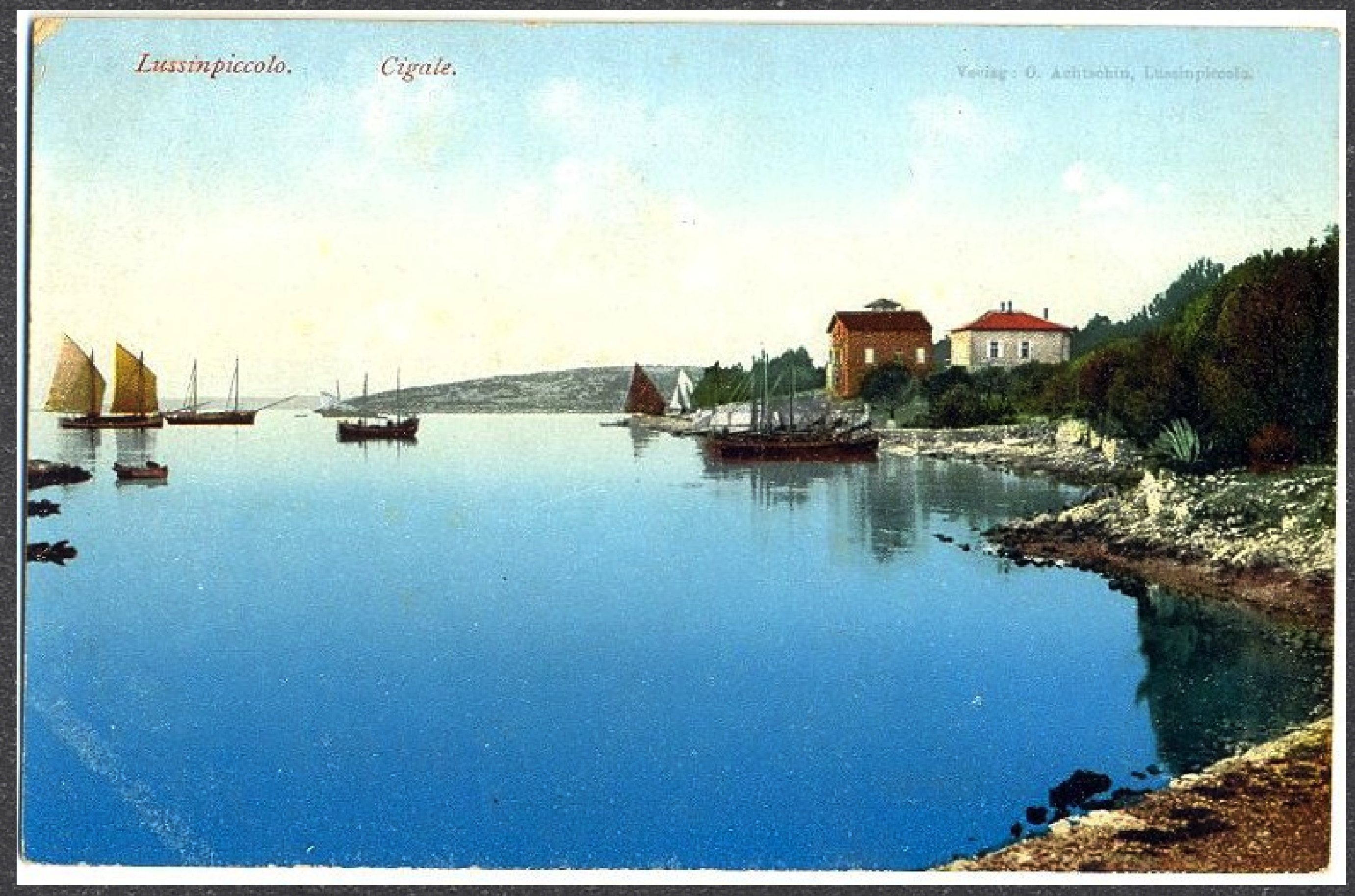




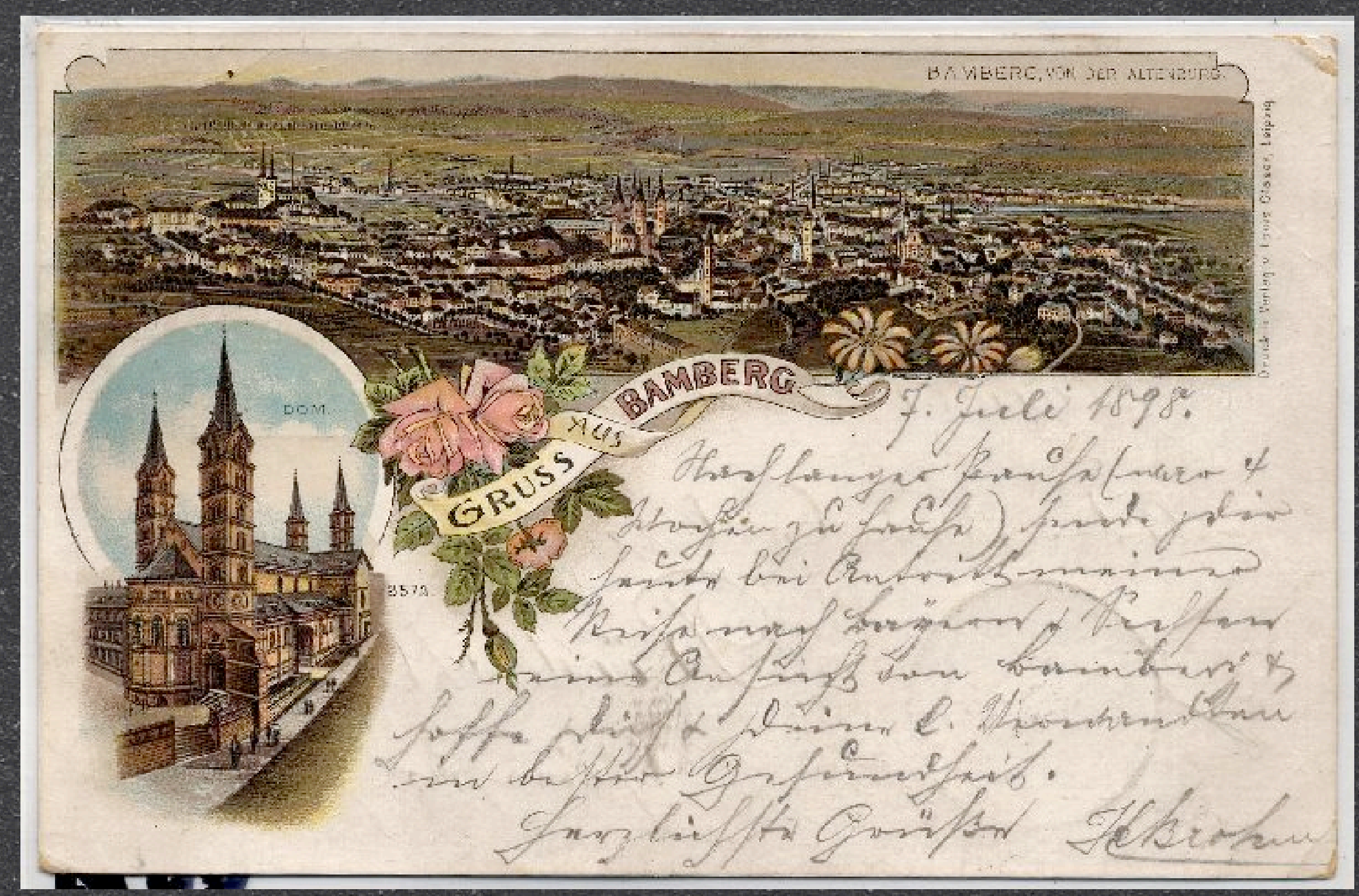




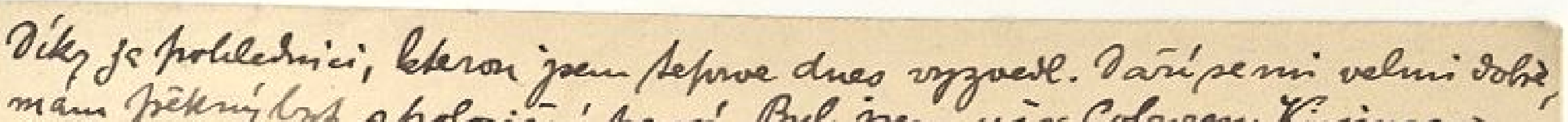

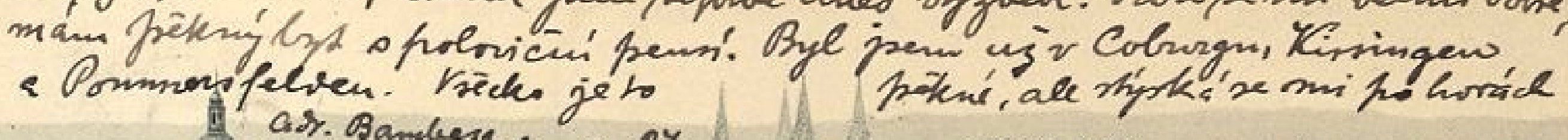

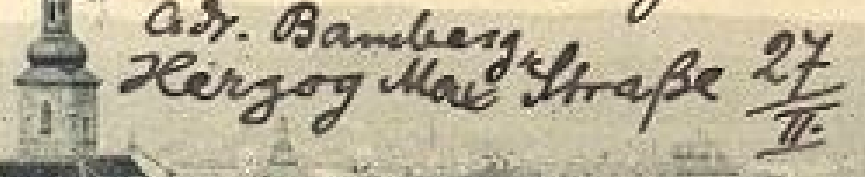

29.VI1.gor.

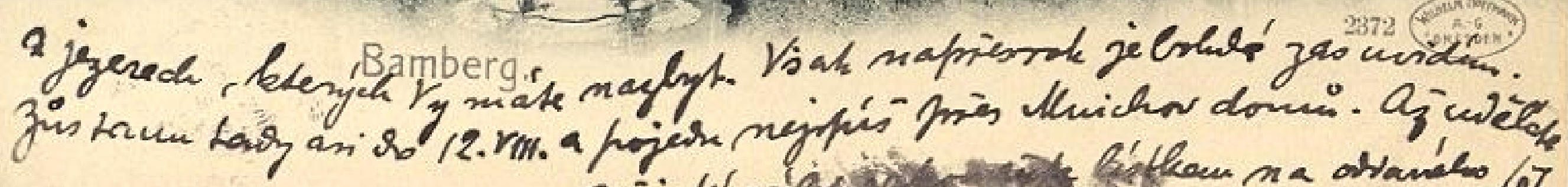

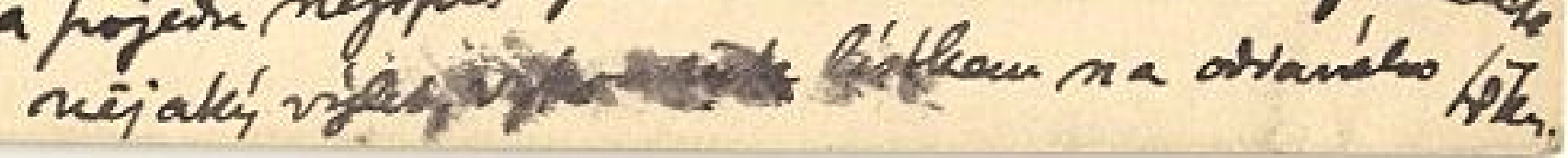


Allg. D. Schulverein z. Erhalt. d, Deutscht. im Ausland

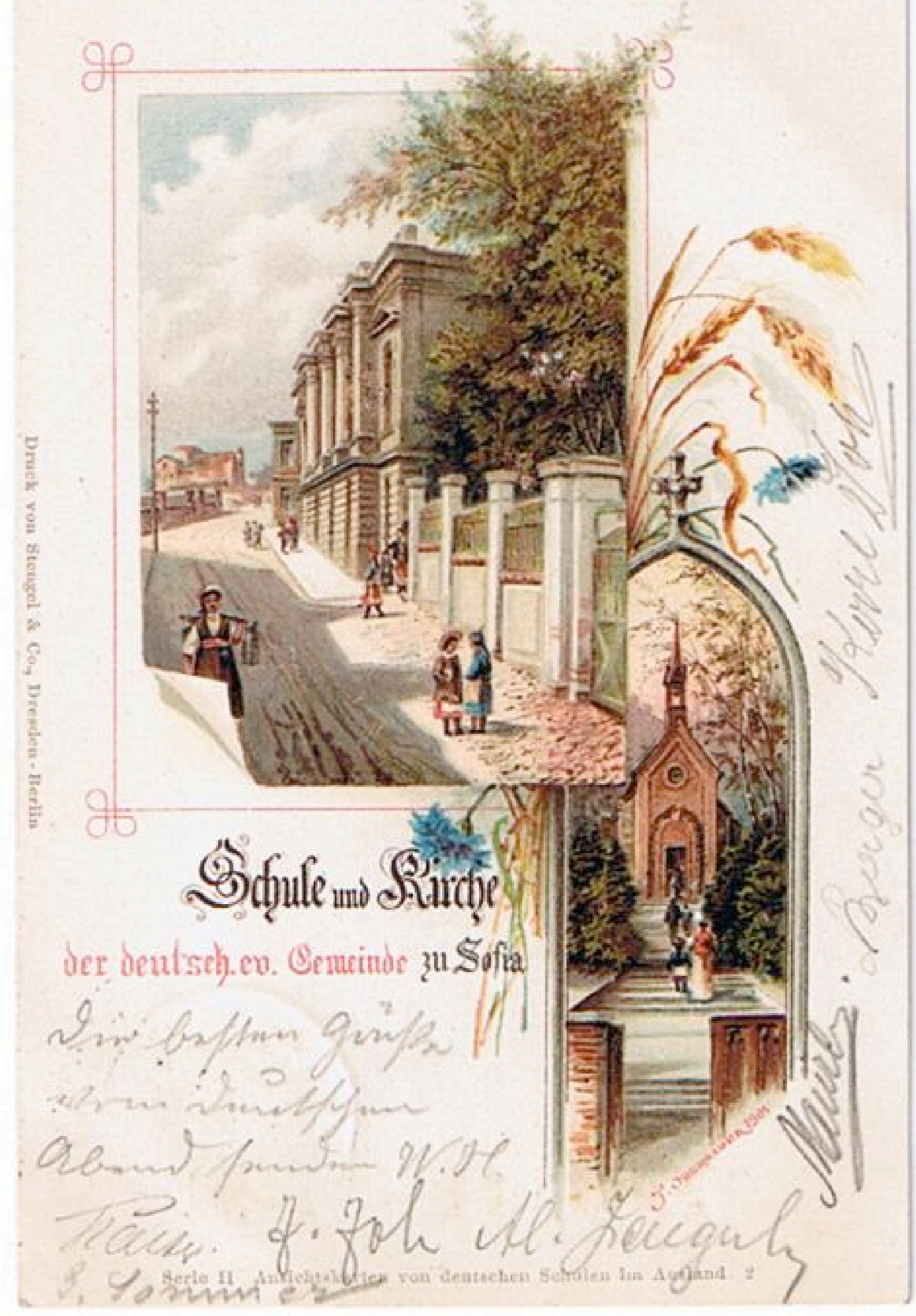




\section{Postkarte.}

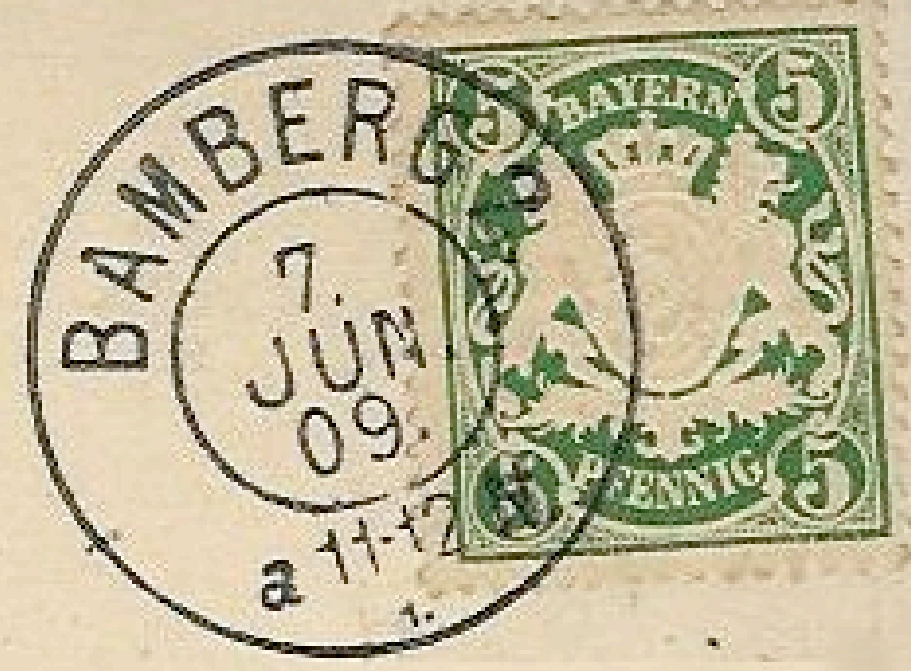

Philatelistische

Anmerkungen 


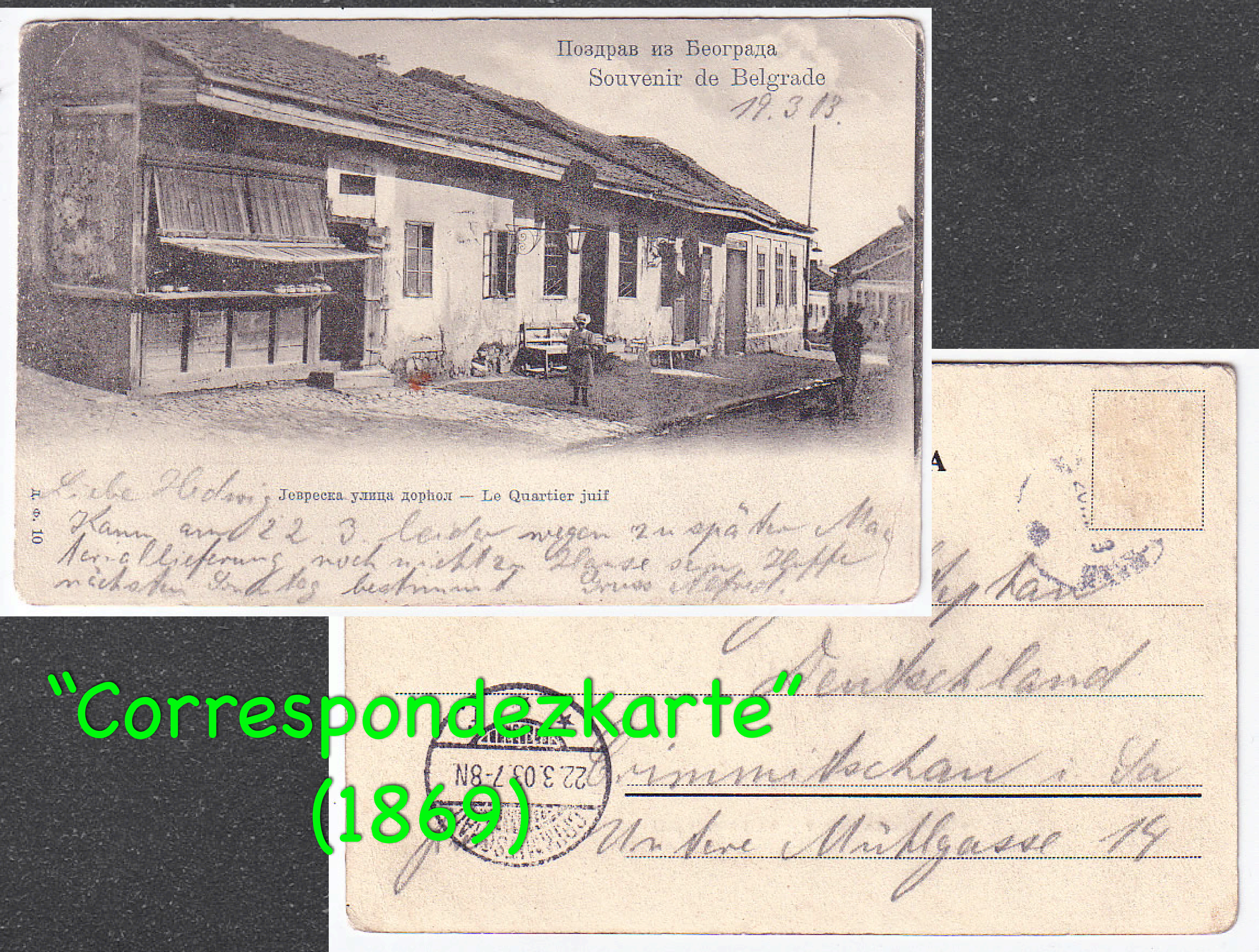




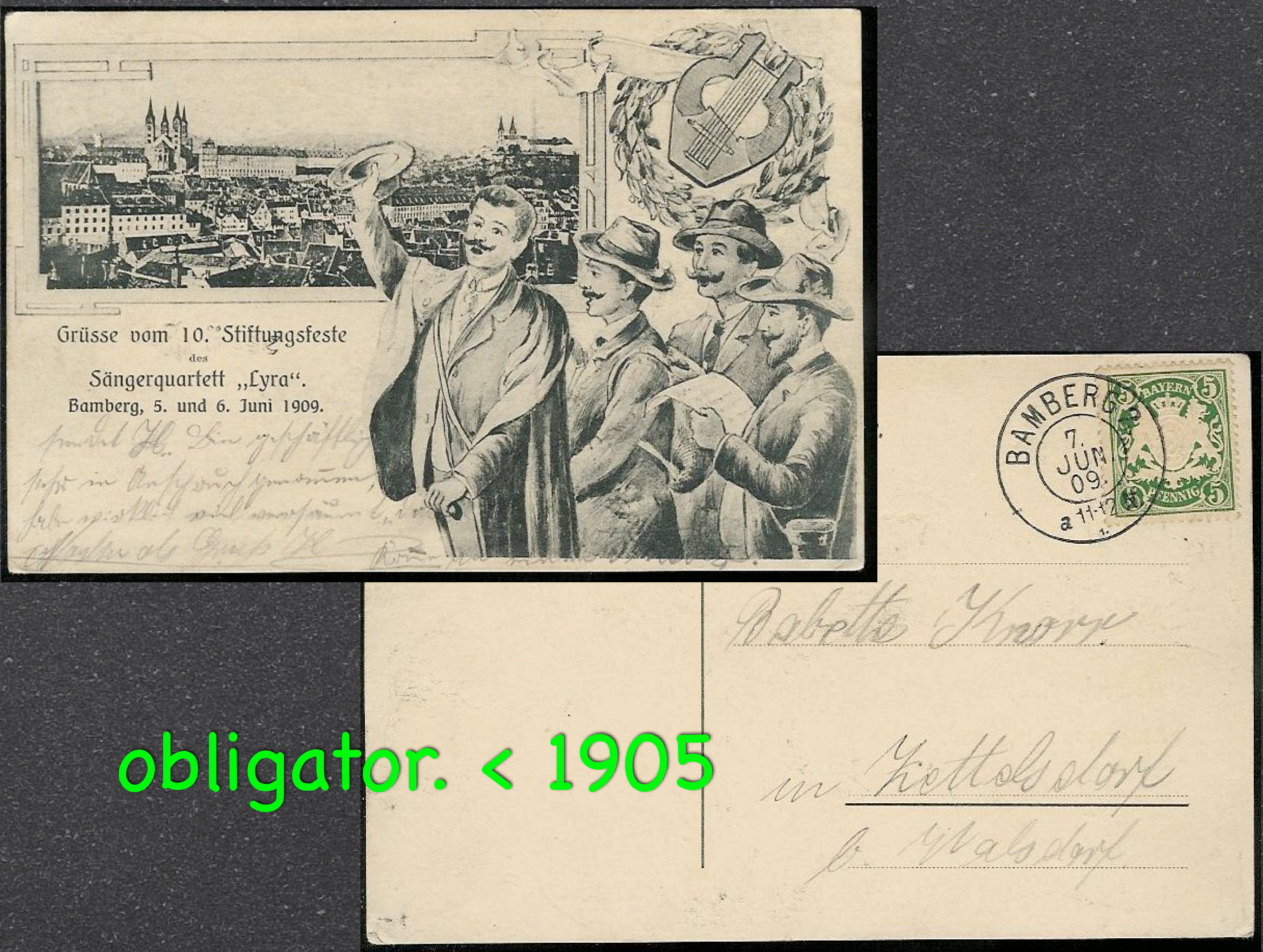




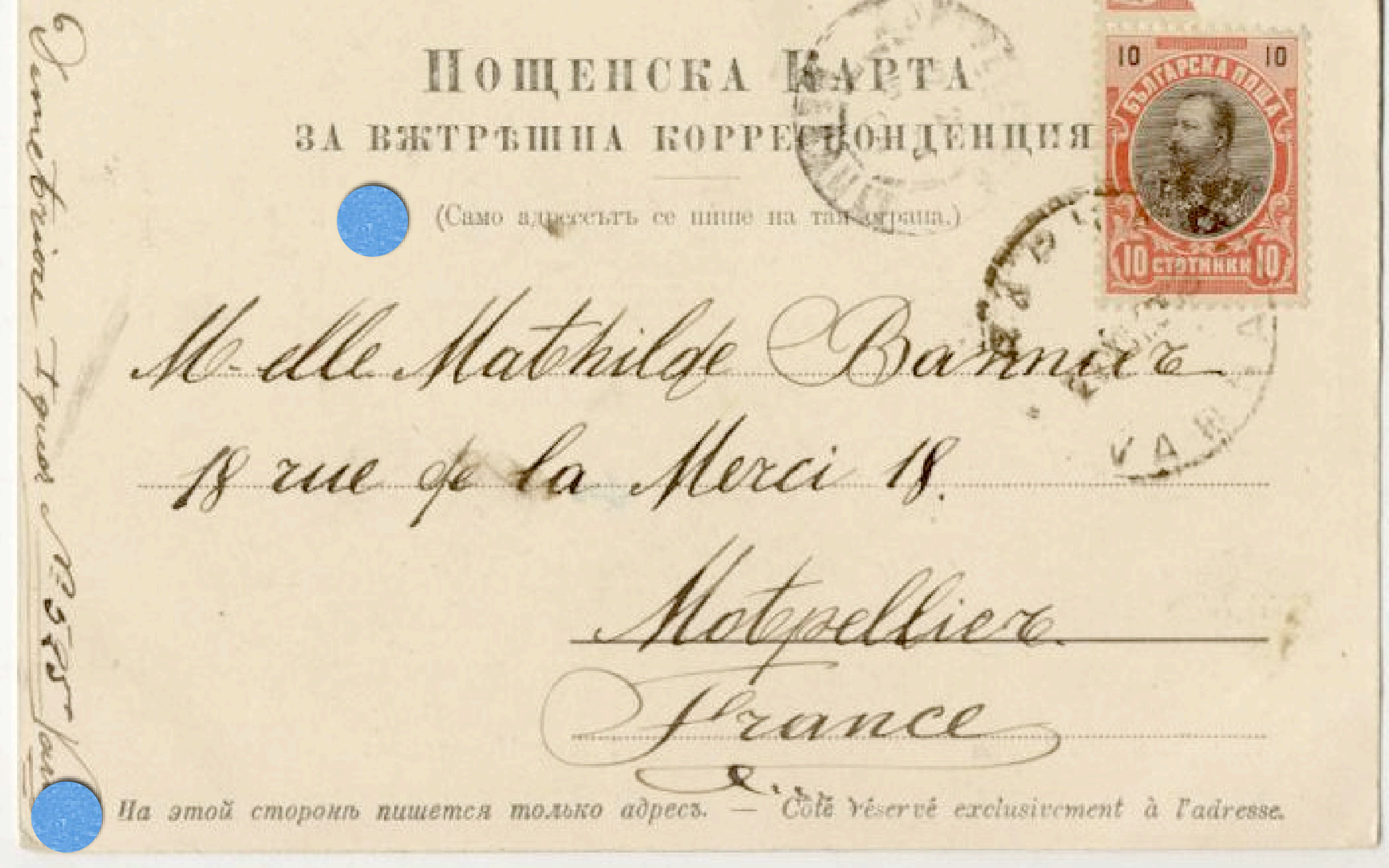

sicherheitshalber mit Hinweis... 


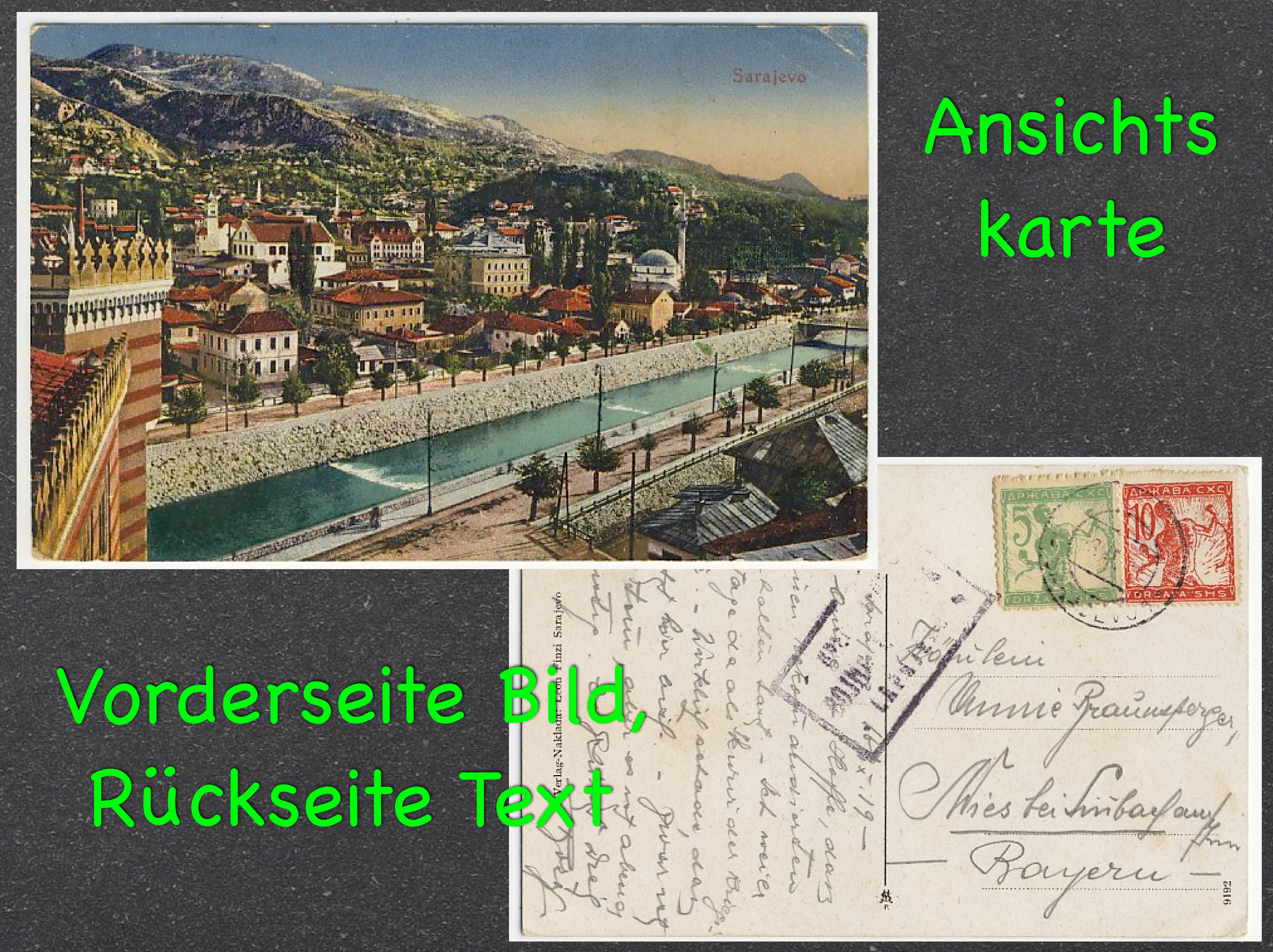


Postkarten

...linguistisch

\section{Postkarte.}

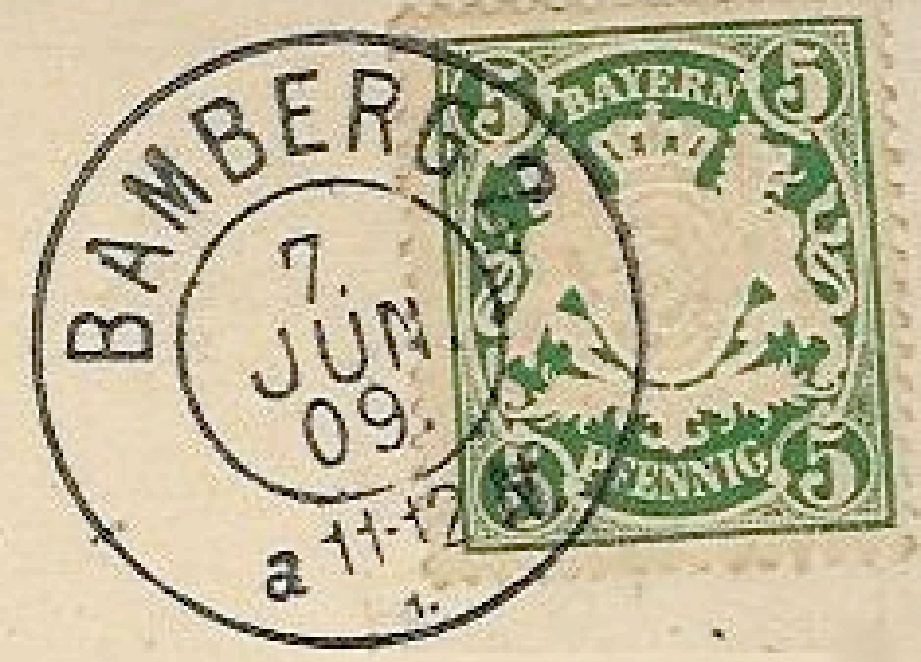

...soziologisch, psychologisch

...thematisch, biographisch

...ökonomisch, touristisch

...philatelistisch 


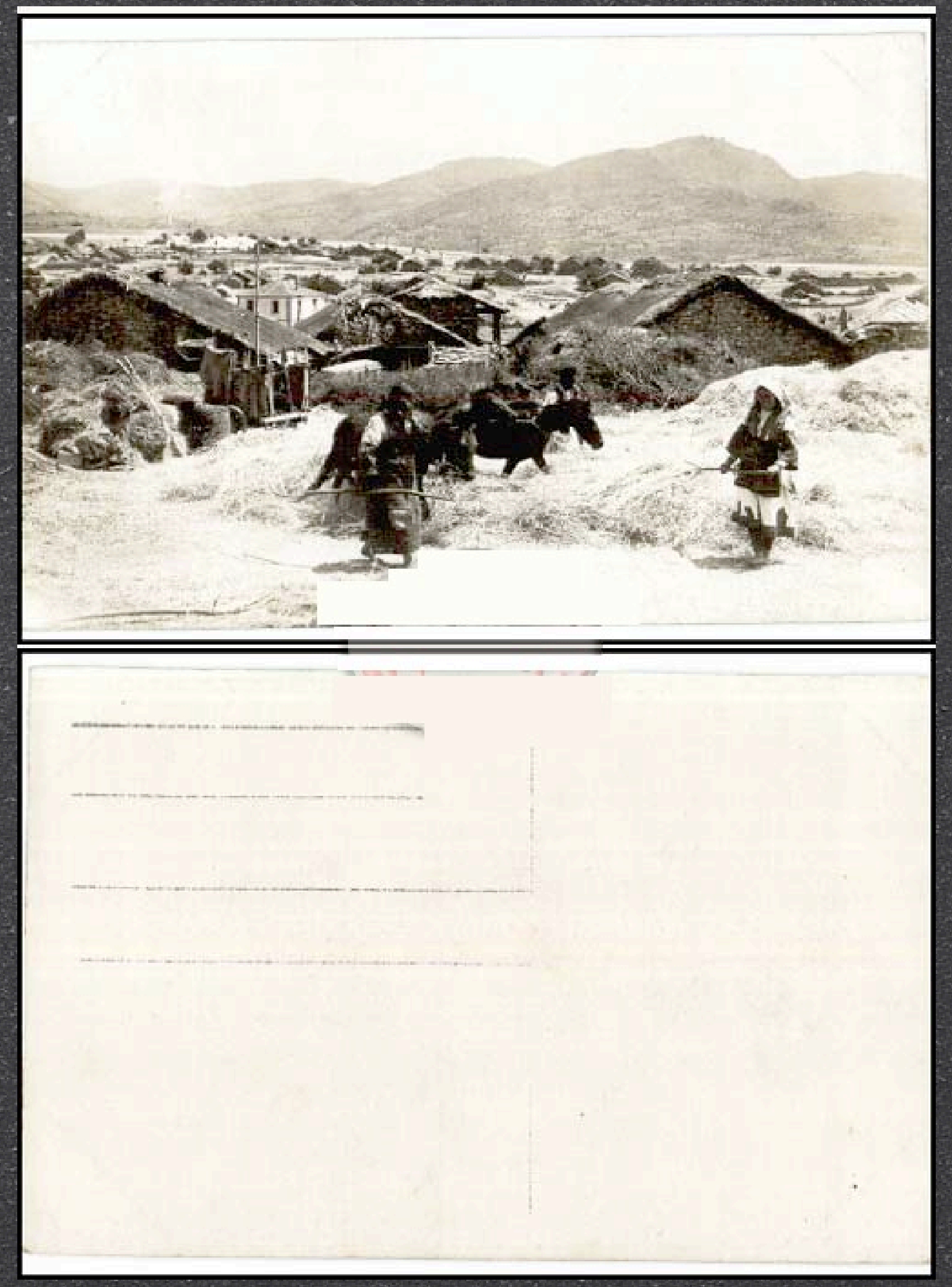

\author{
nicht \\ gelaufen \\ VS: \\ gelaufen
}



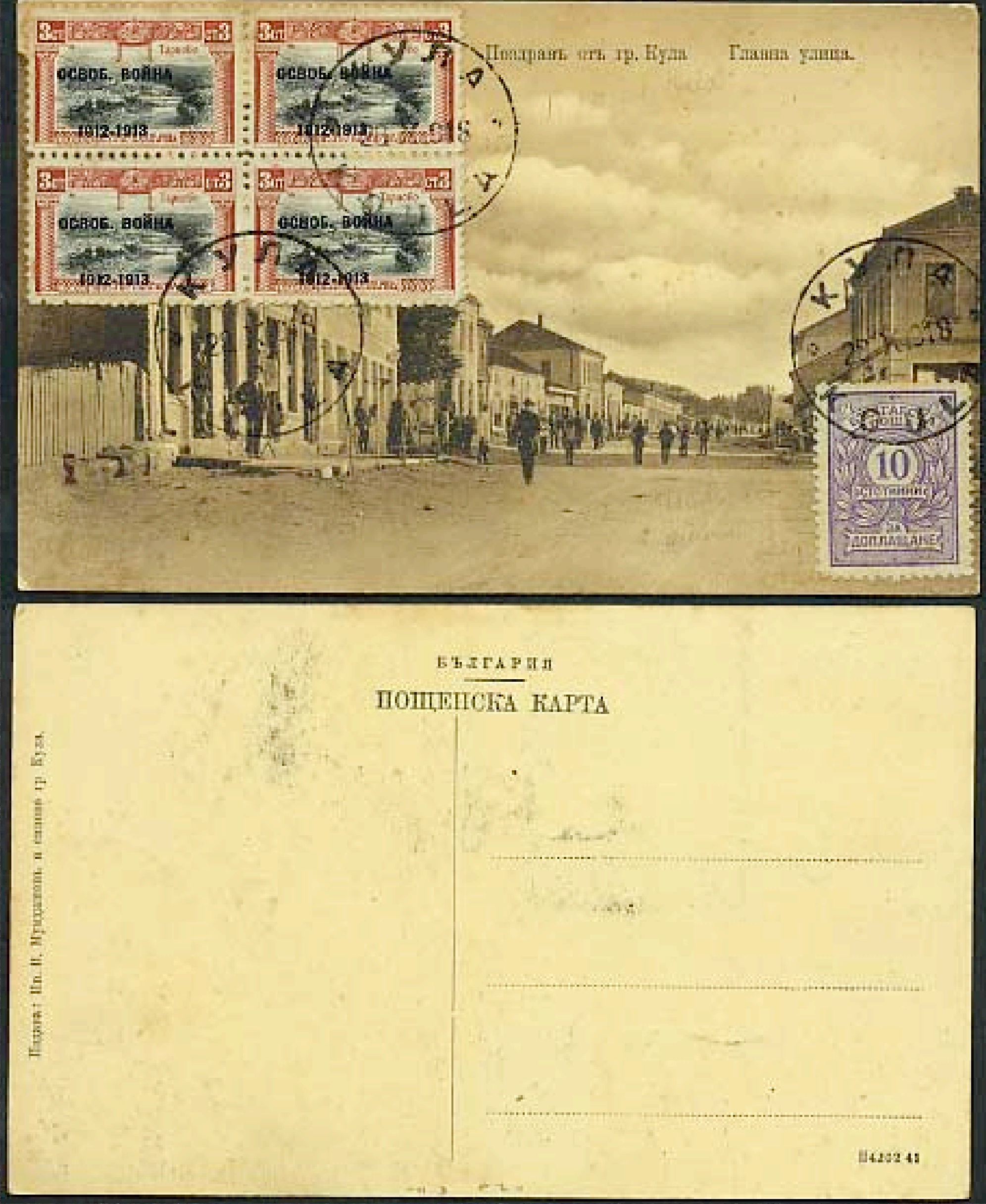


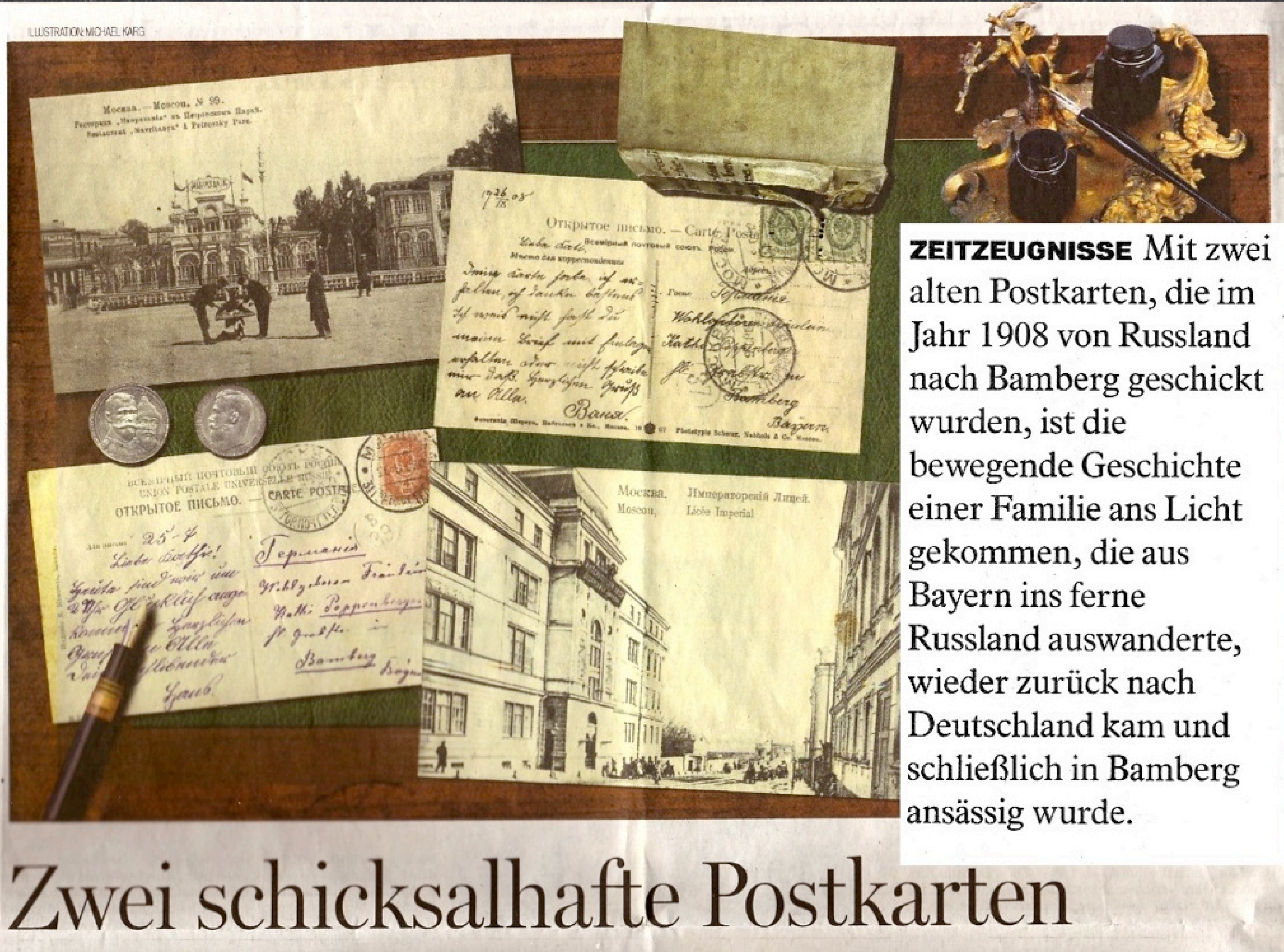




\section{BULGARIA}

120.

Interessengemeinschaft der Bulgariensammler ARGE, Mitglied im BDPh

Startseite $>$ Aus unseren Arbeiten > Palastpost Teil 2

\section{"Post aus dem Palast" - die königliche Palastpost in Bulgarien von 1884 bis 1946 - Teil 2}

Nachrichten und Termine

Aus unseren Arbeiten

Wir aber uns

Phila

von Fokko Kool [ Shmuely

Fortsetzung und Sch Rundbrief Nummer 6 Bestellformular finde

überblick über alle

Ressourcen frühesten und am

Impressum und Kontakt

\section{Sofia}

Mitglieder-

Type I

bereich

Anzeigen

Type III

Type V

\section{Band 1:}

Bulgarien's Provisorien

1884 und 1885

von Dr. Georgi Popov

Der erste Band der ARGE Bulgarla Schriftenreihe ist ein 44 seitiges Buch in DIN A4 mit meist farbigen

Abbildungen. Ausführlich

wird das Aufdruck-

verfahren, das Druckbild, die Echtheitsmerkmale und die Verwendung der ersten Aufdruckprovisorien

Bulgariens von 1884 und

1885 gezeigt und năher

erläutert. Im Anhang findet

man eine Katalogisierung

mit Preisbewertung.

Ein Buch das nicht nur jeder Bulgariensammler, sondern auch jeder Klassikliebhaber in seiner Bibliothek haben muss.

Zusammen mit dem Buch haben wir eine inhaltsgleiche $C D-$

ROM mit der Arbeit im pdf-Format veröffentlicht. Zu beziehen Zu beziehen ist das Buch über die aktuelle Literaturliste zum ist das Buch für 40 Euro und die CD-ROM für 20 Euro von unserer aktuellen Literaturliste

\section{ARCE Bulgaria Schriftenreihe}

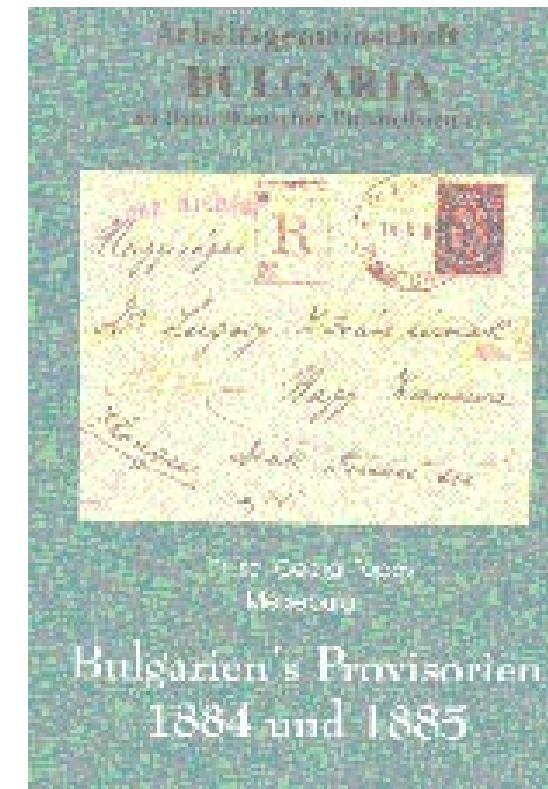

NEU - Band 2:

Die bulgarische Dorfpost von den Anfängen bis zur Moderne

von Thomas Hitzler

Das zweite Werk der Schriftenreihe der ARGE Bulgaria in BDPh bespricht auf 115 Seiten in DIN A4 Format die Entwicklung der bulgarischen Dorfpost ab 1882 bis in die 60er Jahre des 20. Jahrhunderts. Es handelt sich um die erste detaillierte Veroffentlichung uber diese Facette der bulgarischen Postgeschichte. In der Einführung wird die Geschichte mit den wichtigsten postalischen Vorschriften aufgearbeitet. Der Hauptteil listet alle bekannten Stempeltypen der Dorfpost an hand von etwa $200 \mathrm{Abb}$. auf. Ein Katalogteil und Worterbuch rundet das Werk ab. Preis von 48 Euro (für Mitglieder der ARGE: 43 Euro).

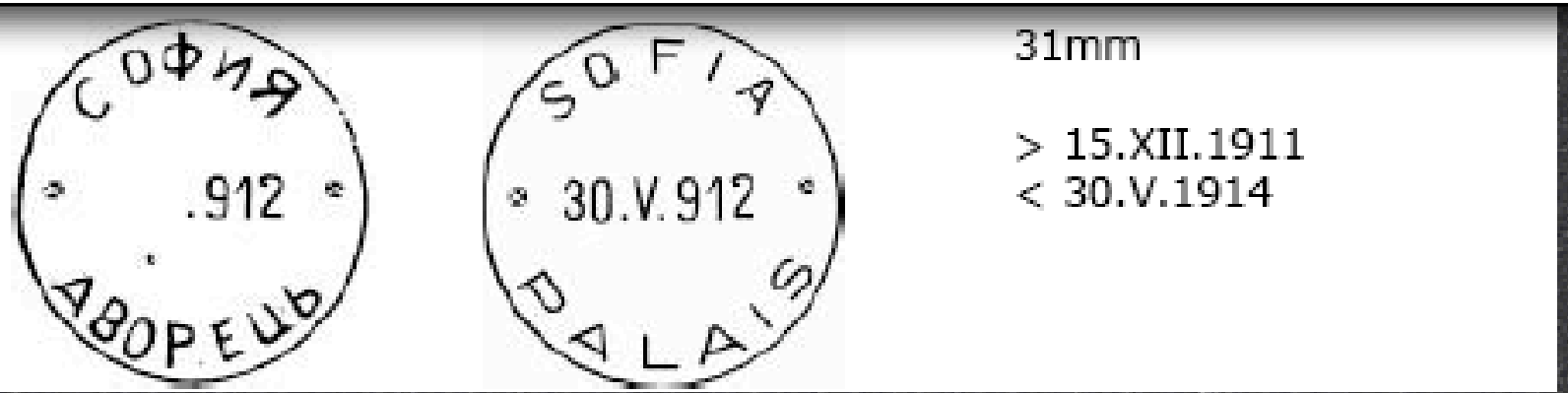




\section{Postkarte.}

Bildseite

...ästhetisch

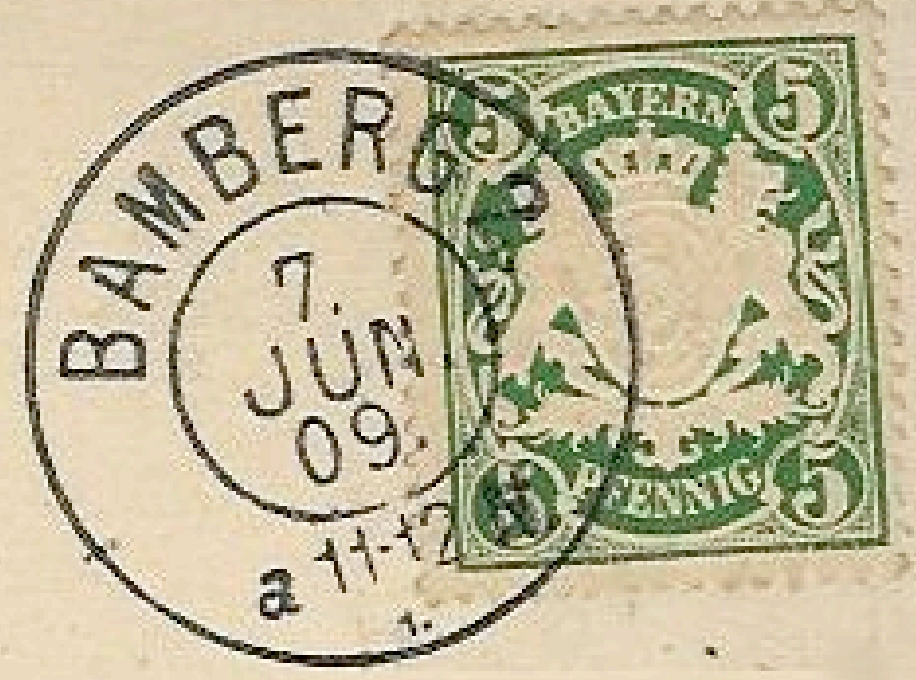

...thematisch

...kulturgeschichtlich

...photographiegeschichtlich

...betriebswirtschaftlich 


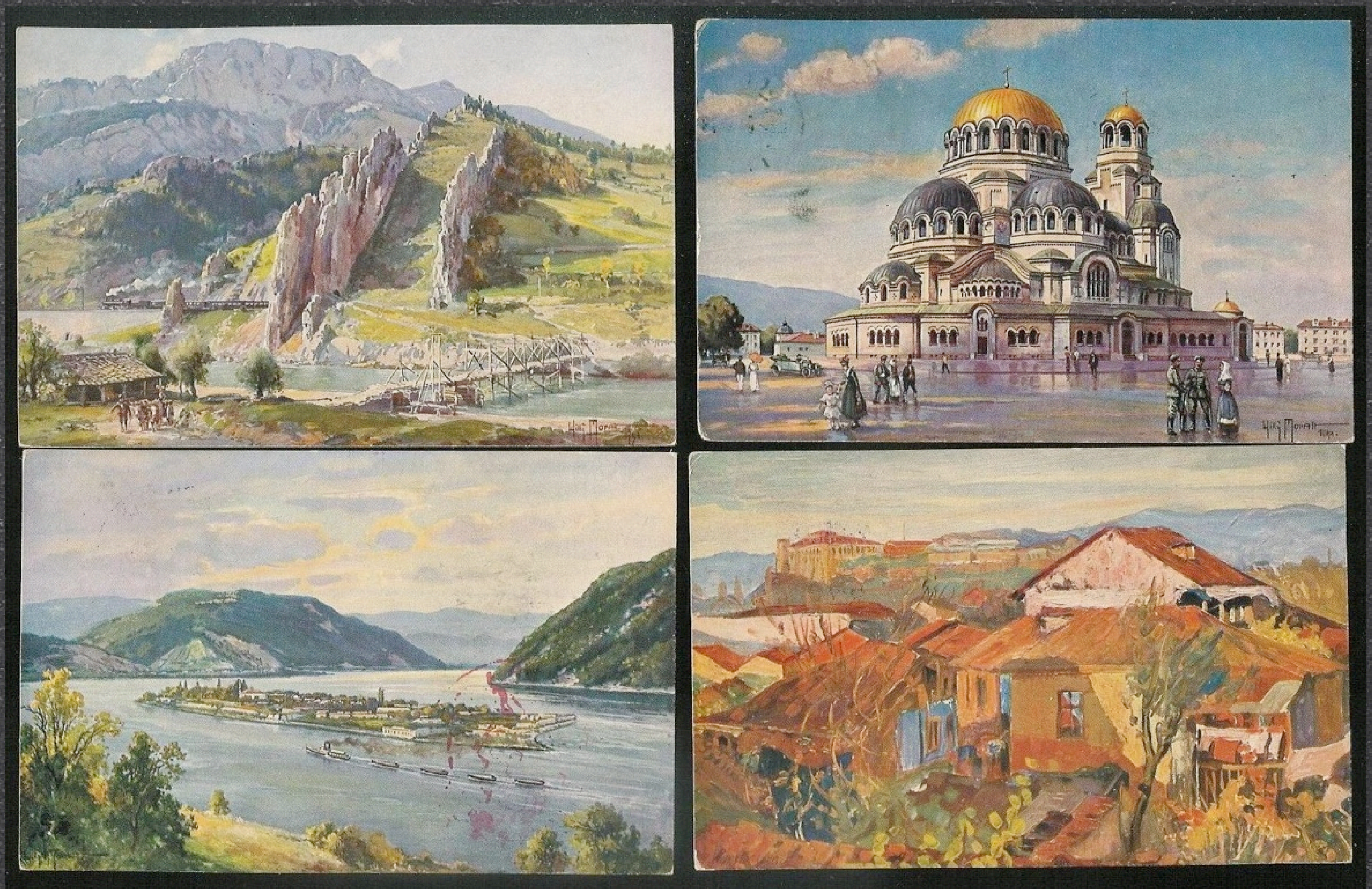

\section{Aquarell-Postkarten}




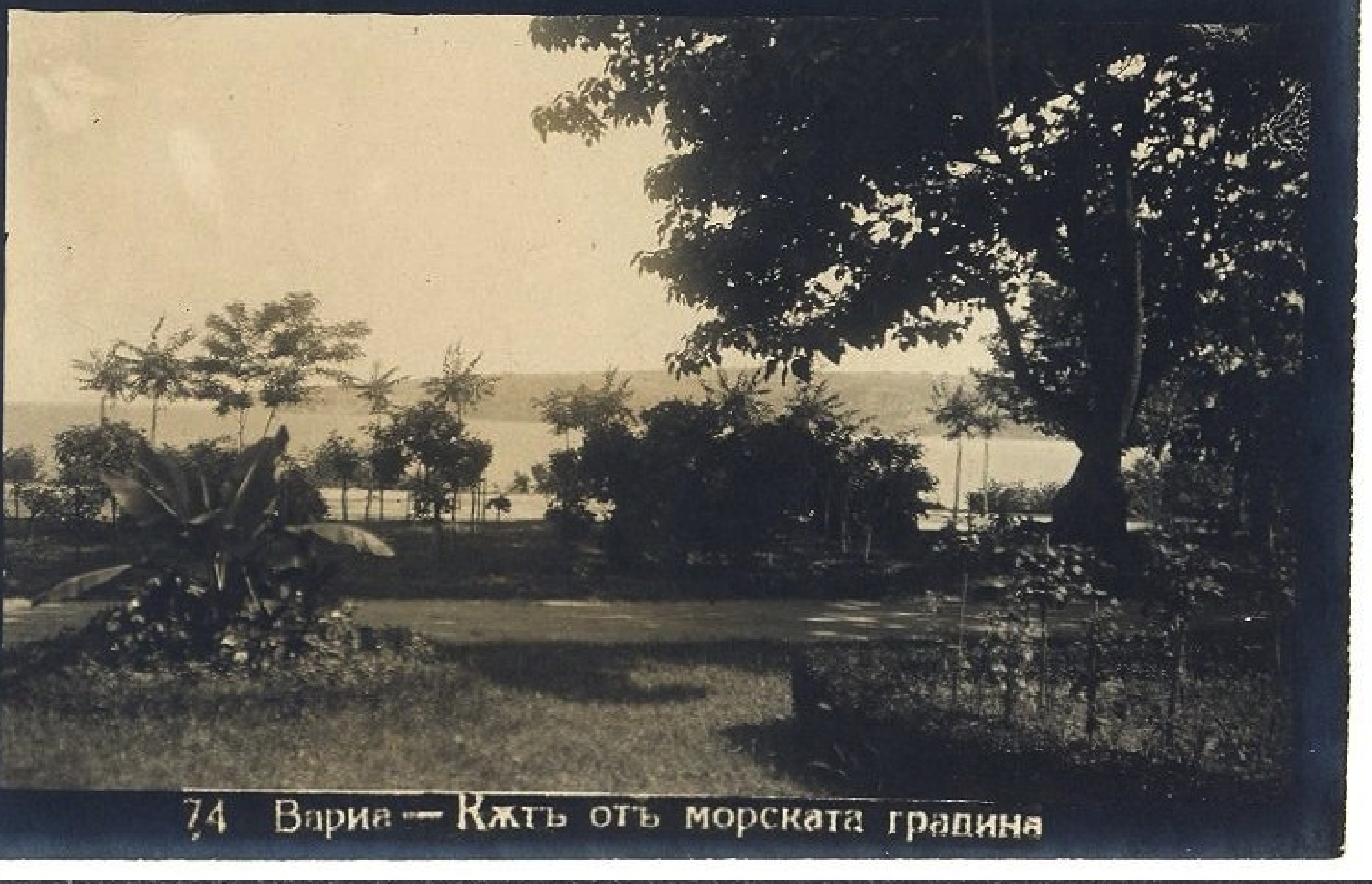




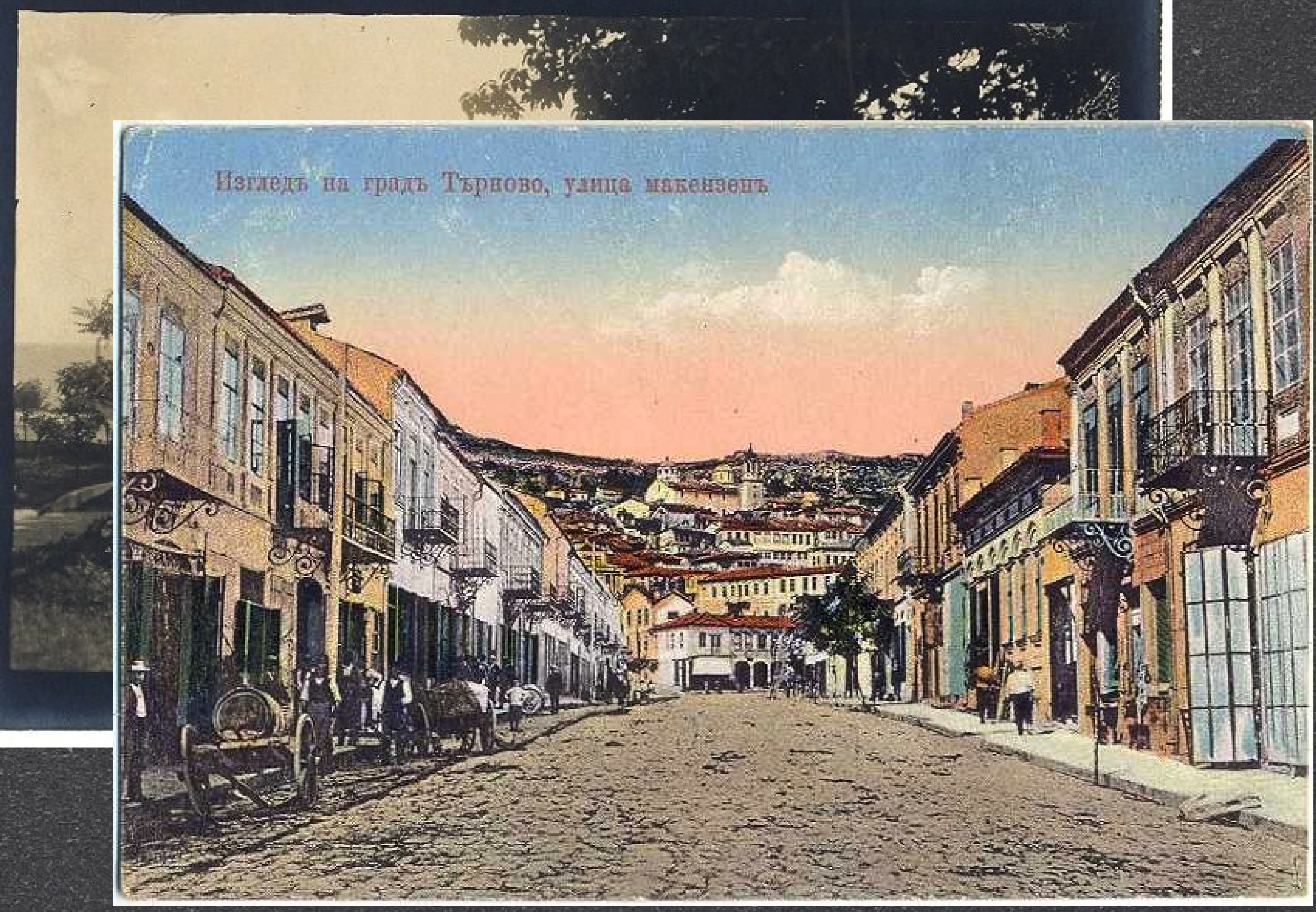




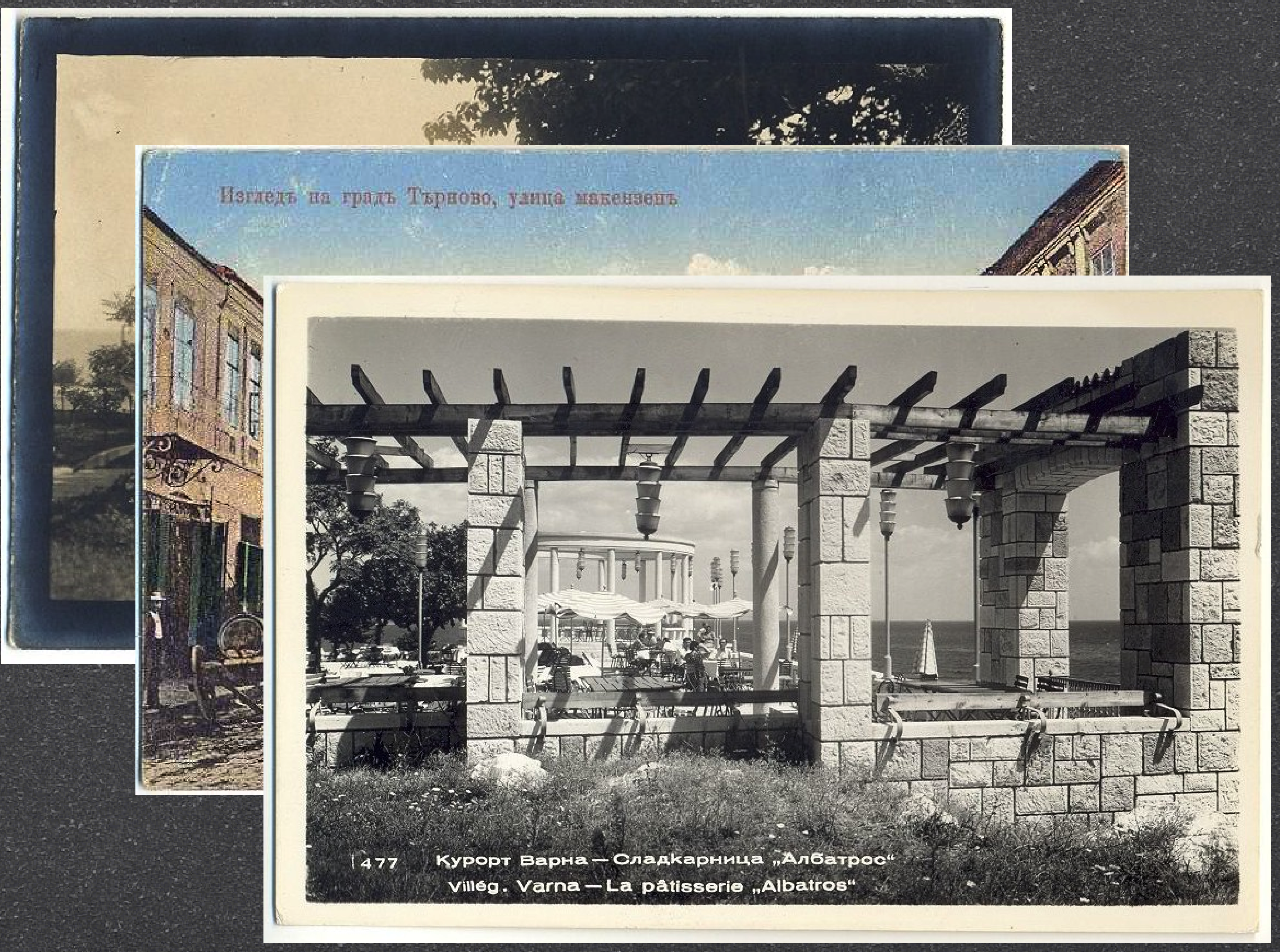



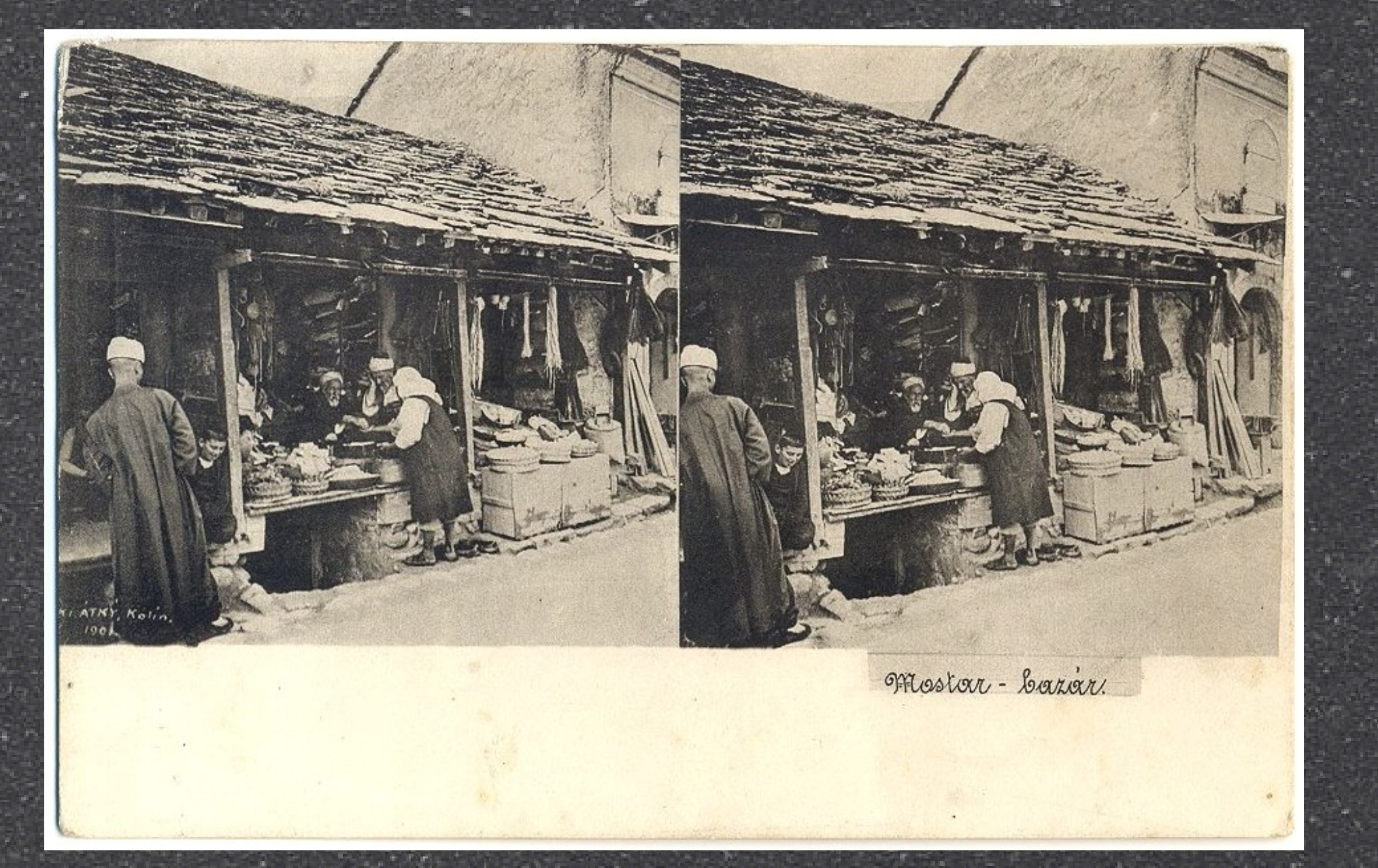


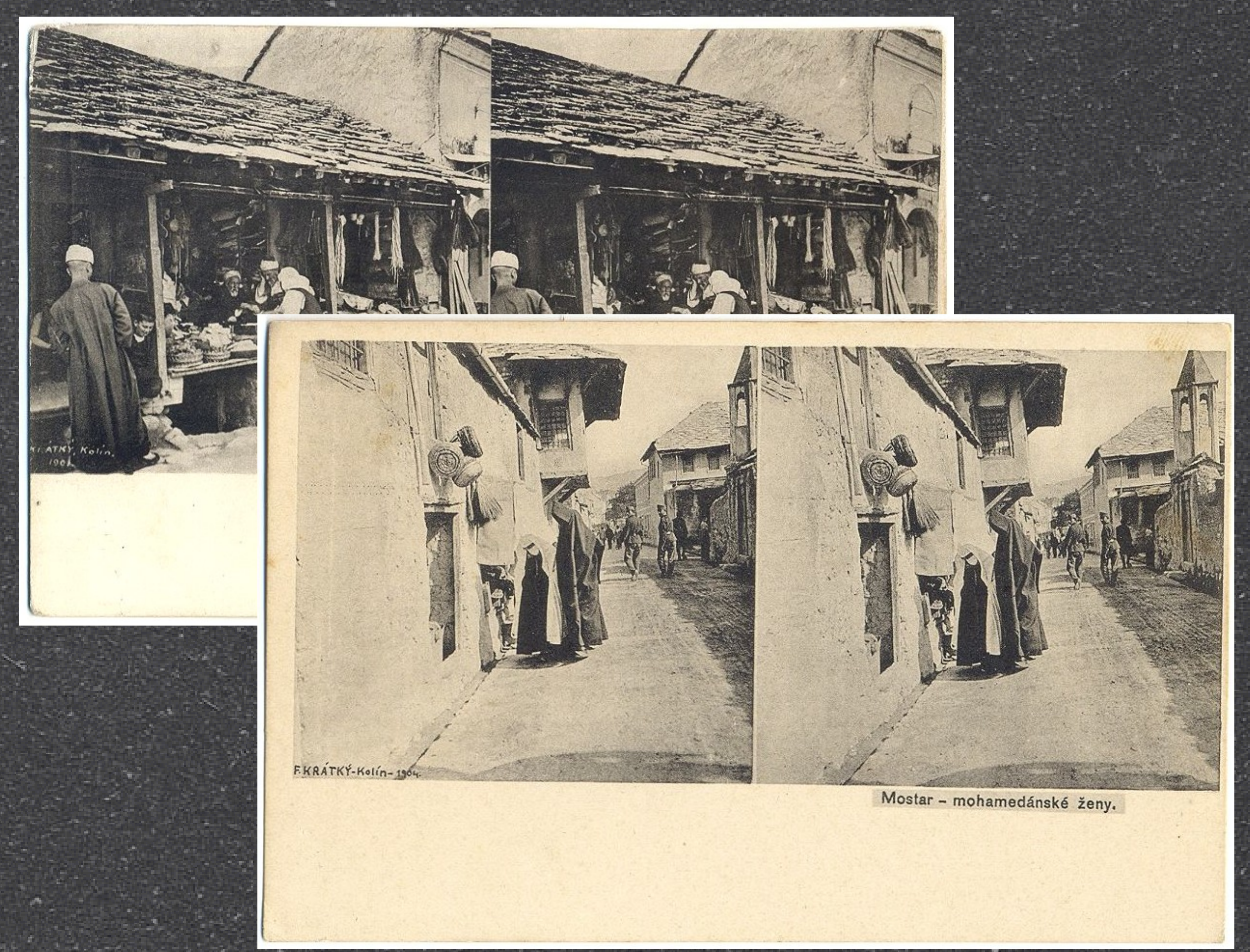




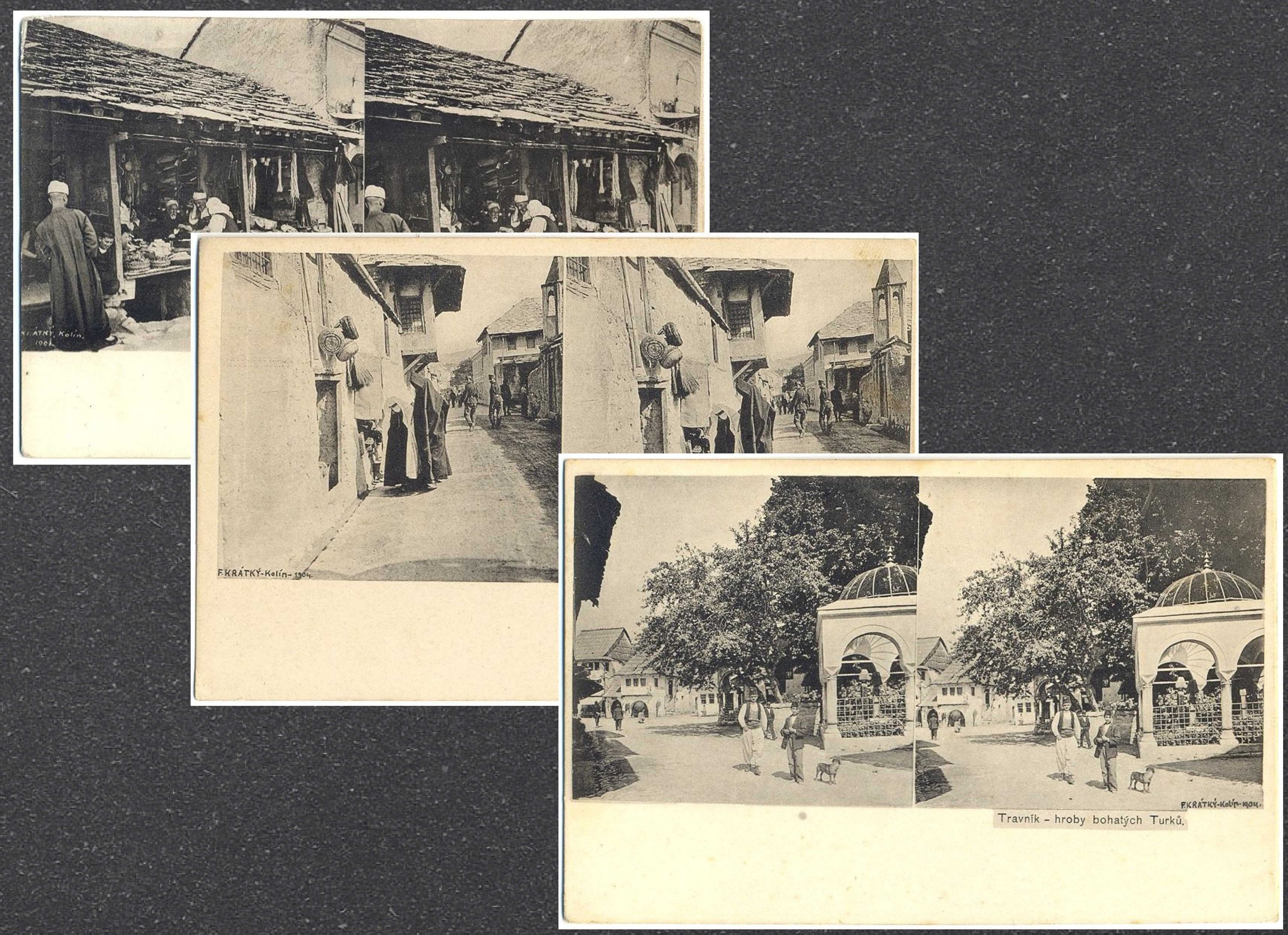




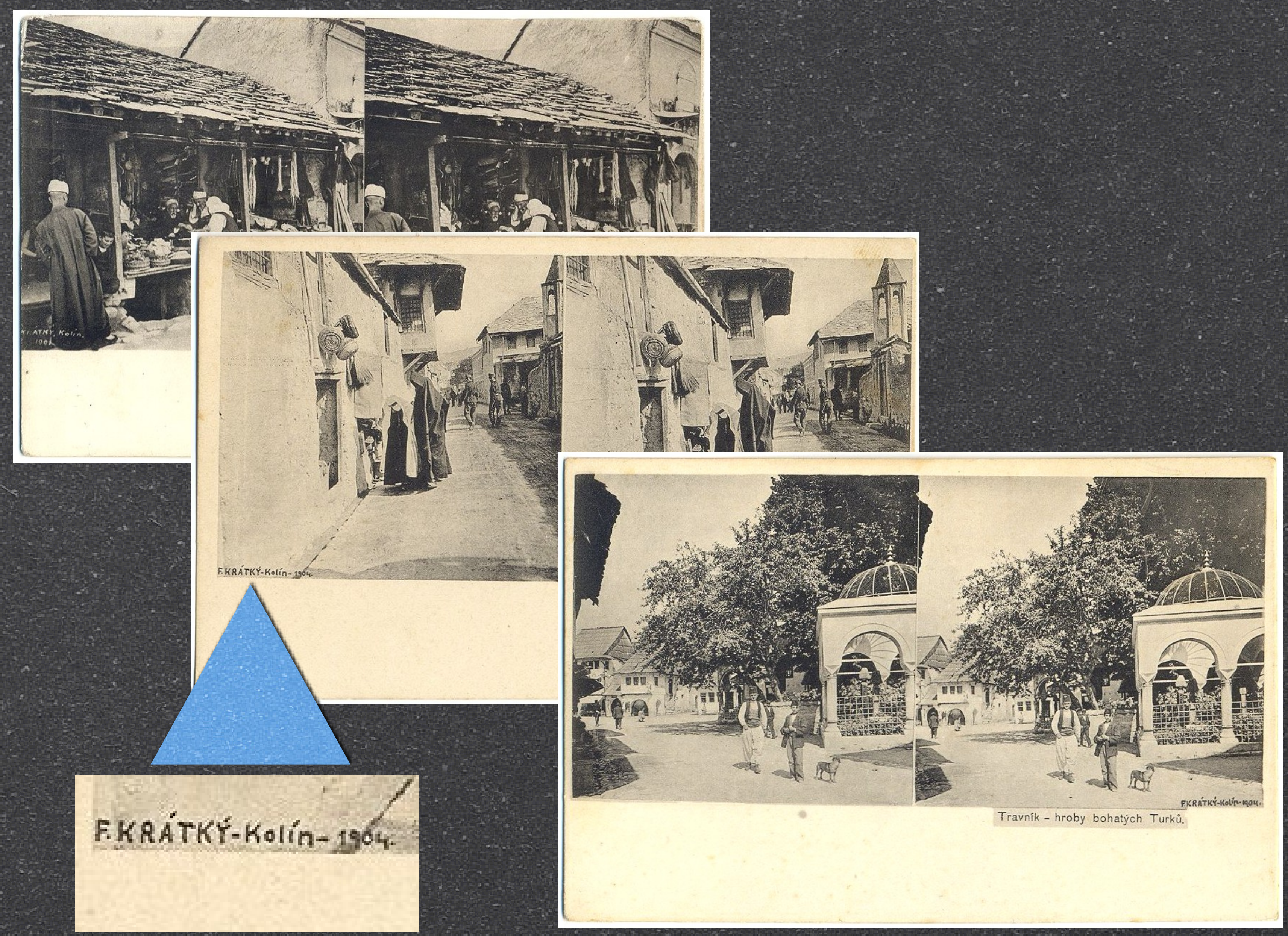




\section{Postkarte.}

Bildseite

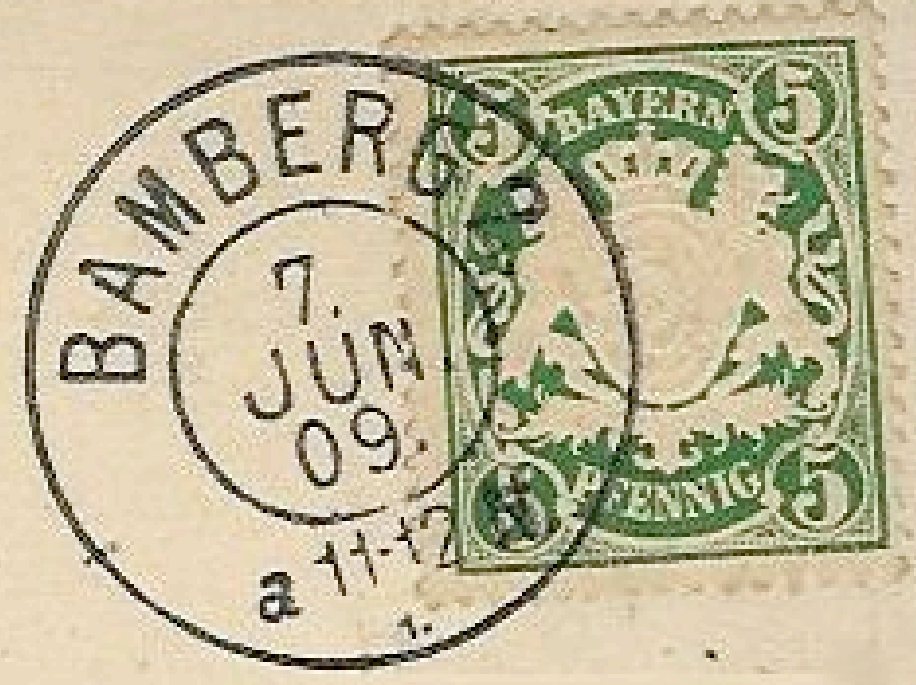
...ethnographisch ...historisch ...Genderaspekte ...Political Correctness 

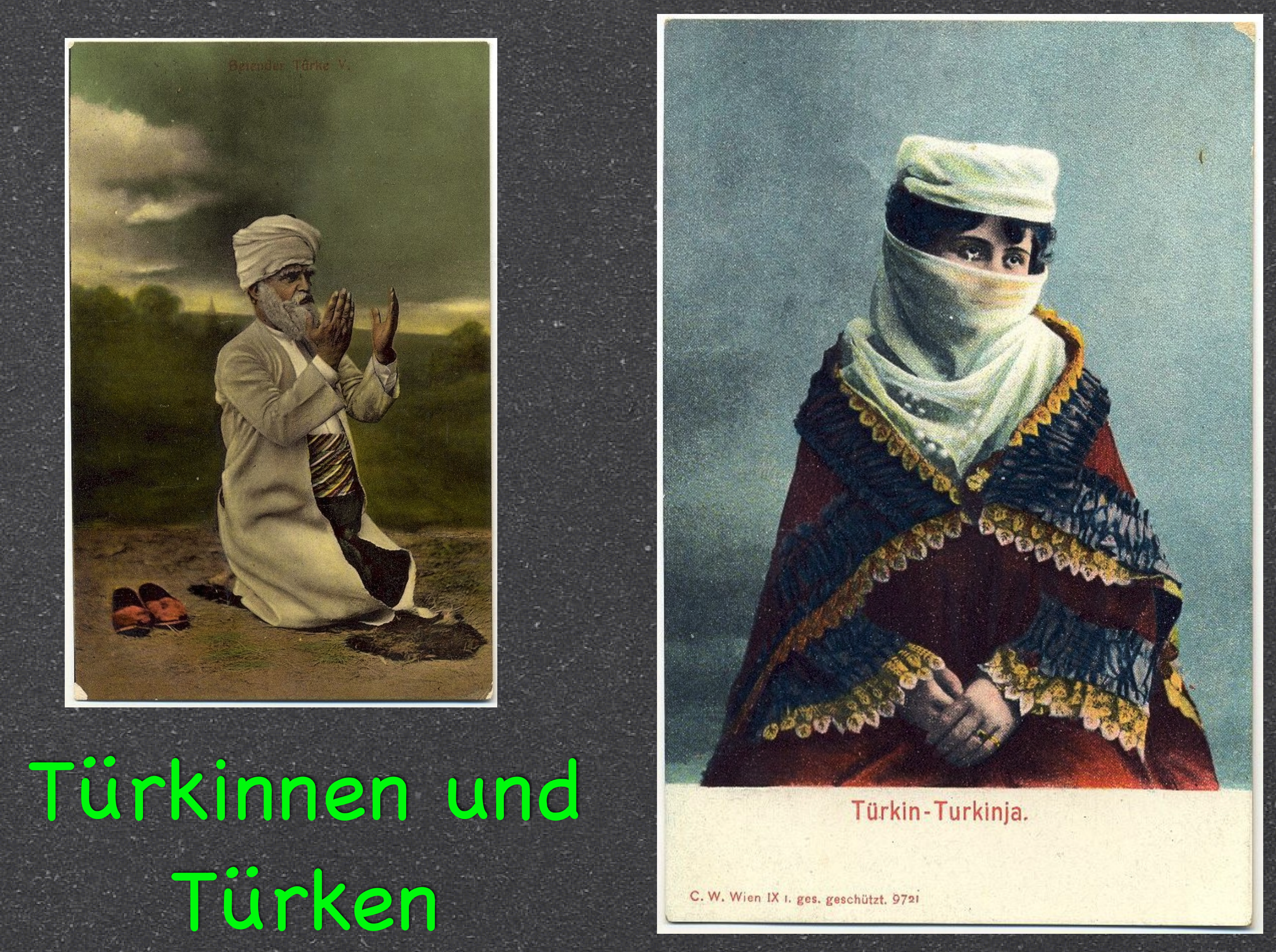


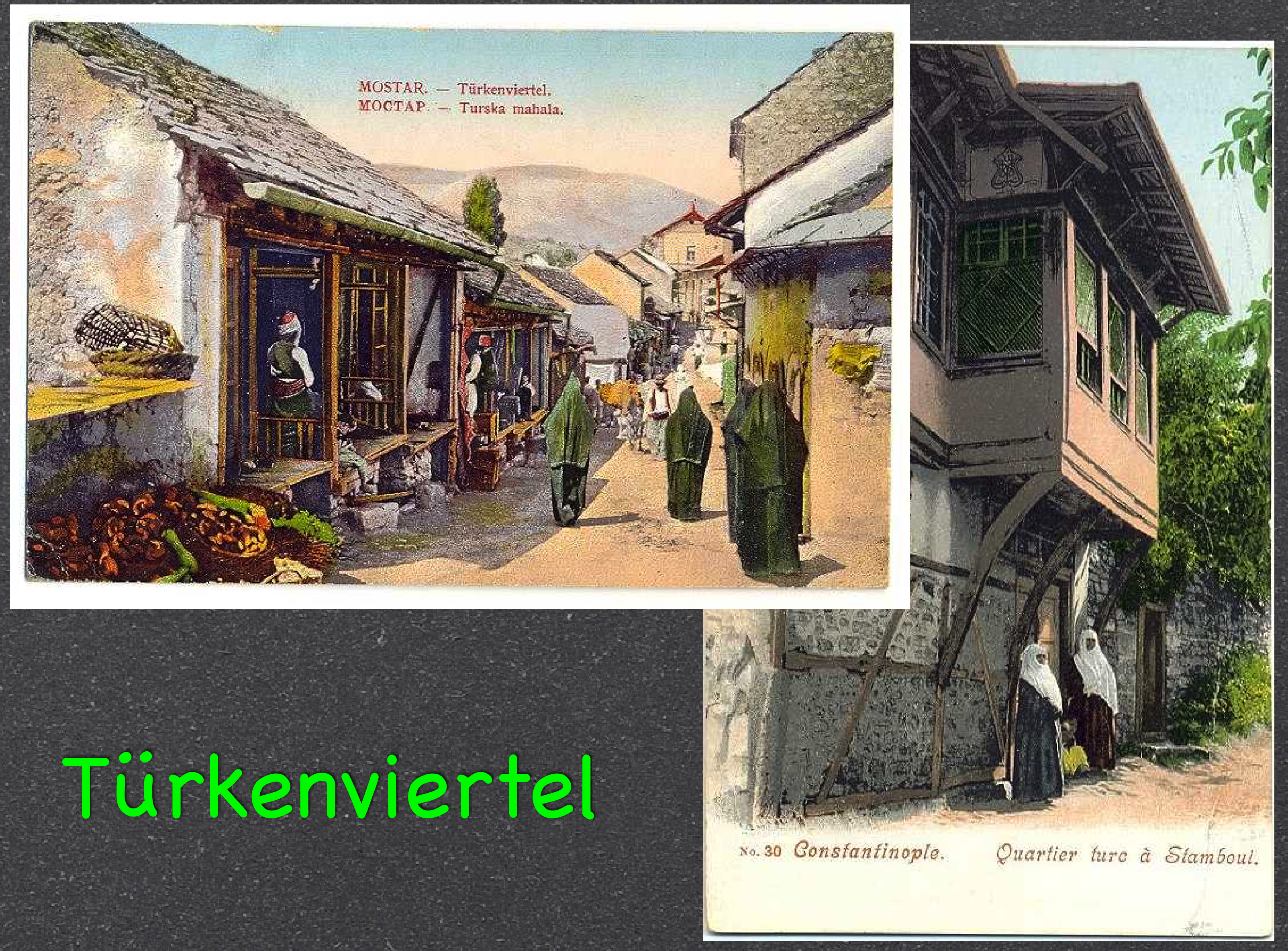




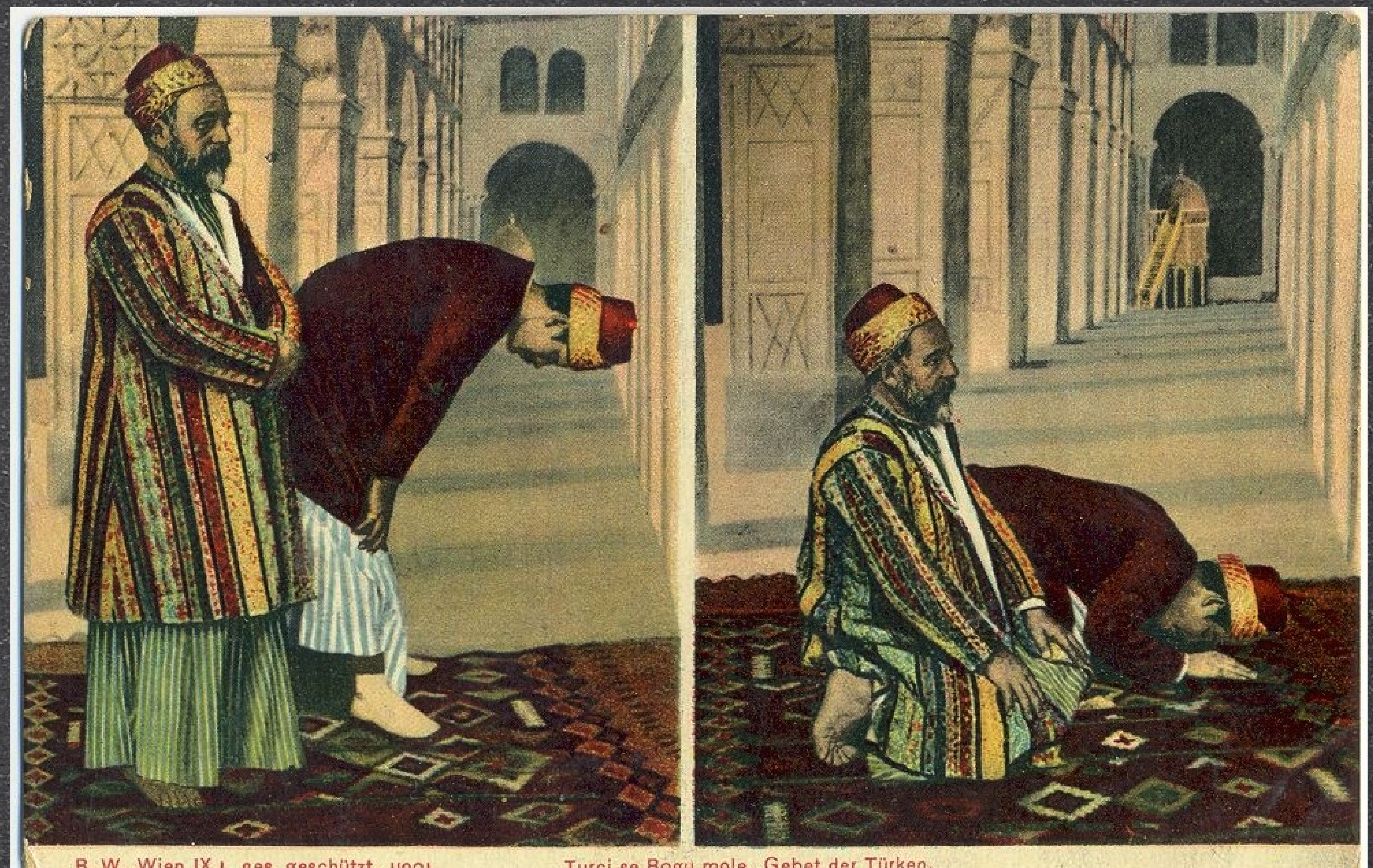

B. W. Wien IX I, ges, geschützt. 1100 I

Turci se Bogu mole. Gebet der Türken.

Bosnien + Türkei 


\section{Цuгaнckomo население на София}

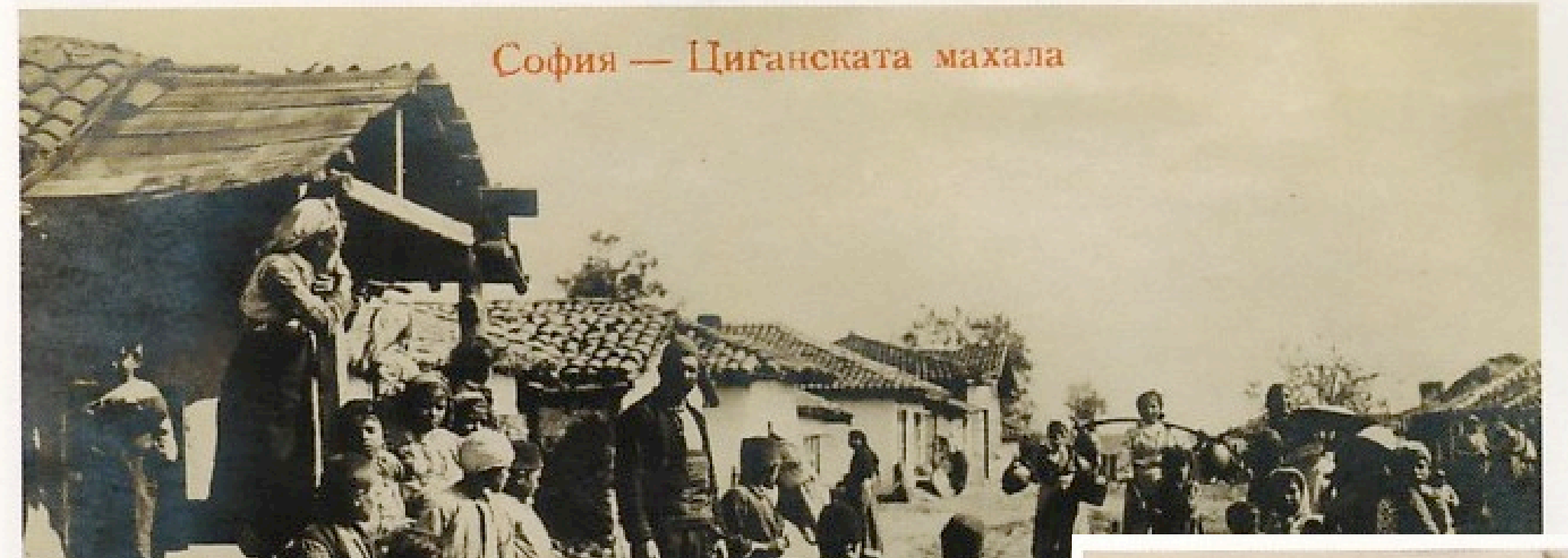

Monit.

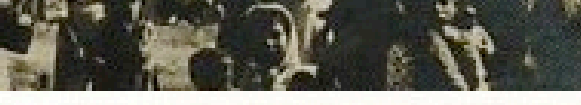
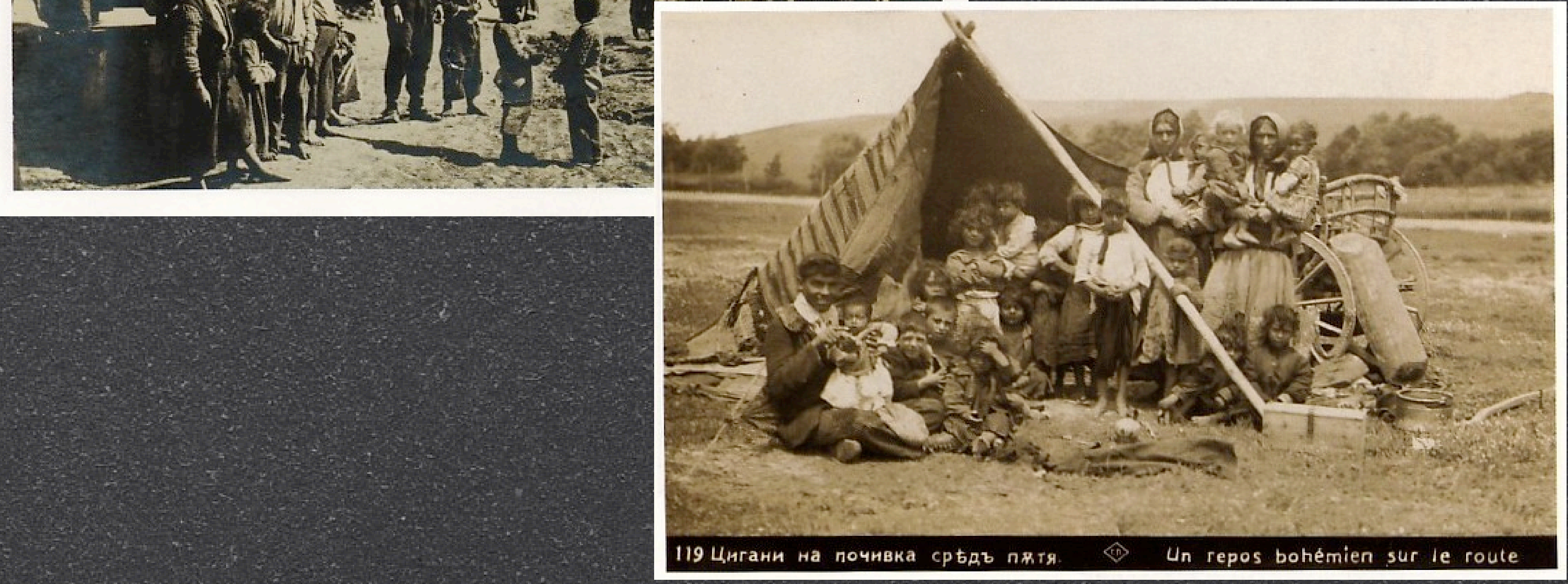

Bulgarien: Zigeuner 


\section{Postkarte.}

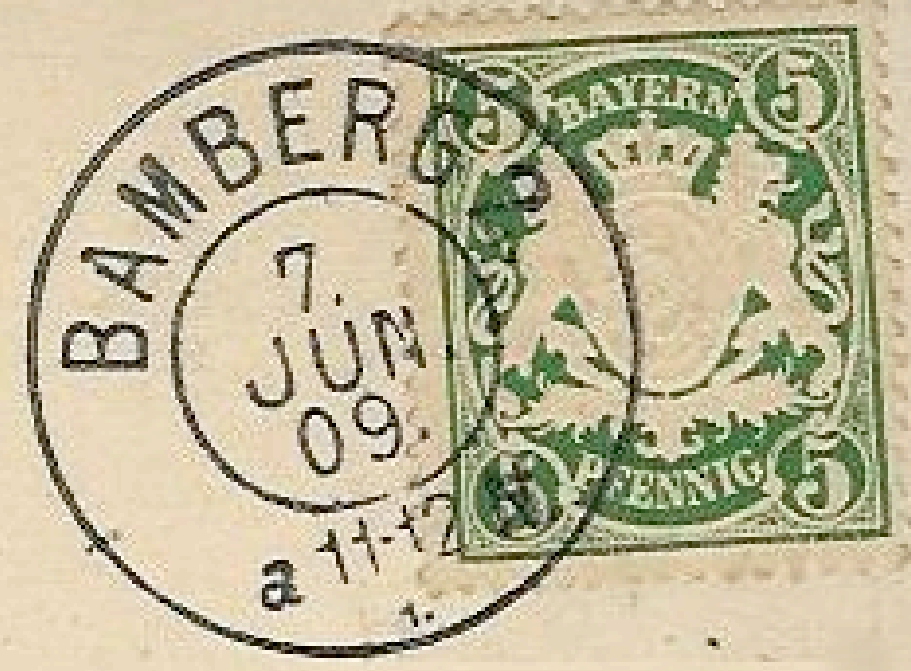

Bildseite

...politisch

...militärhistorisch 

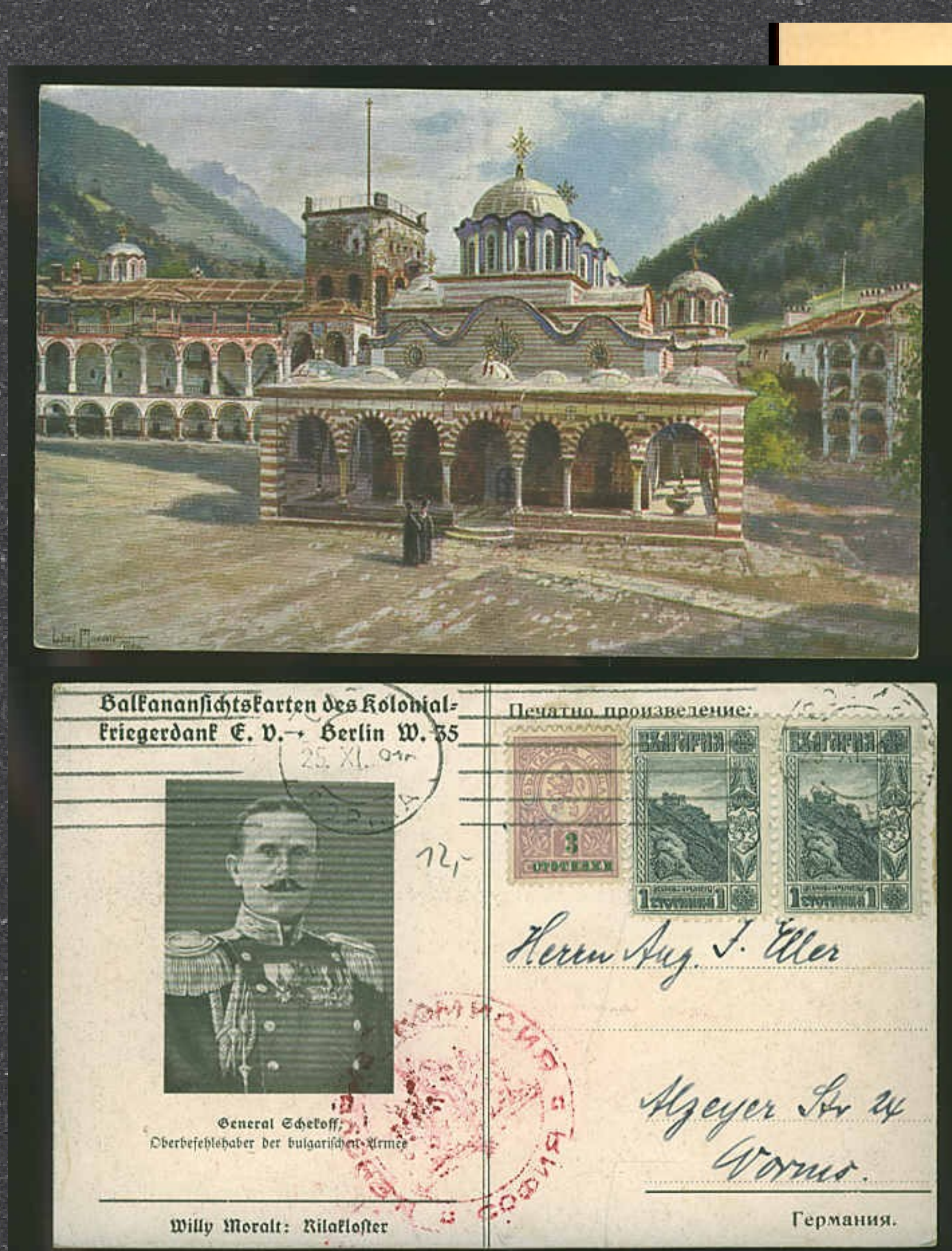
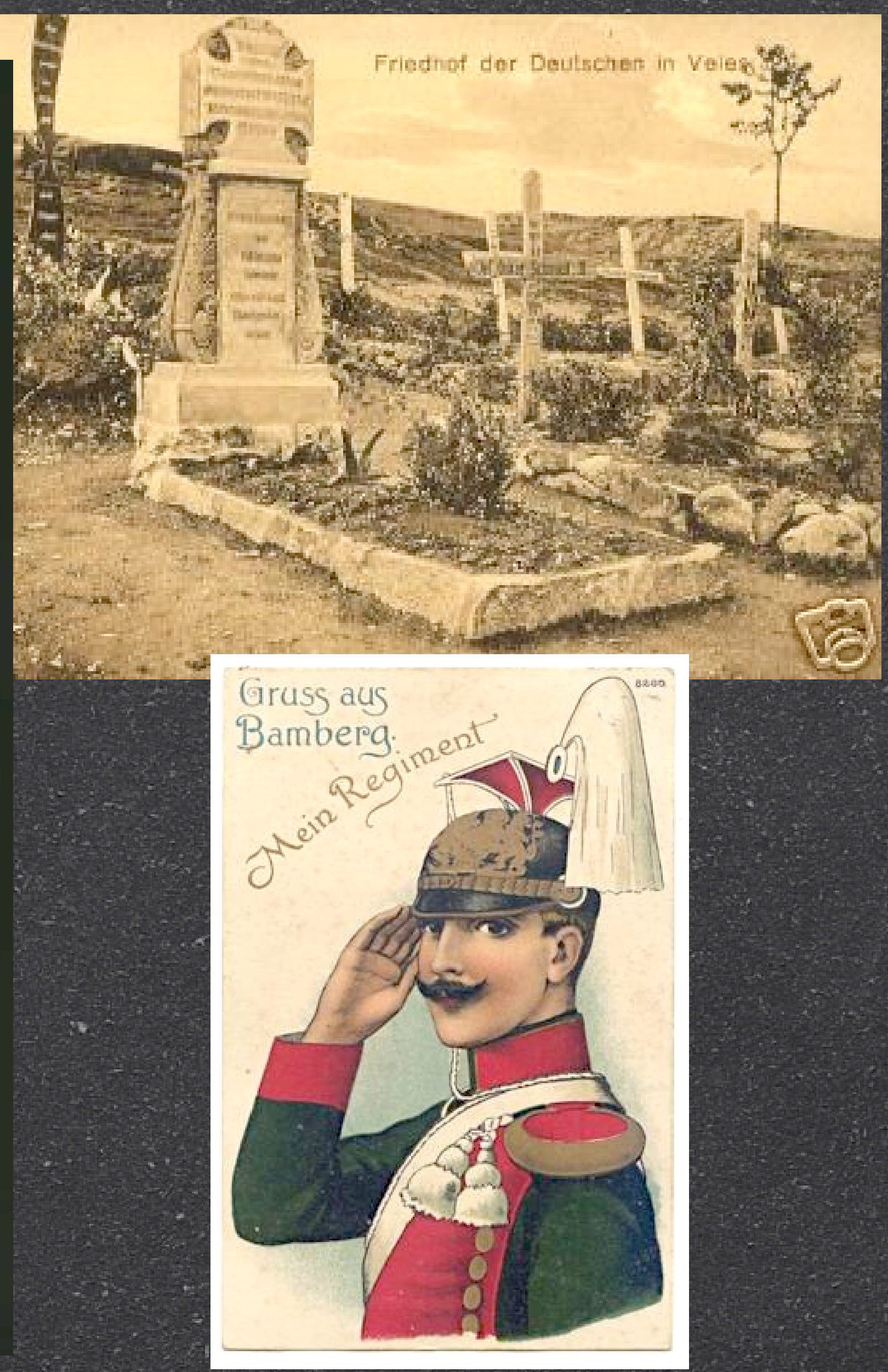


\section{Postkarte.}

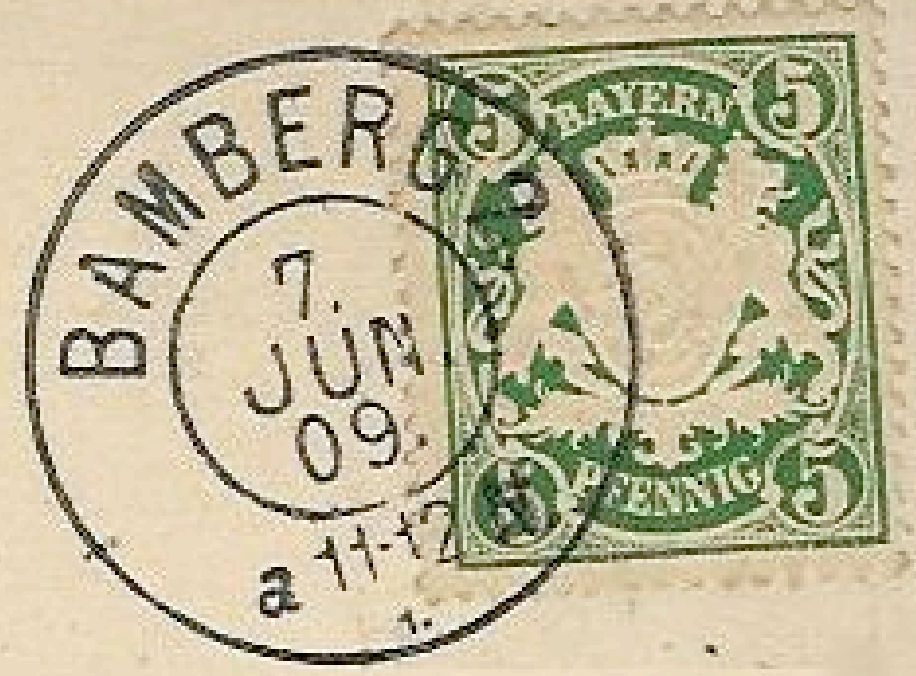

Postkarten

...linguistisch betrachtet 
Taufleunem P.13. Ohet. 192)

heine dielem!

Hinlaw drante fir tio

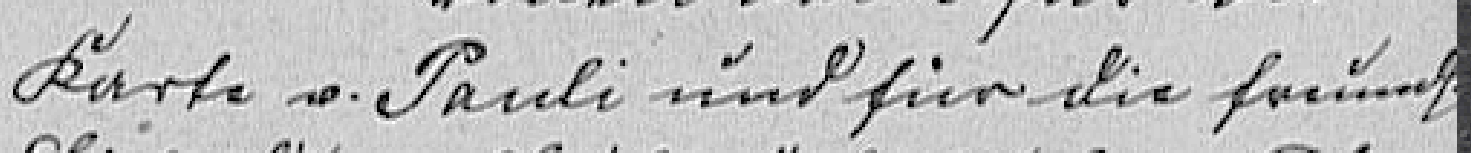

Giventing Girf giv befinfore ty

navira fafor ye

nlaiv if fuke.

bait to triping

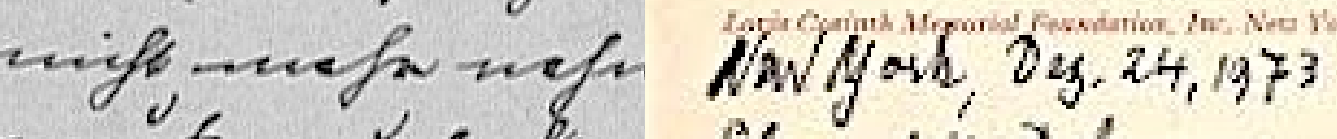

Textseiten...

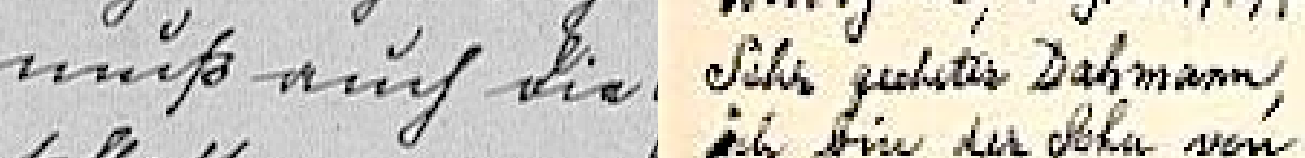

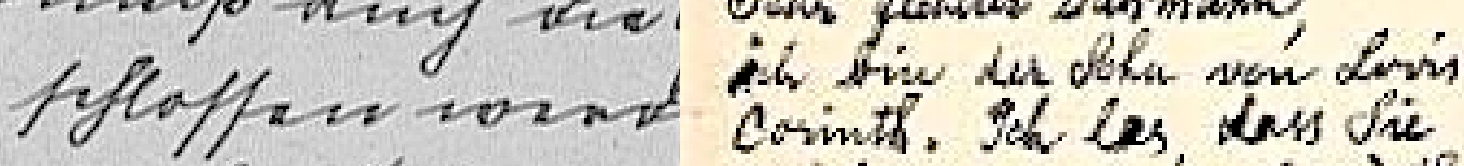

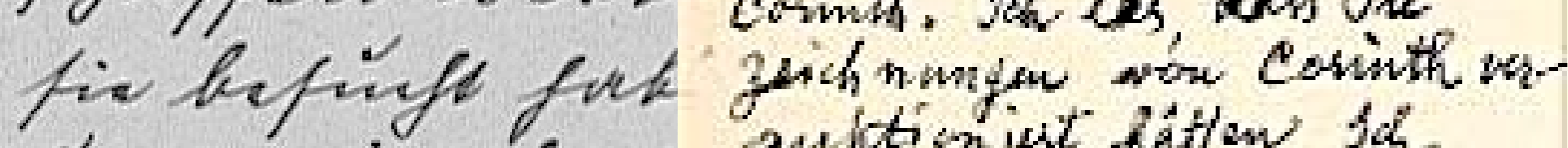

infuce ign dirf

auiction ist tattow. Sich

Fitte gein imsual sincas

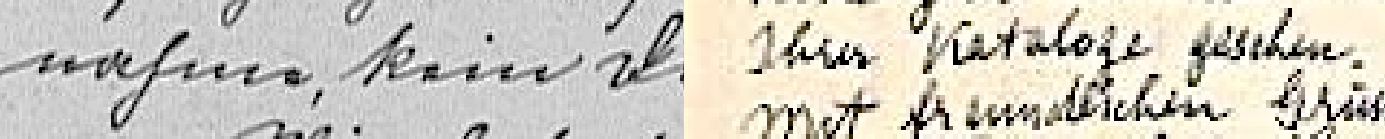

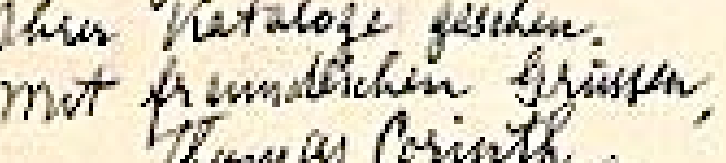

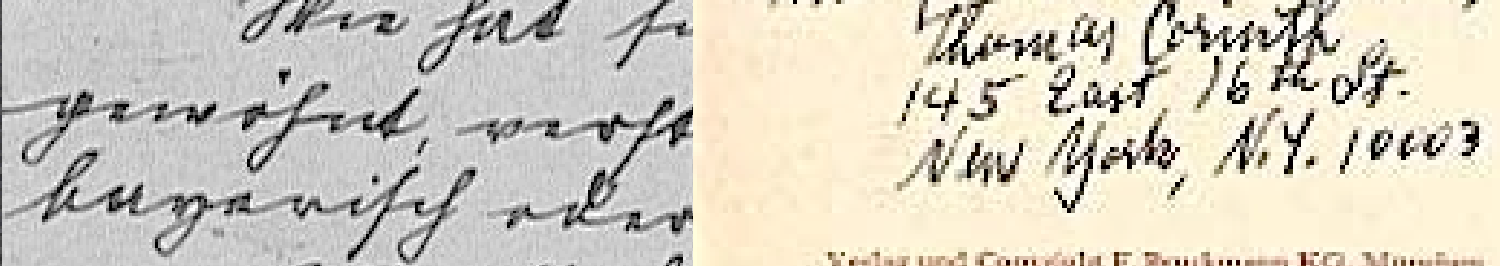

Hein thans-Xistis

I. be Ki da Finitag, 1.7. .42.
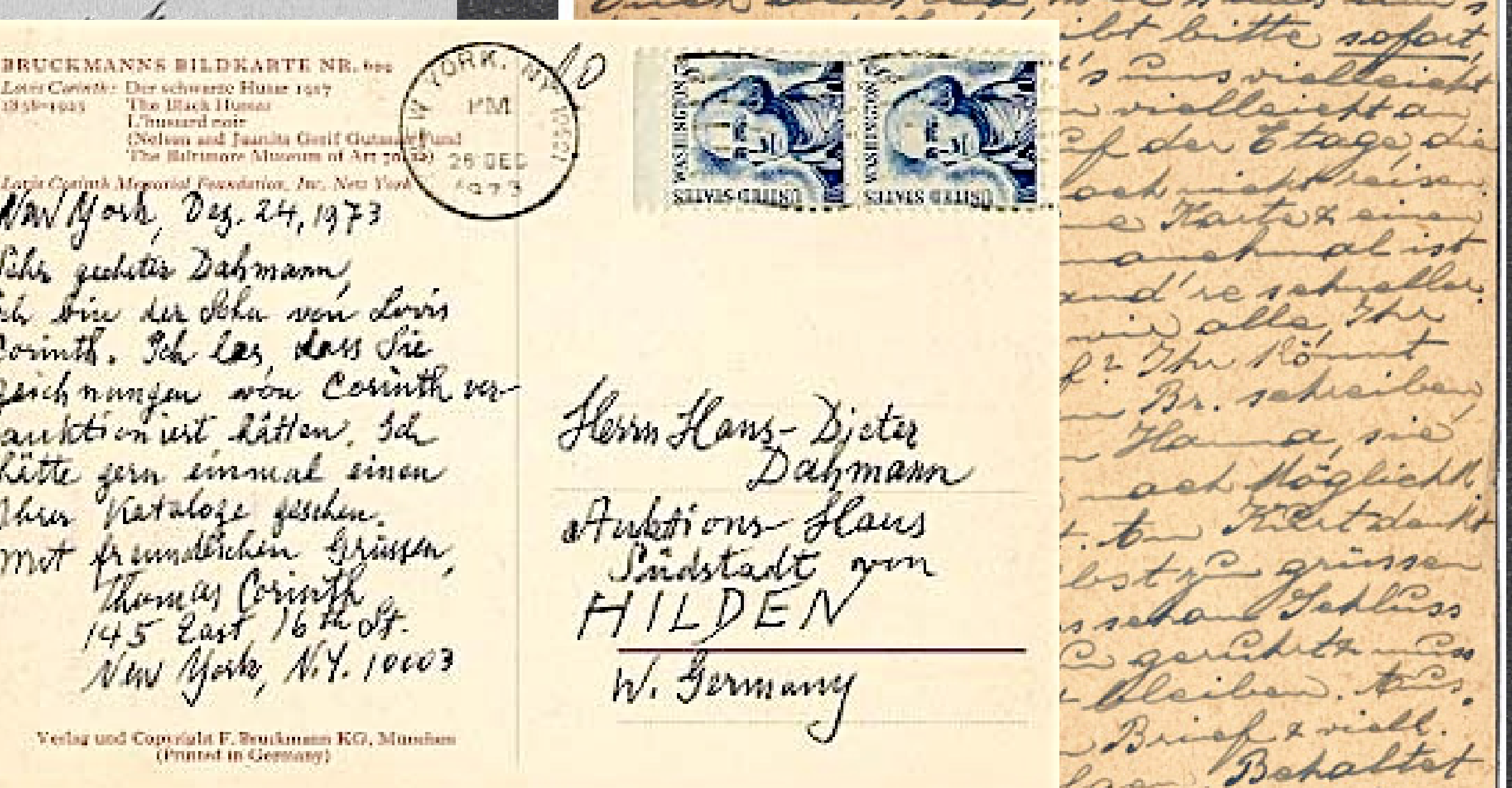

Lew lisbow tuma? Pan itulian

byomal ift firr nifte nufogit

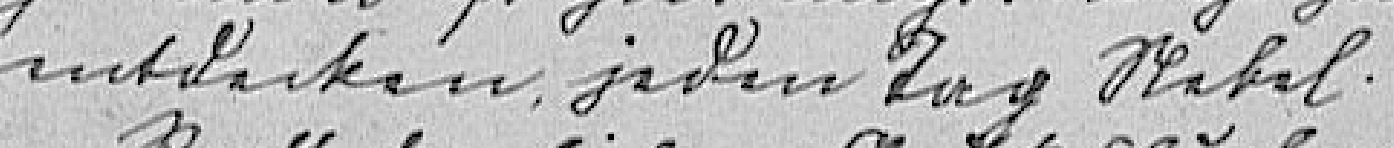

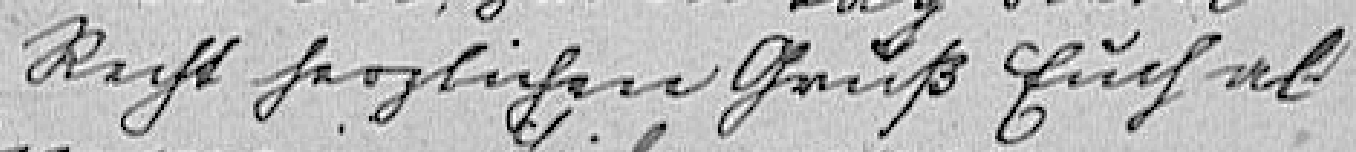

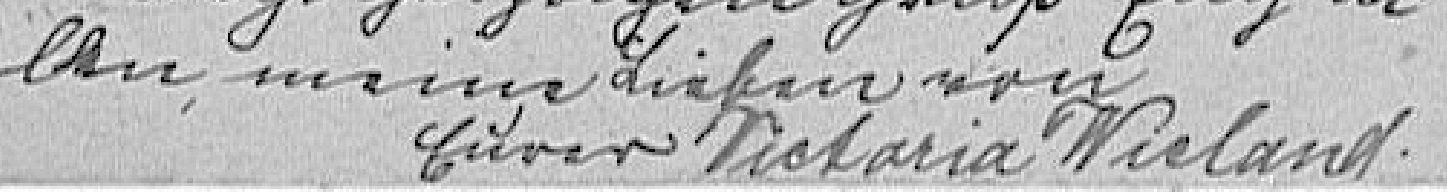

Aubtions-flaws

Shinstawt yom

W. Bumany

waen has

TSL2

Botaltit

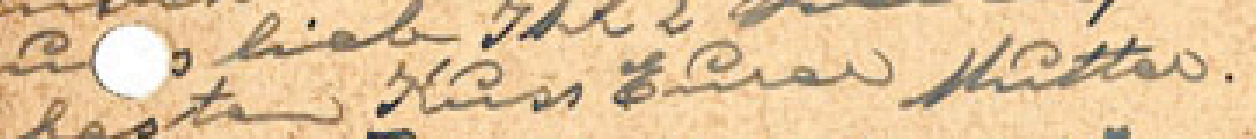

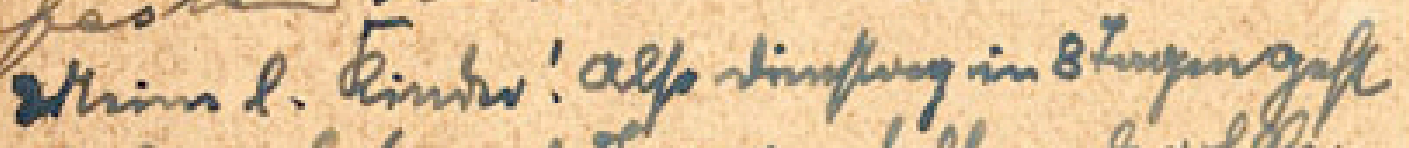

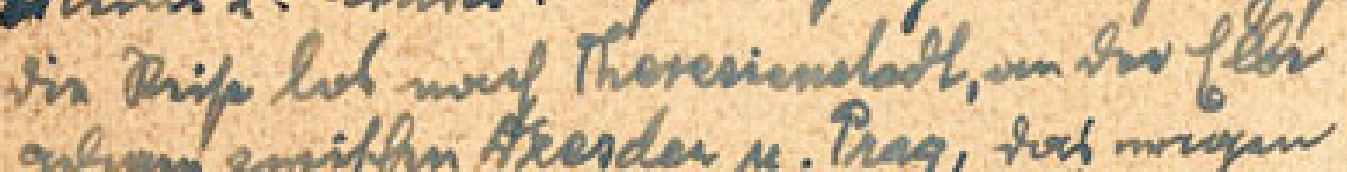

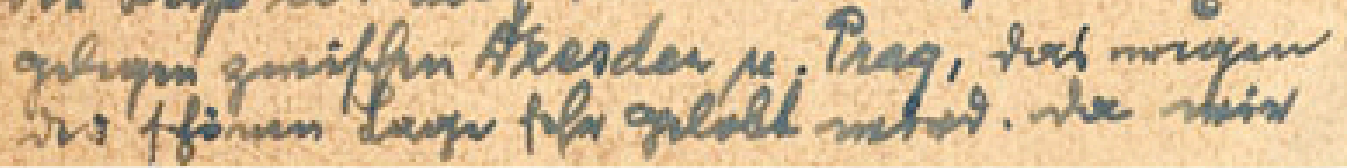




\section{Auch Text!}

Bosanski prodavači drva. Bosnischer j̧olzverkäufer.

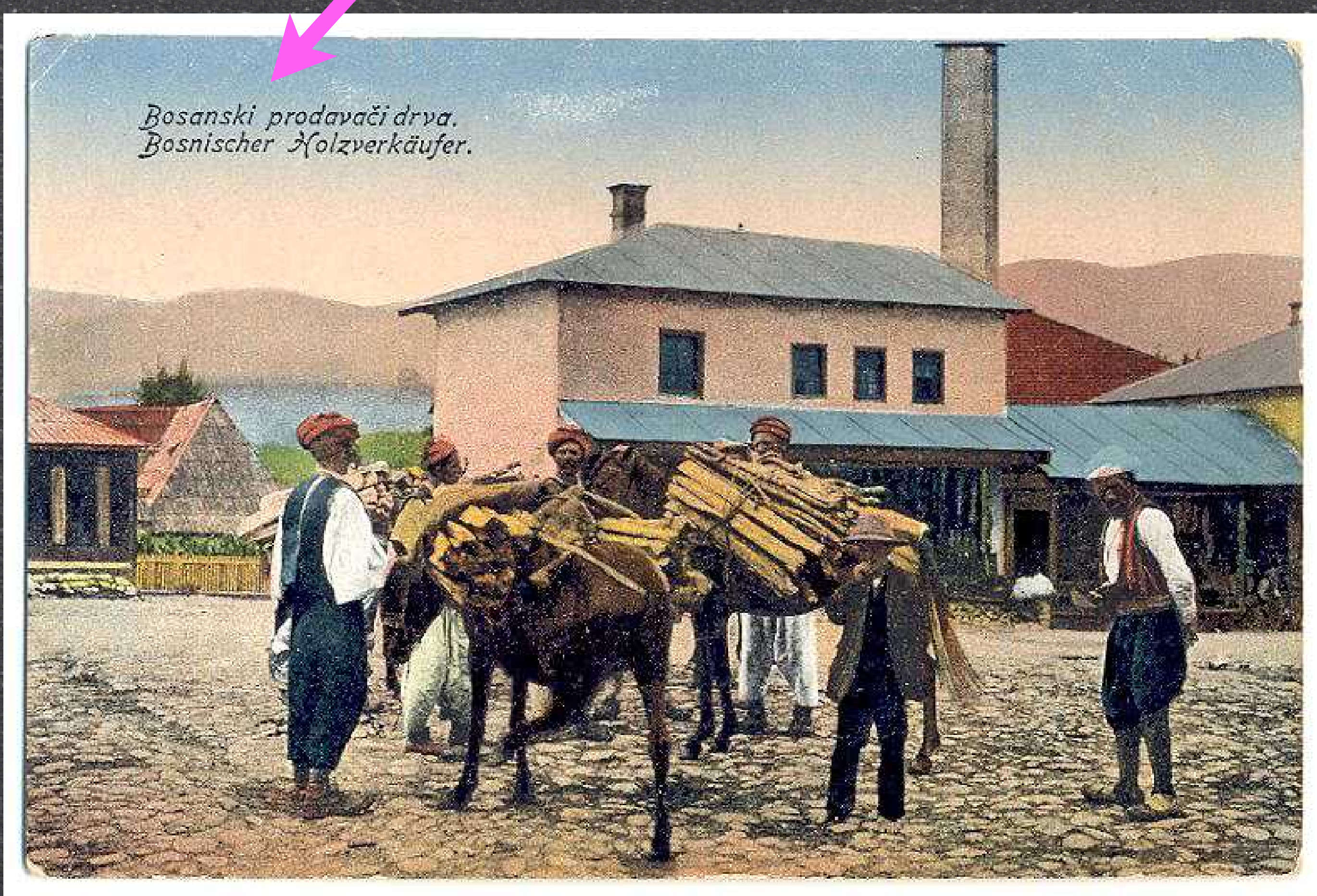




\section{kein Text}

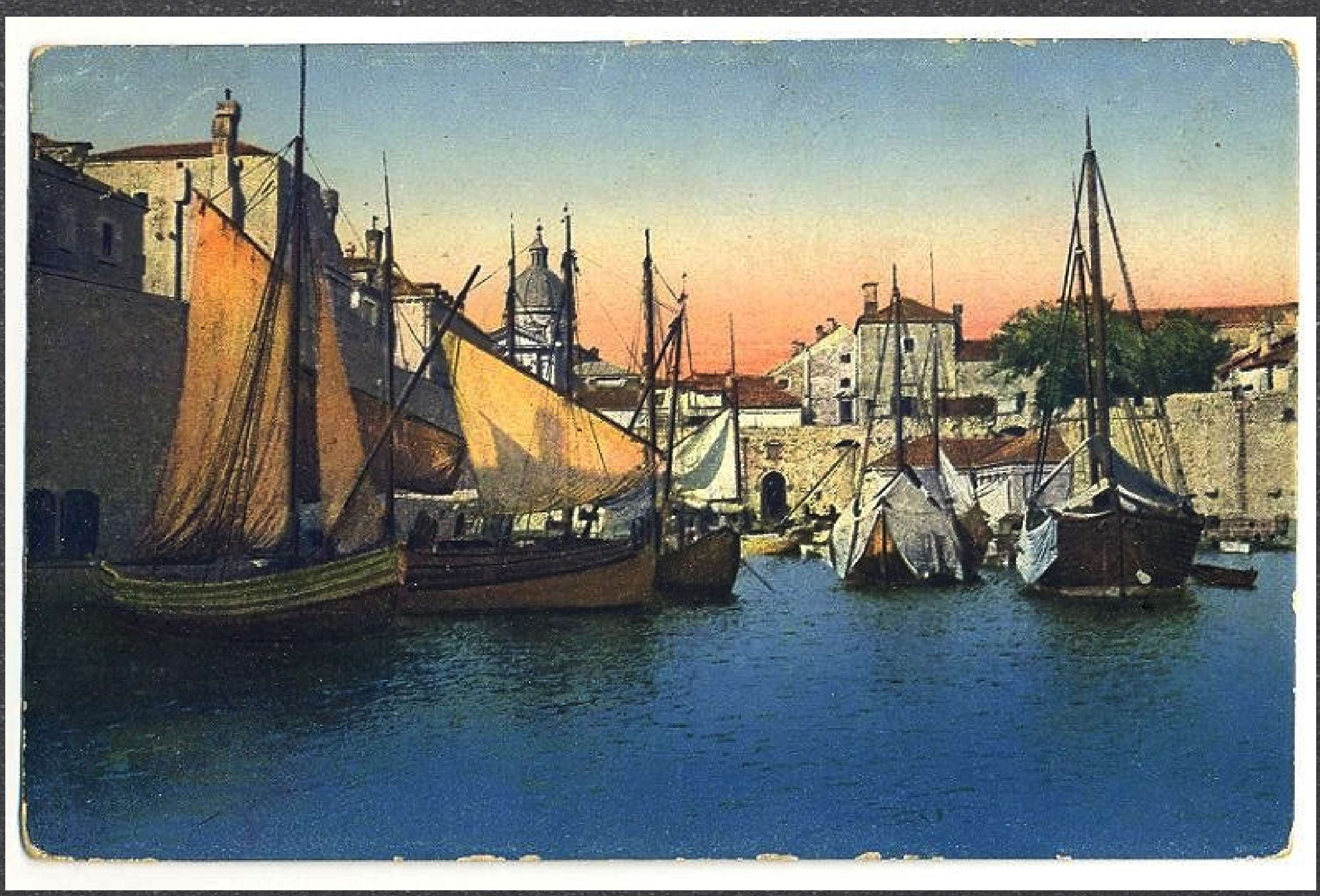




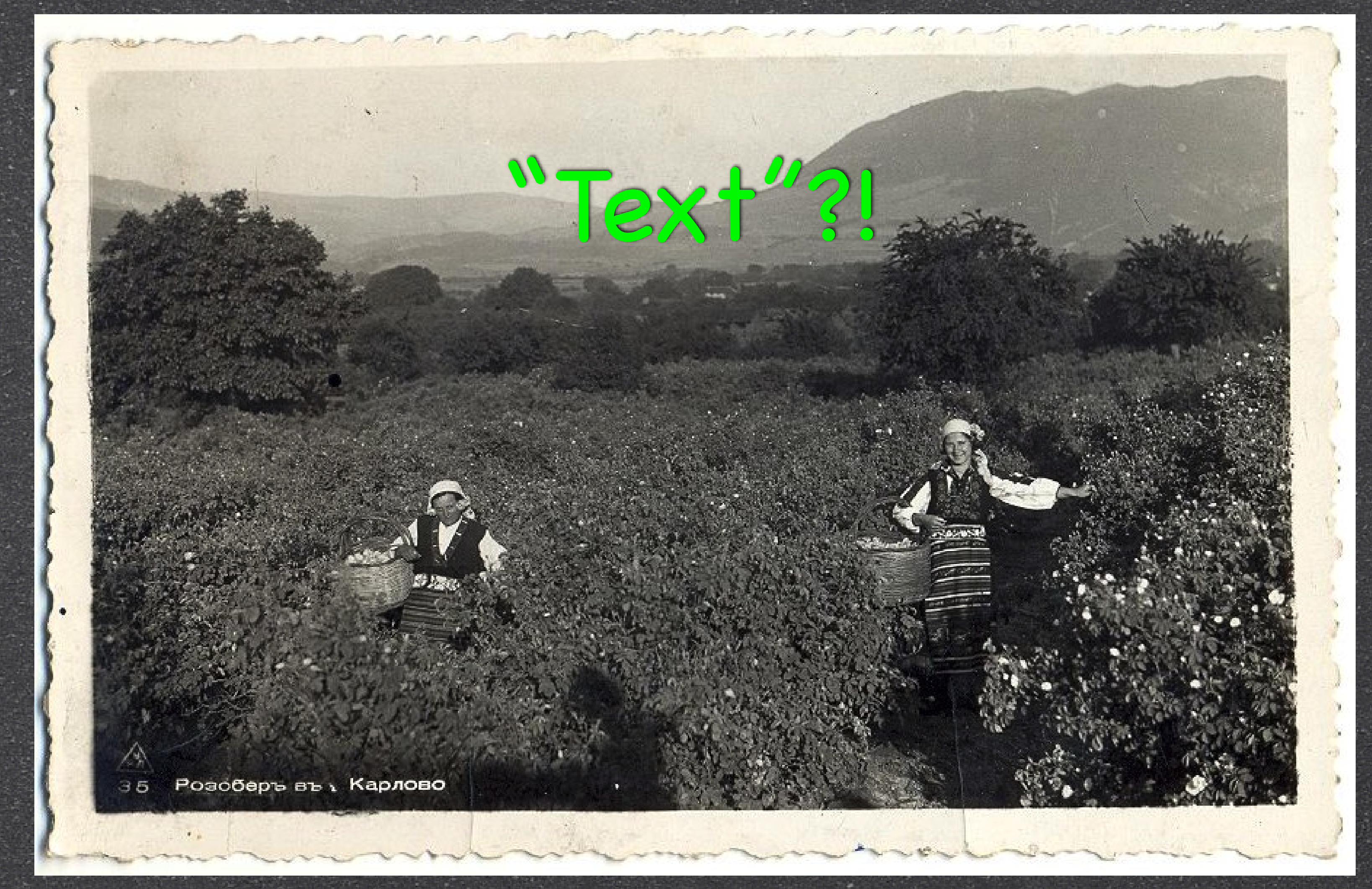

\section{"Розоберъ въ Карлово"}




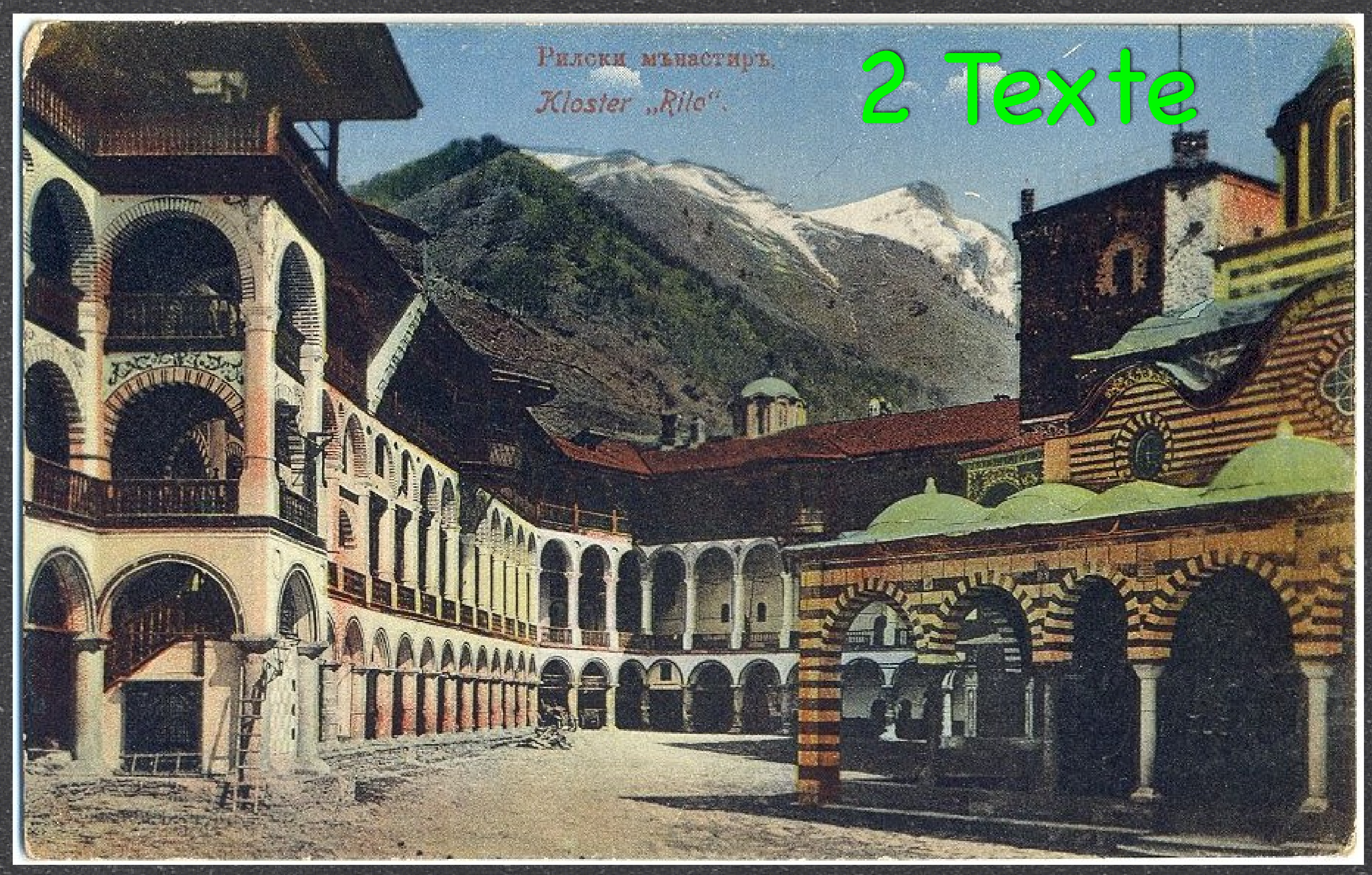

Рилски мънастиръ. Kloster "Rilo". 


$$
\text { Posthare }
$$

Untersuchungsobjekt: - Der Text auf der Bildseite 


\section{Postkarte.}

Untersuchungsobjekt:

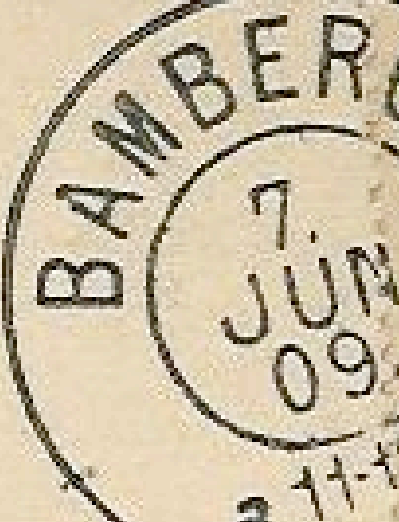

Q? 6 Nin?

- Der Text auf der Bildseite

- histor. Balkan-Postkarten

(1. Hälfte 20. Jh.) 


\section{Postkarte.}

Korpus

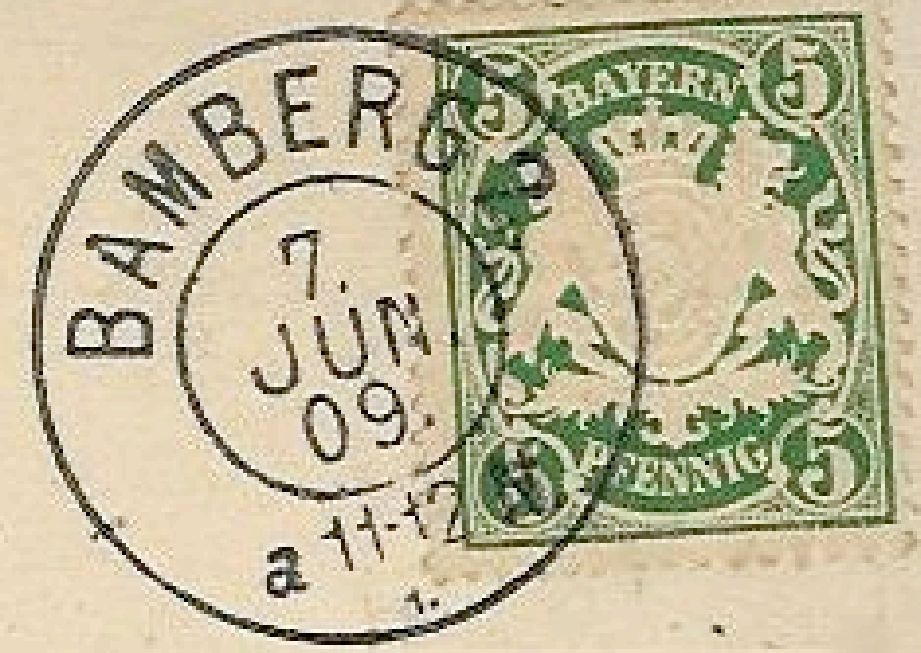

- ca. 600 Balkan-Postkarten

als Datenbank

- "Nepoznatata Sofija", Sofia

2005; >900 Postkarten 


\section{Postkarte.}

Datenbank

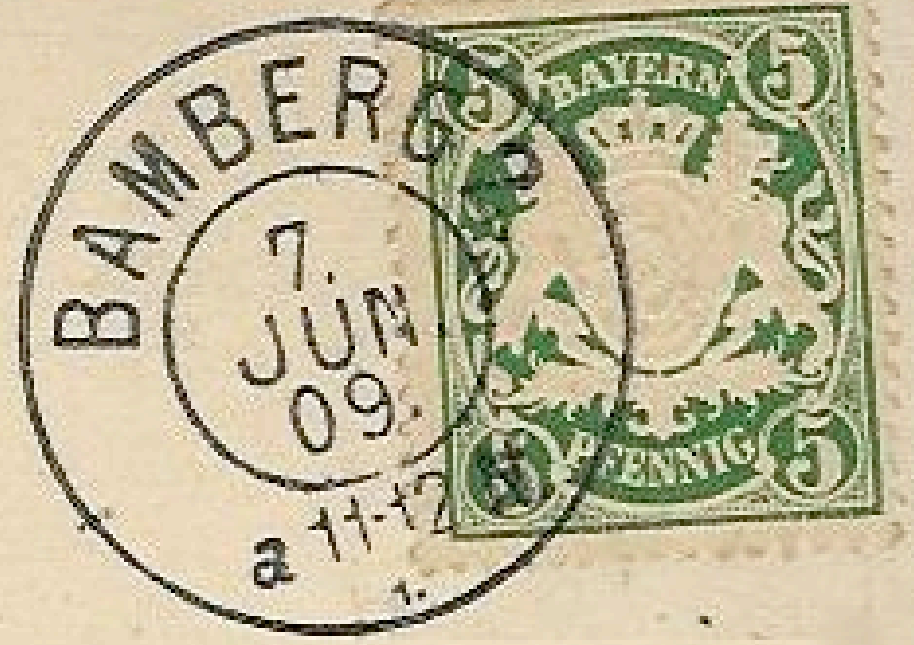

- ca. 600 Balkan-Postkarten

- davon 322 Bulgarien

- Herkunft: ebay 


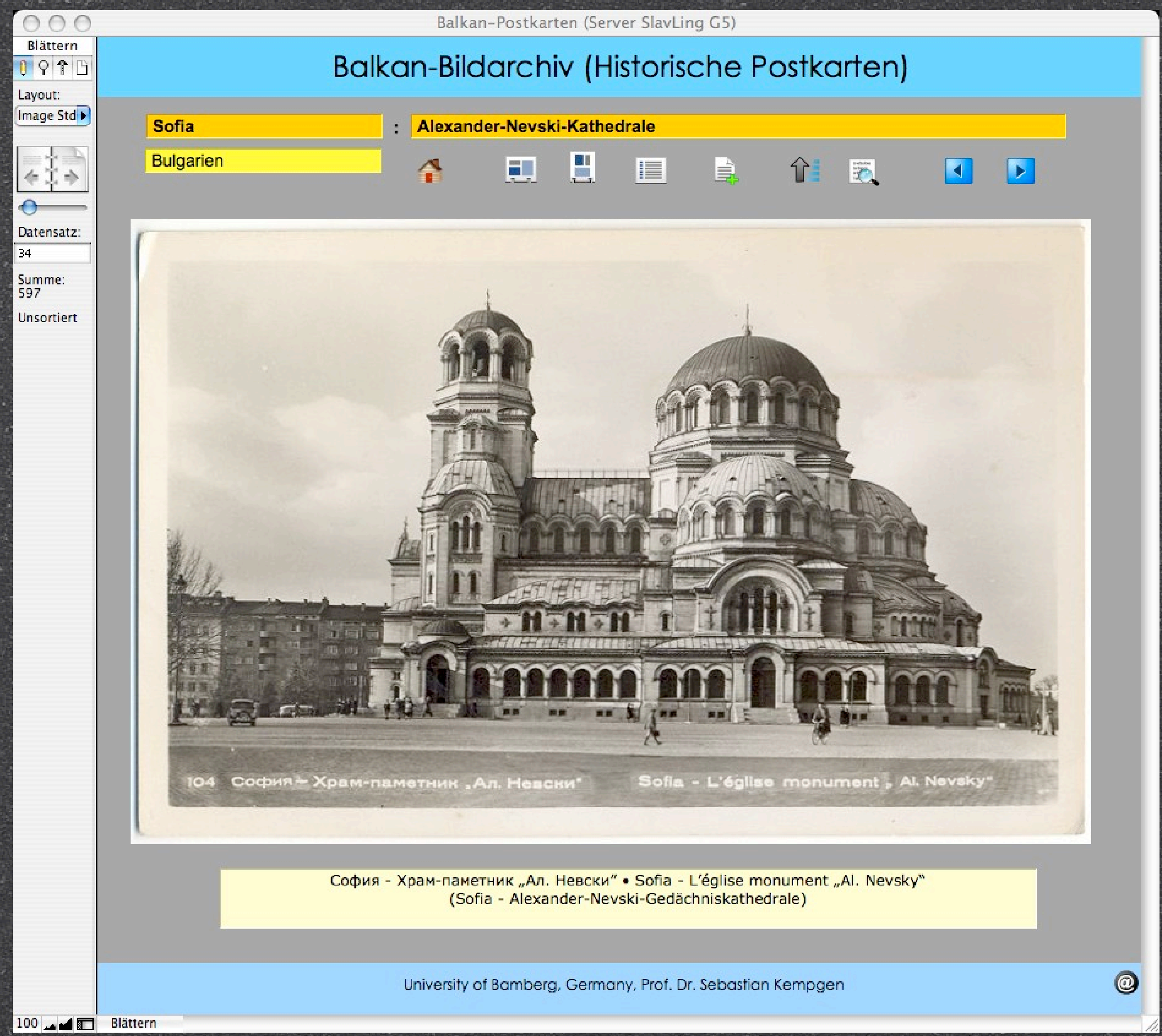




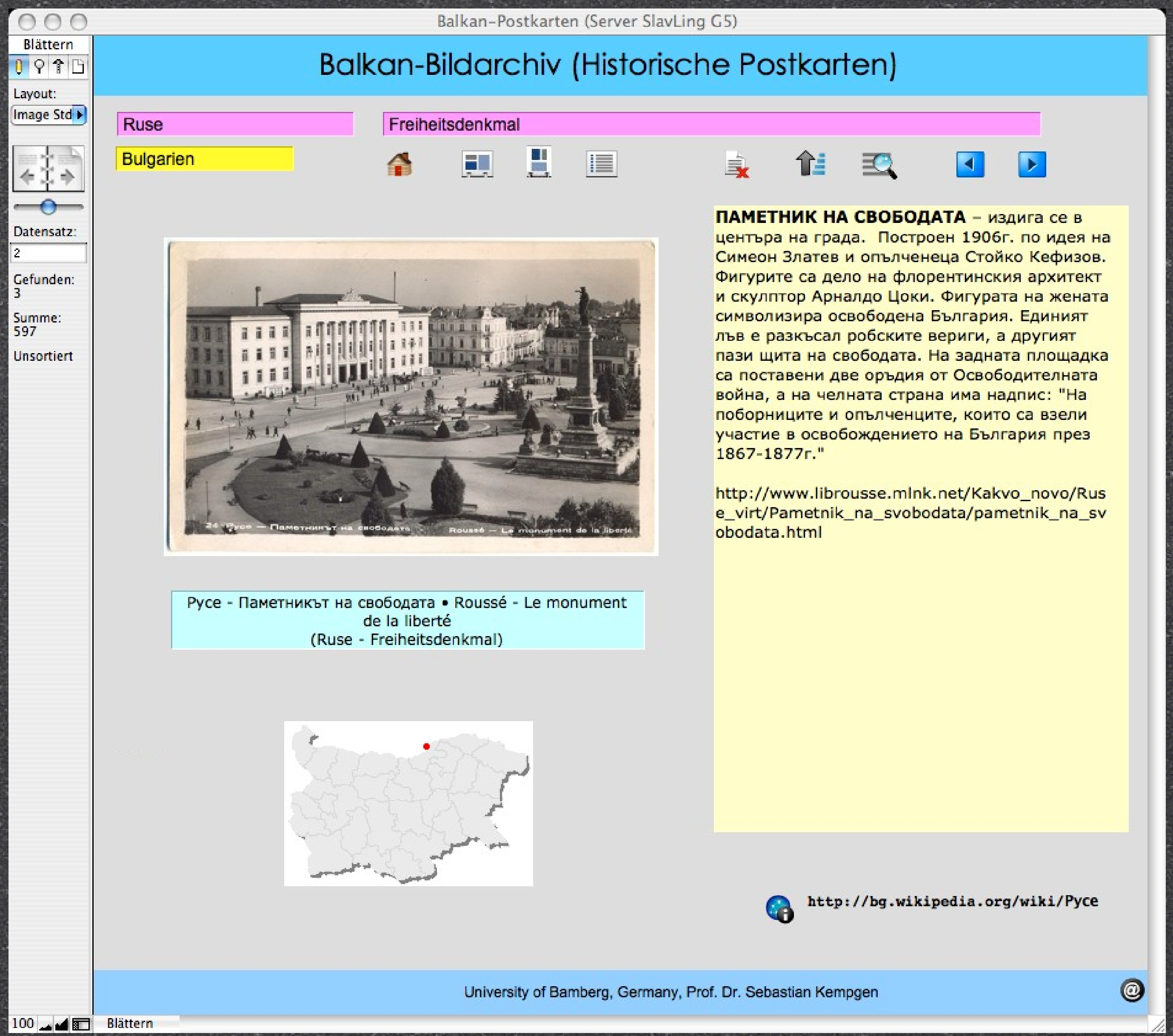




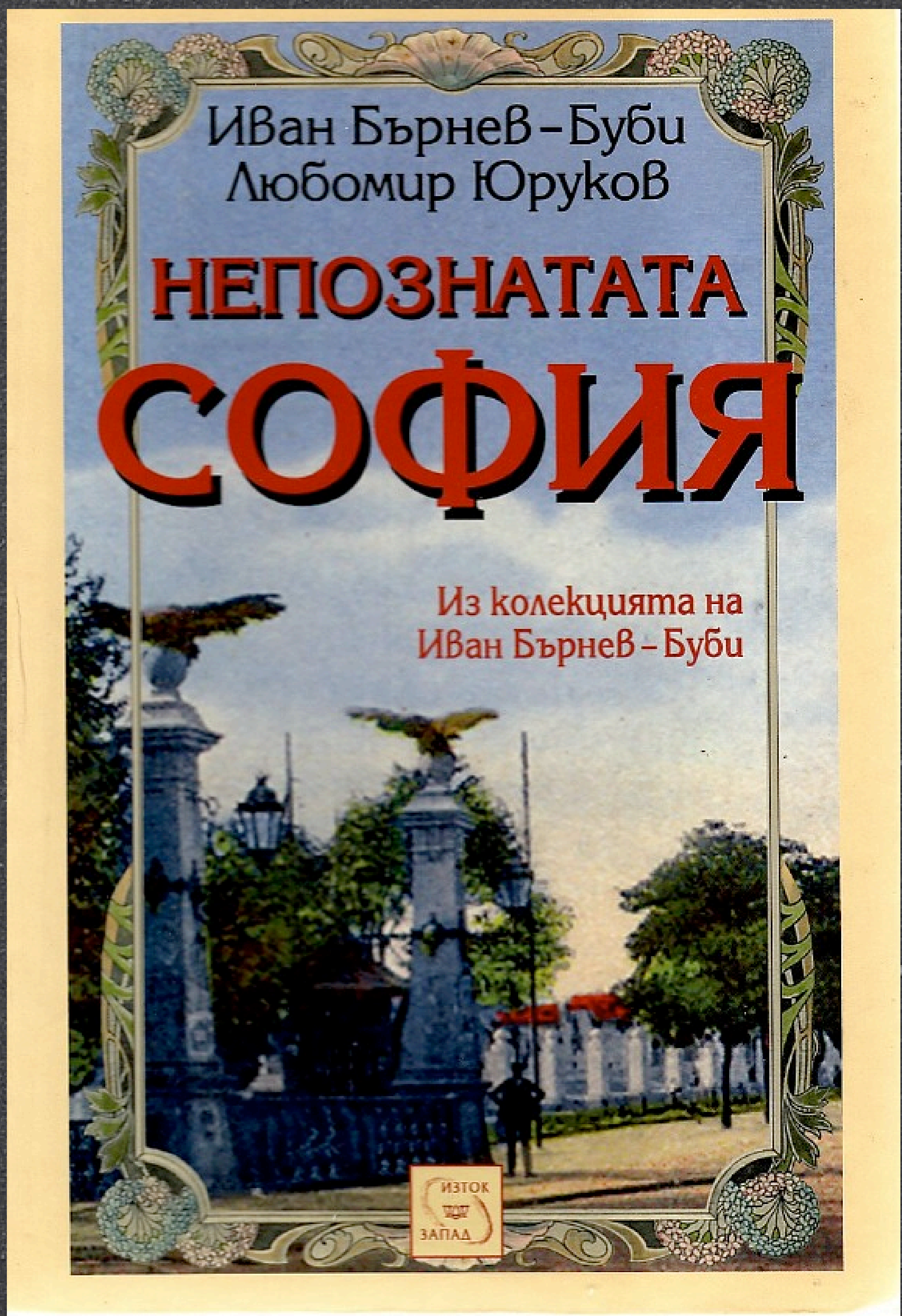

$$
\begin{aligned}
& \text { "Nepoznatata } \\
& \text { Sofija", Sofia } \\
& 2005 ;>900 \\
& \text { Postkarten }
\end{aligned}
$$




\section{Postkarte.}

Hintergrund:

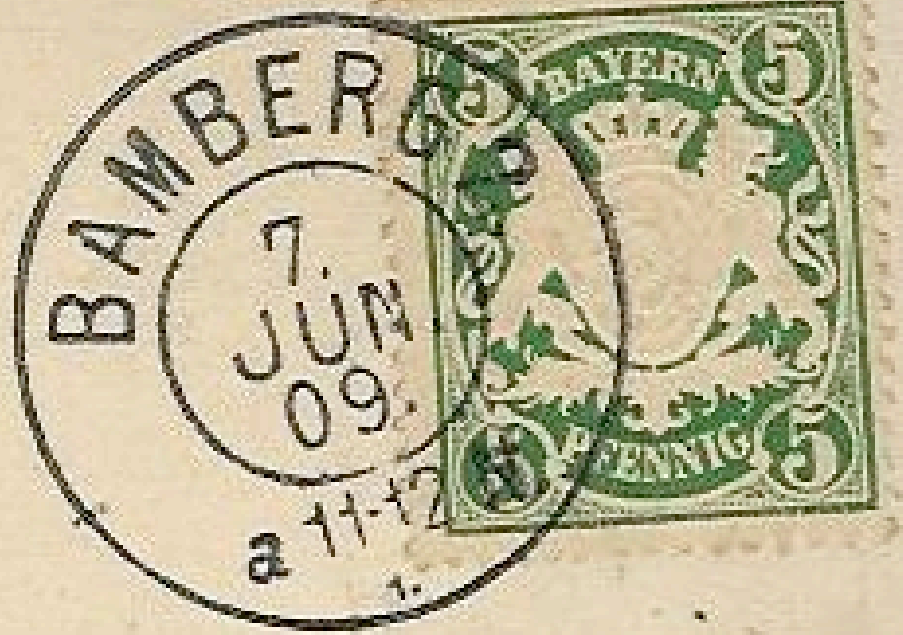

Projekt (2005-2007)

"Bildarchiv Südslawische Kulturgeschichte" 


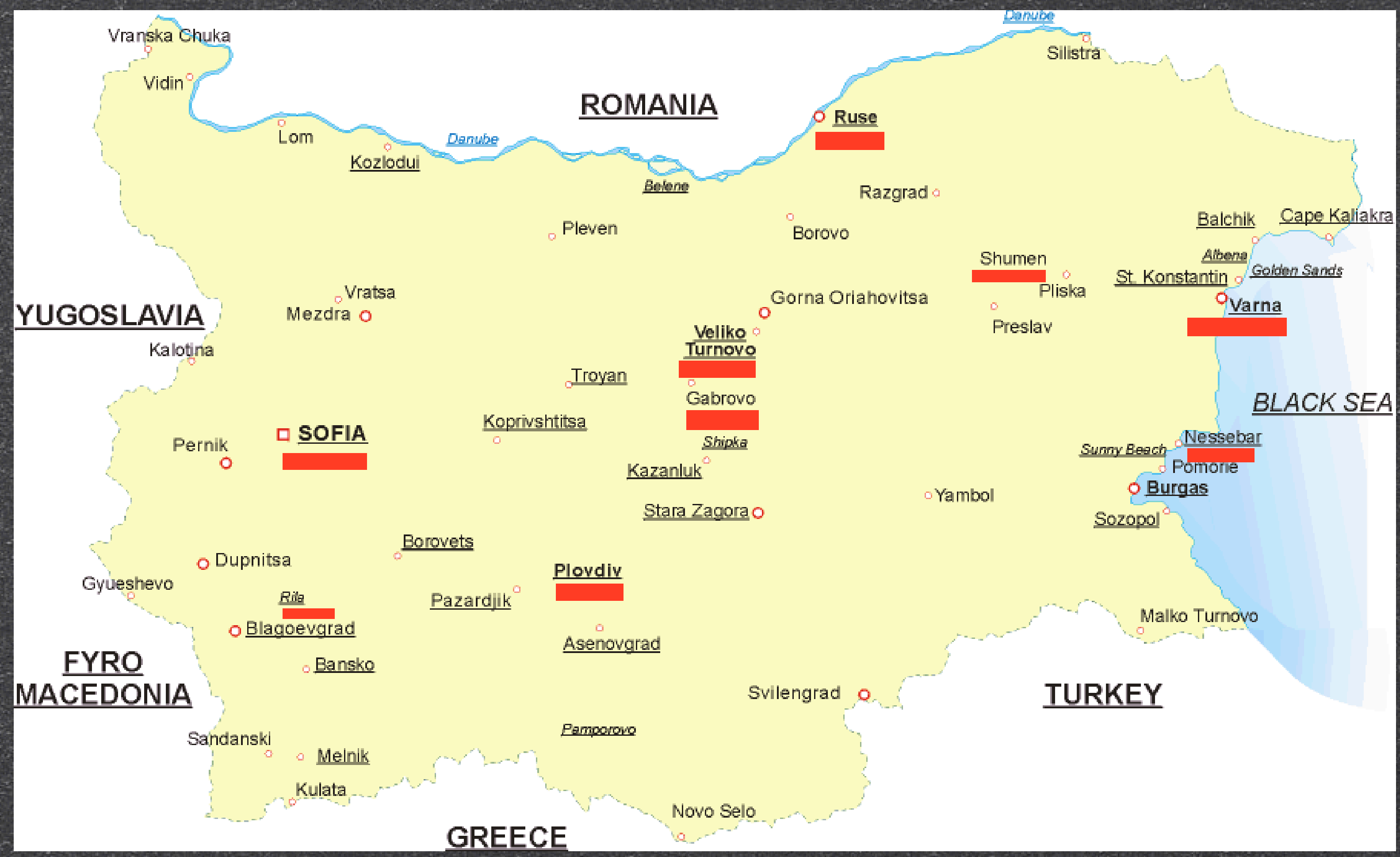




\section{Hit Nr. 1: Varna und seine Badeanstalt}

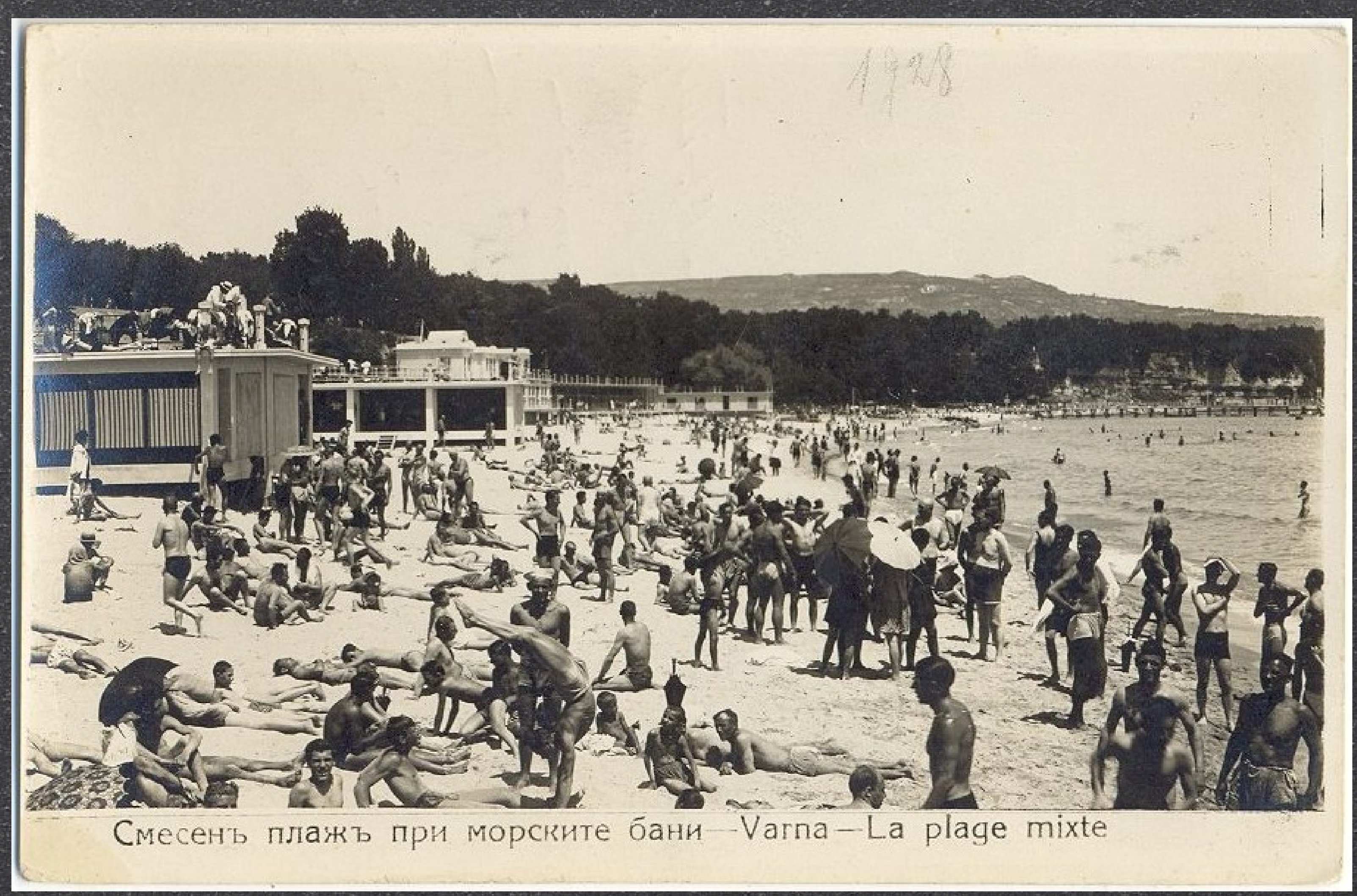




\section{Hit Nr. 2: Sofia}

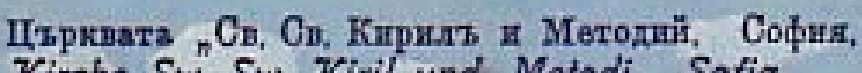

Kirche Sw. Sw. Kiril und Metodi. Sofia.

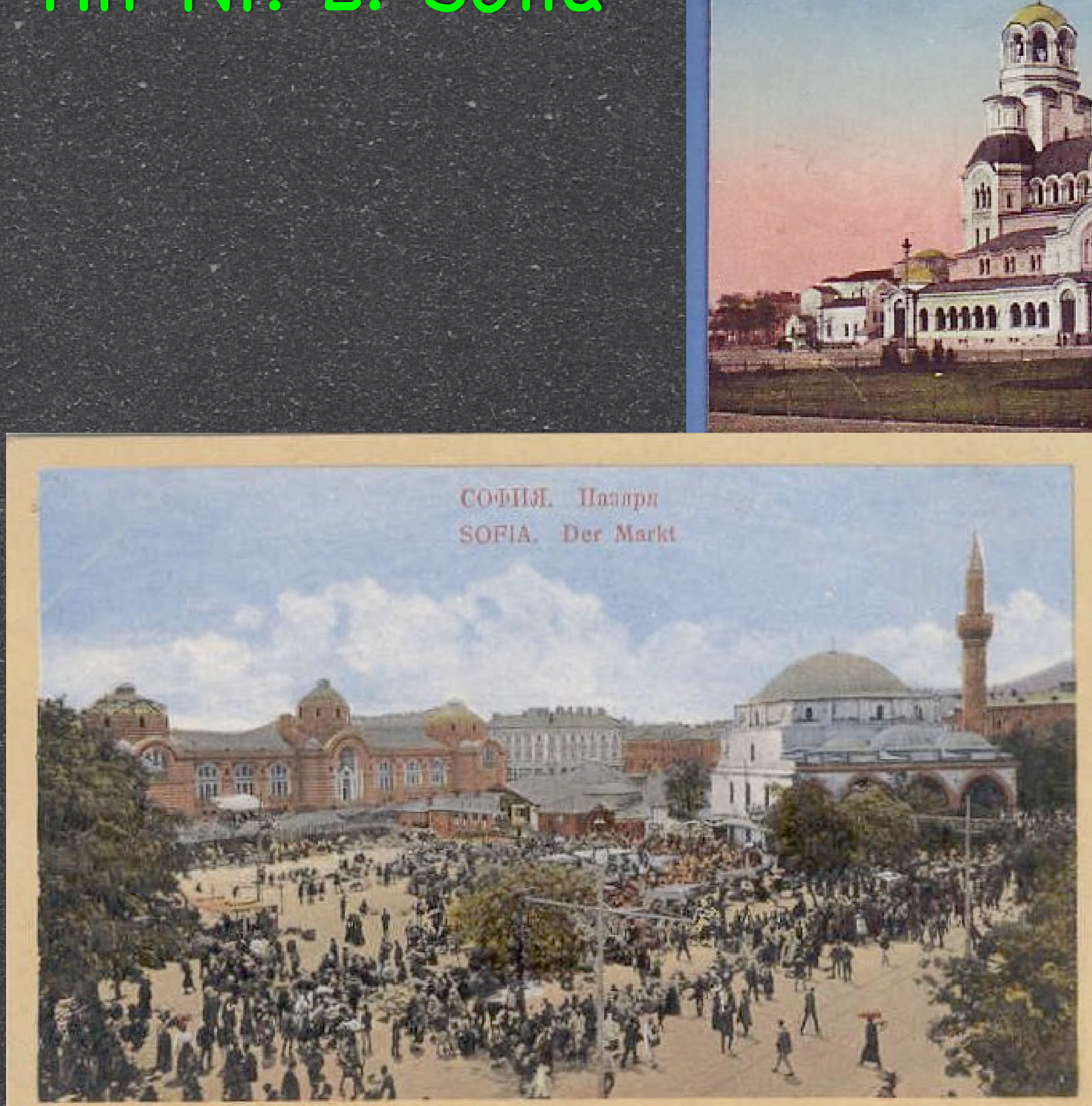




\section{Postkarte.}

Histor. Hintergrund:

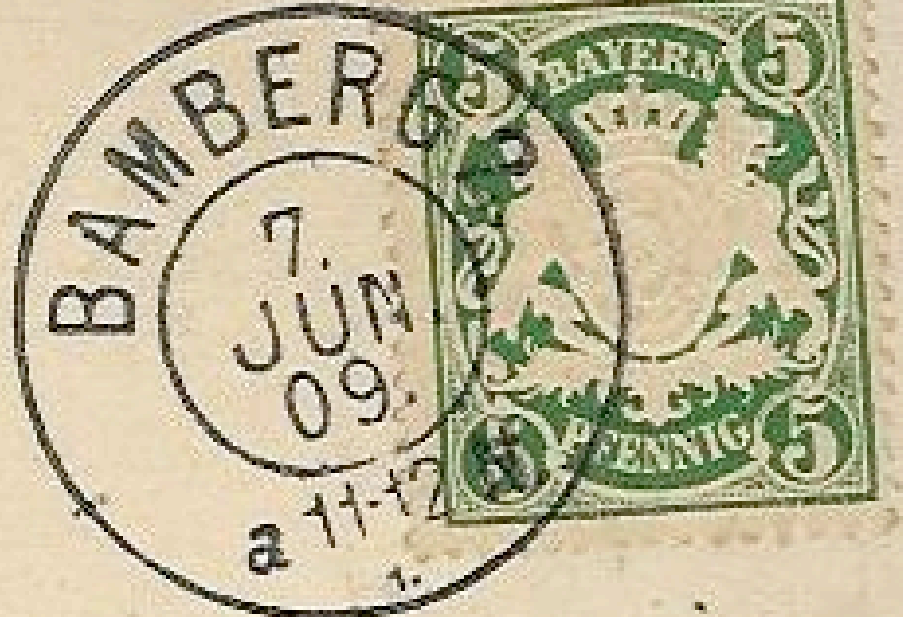

- Befreiung Bulg. 1877/78

- Postkarten ab Jh.-Wende 


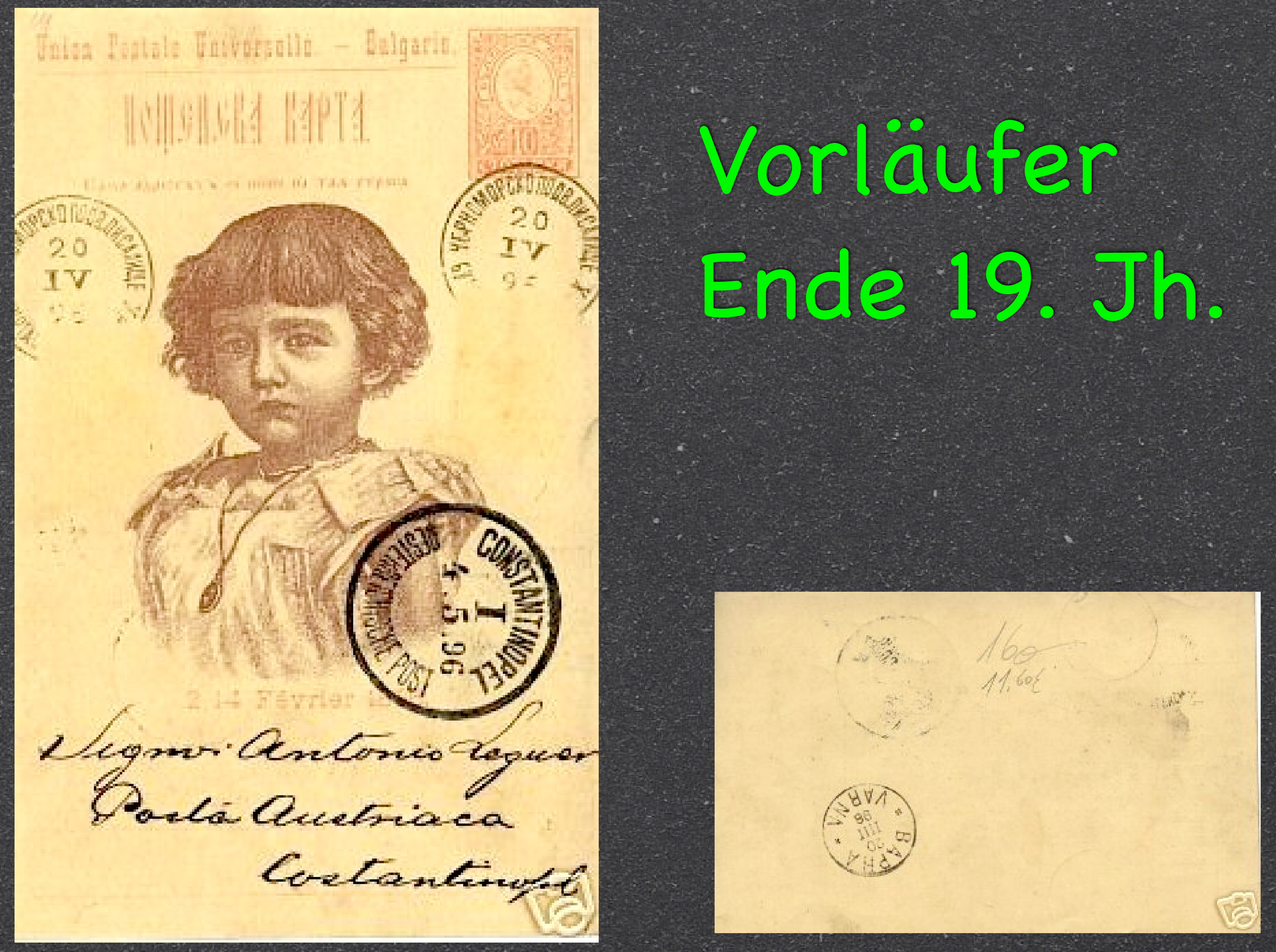




\section{Postkarte.}

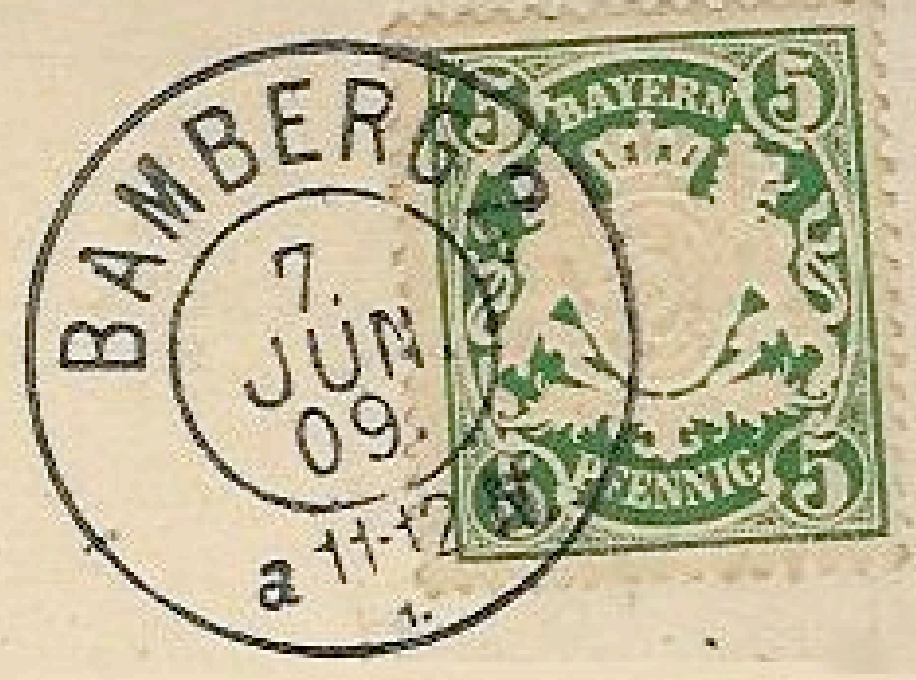

Ergebnisse 


\section{Postkarte.}

\section{Hauptsprachen:}

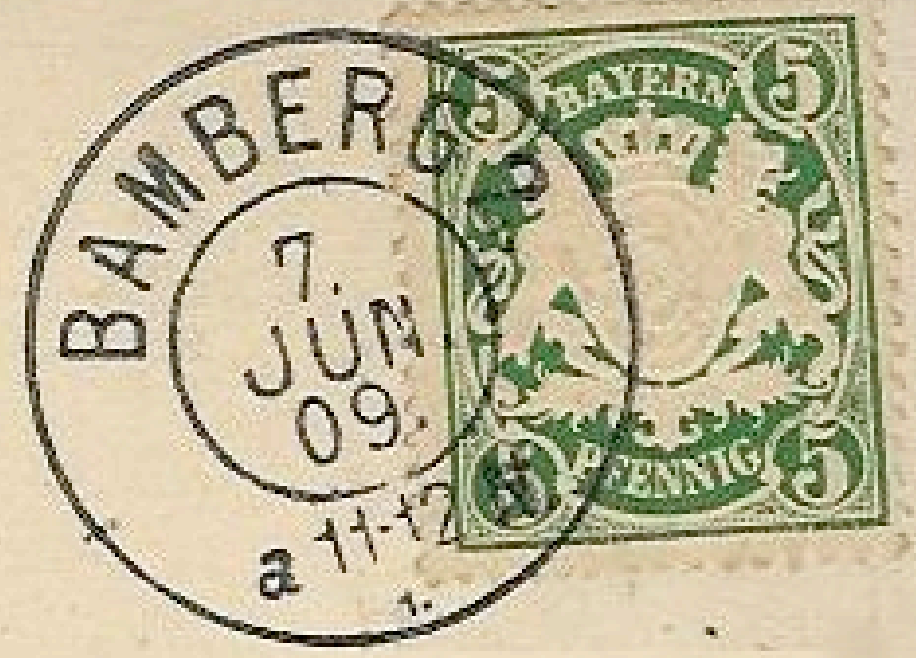

Bulg. + Dt., Franz. Serb./Kroat. + Dt. 


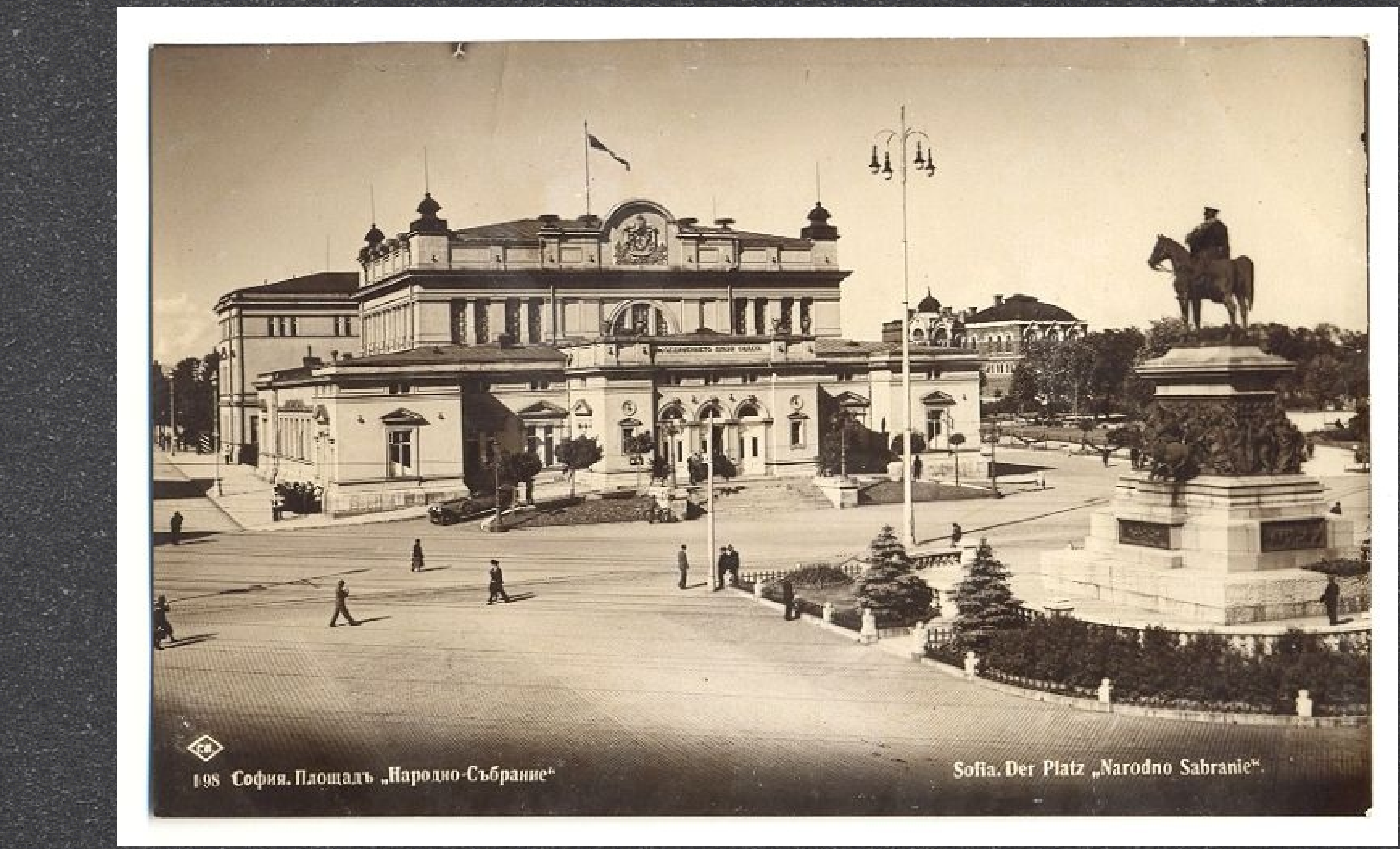

\section{София. Площадъ "Народно Събрание" Sofia. Der Platz "Narodno Sabranie".}




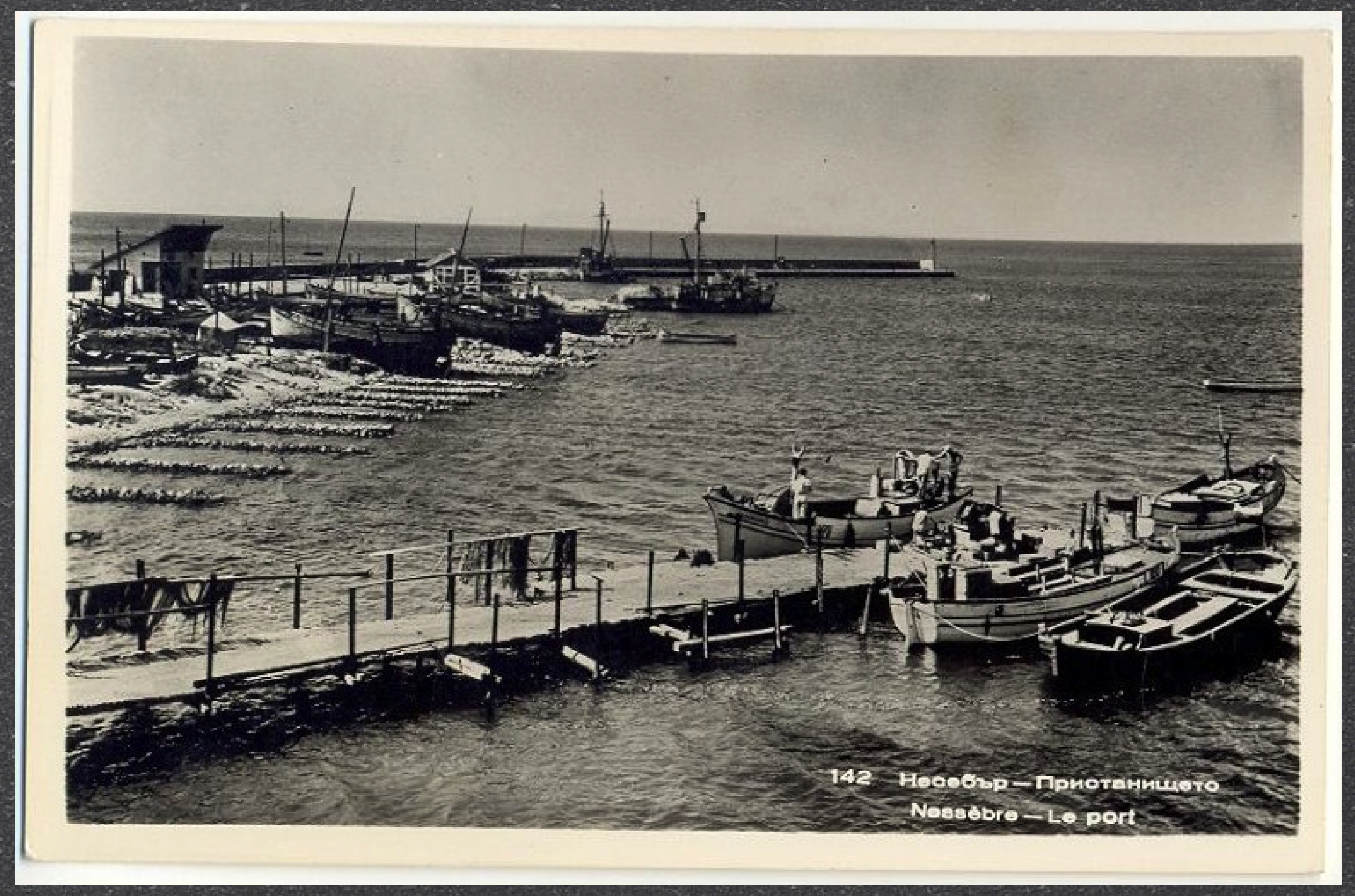

Несебър - Пристанището

Nessebre - Le port 


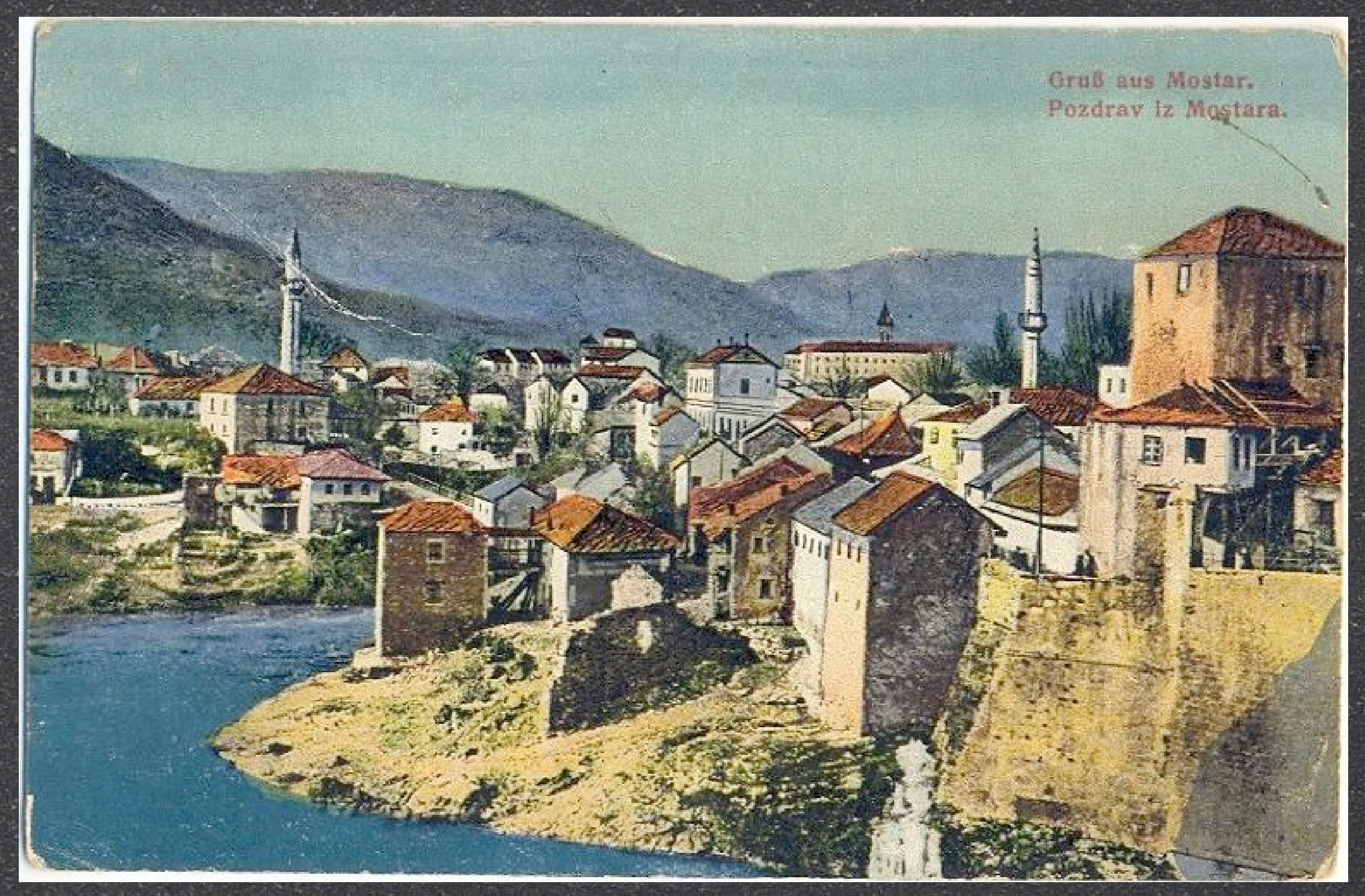

\section{Gruß aus Mostar. Pozdrav iz Mostara}




\section{Postkarte.}

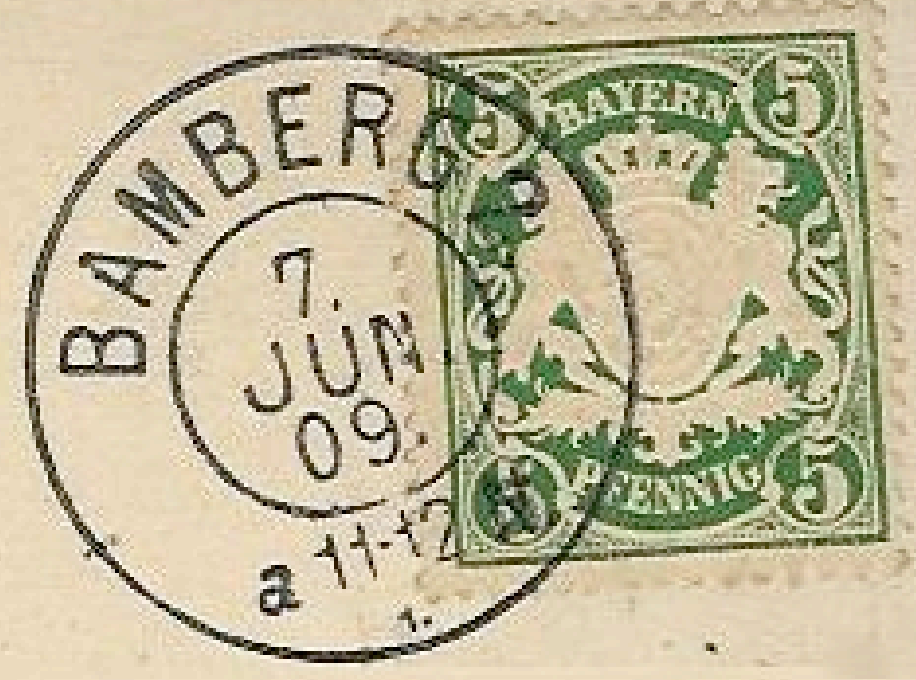

\section{Ganz selten:}

Englisch 

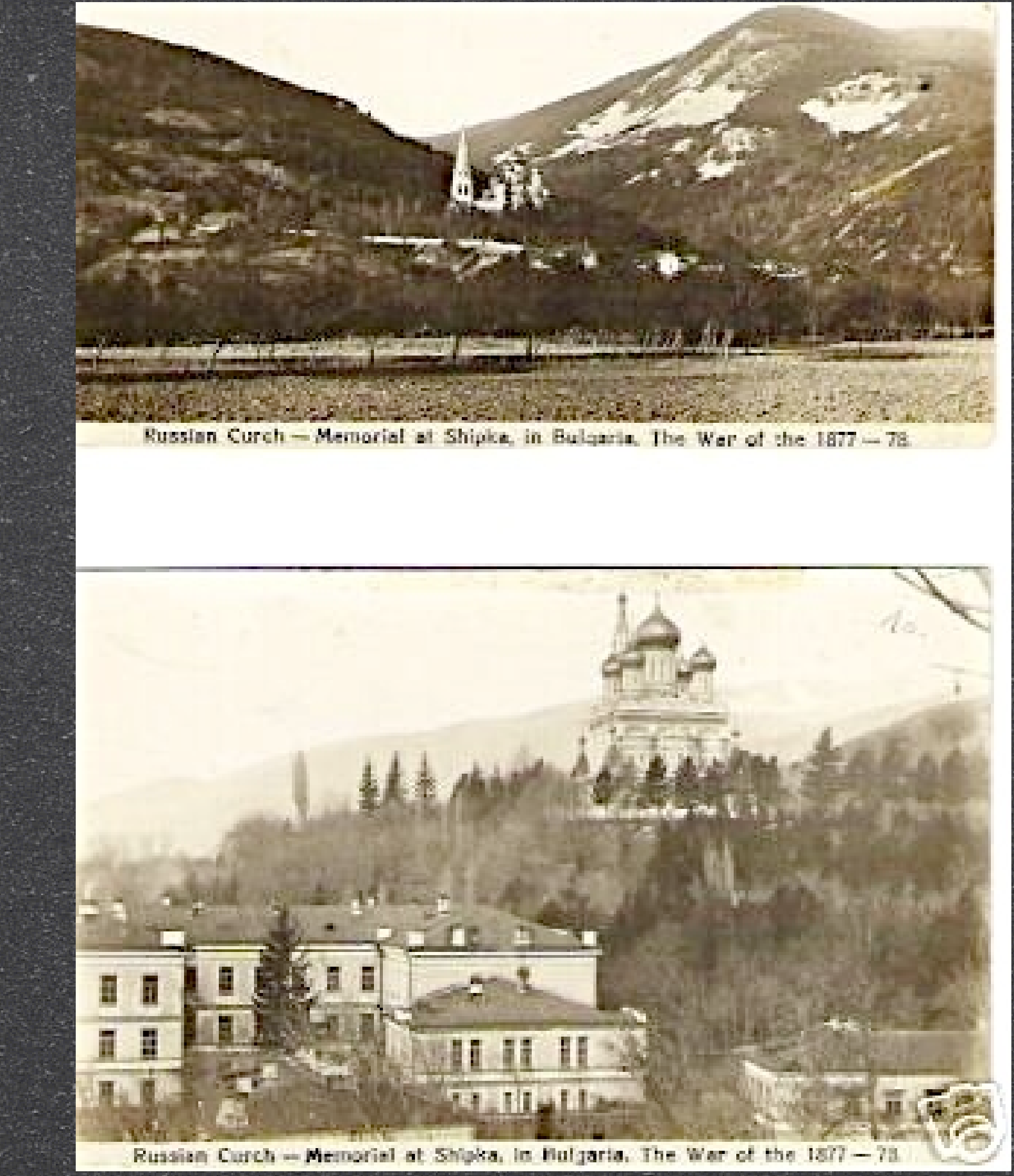

"Russian

Church -

Memorial at Shipka, in

Bulgaria.

The War of

the

1877-78." 


\section{Postkarte.}

Zahl der Sprachen

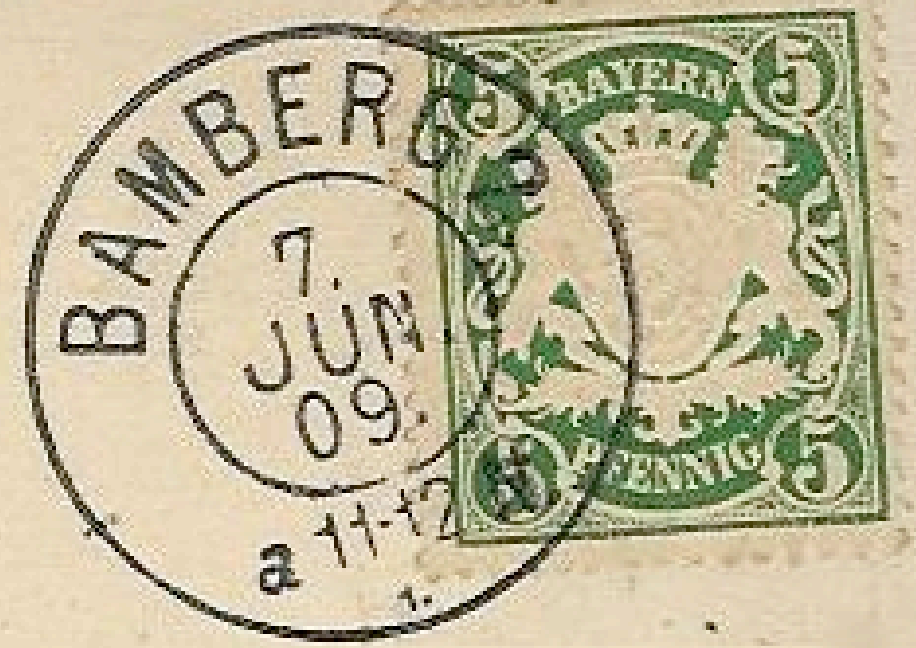

Bulgarien: 0, 1-2

Serb./Kroat.: 0, 1-3 


\section{Sprachen (selten)}

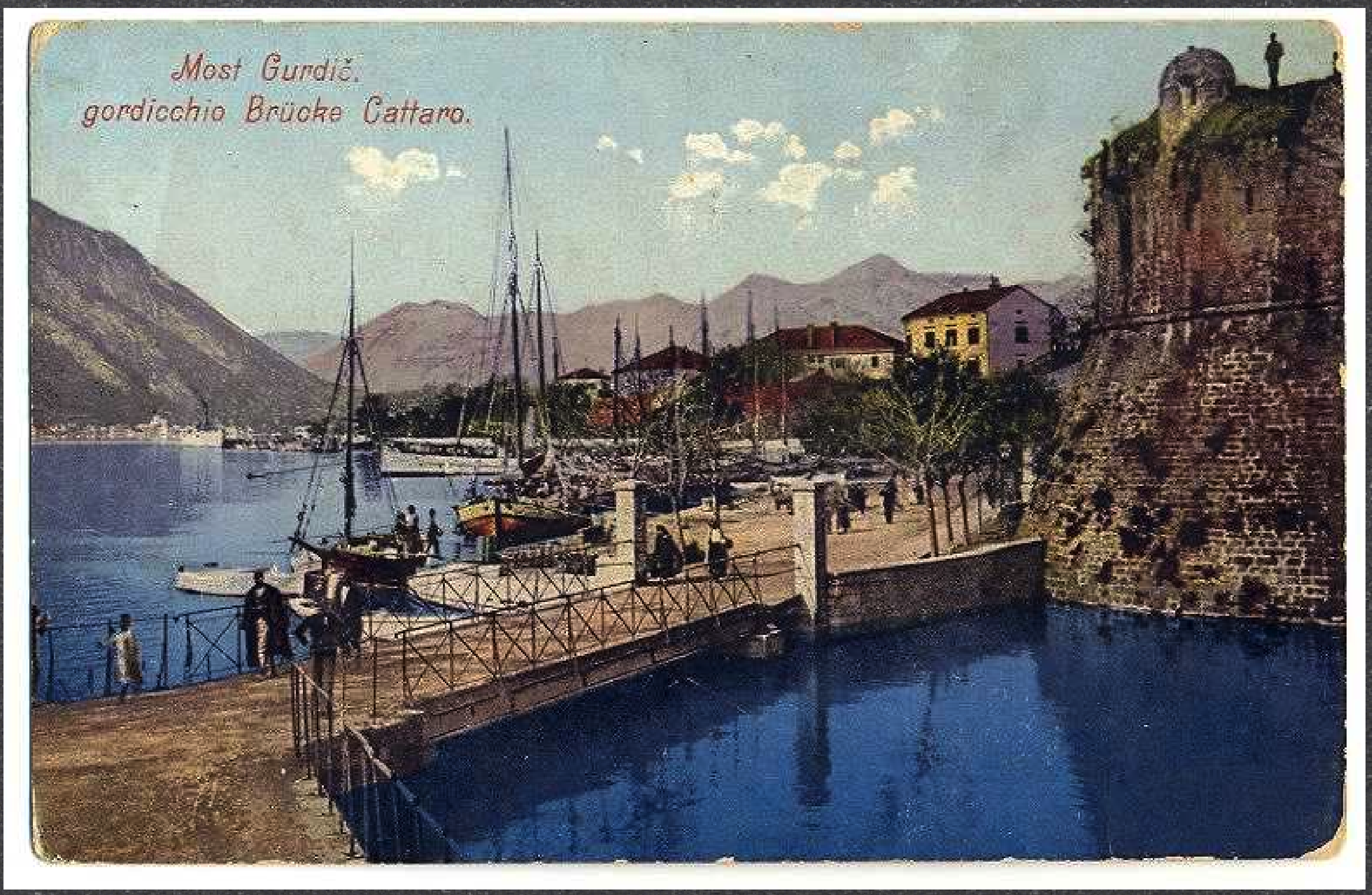

Most Gurdič.

gordicchio Brücke Cattaro 


\section{Sprachen (selten).}

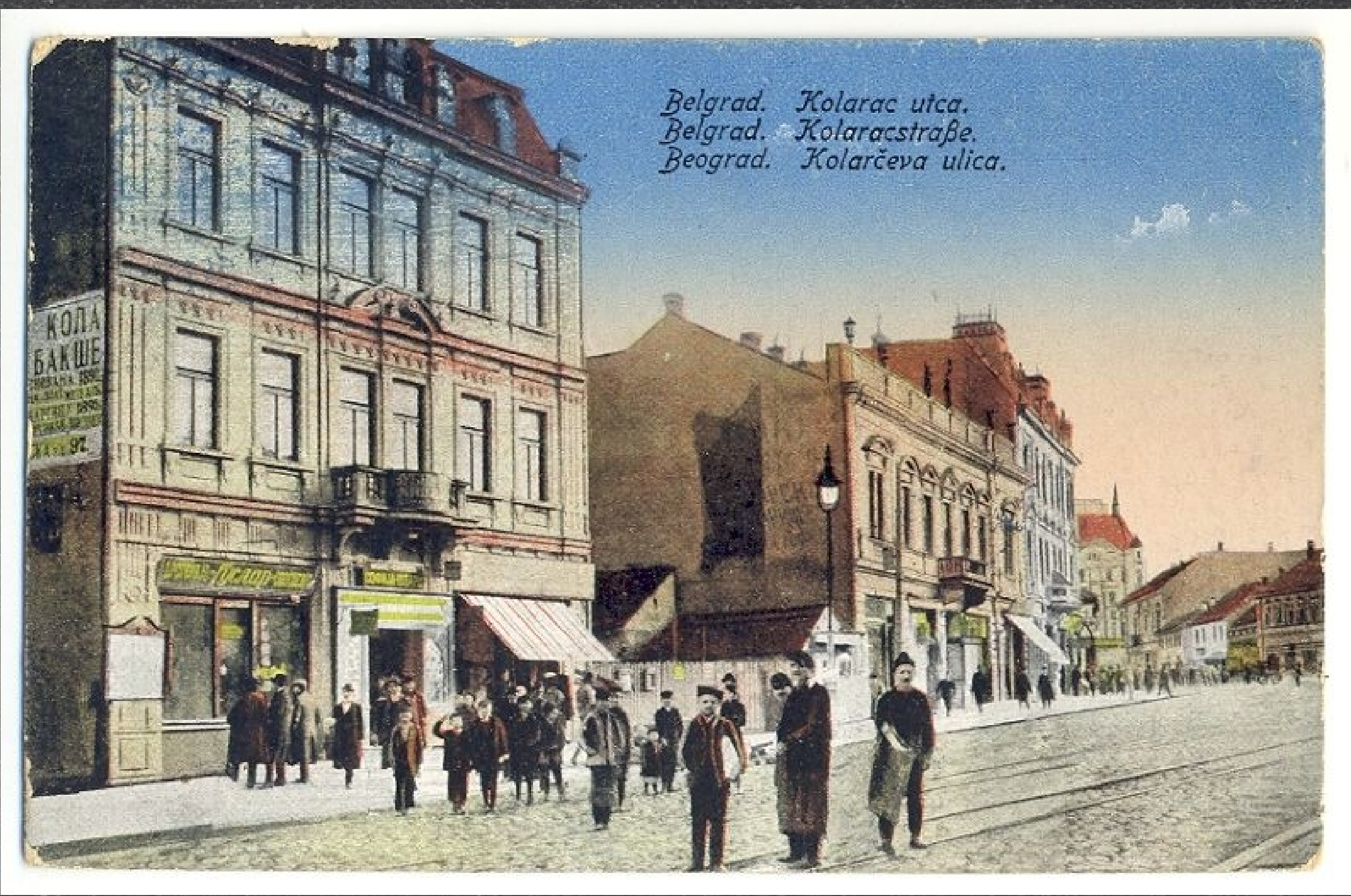

Belgrad. Kolarac utca, Kolaracstraße. Beograd. Kolarčeva ulica 


\section{Schriften}

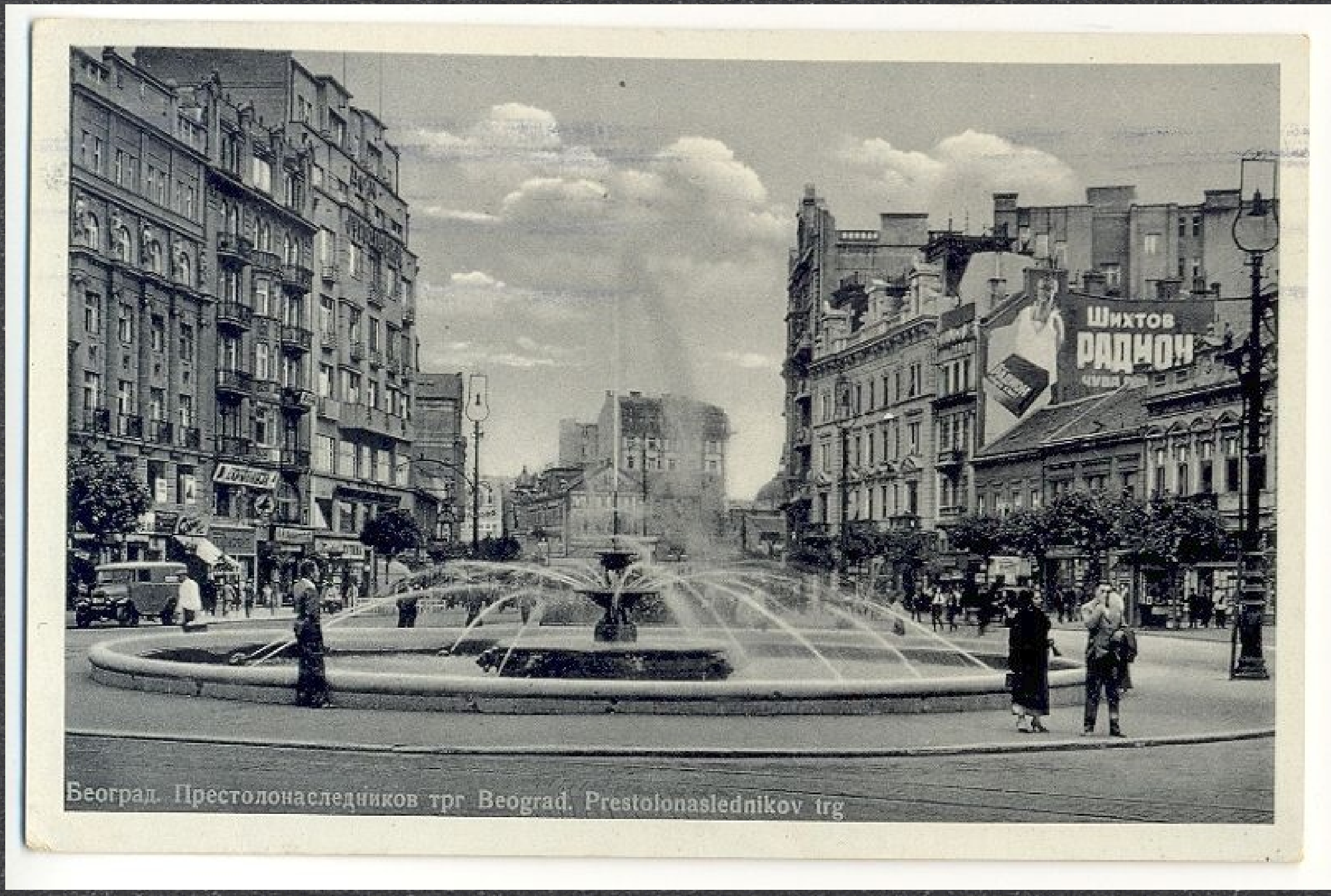

Београд. Престолонаследников трг. Beograd. Prestolonaslednikov trg 


\section{Schriften}

Сарајево

Sarajevo

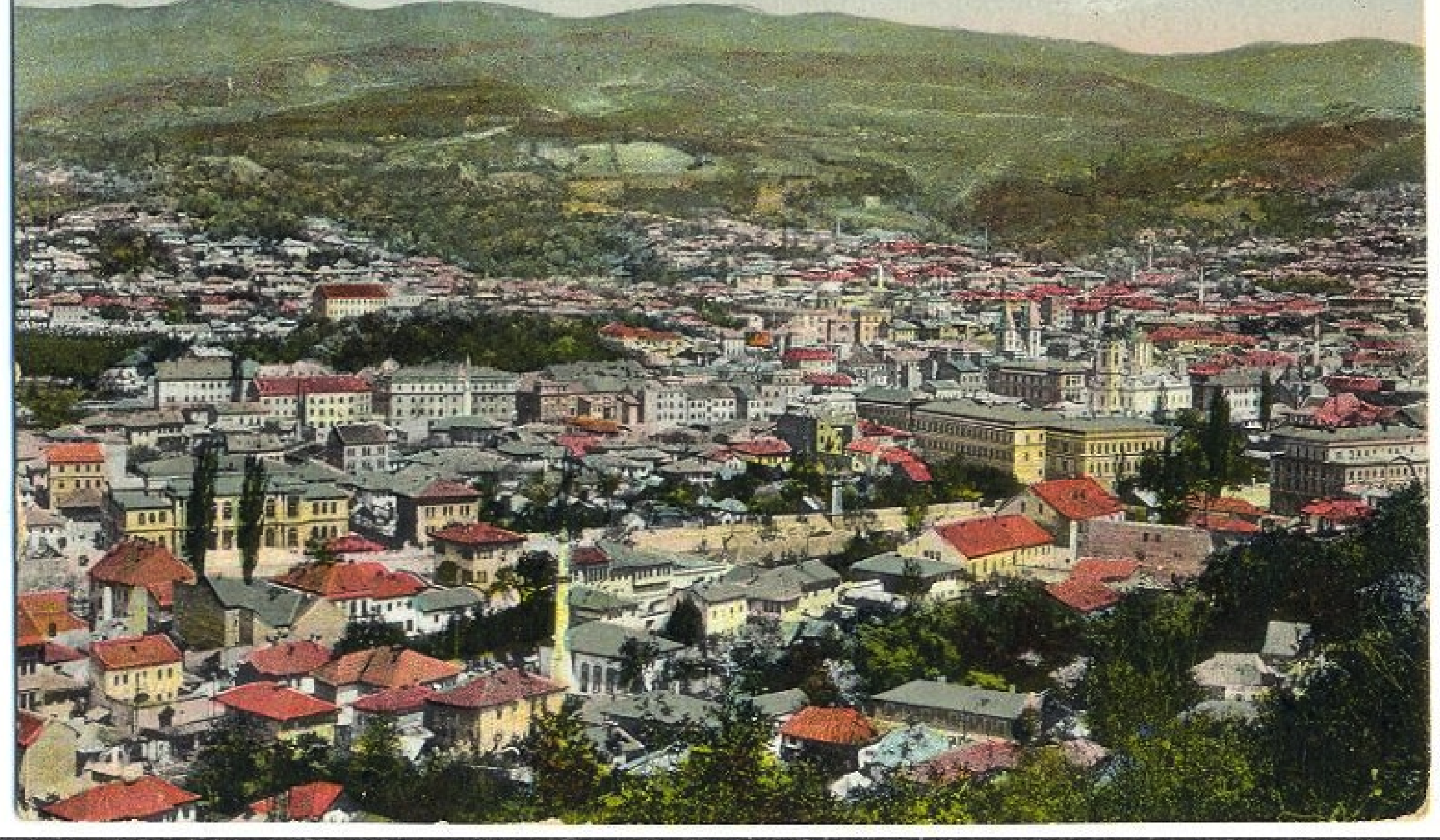

$$
\text { Capajeвo - Sarajevo }
$$


2 Sprachen, 2 Schriften

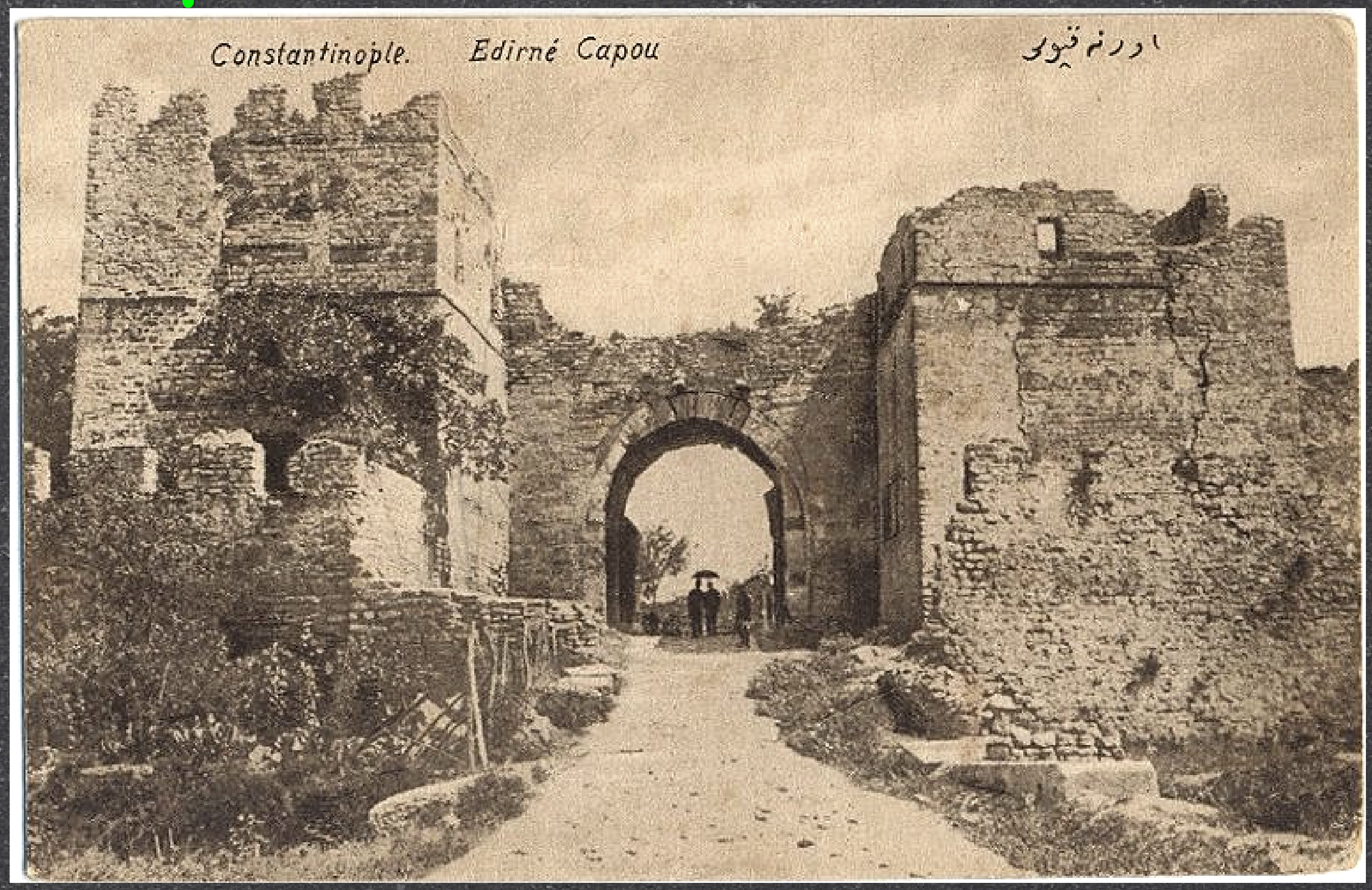

Edirné Capou • Edirne kapısı (Türk.

arab. Schrift: ,Das Edirne-Tor') 


\section{Postkarte.}

Nachbarsprachen,

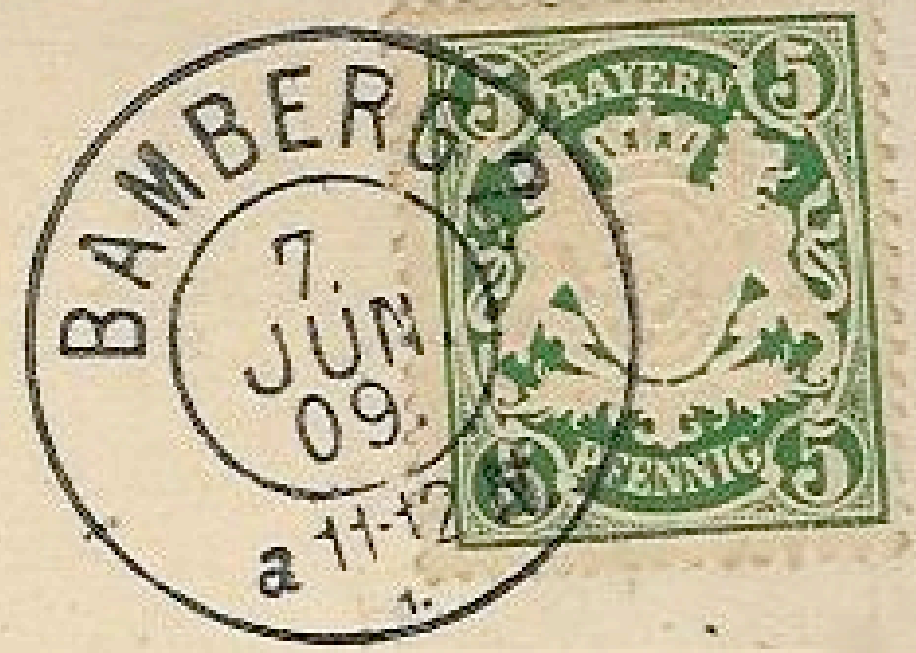

Kontaktspr., Minderheiten

- einzelne Fälle 


\section{Ruse (Bg.): rumänisch}

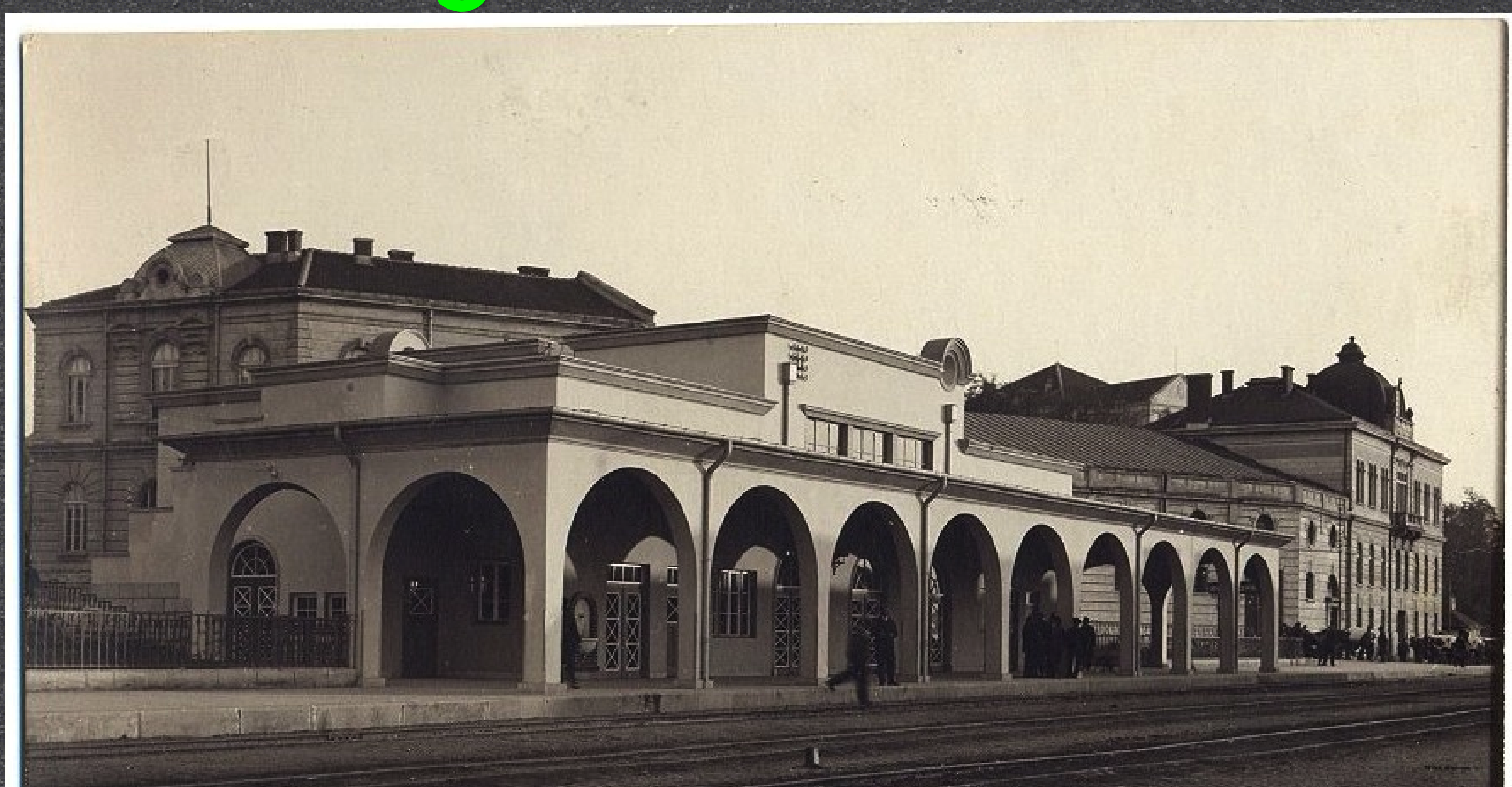

(n)

70 Русе. Гарата на пристанището

Russe, Der Bahnhof am Hafen

Ruse Cefstacidomo apud Danubo 


\section{Belgrad: ungarisch}

Belgrad. Frerceg Mihály utca.
Belgrad. Furst Michaelstraße.
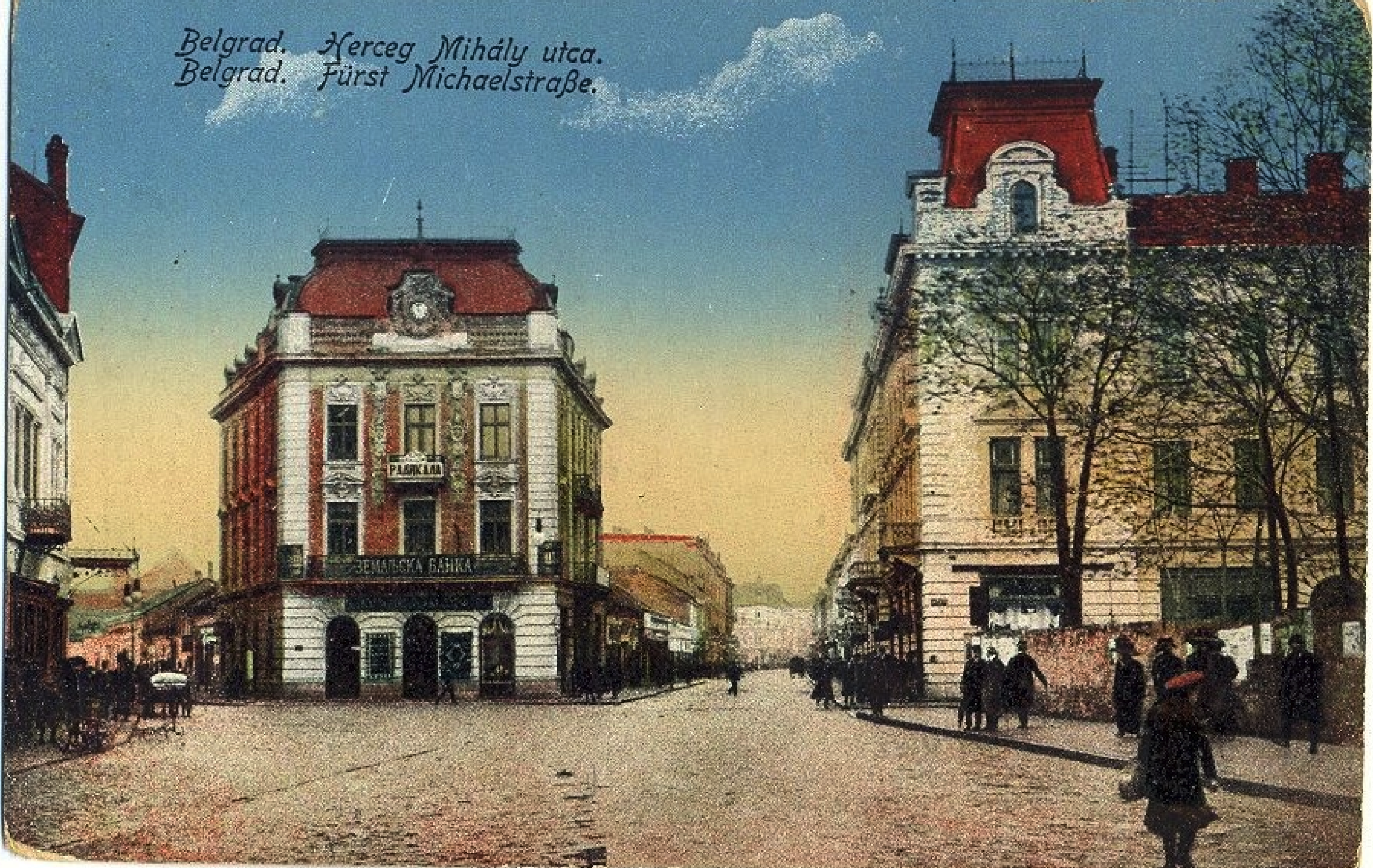
(4.
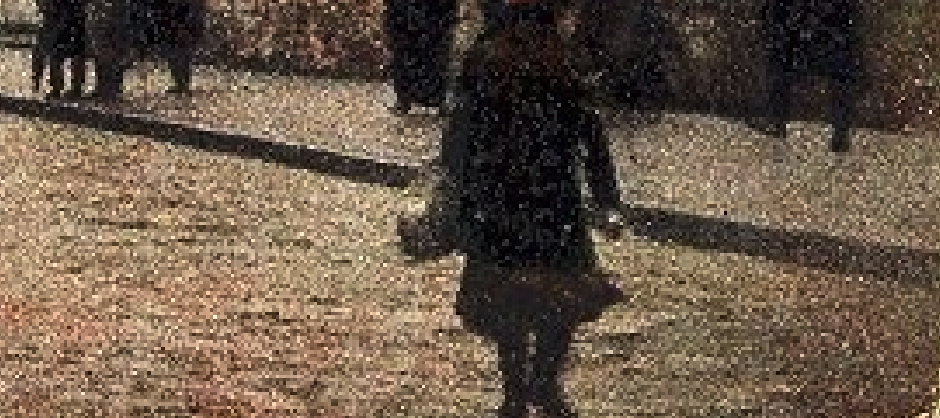


\section{Šibenik: italienisch}

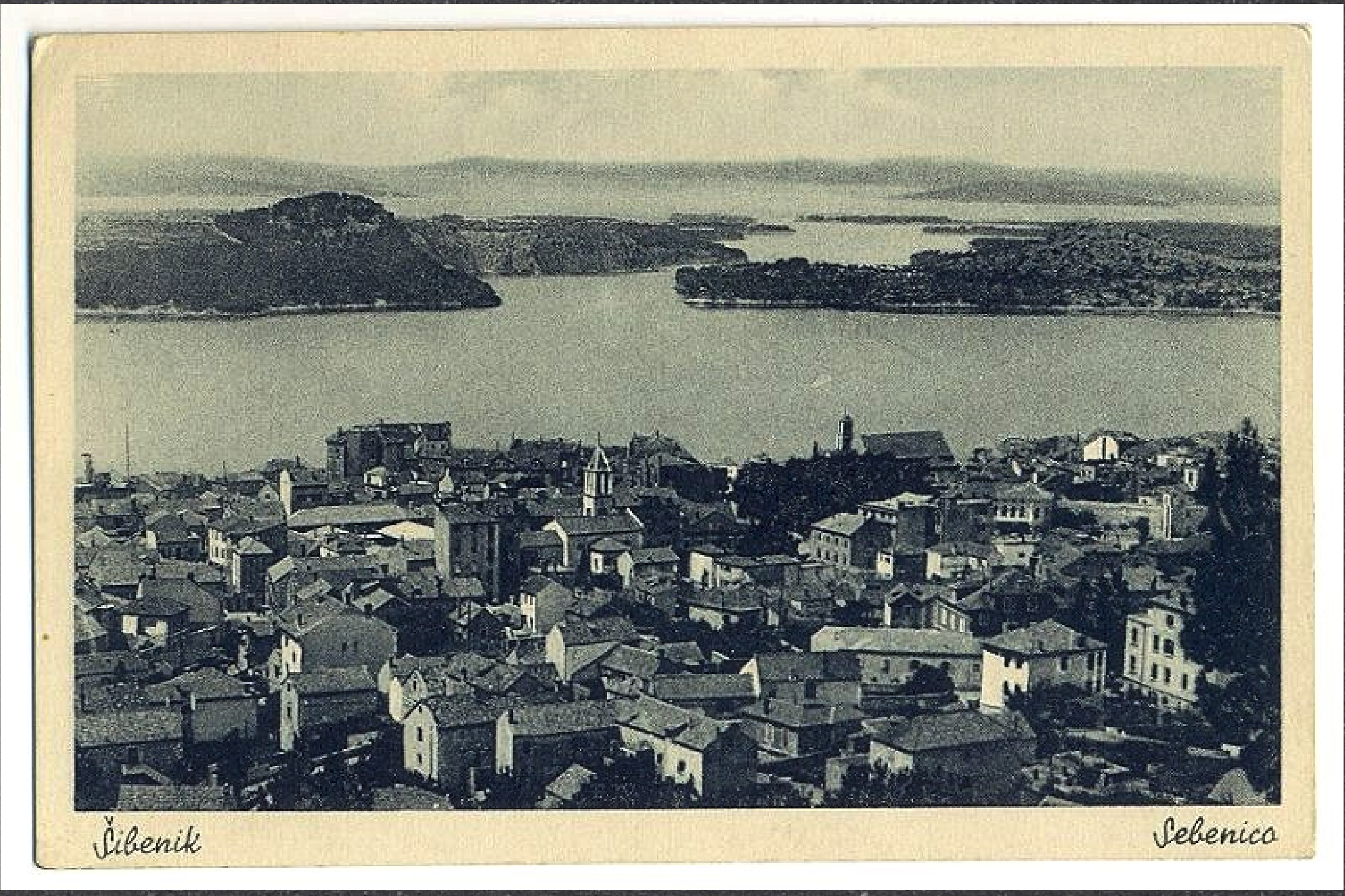




\section{Kotor: italienisch}

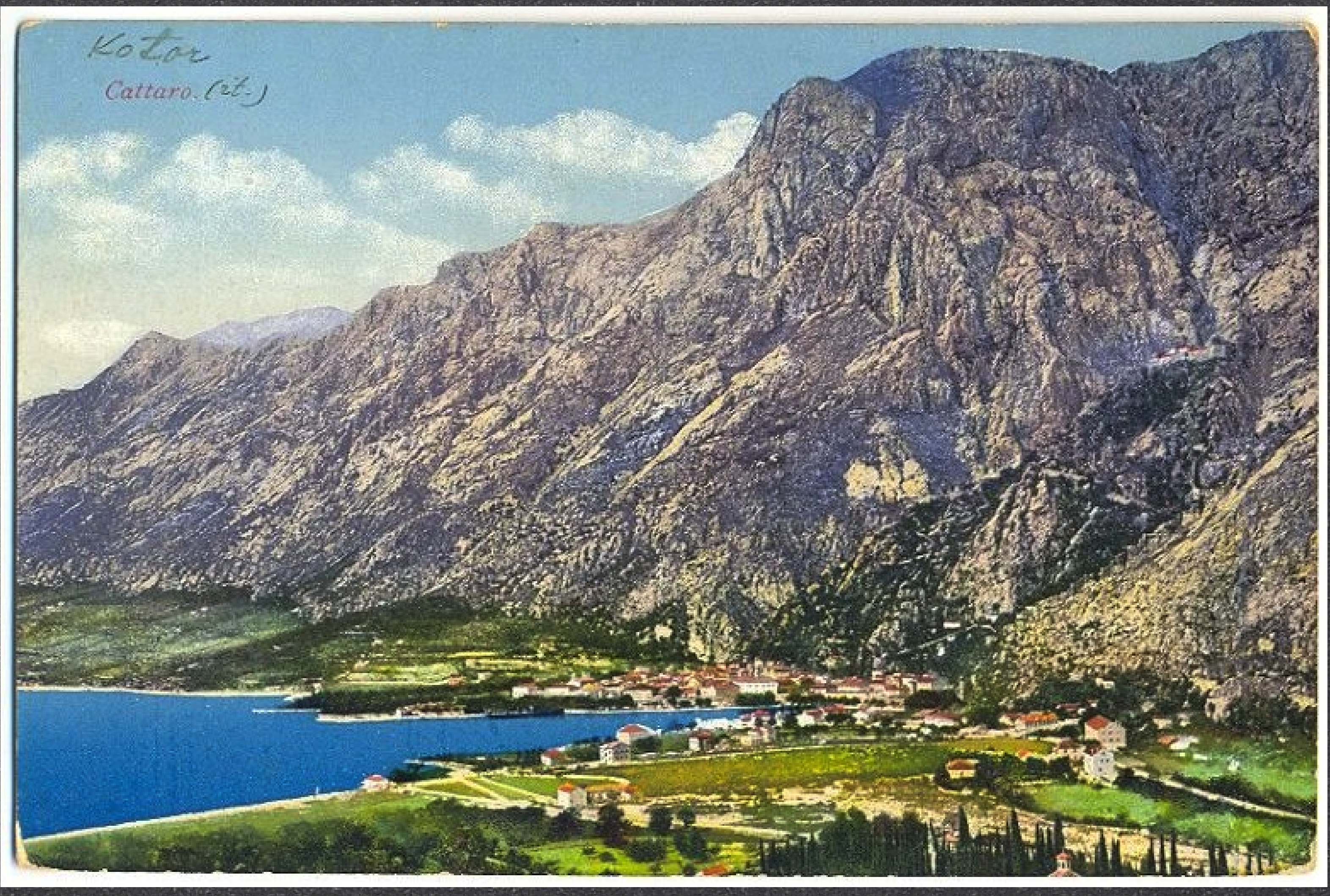




$$
\text { Postkarte. }
$$

In Bulg. nicht belegt: Griechisch, Türkisch, Albanisch, Russisch 


\section{Postkarte.}

Relativ selten:

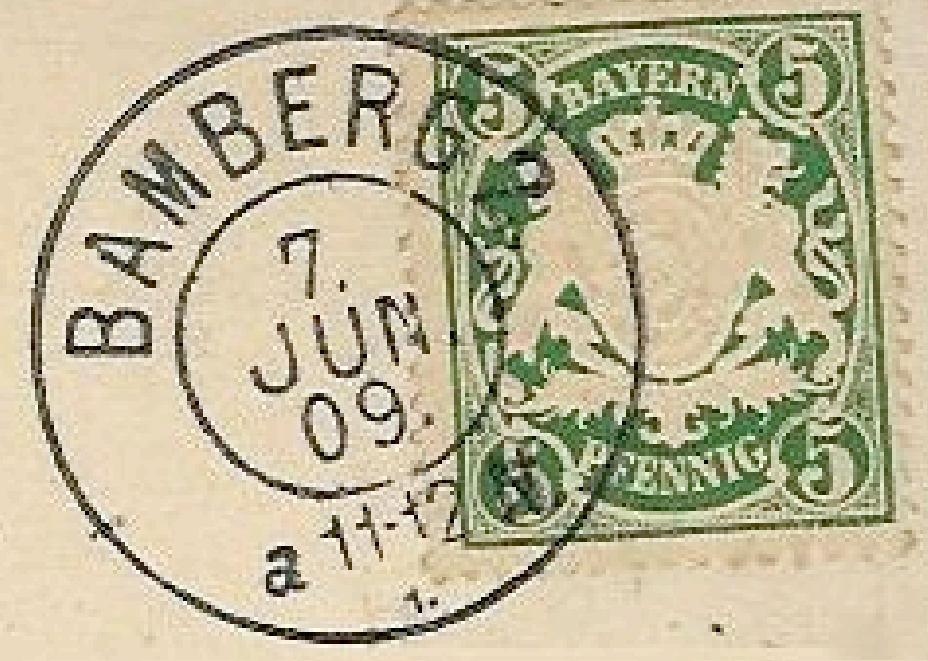

Türkisch auf Istanbuler

Postkarten 


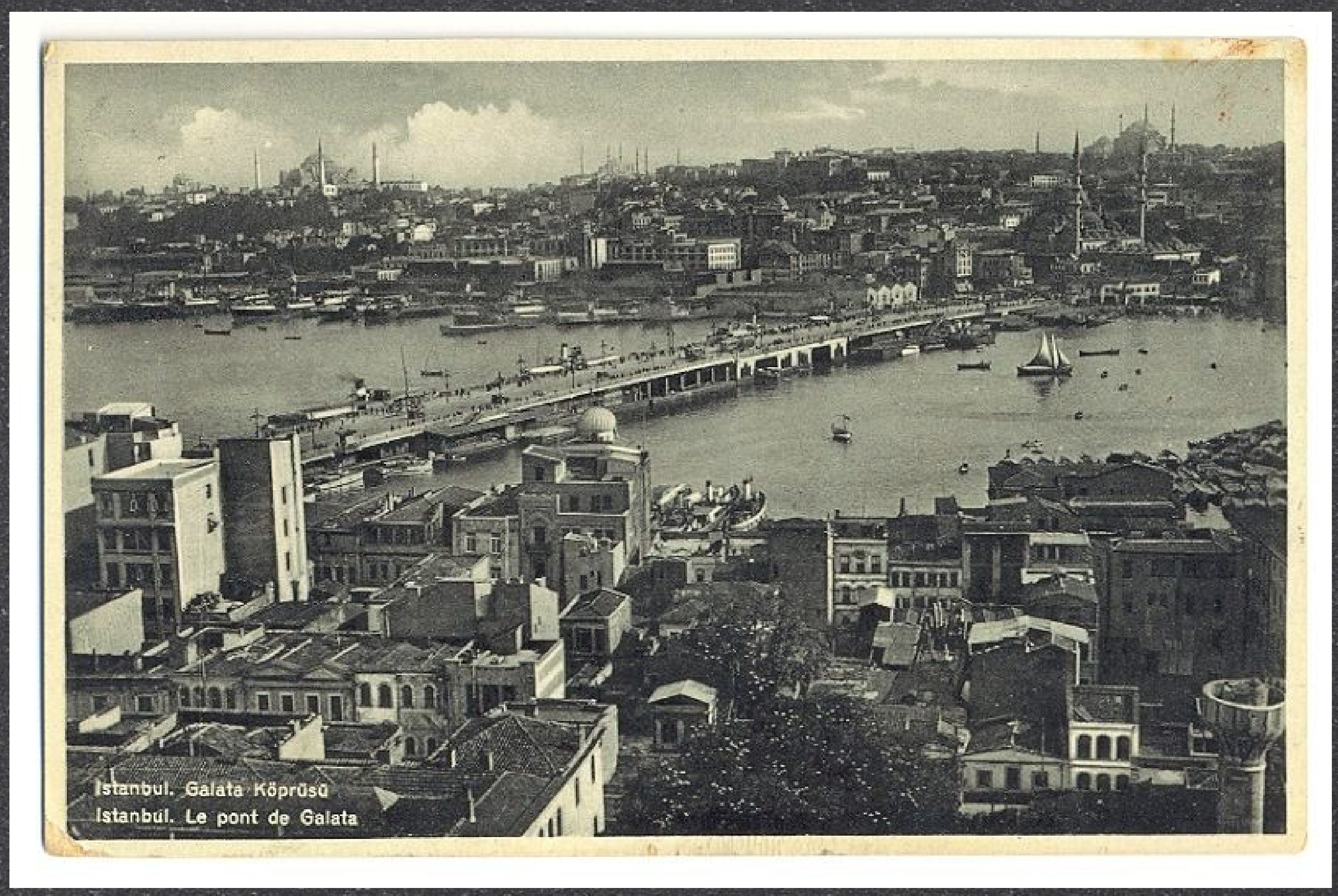

\section{Istanbul. Galata Köprüisü. Istanbul. Le pont de Galata}




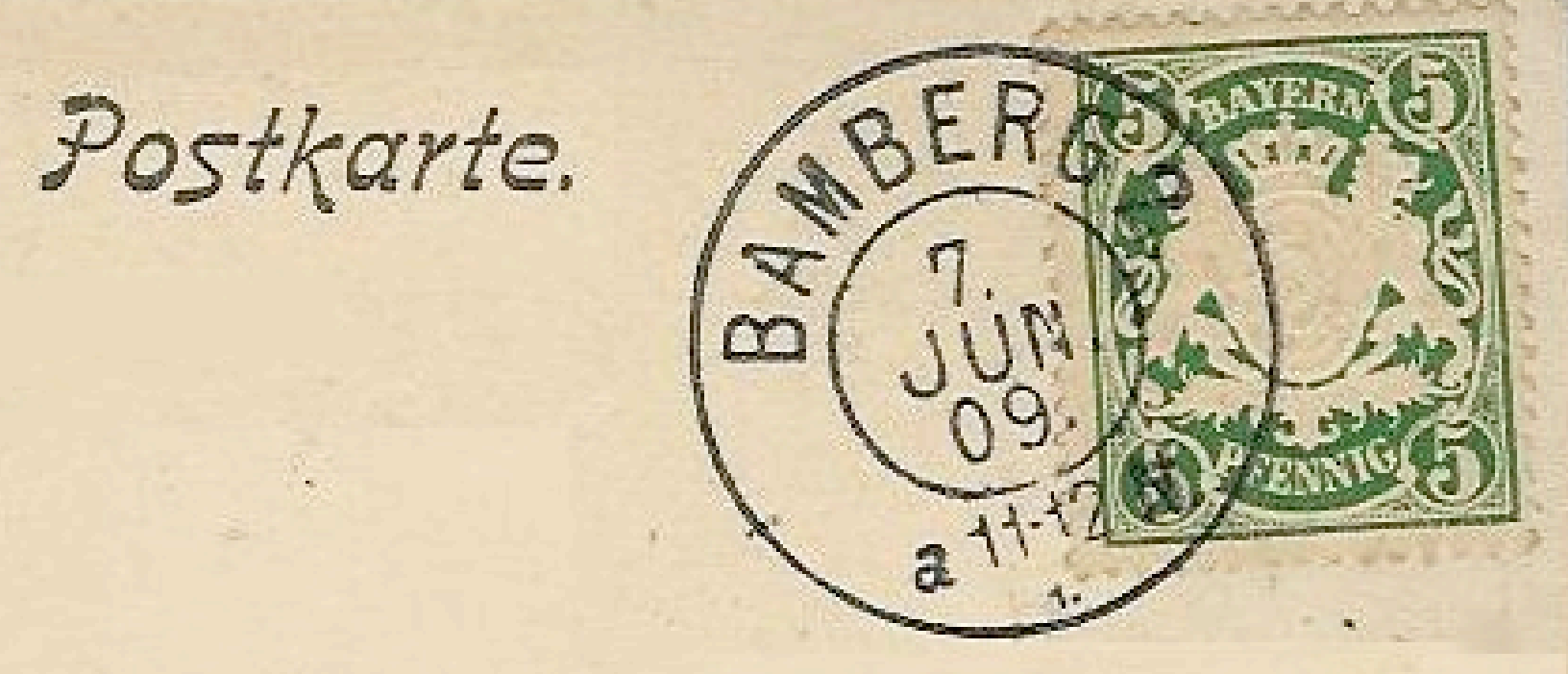

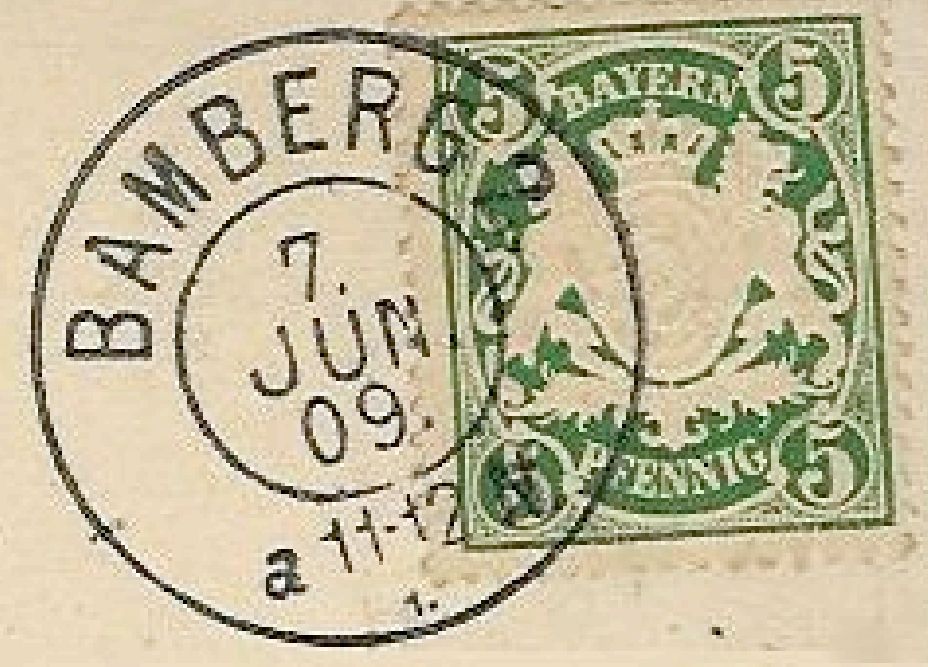

Immer nur einsprachig: Albanien 


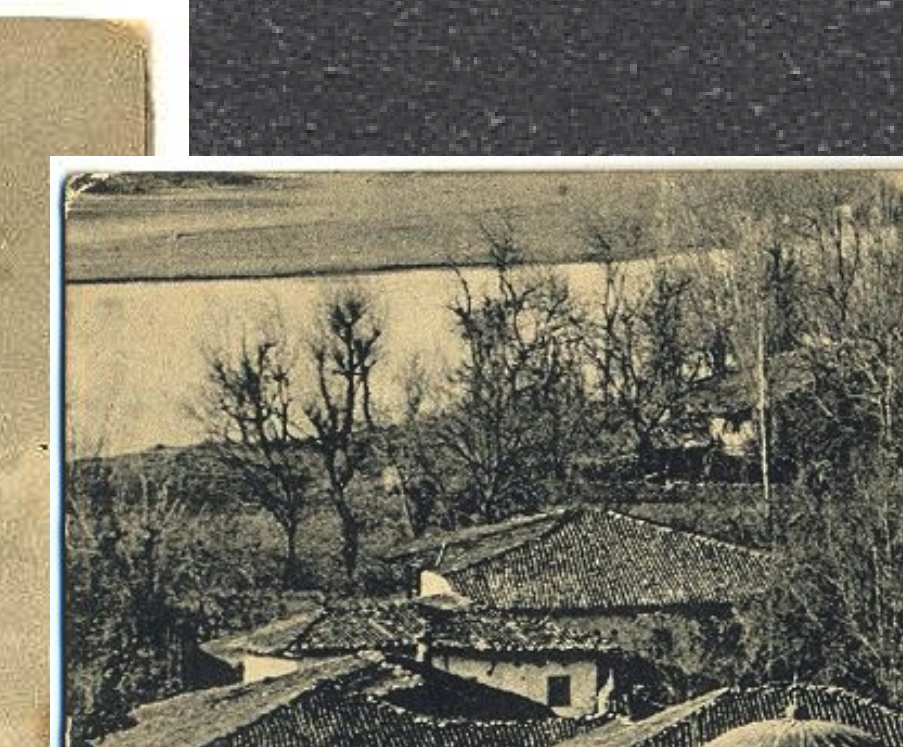

Xhamija é Plumit - Skutari (Shqypènie).

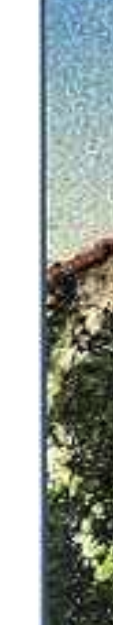

\section{的}

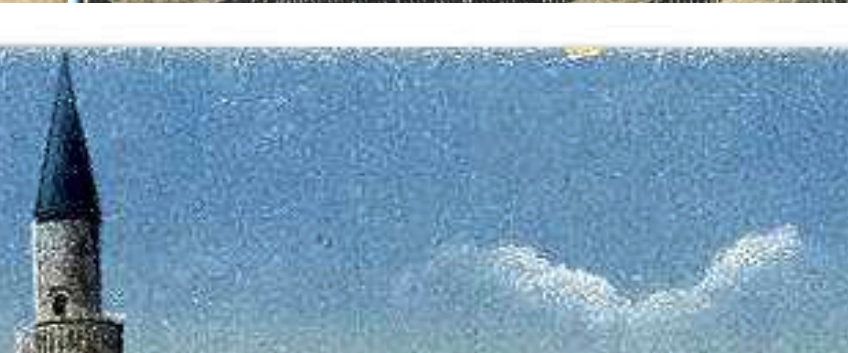

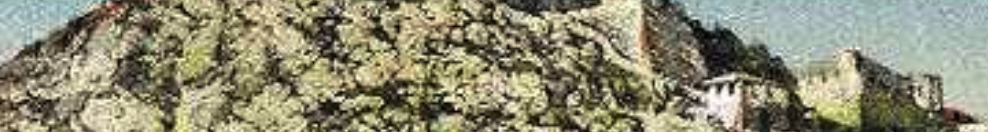

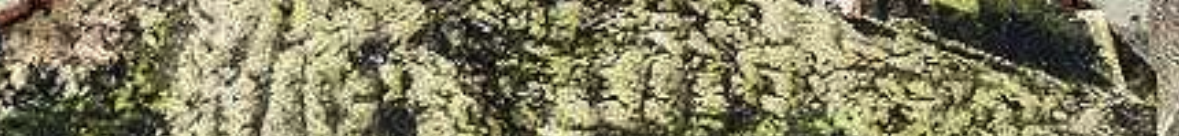

n.

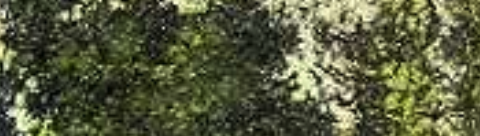

1. . - 1

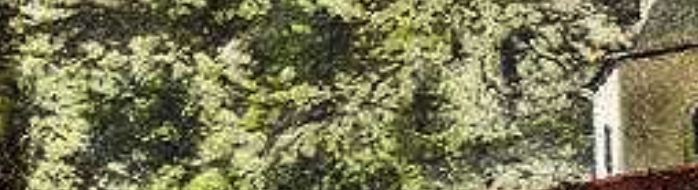

(x)
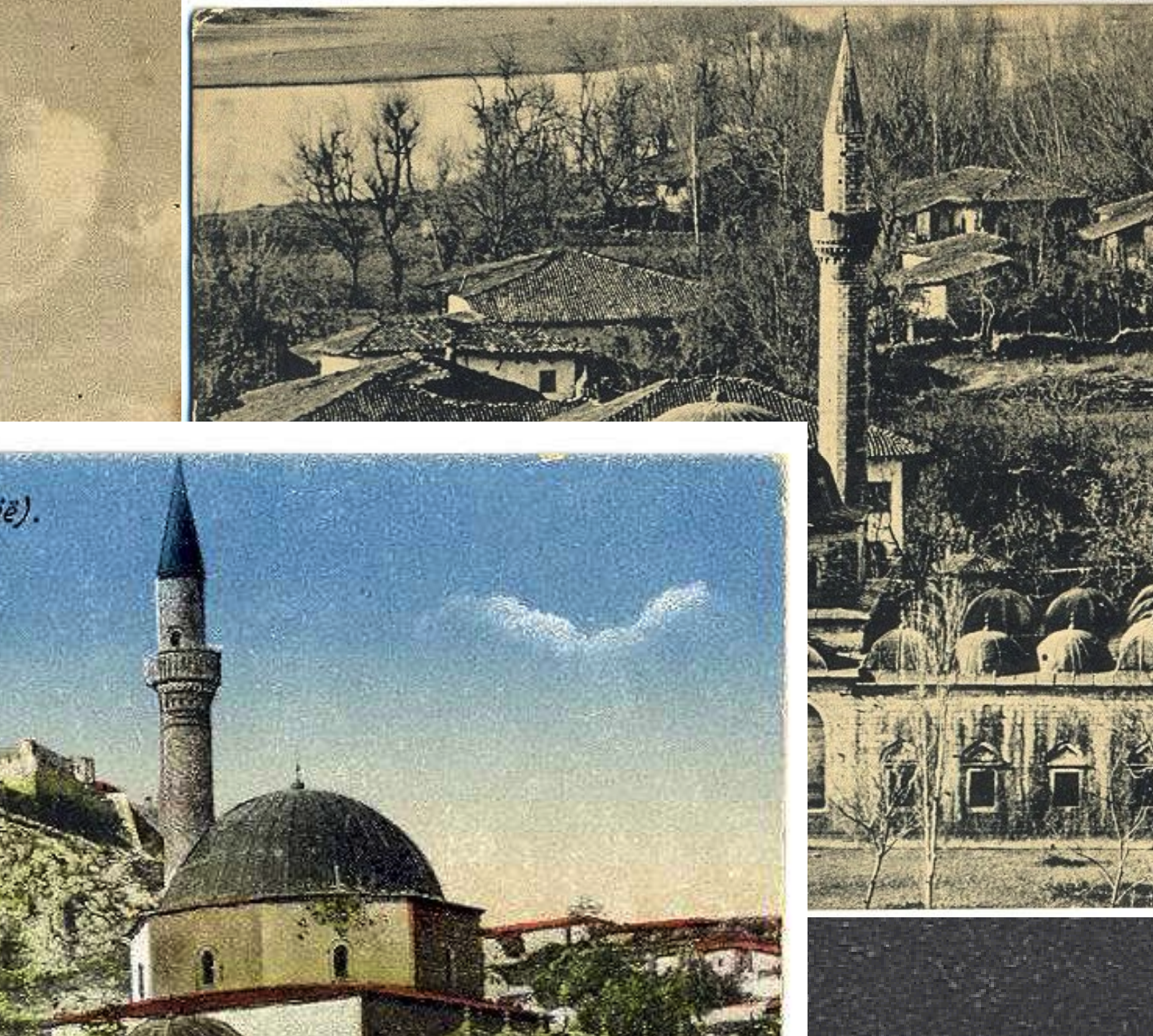

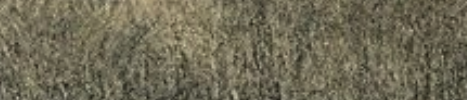

Kujtim

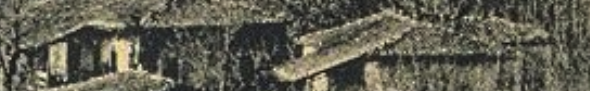

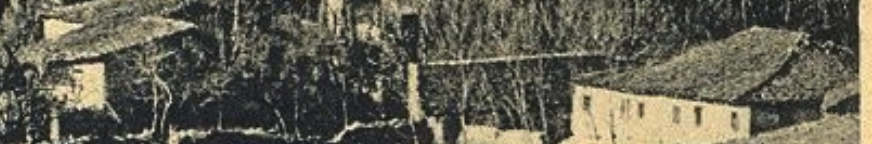

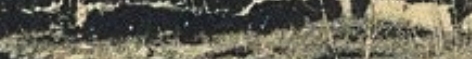
remp
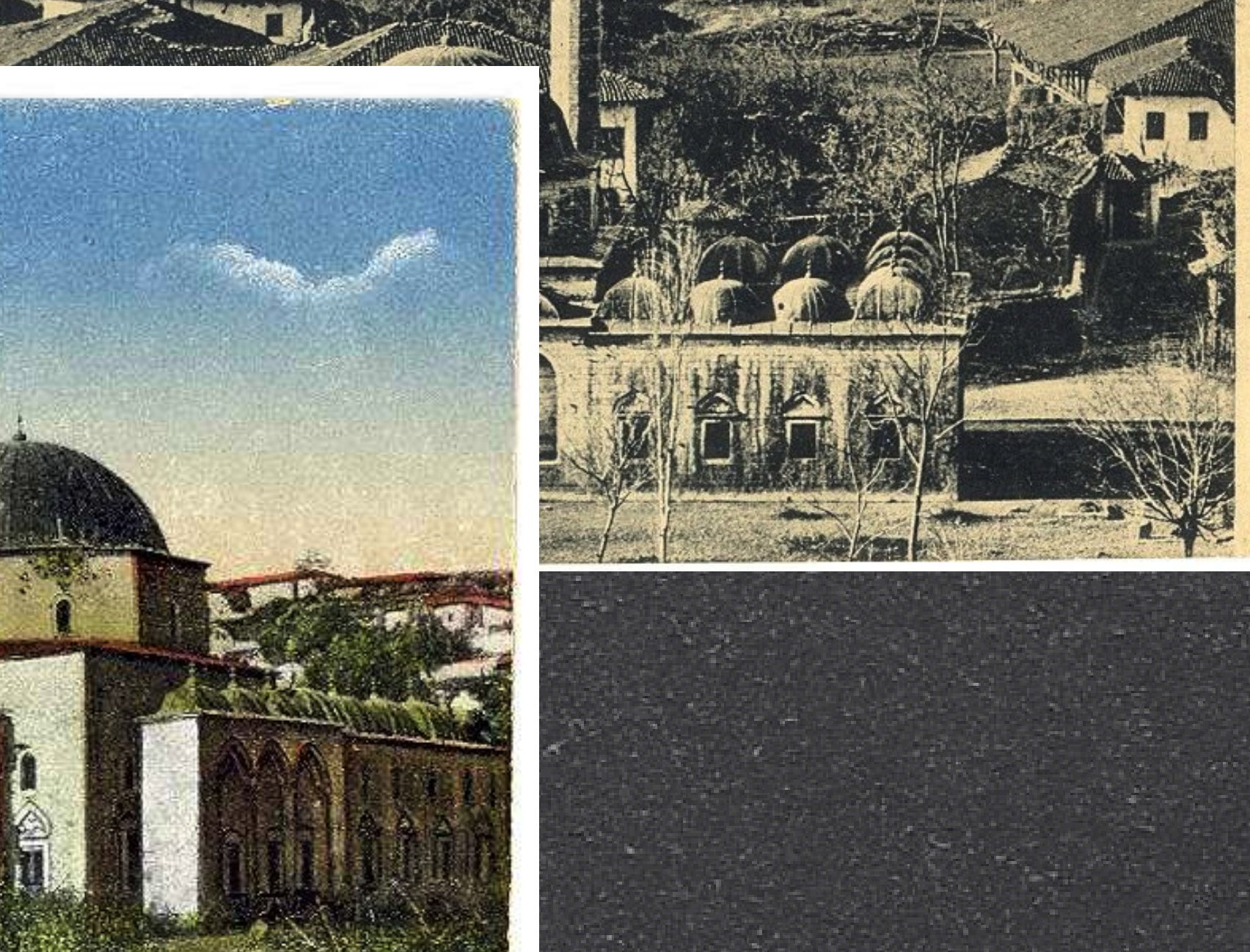

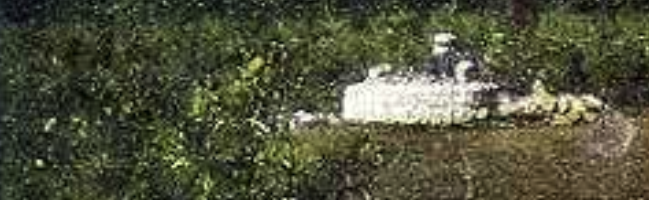

n.'.

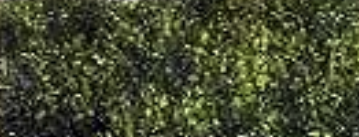
3.

Kujtim nga Sqypënia - Xhamia Ehtem Beut Tiranẻ • Kujtim nga Shkodra 


$$
\text { Postatere (5) }
$$

Historische Orthographie des Bulgarischen 
$\bar{n}>\mathrm{b}, \mathrm{b} \#>\varnothing$

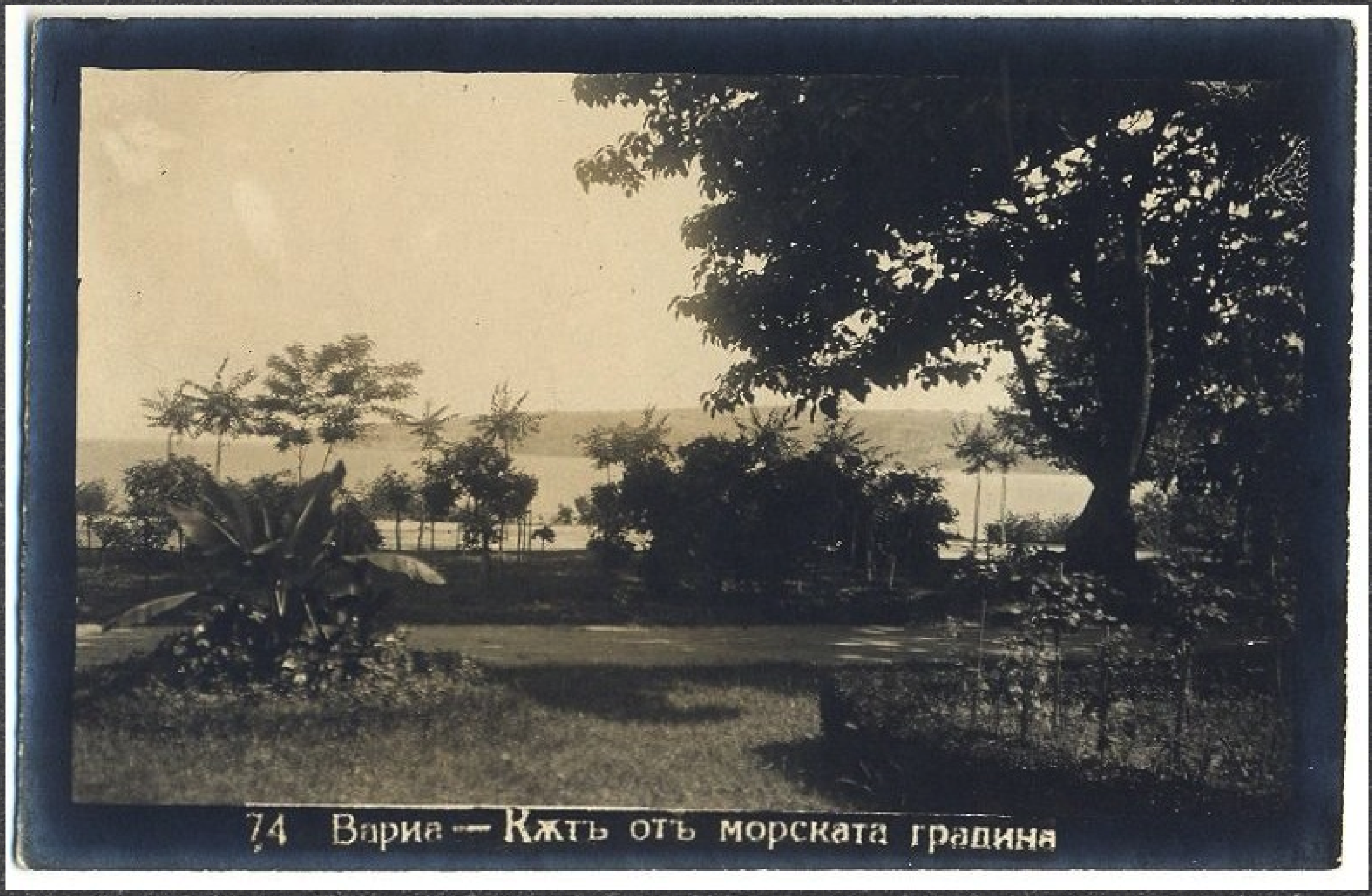

Варна - Кжть от морската градина 
$\mathrm{b}>\mathrm{E} / \mathrm{A}, \mathrm{b} \#>\varnothing$

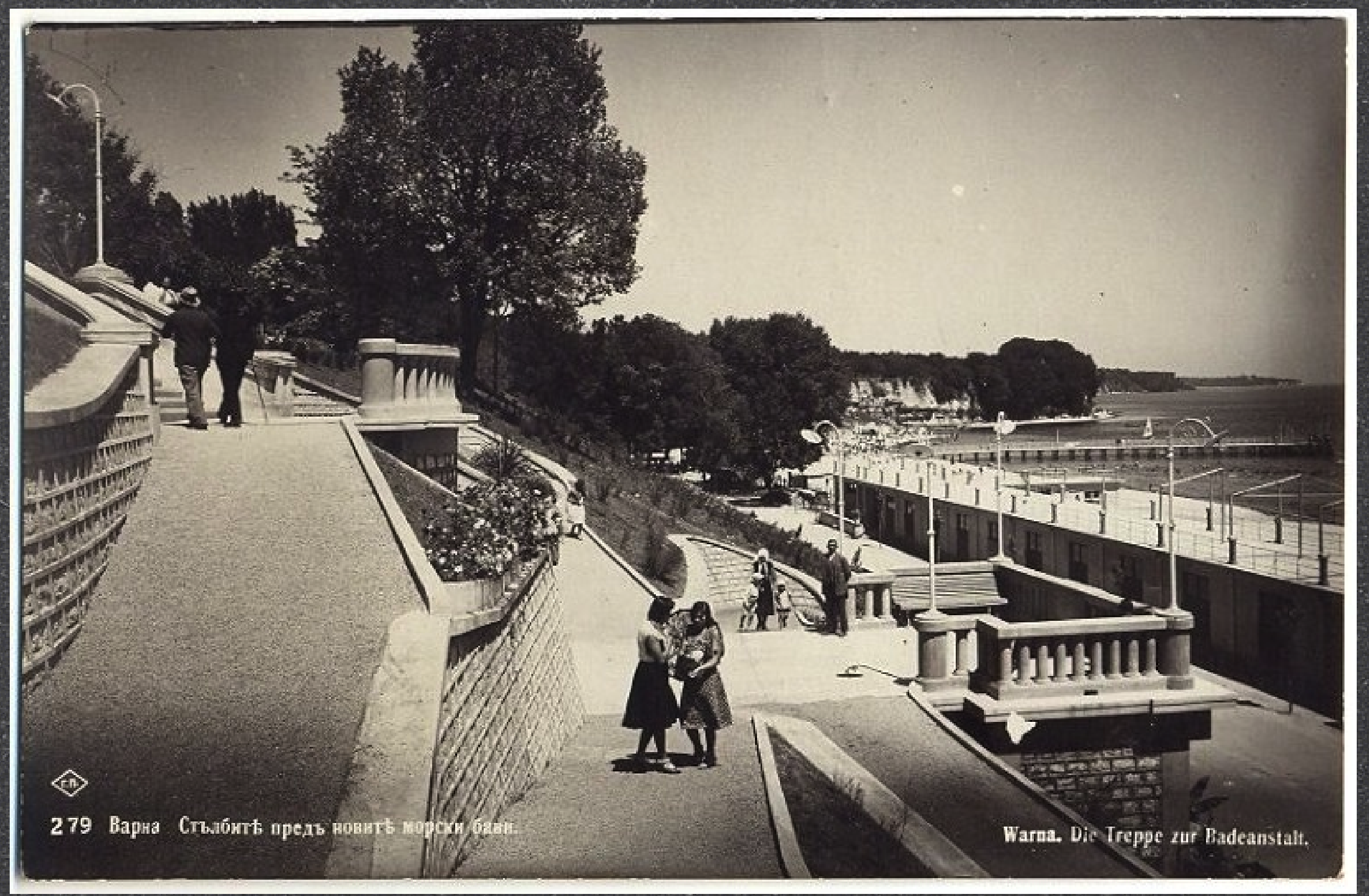

Варна - Стълбить предъ новить морски бани. 


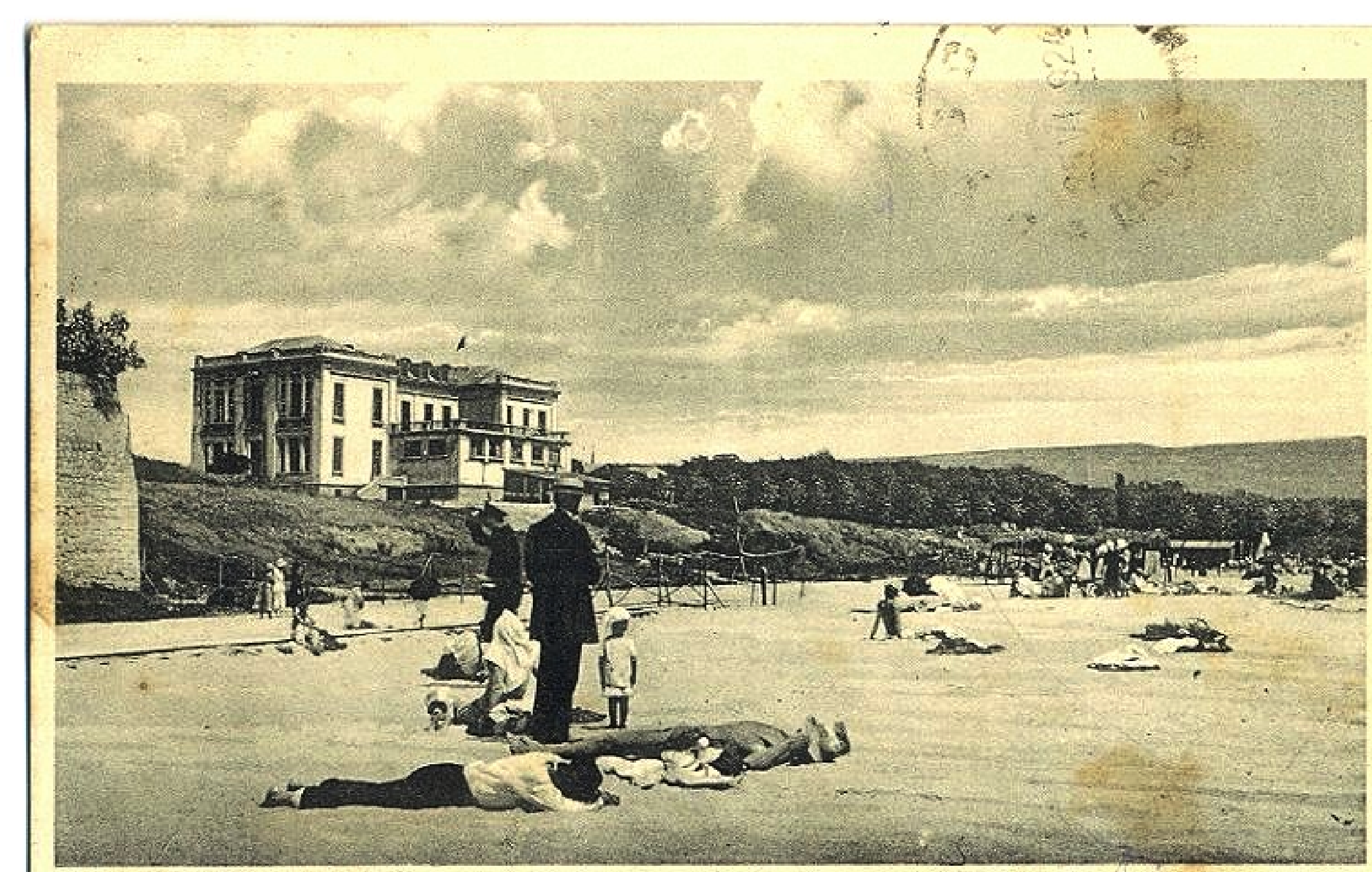

Варна. Морските бани.

Varna. Les bains de mer.

Варна - Морските бани. 


\section{$b>E / a, b \#>\varnothing$}
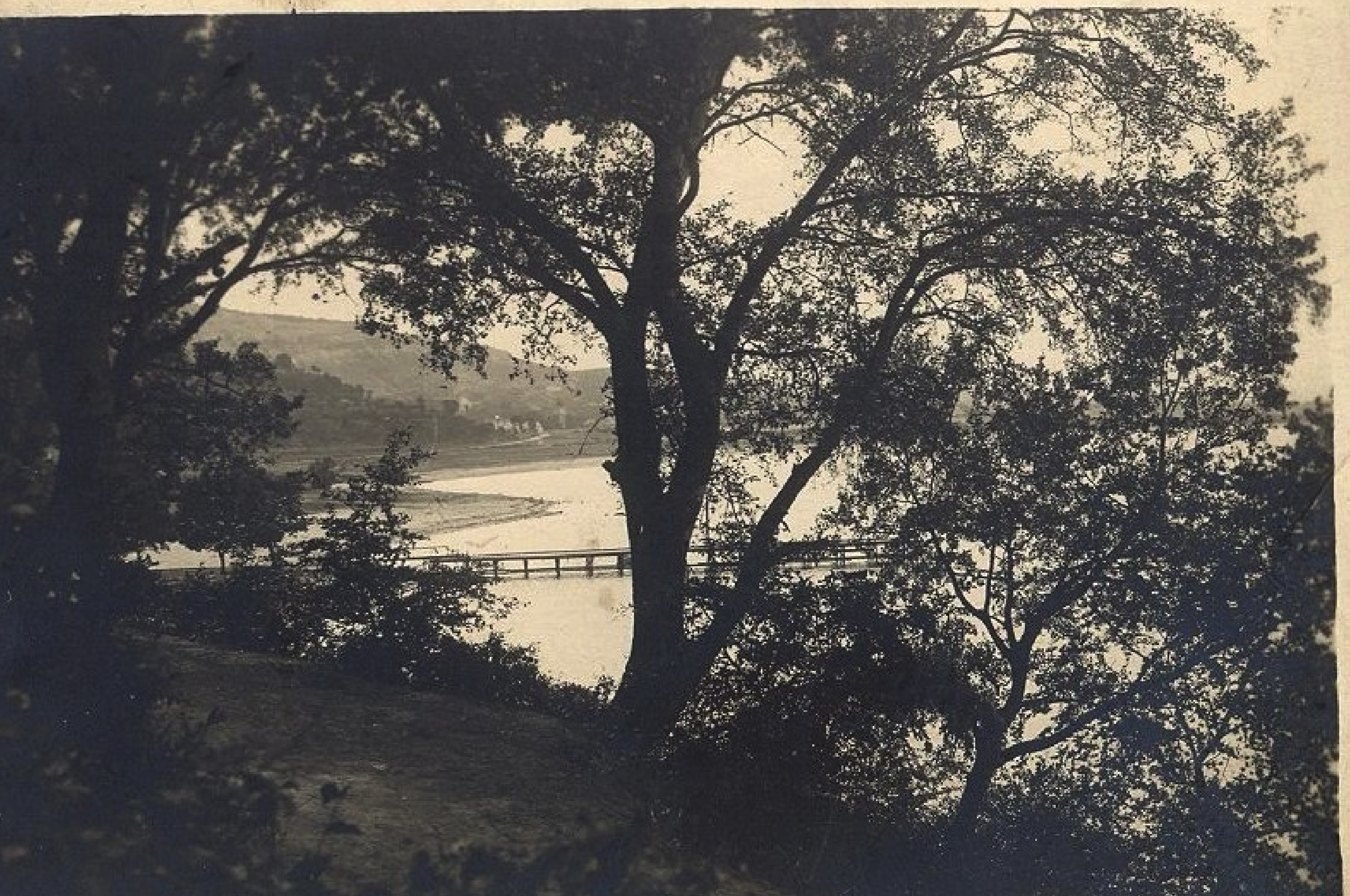

180. Варна. Красивъ Морски брьгъ

Варна - Красивъ Морски брьгь 
$b, b \#>\varnothing$

Шуменъ. Улица „џарь Освободитель:

Schumen. Die Zarbefreierstraße.

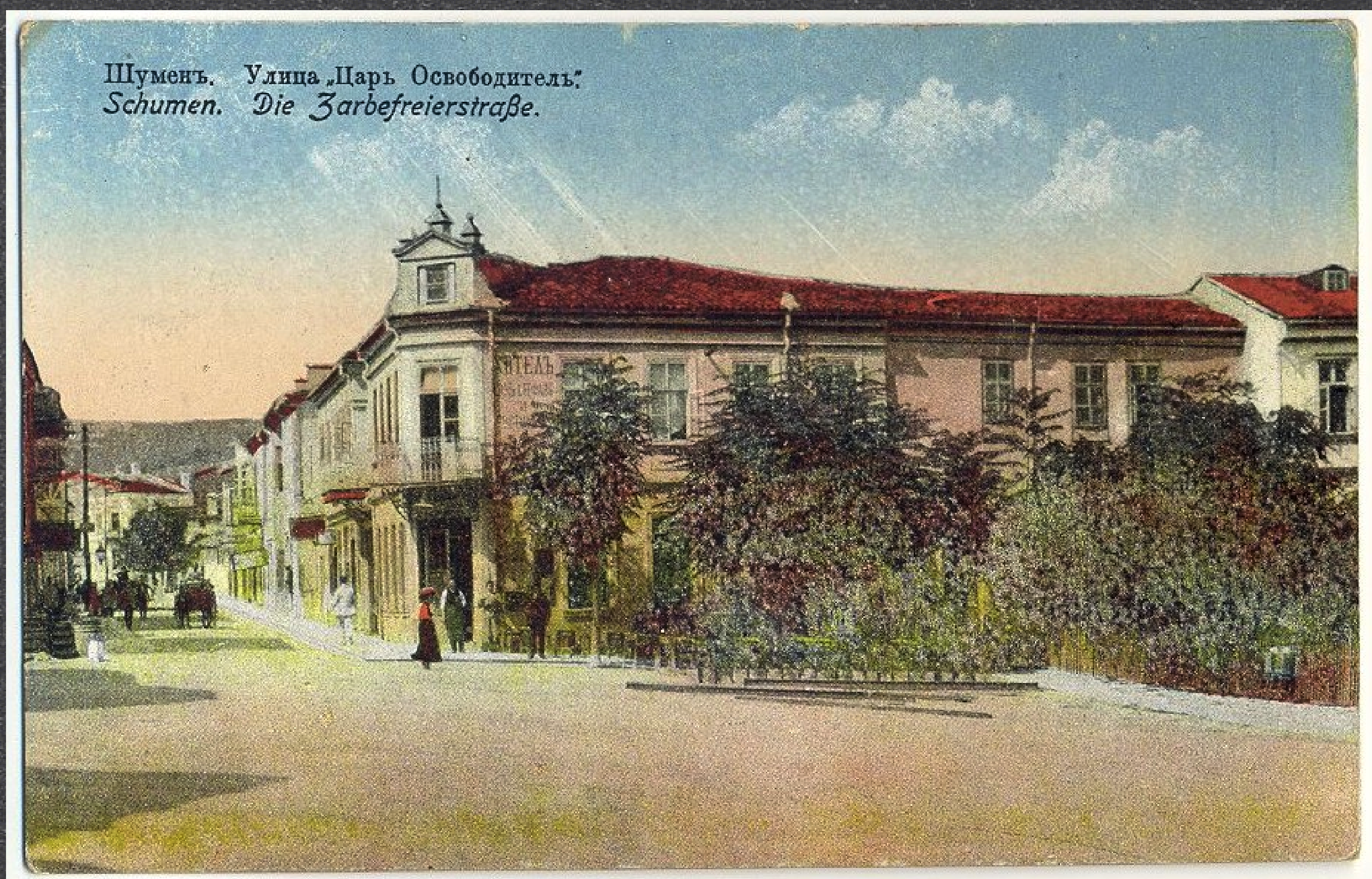

Шуменъ. Улица "Царь Освободитель”. 


\section{Postkarte.}

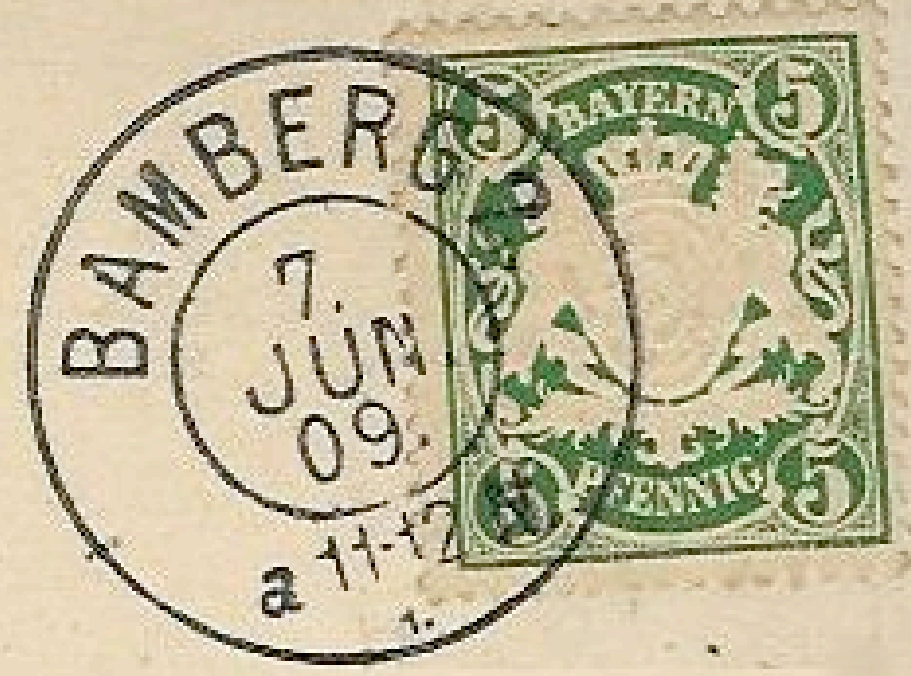

\section{Fehler in der Orthographie}




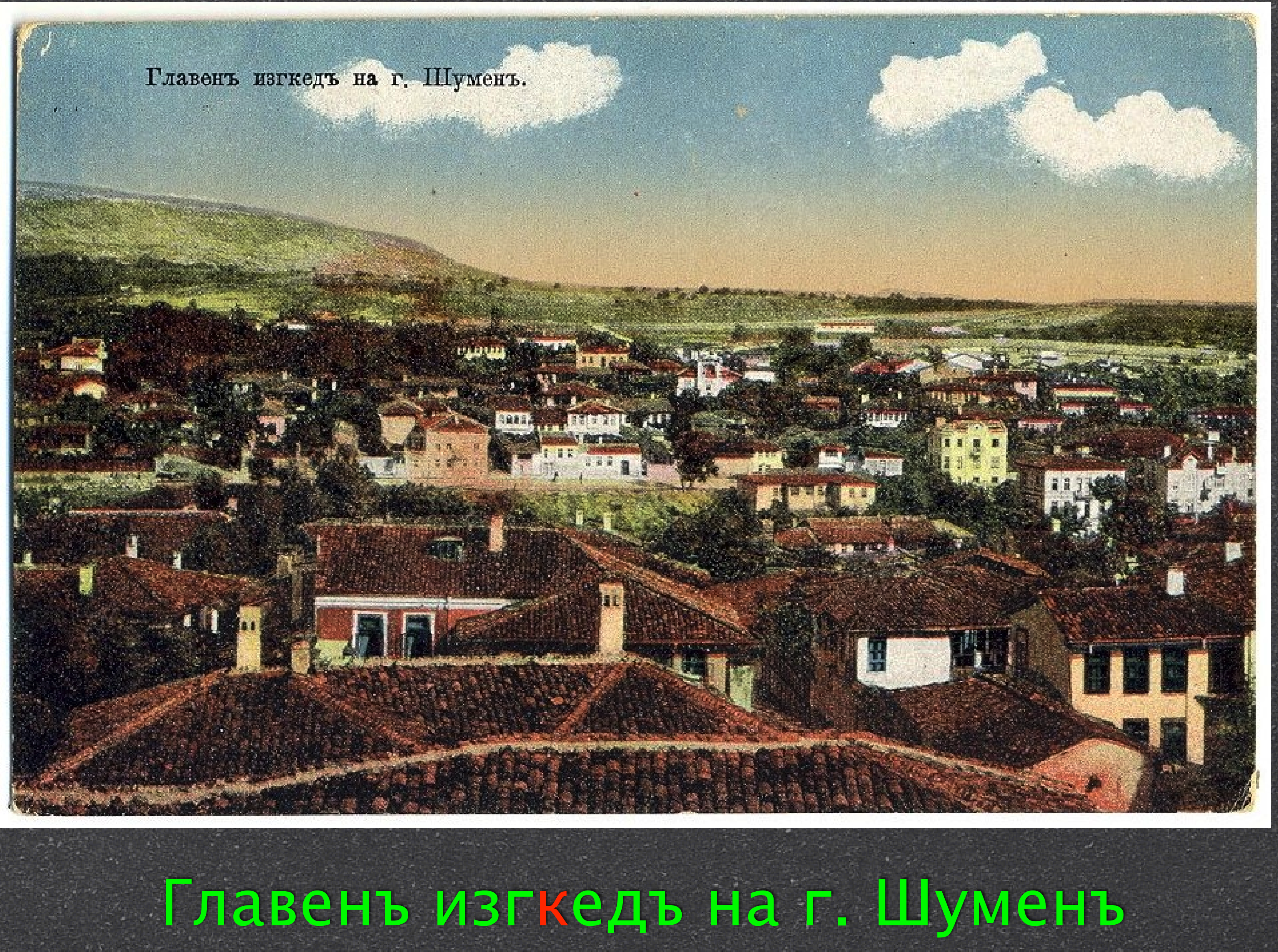




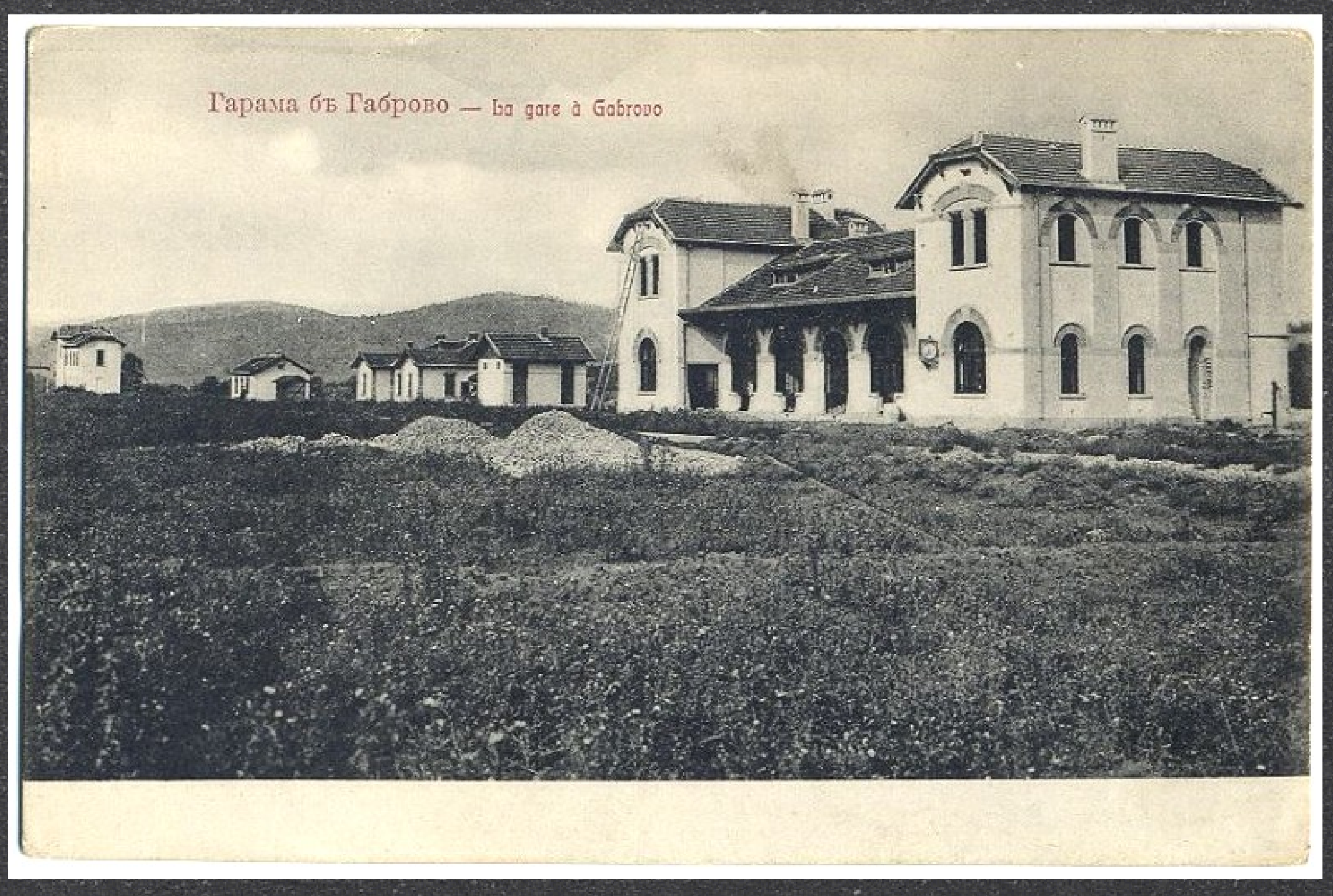

Гарама 6ь Габрово - La gare à Gabrovo 


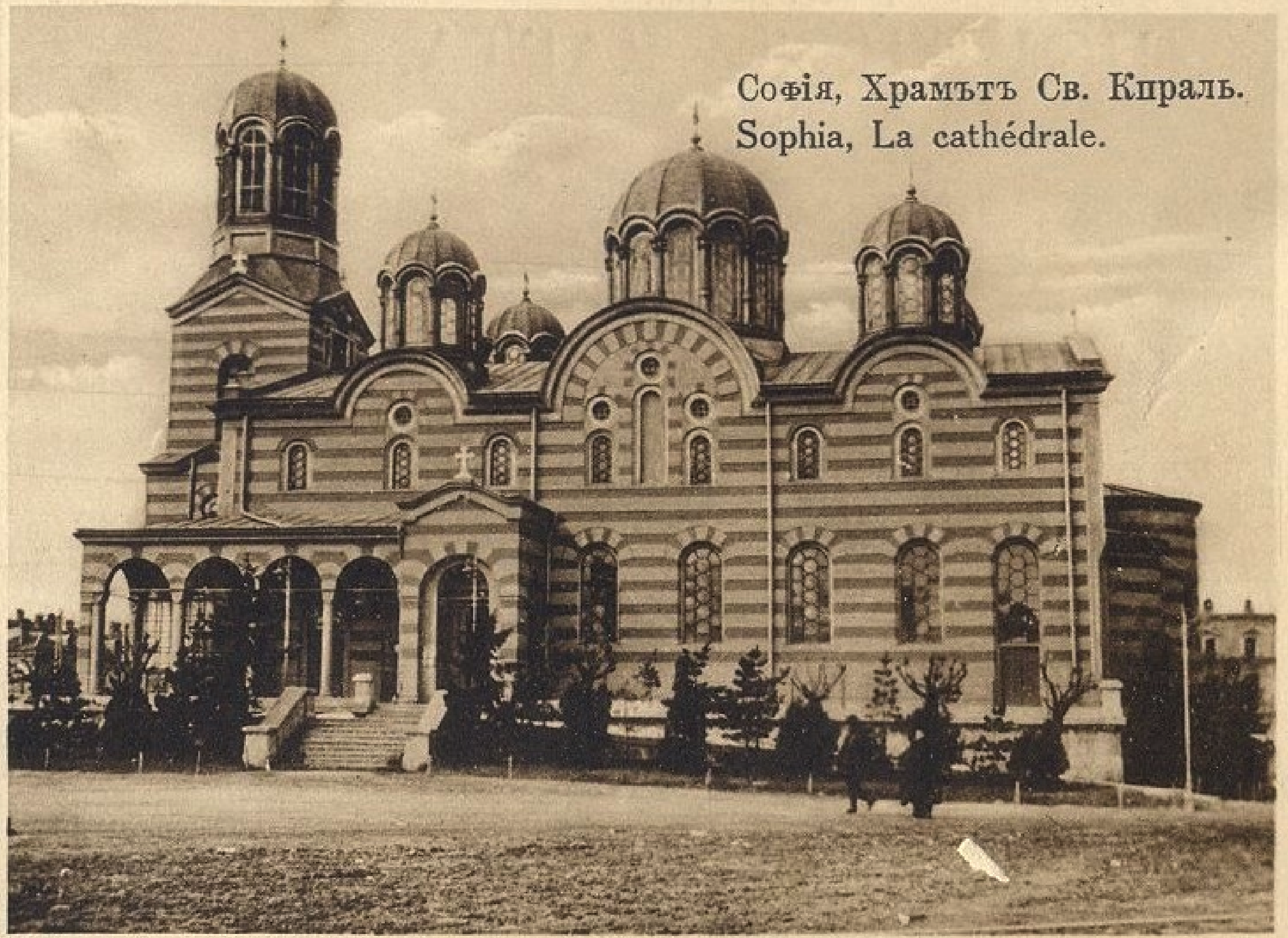

\section{Софія. Храмъть Св. Кпраль.}




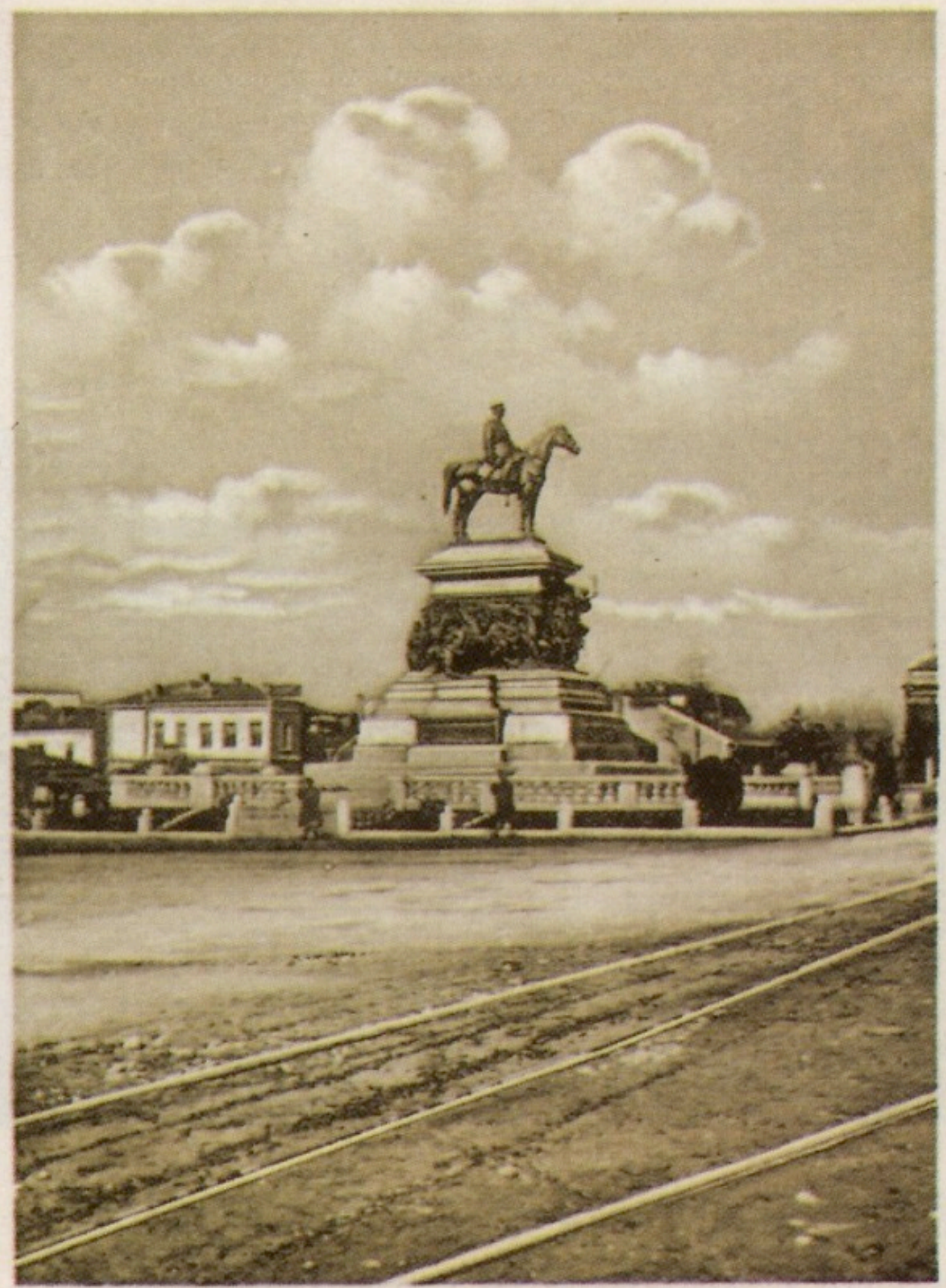

\section{Cофія. \\ Памятник на Царь \\ Освободителя.}

Софія, Памятипкна Царъ Освободителя.

Sophia, Le monument du Tsar-Liberateur.

Сочія, Храмъть Св. Кпраль. : Sophia, La cathédrale. 


\section{Postkarte.}

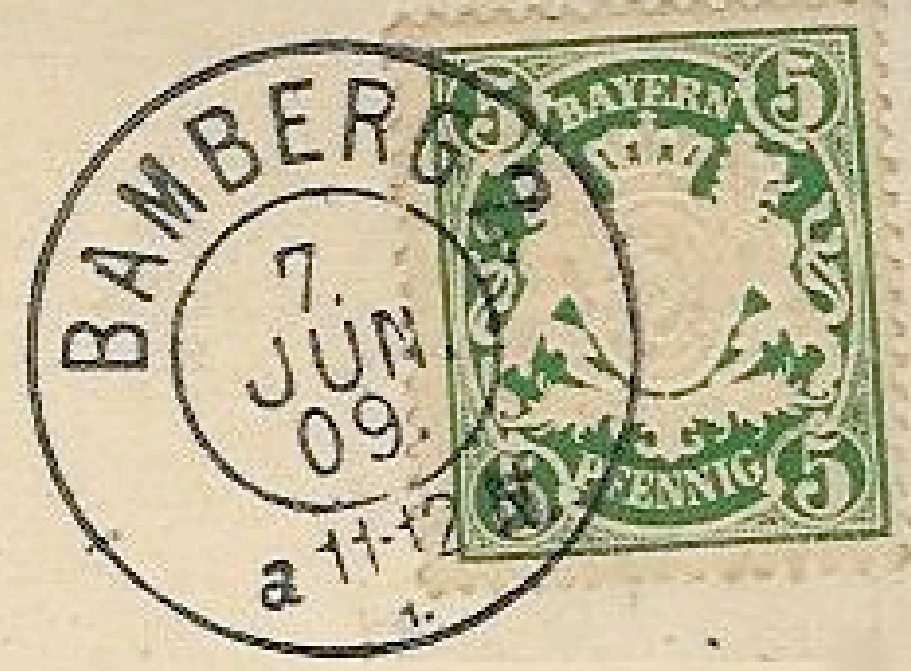

Variation in der

Orthographie 


\section{Изгледъ на, градъ Търново, съ трапезипа}

$\rightarrow$

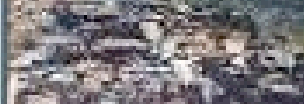

Cos 7.6

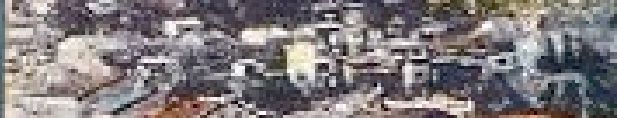

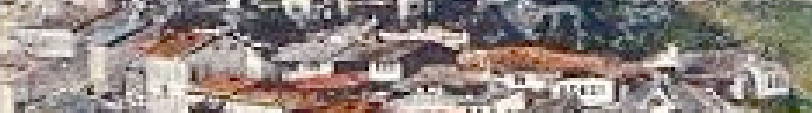

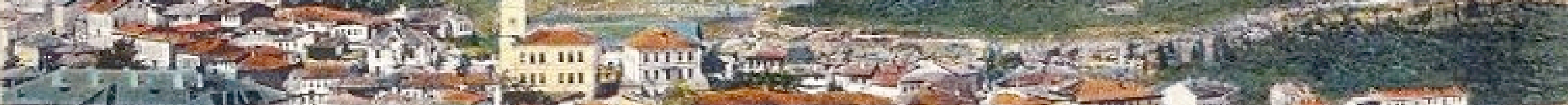
IImin 4 minnin

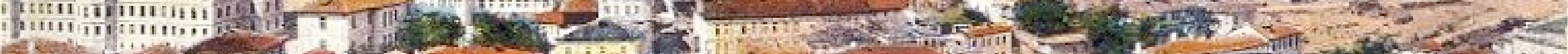

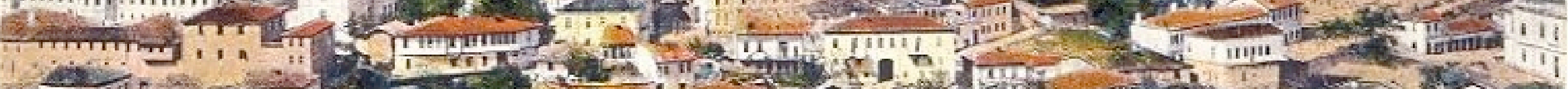
4.

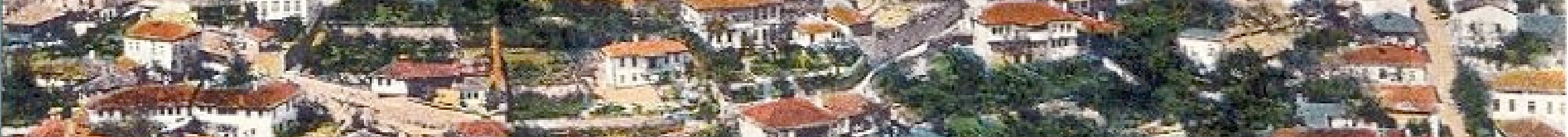

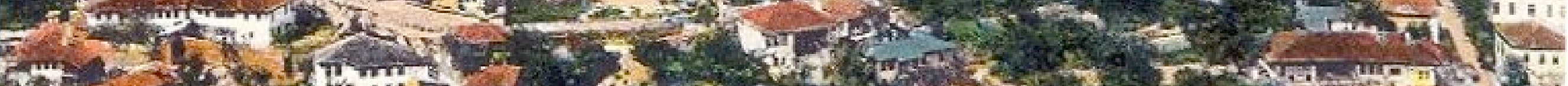

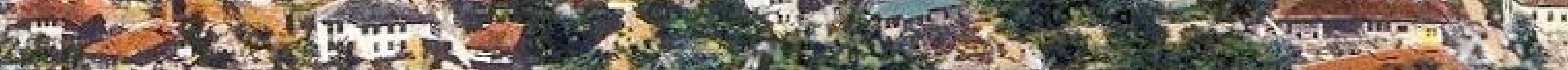

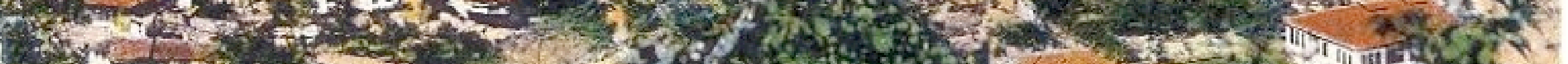
5.5.

Изгледъ на градъ Тьрново, съ трапезица 


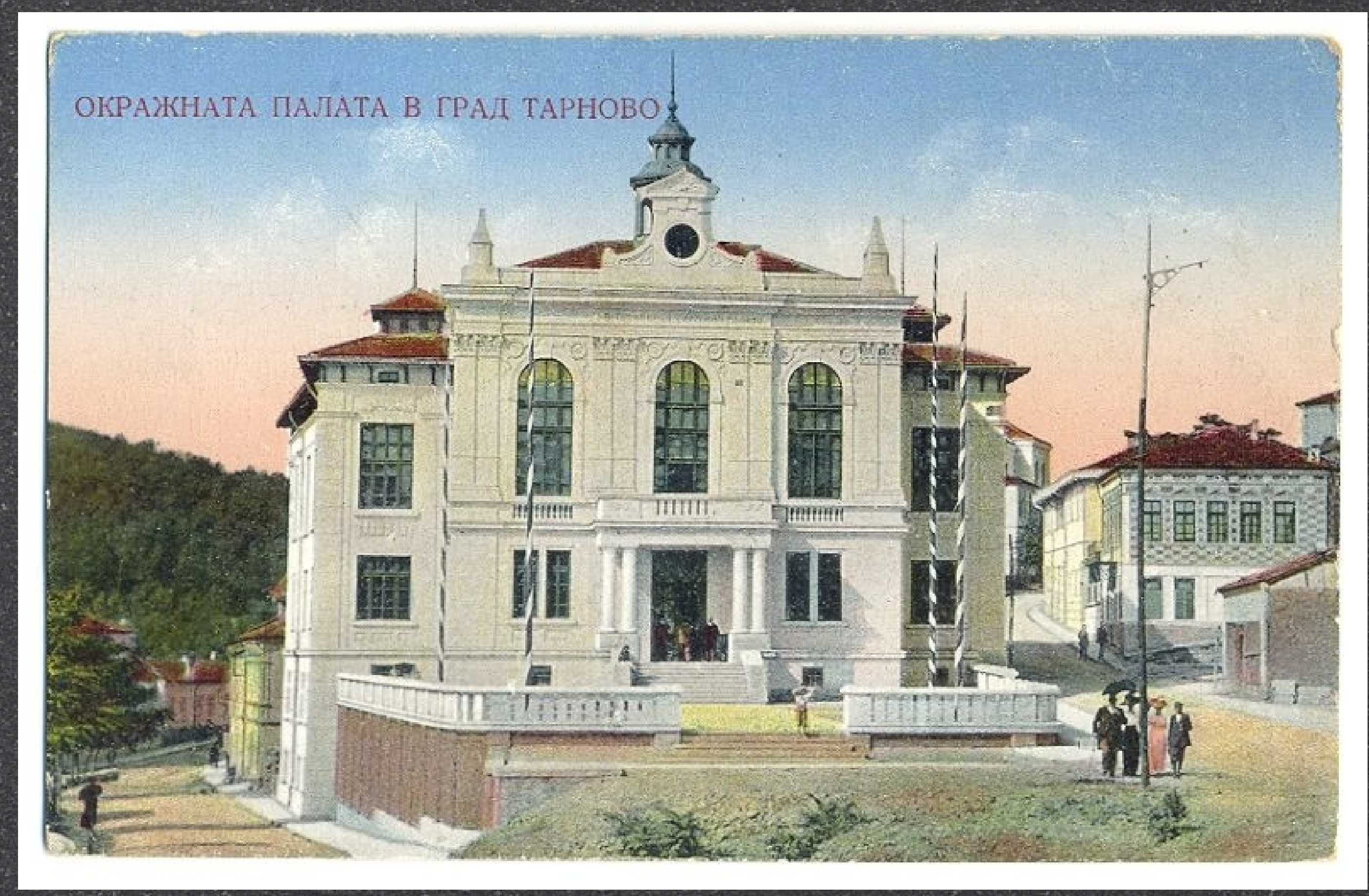

Окражната палата в град Тарново 
Изгледъ на градъ Търново, съ трапезипа
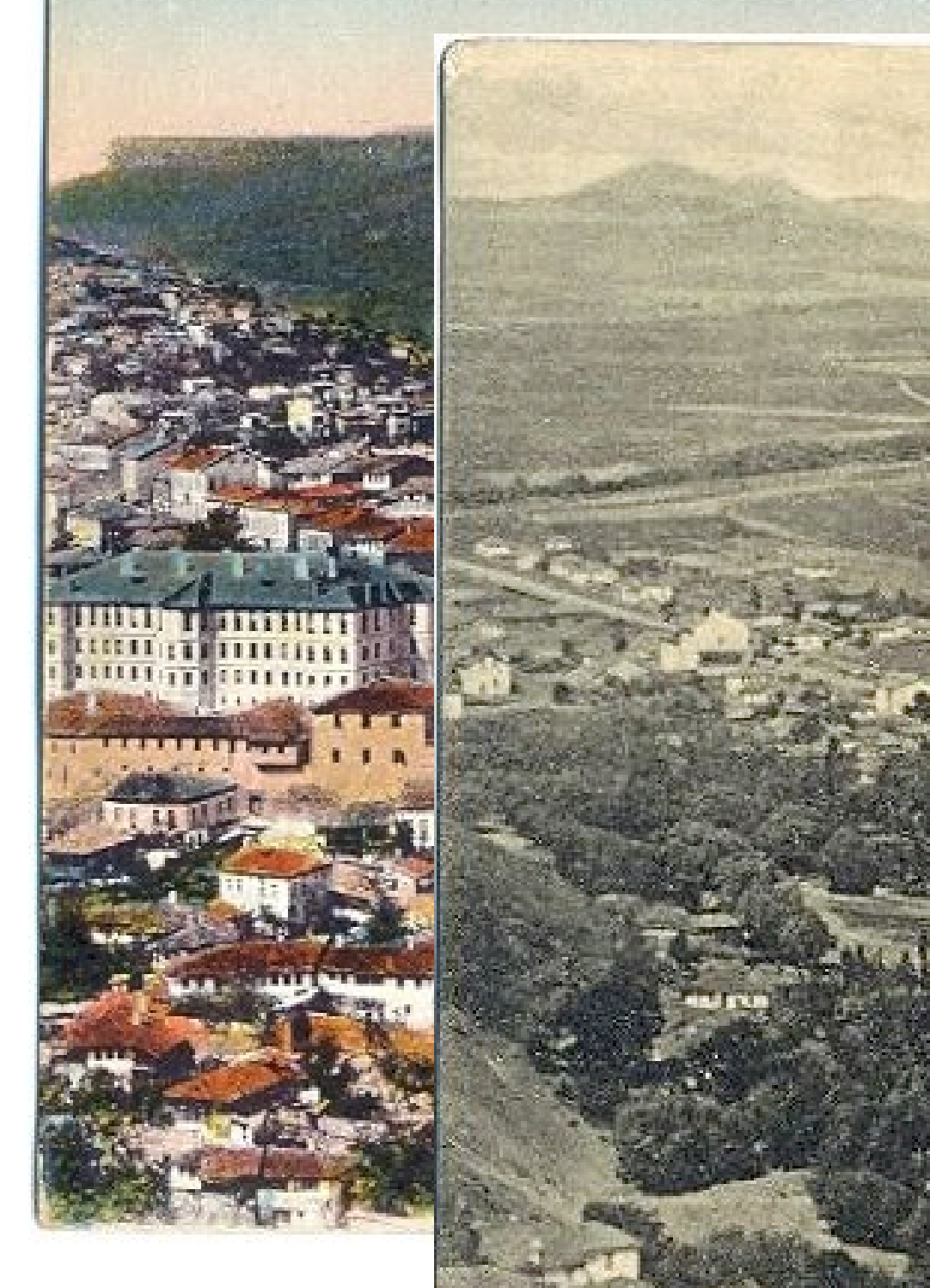

ИЗГ.ЖЛТ, НА ГР. БРБЗНИКЬ

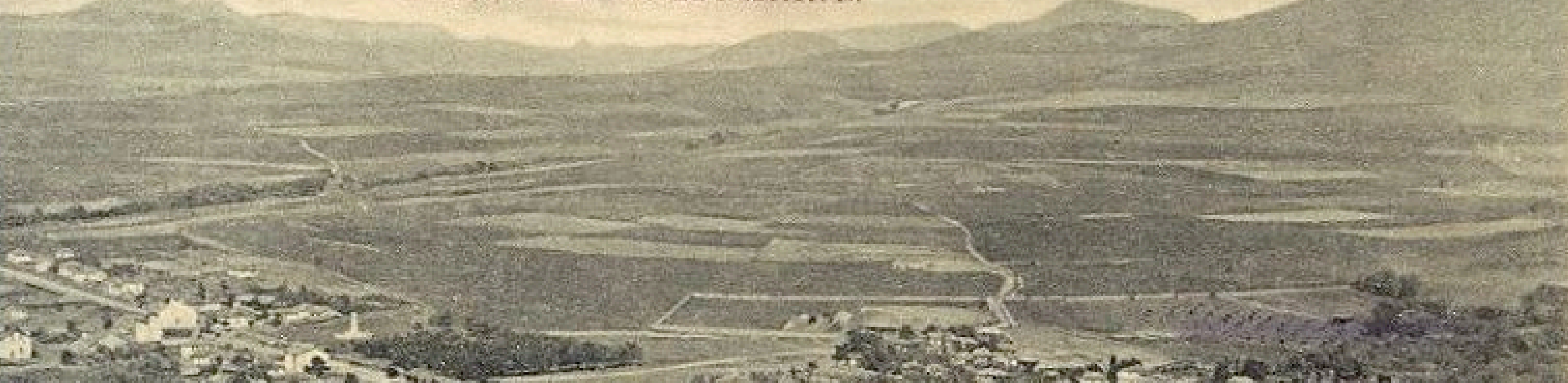

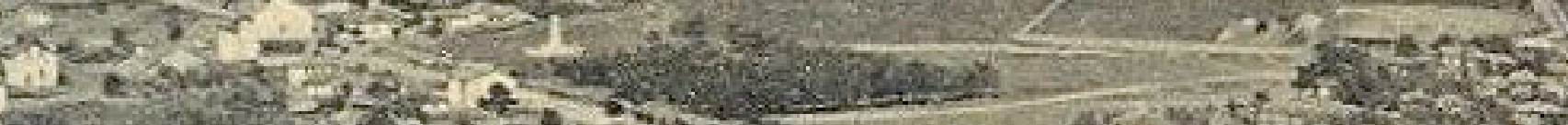

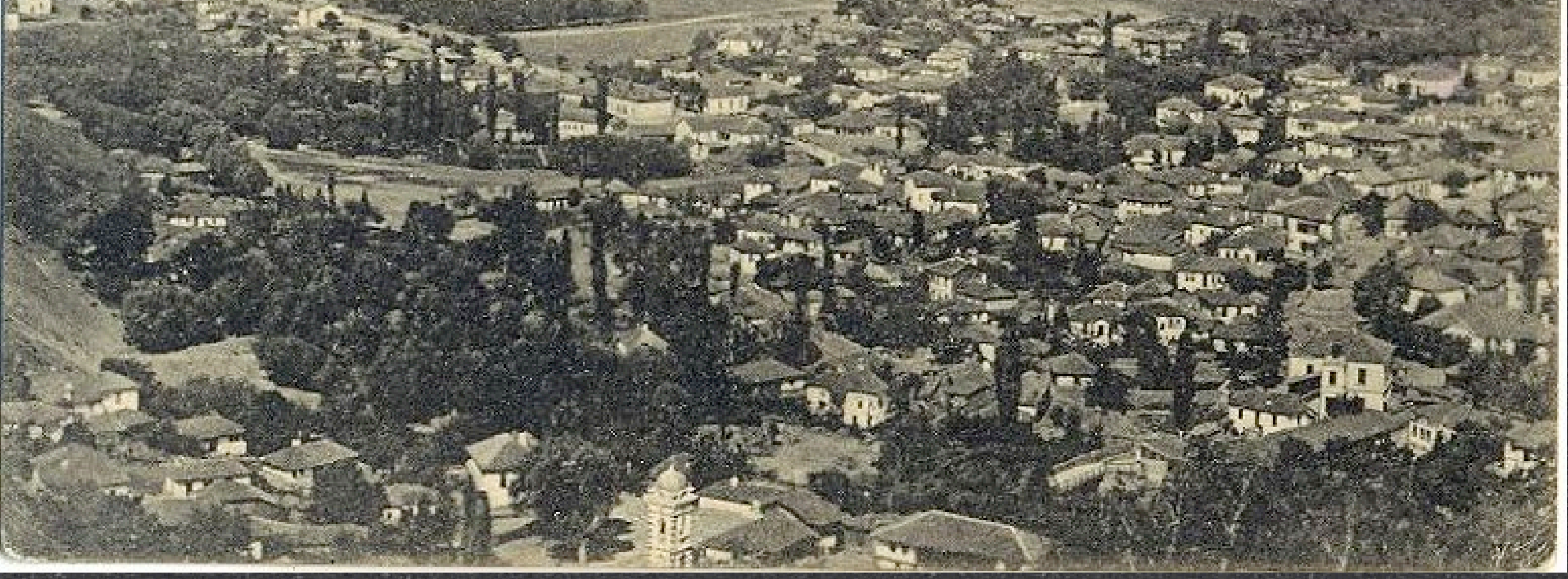

изгледъ - изгльдъ: $25 \mathrm{x} \mathrm{e,} 2 \mathrm{x}$ ь 


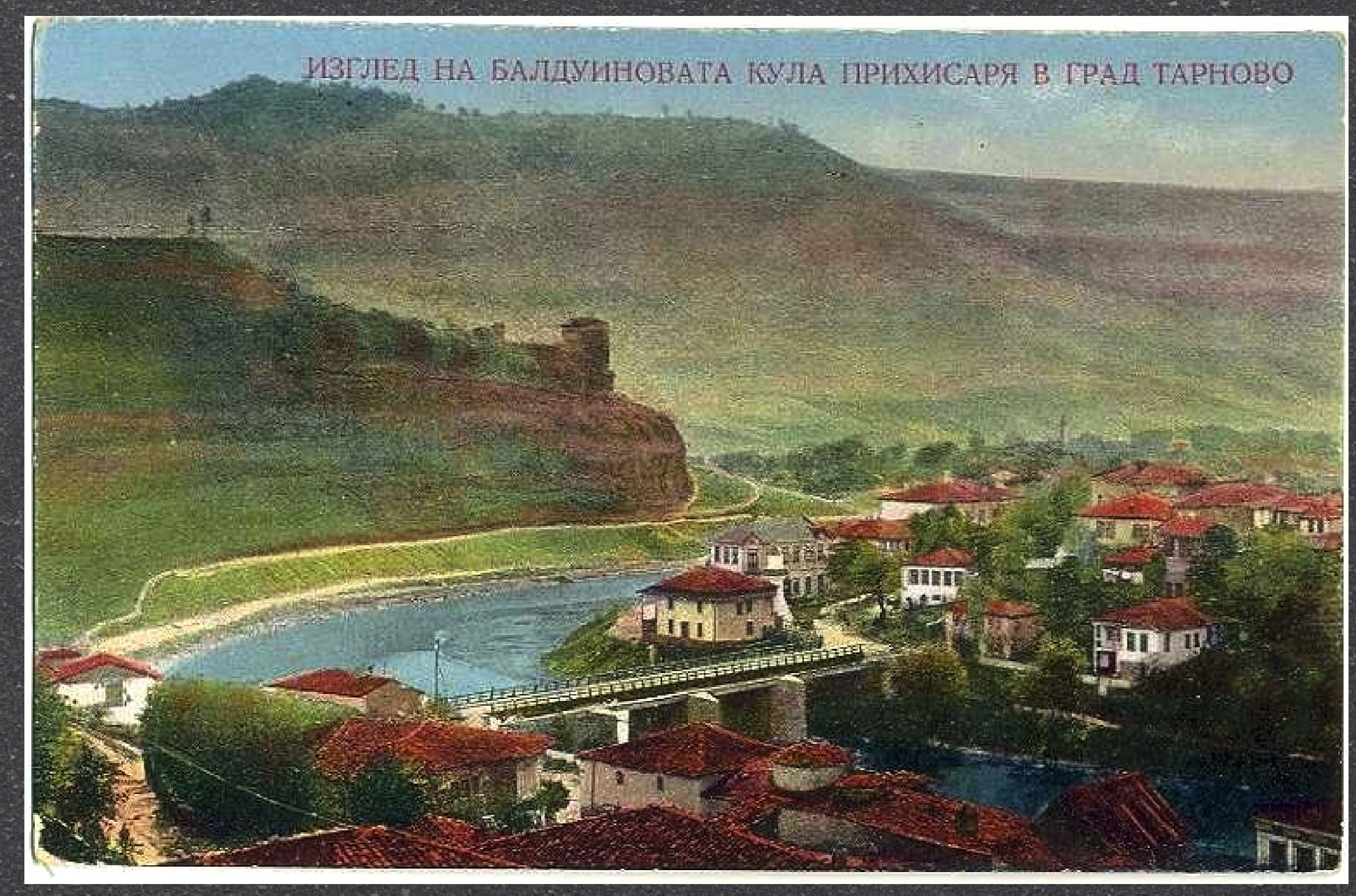

ПРИ ХИСАРЯ, ТАРНОВО 


\section{Postkarte.}

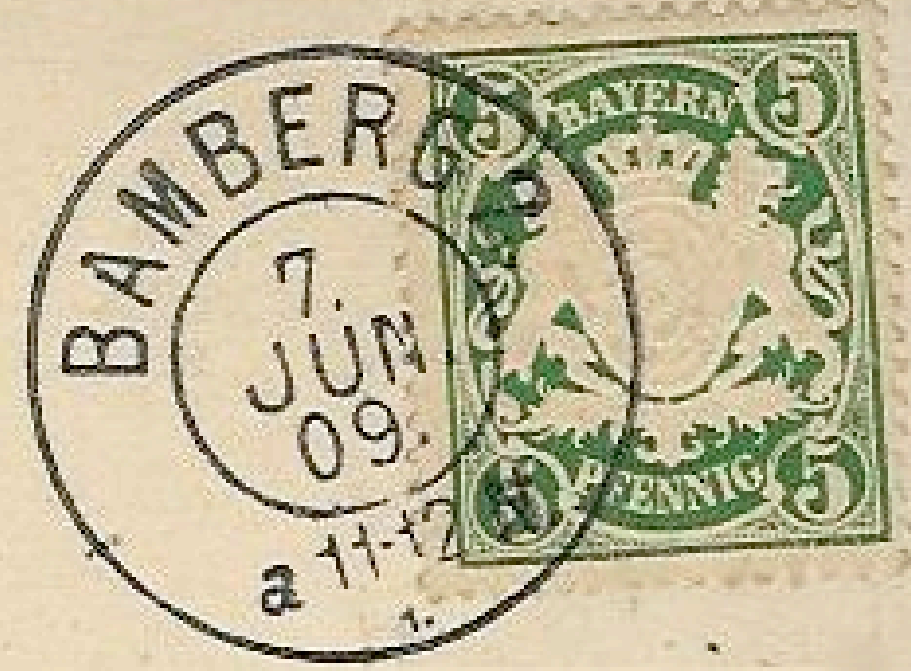

Fehler in der Morphologie des Bulgarischen 


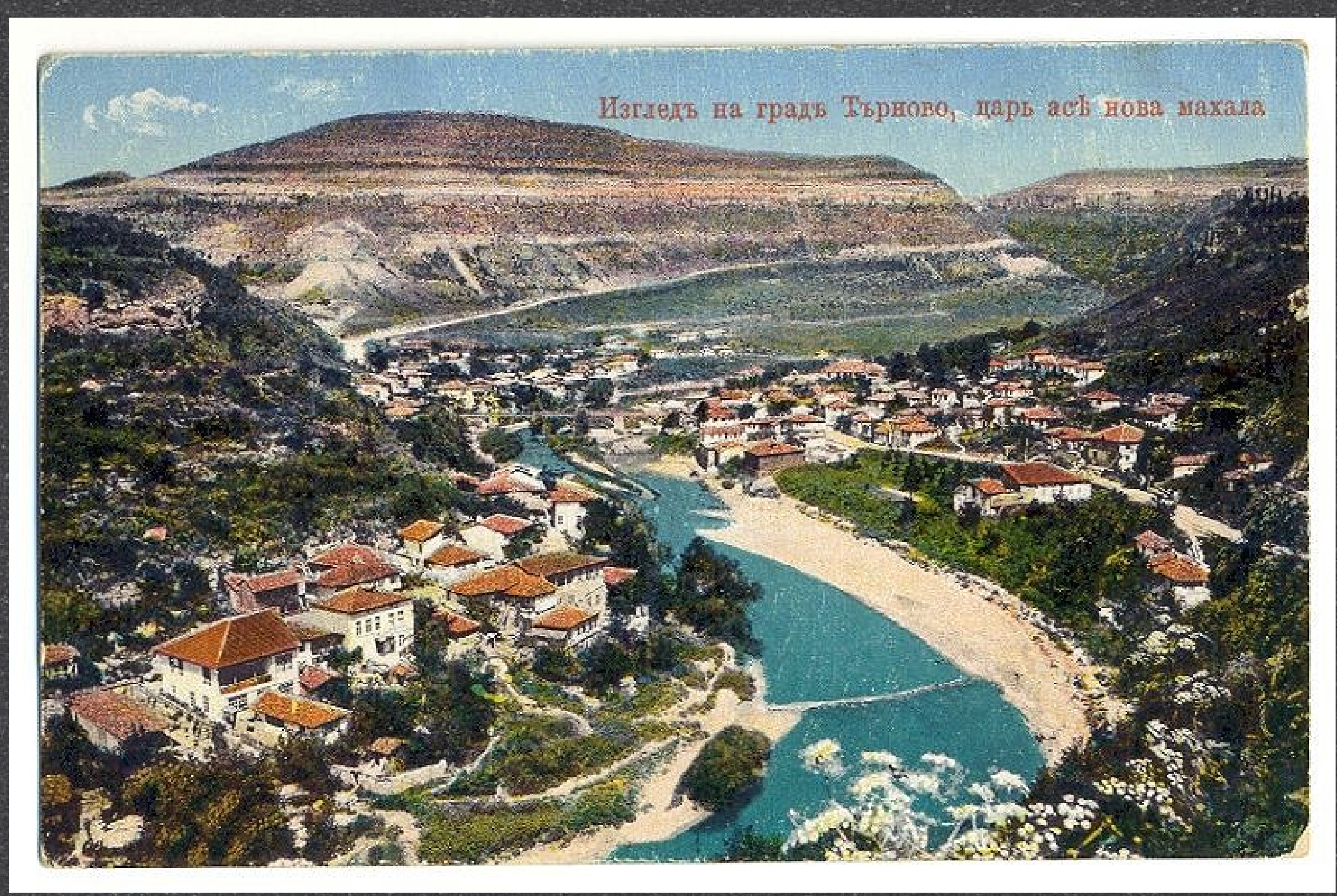

\author{
* царь ась нова махала \\ царь асьнова махала
}




\section{Postkarte.}

Variation in der

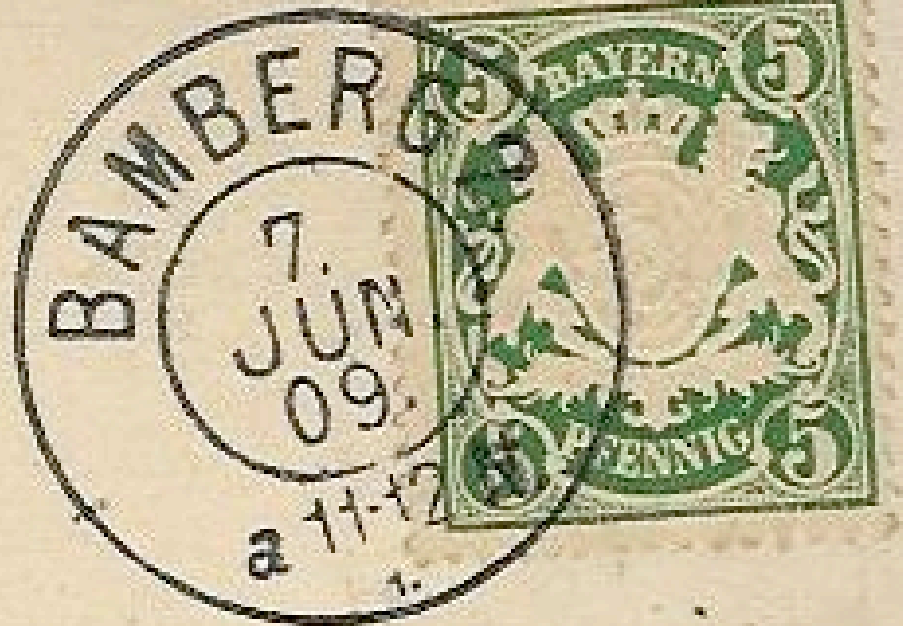

Morphologie des

Bulgarischen (Artikel) 


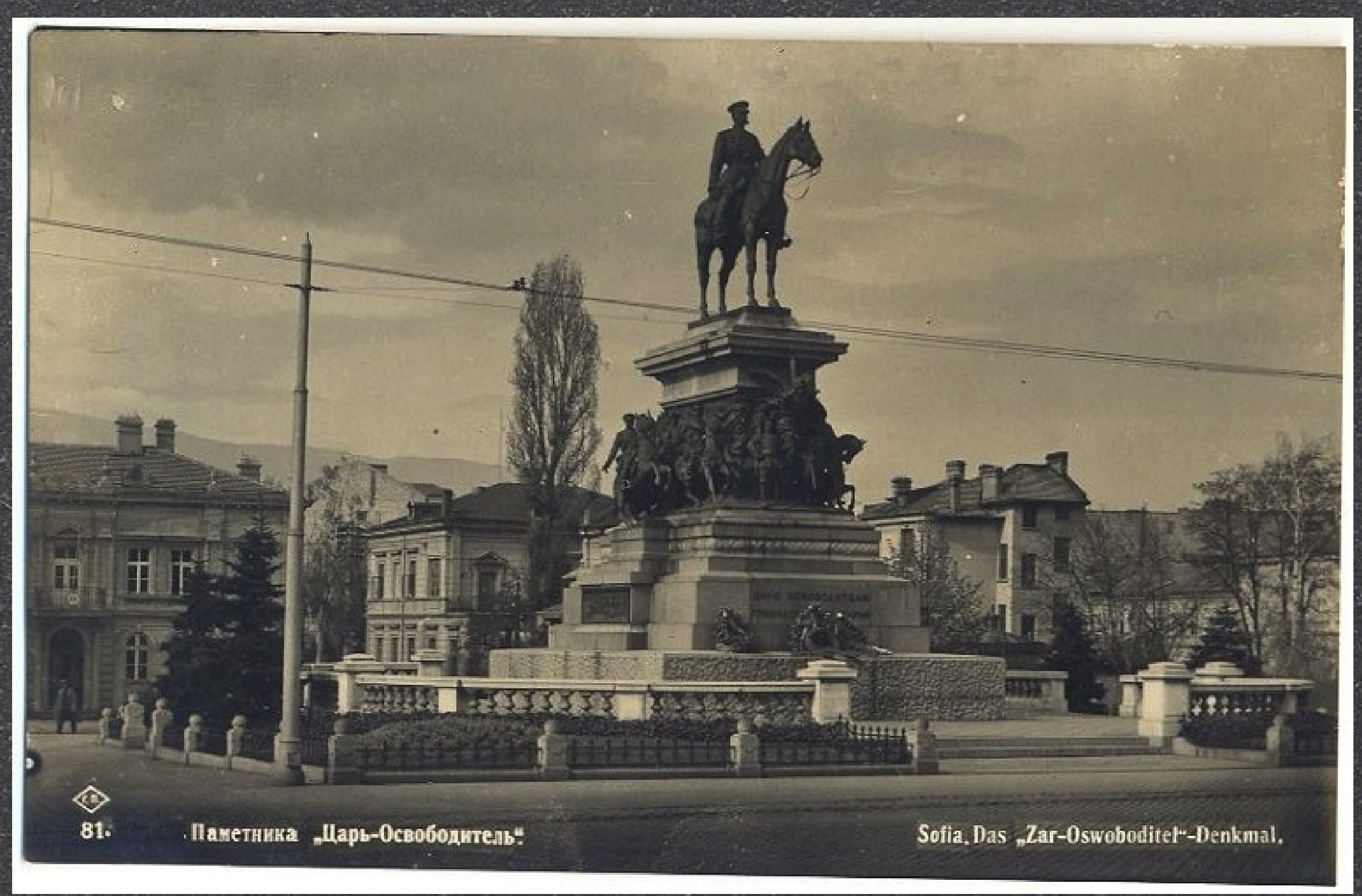

Паметника “Царь-Освободитель”. 


\section{МОСТА МЕЖДУ ХИСАРЯ И СВ. ГОРА В ТАРНОВО}

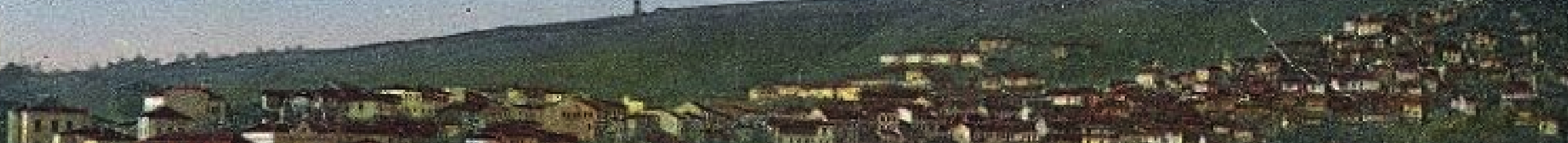

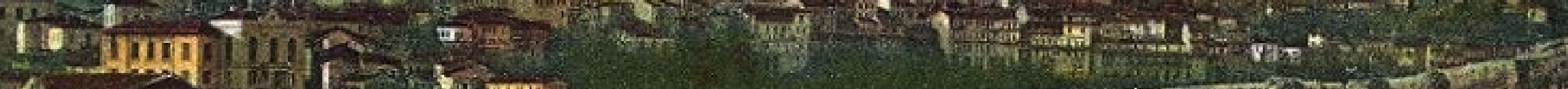

3.

Tob hum

300.

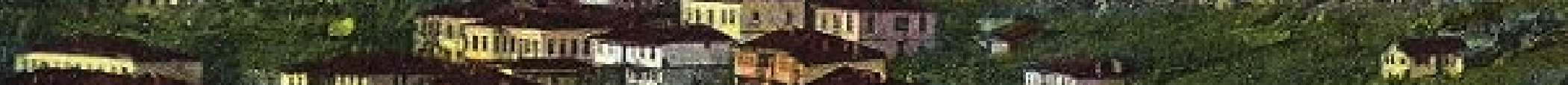

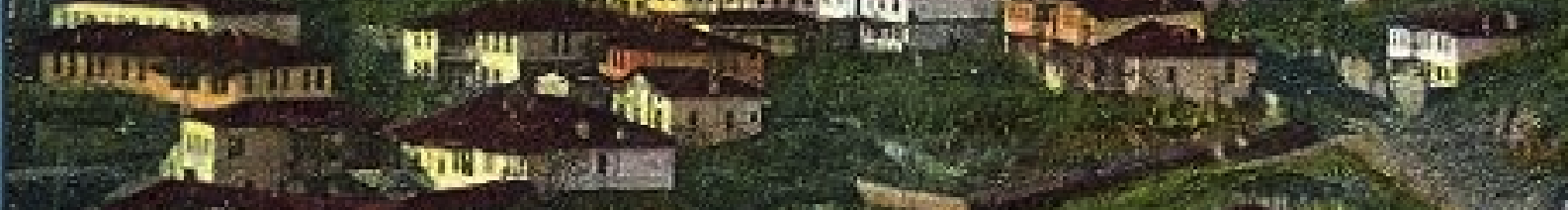

tha

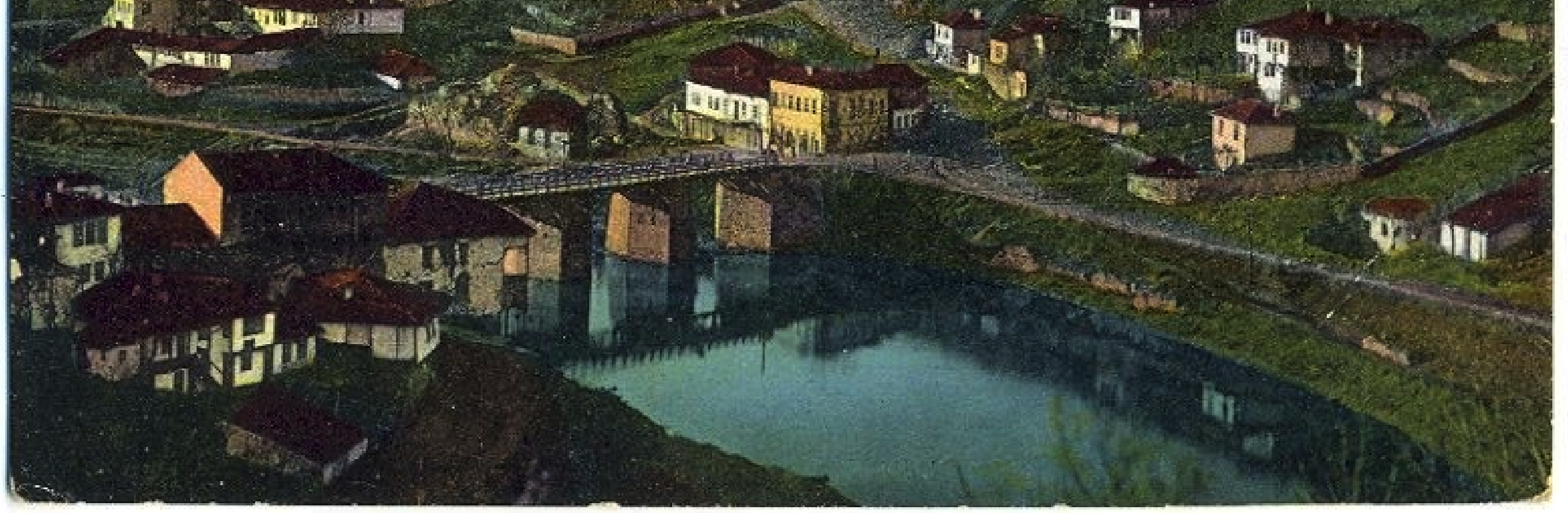

Моста между хисаря и св. гора́ в Тарново 


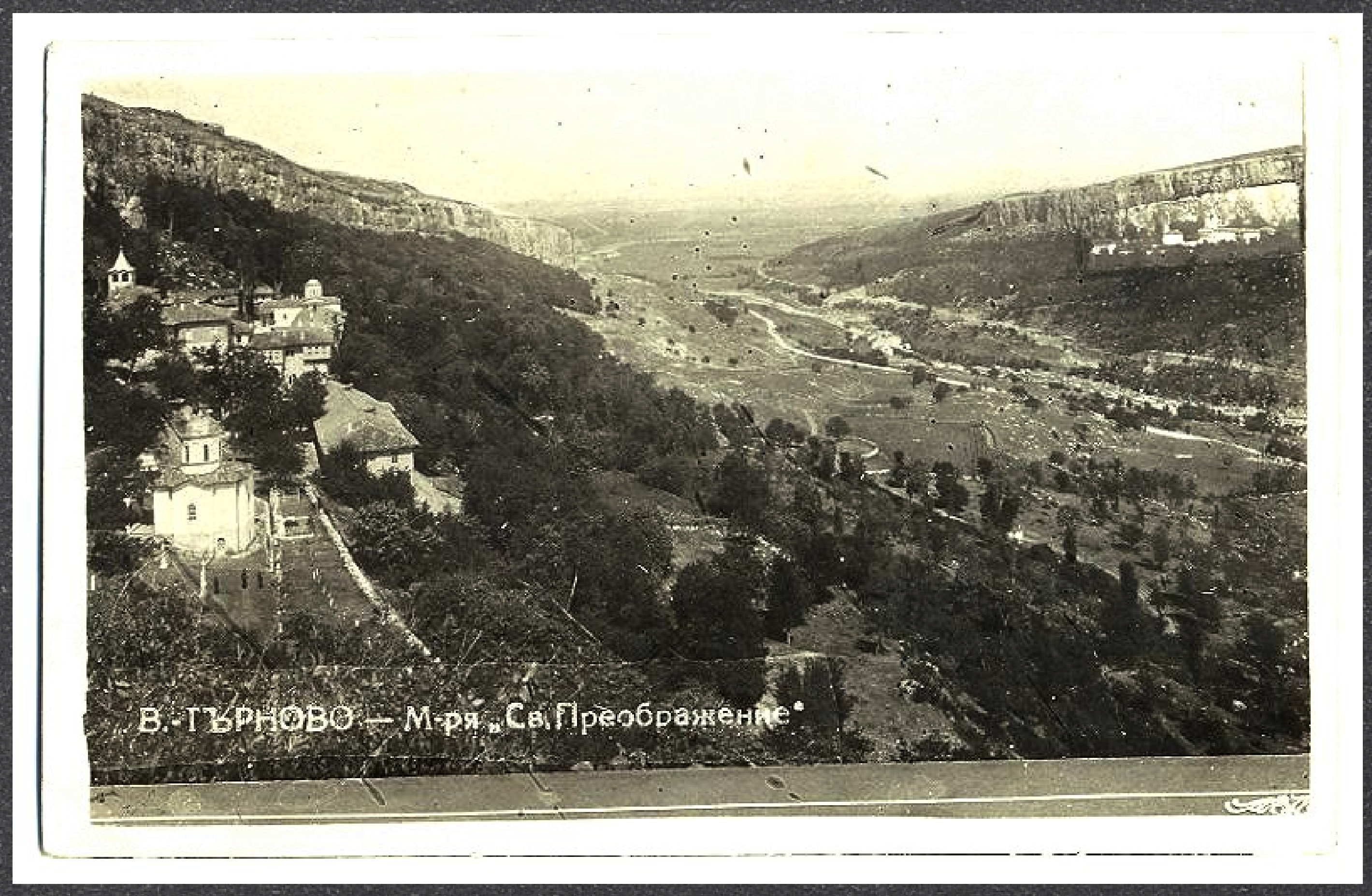

B. Търново -

М-ря "Св. Преображение" 


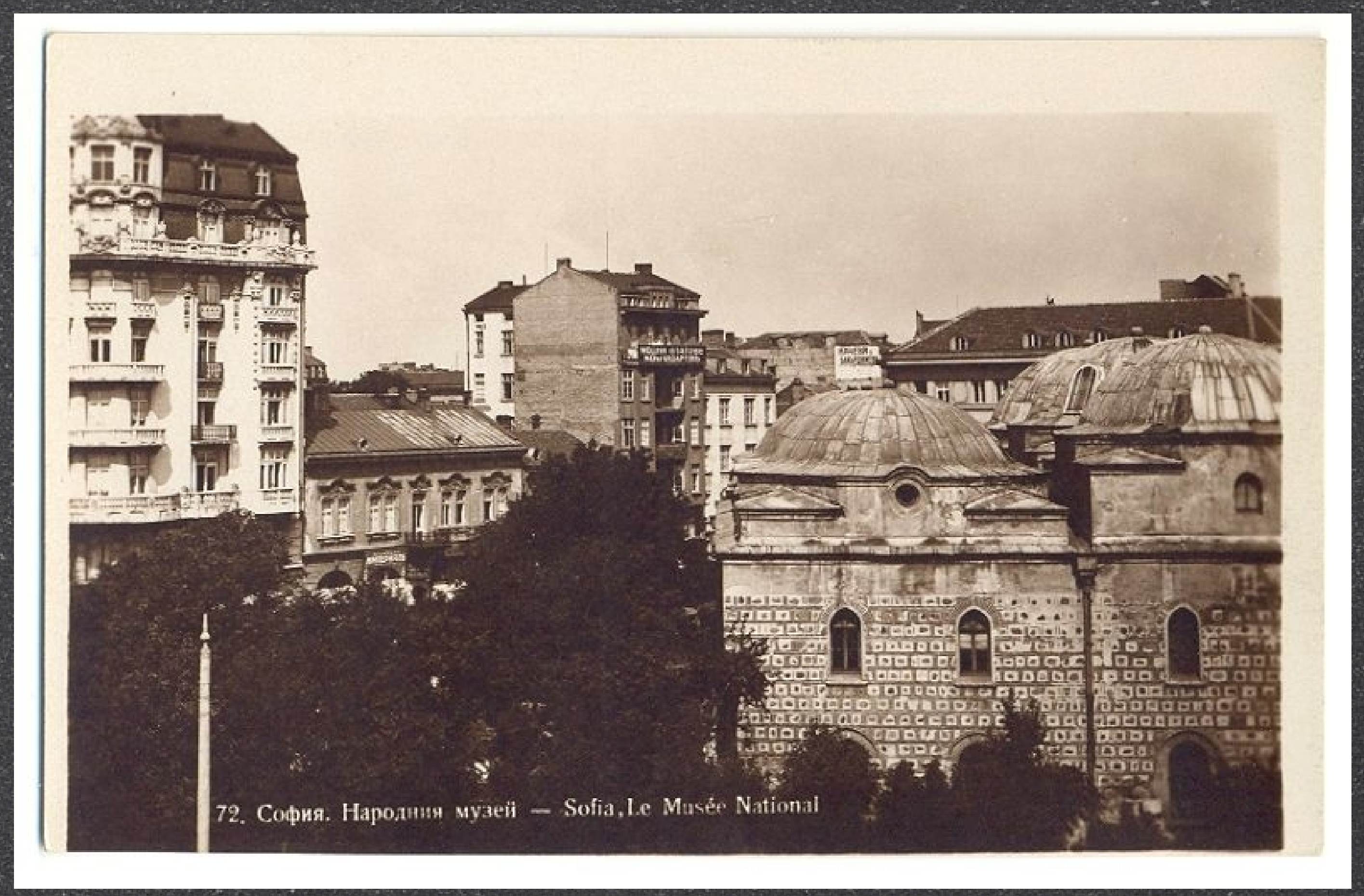

\section{София. Народния музей}




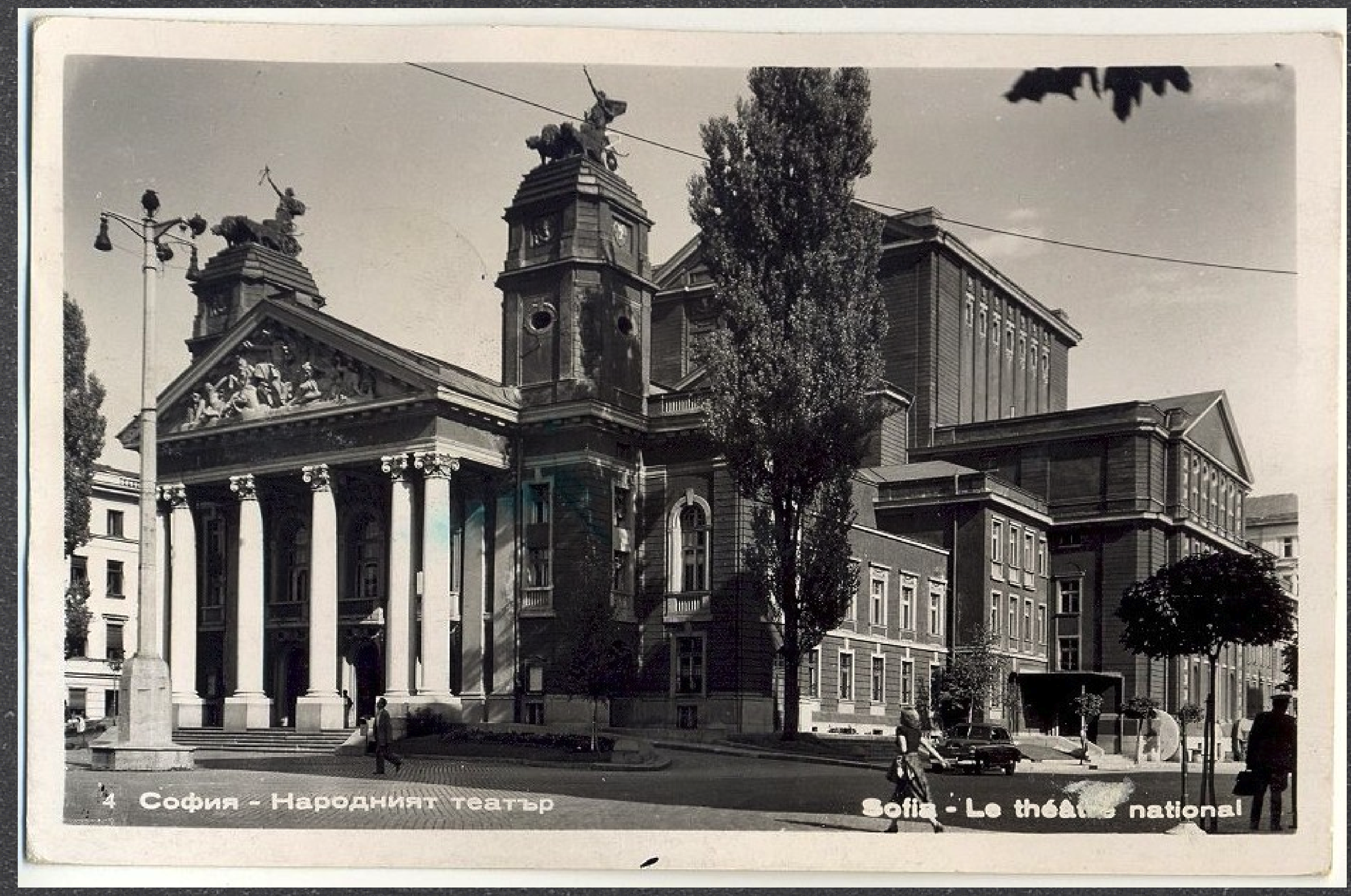

София. Народният театьр 


$$
\text { Postaterte (5) }
$$

Historische Morphologie des Bulgarischen (Flexion) 


\section{Sofia - Zar-Befreier-Denkma!}

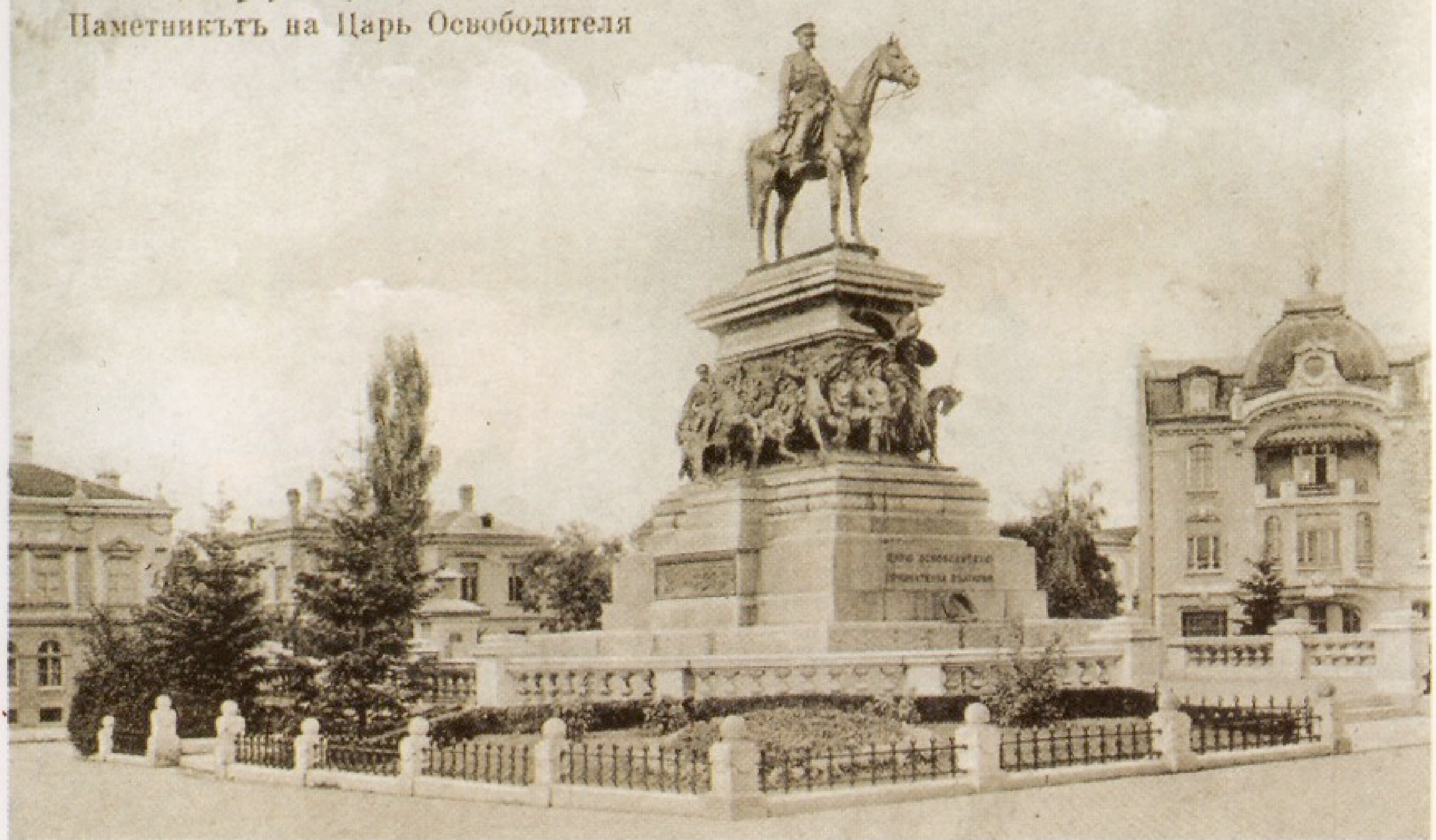

\section{Паметникъть на Царь Освободителя Sofia - Zar-Befreier-Denkmal}




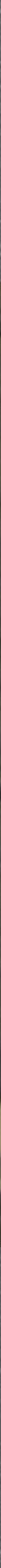


4. За дателенъ падежъ могать да се образуватъ особени форми на $\boldsymbol{y} \boldsymbol{y},-ю$ отъ нБкои сжществителни, главно лични собствени и нарицателни имена (само въ един ст ве но число): Богъ - Богу, Стоянб - Стояну. Петко - Петку, народь - народу, господинъ - господину, ратай — ратаю, човюкв - човпку.

Въ днешно време тая форма се замьня съ съчетание отъ предлога на и основната или винителна фсрма на сжществителното: кажи на Стоянв (кажси на Стояна), на Петко (на Петка), на никой човпкъ.

\section{Л. Андреичин, Основна българска граматика, София 1942, 137-138}




\section{Postkarte.}

Sprachpolitik

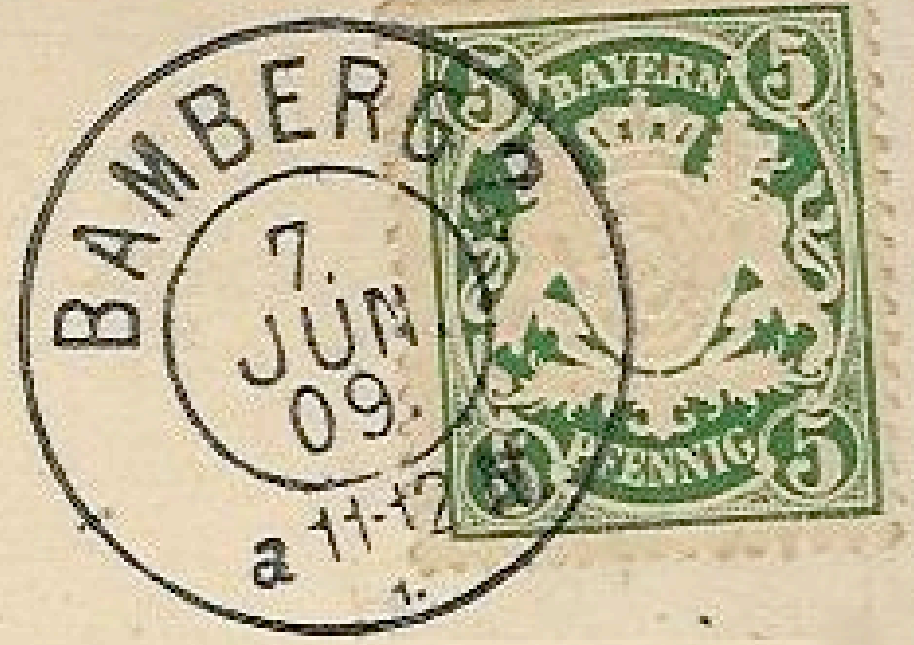

Sprachpurismus

- Eliminierung türk.

Namen 


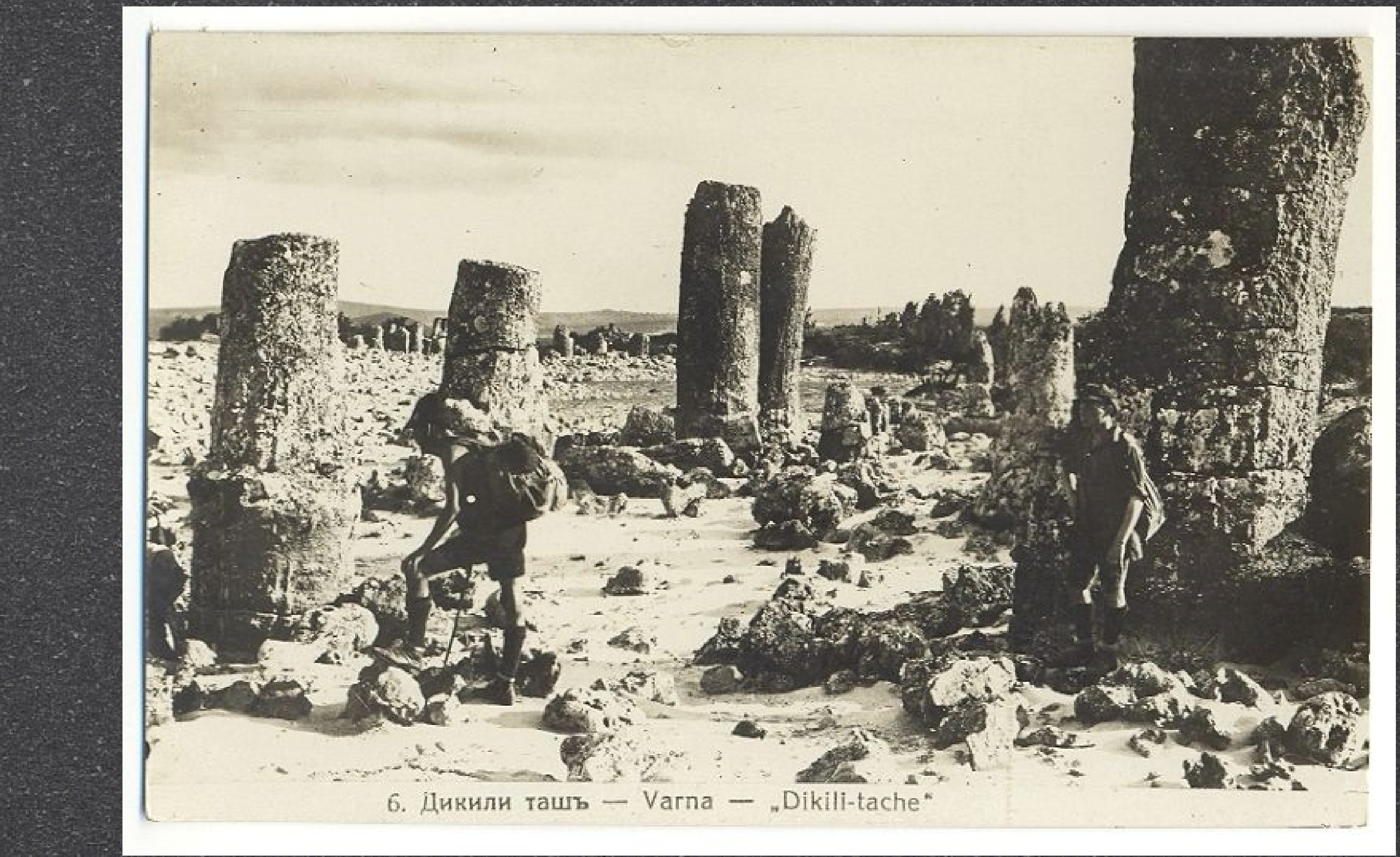

\section{Дикили ташъ - Varna - "Dikili-tache" ('Stehende Steine', türk.)}




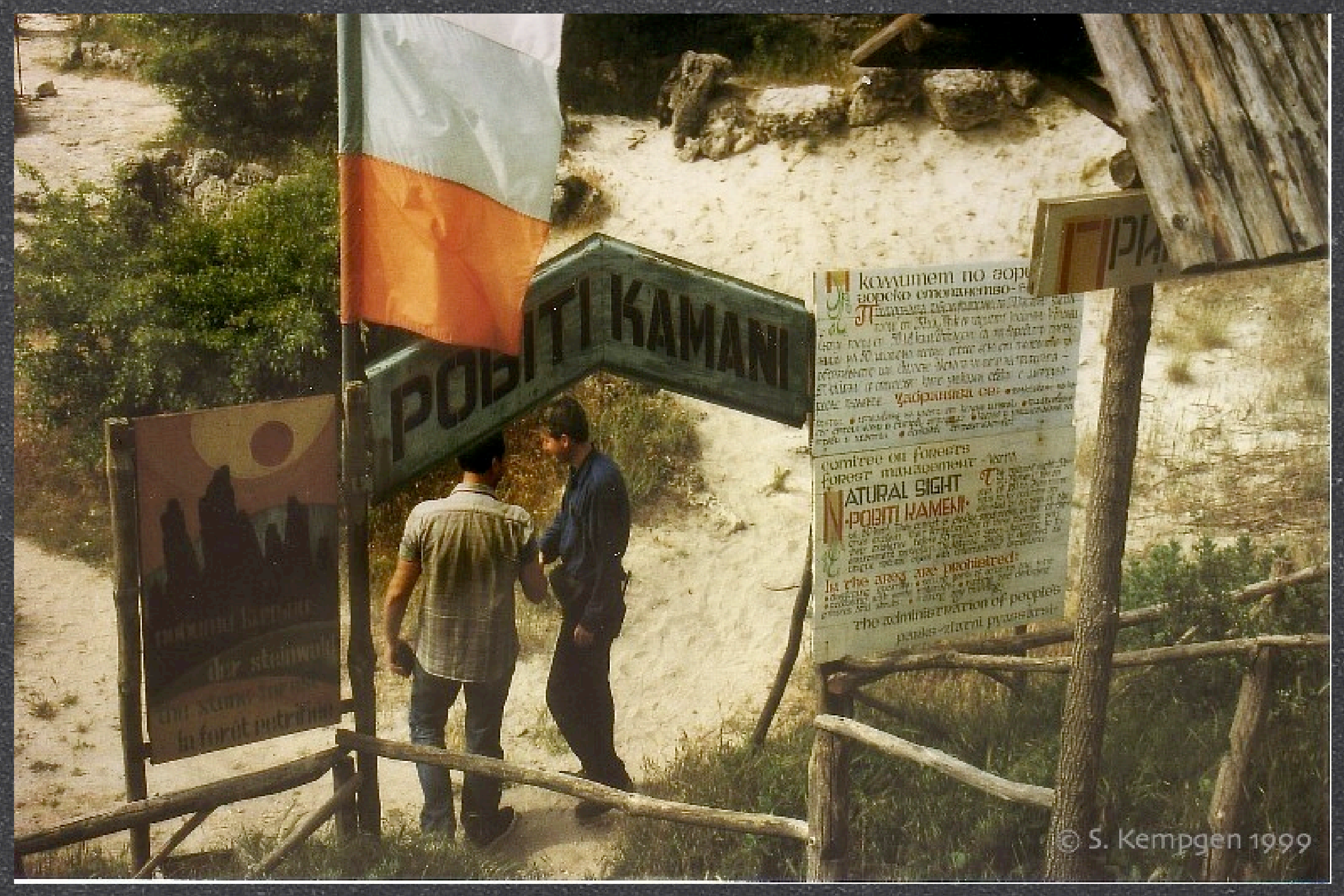

Побити Камъни, Побитите Камъни 


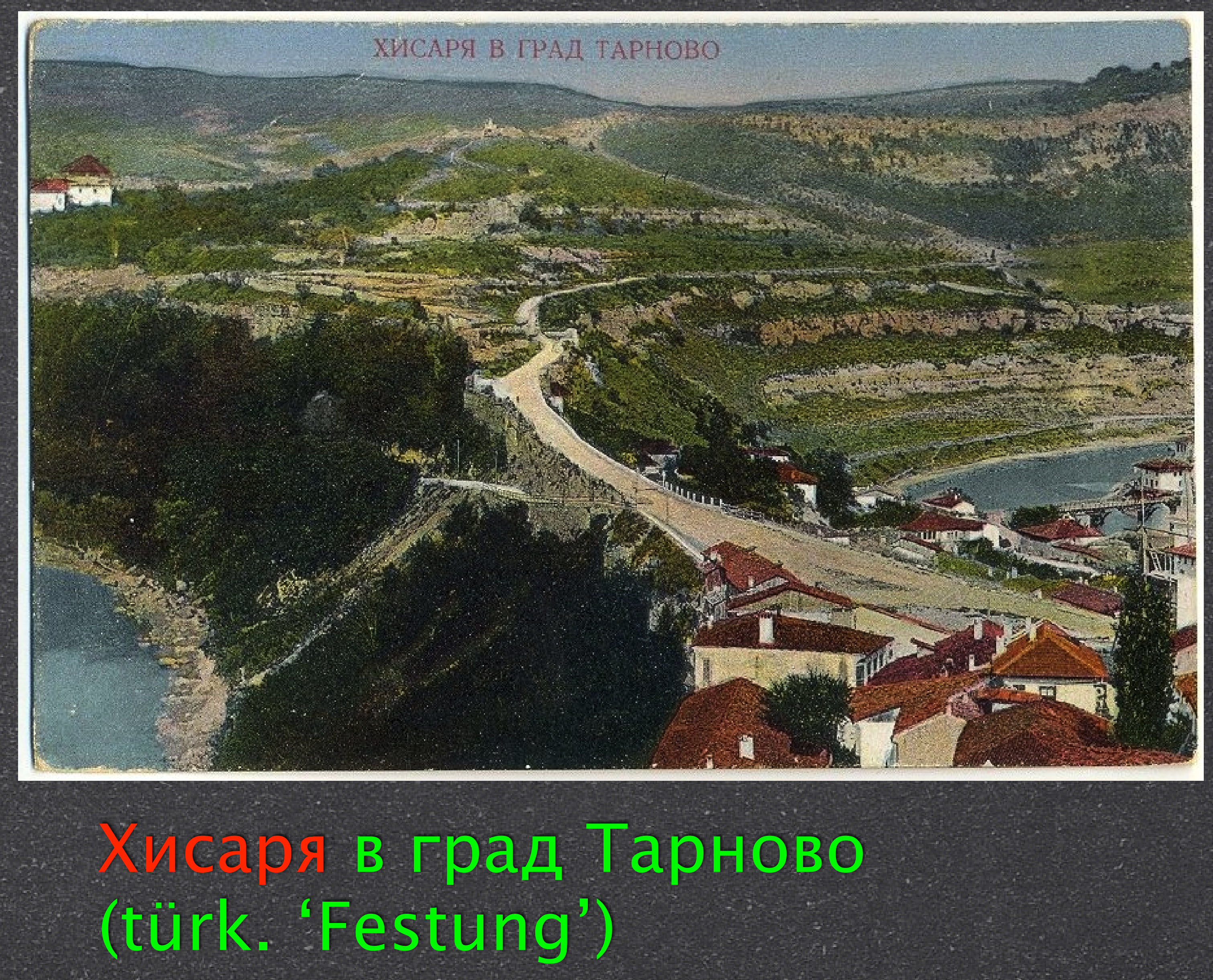




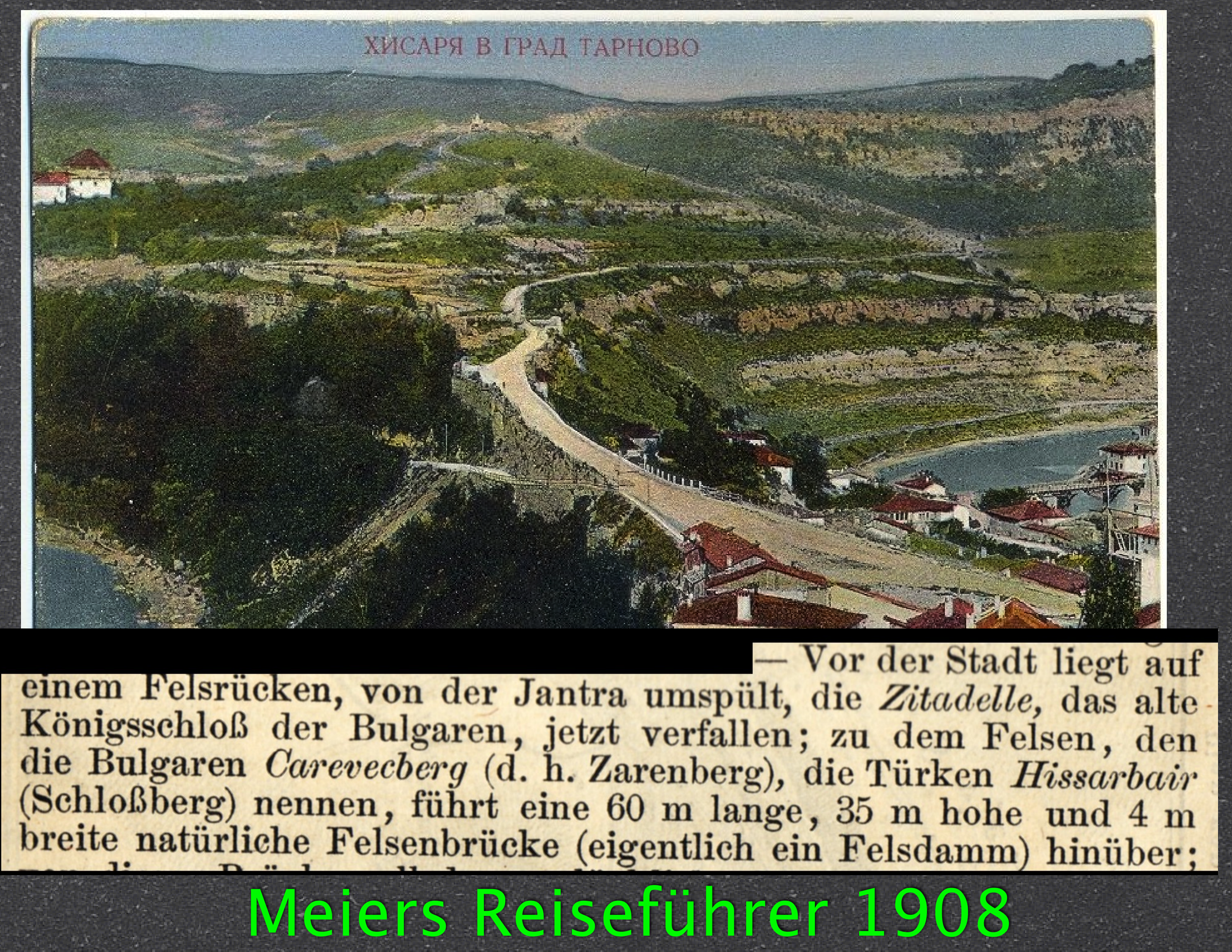




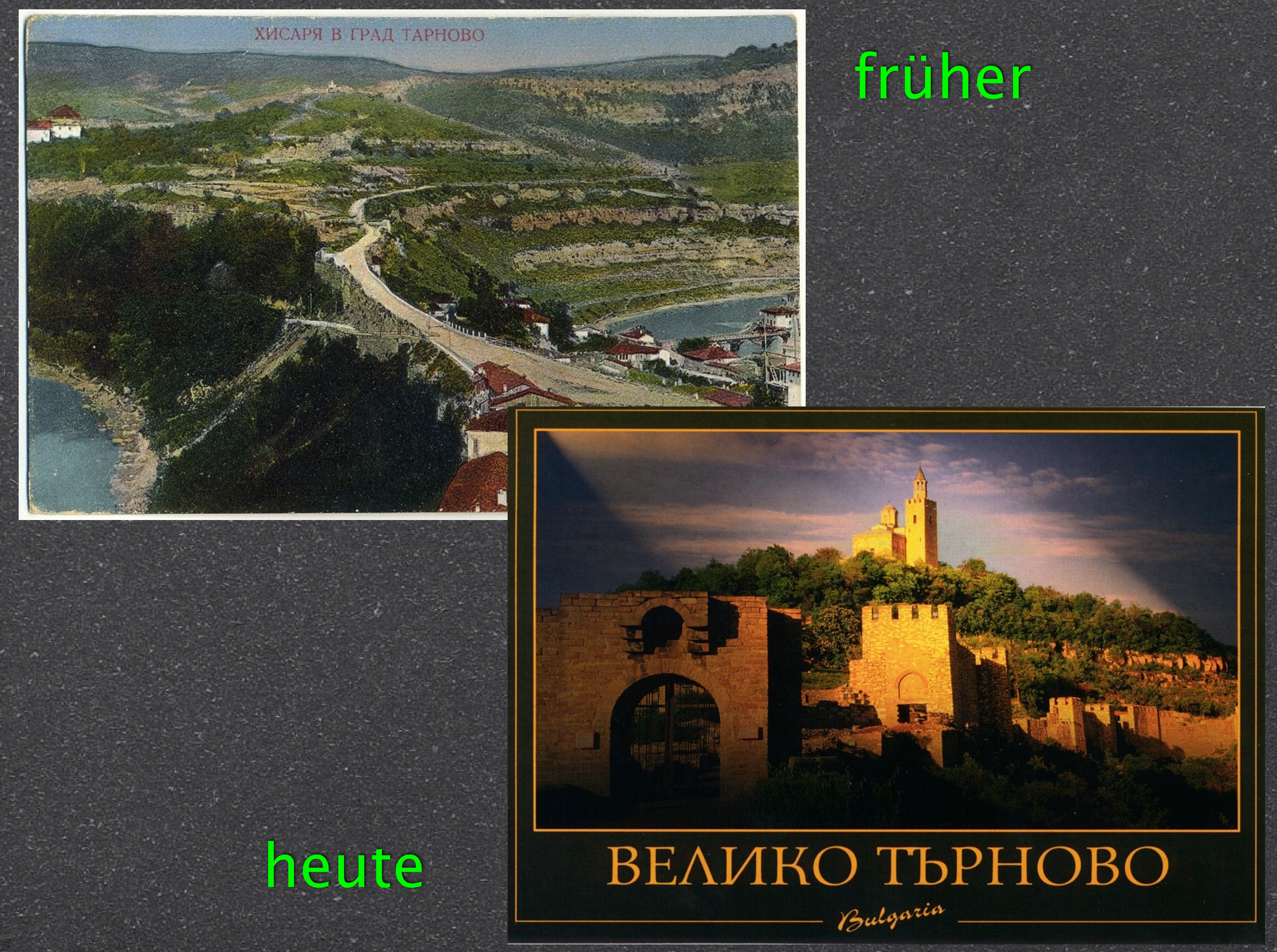




\section{Postkarte.}

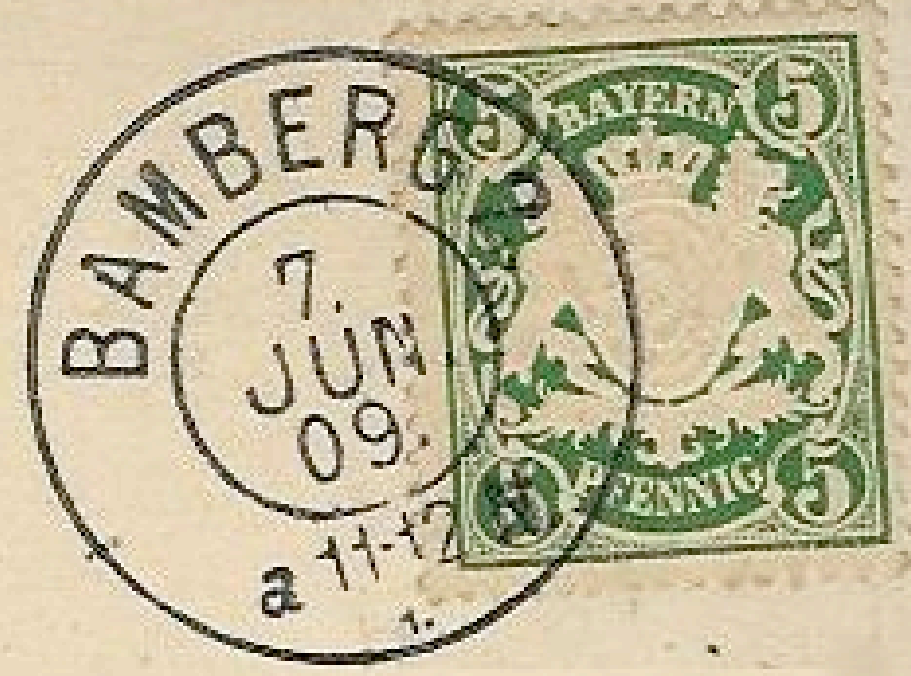

Sozialistische

Umbenennungen 


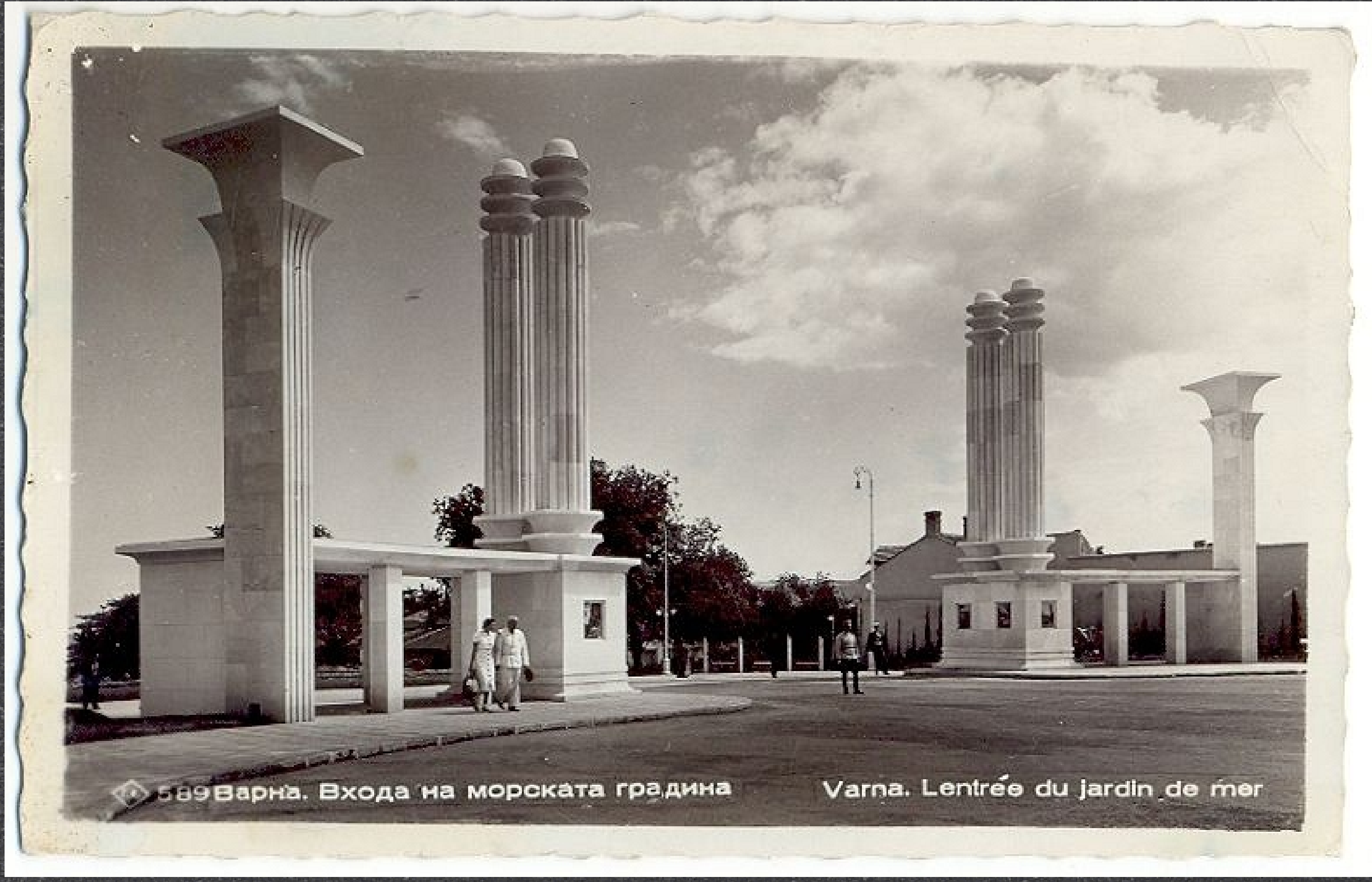

Варна. Входа на морската градина 


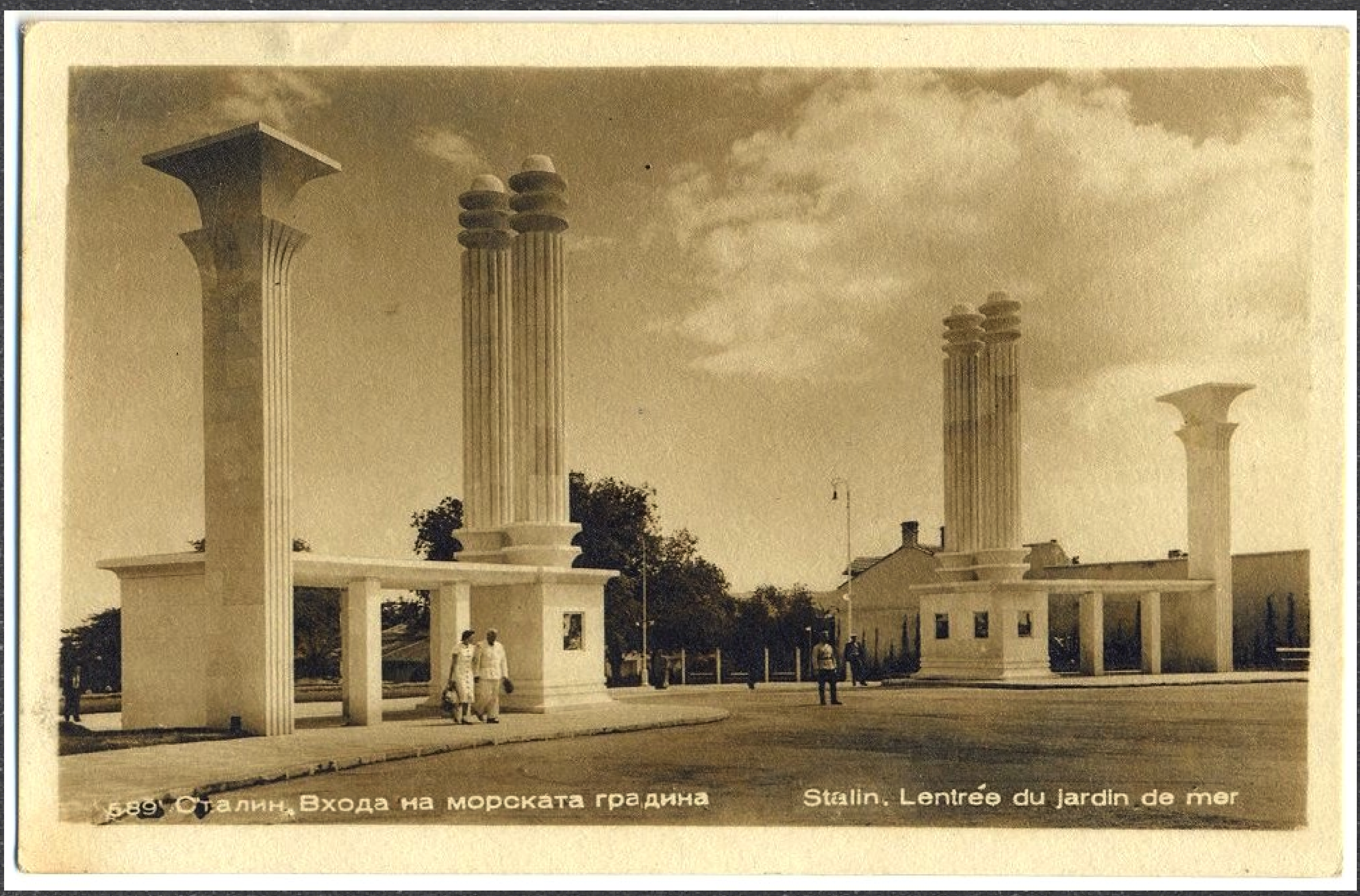

Сталин. Входа на морската градина 


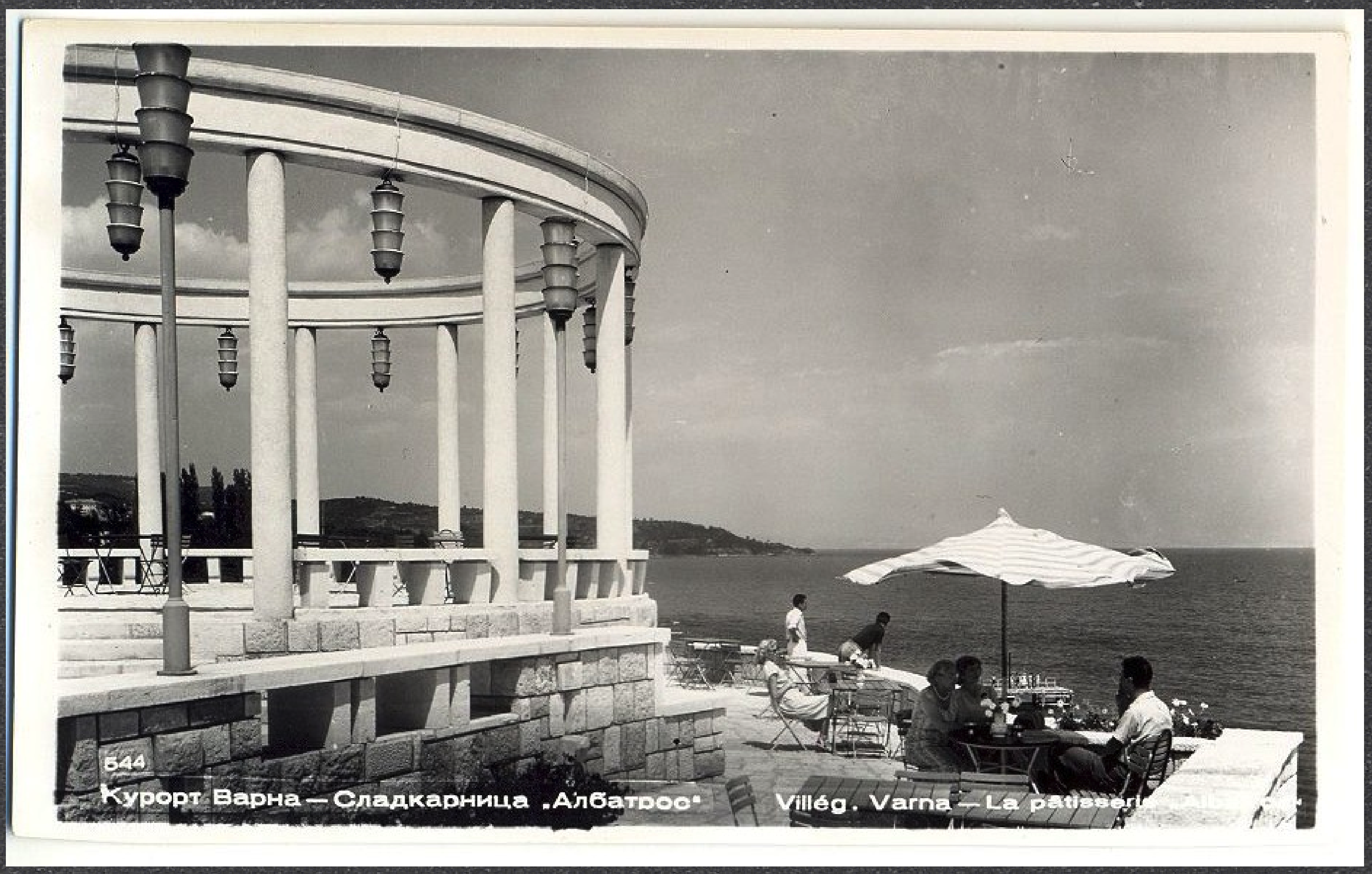




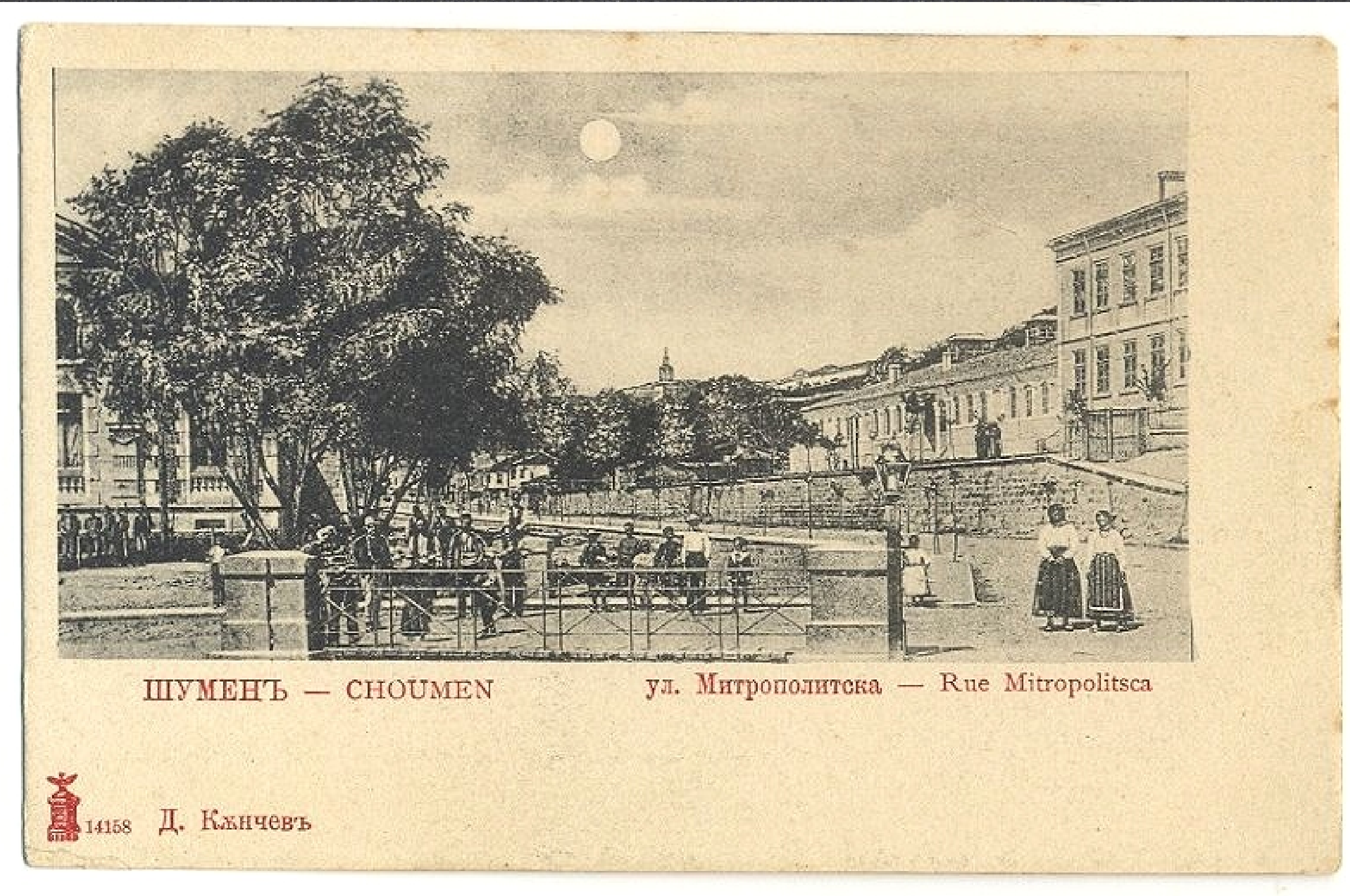

Шуменъ - ул. Митрополитска 


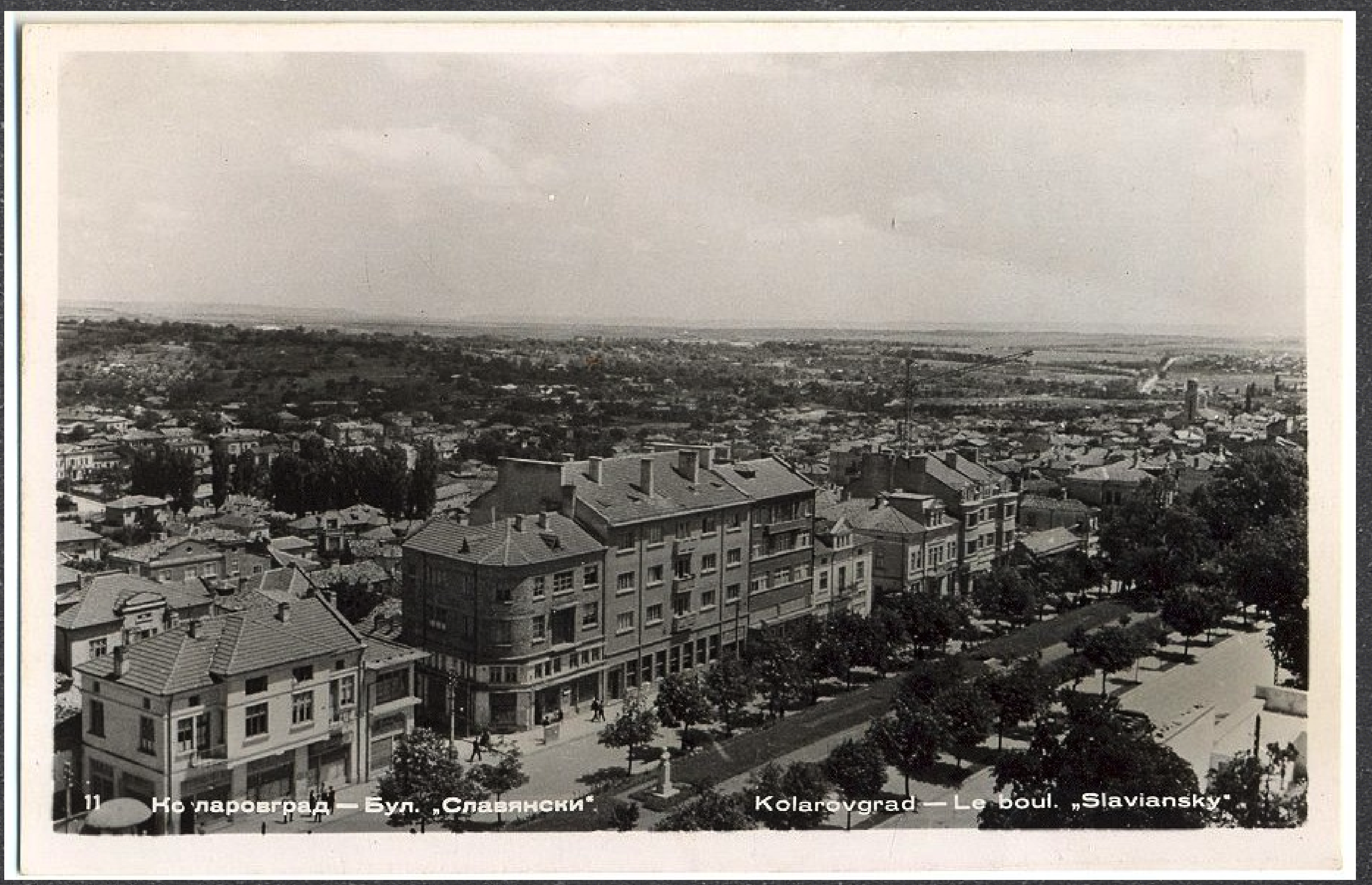

Коларовград - Бул. "Славянски" 


\section{Postkarte.}

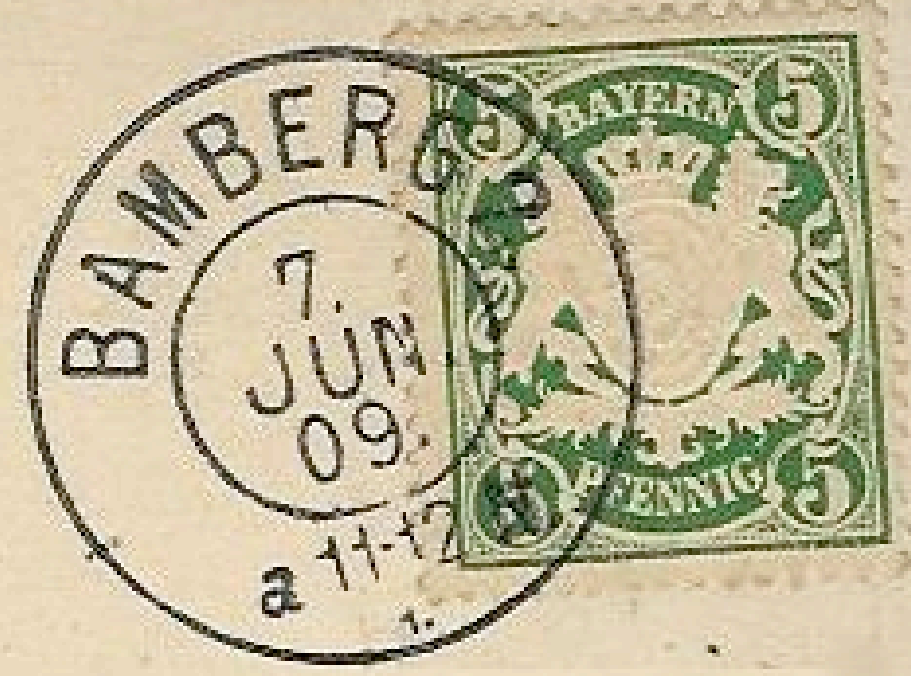

Phonetische und lexikalische Variation 
Sofia - St. Kyrill u. Methodius-Kirche

Черквата Св. Кирилъ и Методий въ София

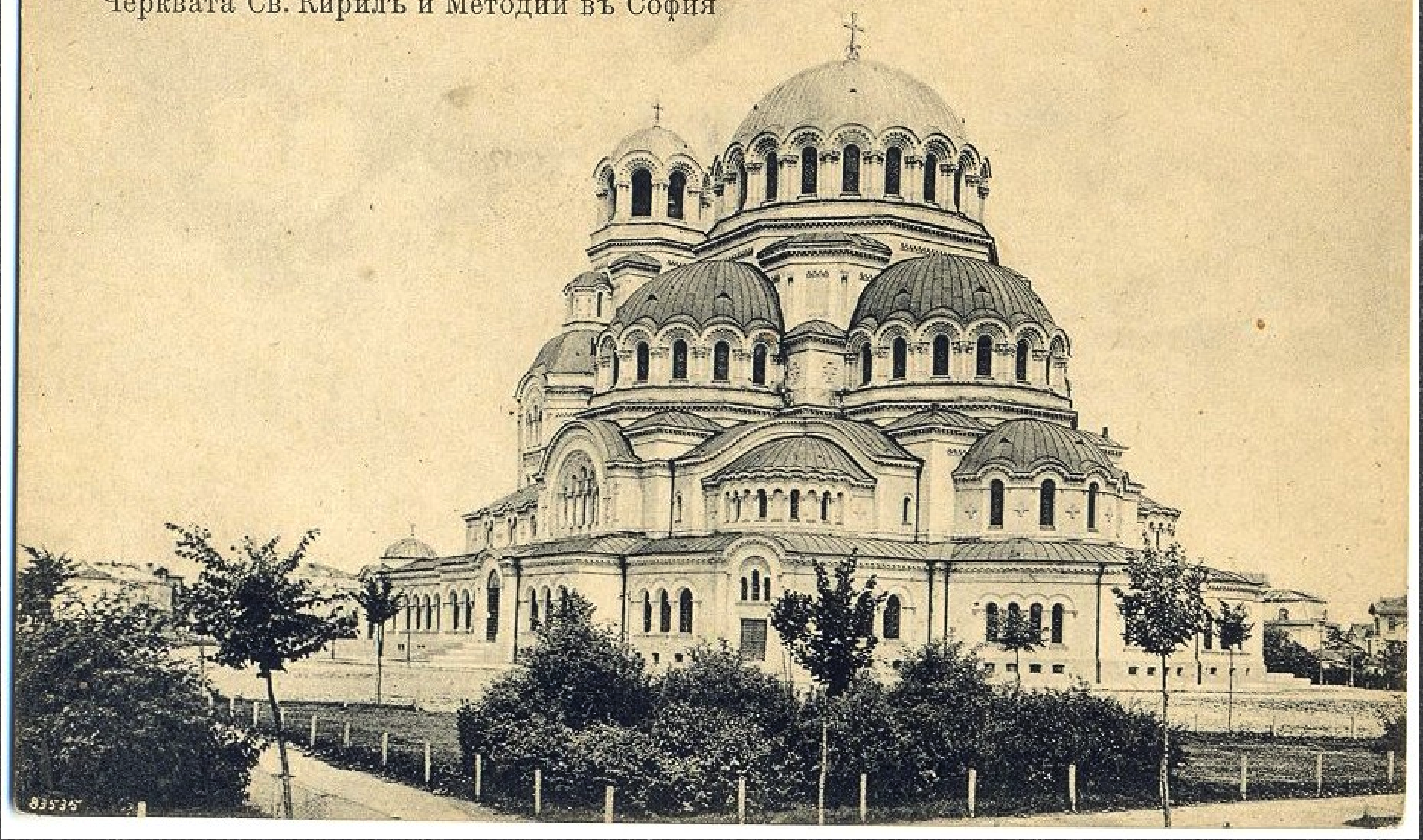

Sofia - St. Kyrill u. Methodius-Kirche черквата Св. Кириль и Методи въ София 
Перквата „св. Kраль“. - Die Kirche „Sw. Kral

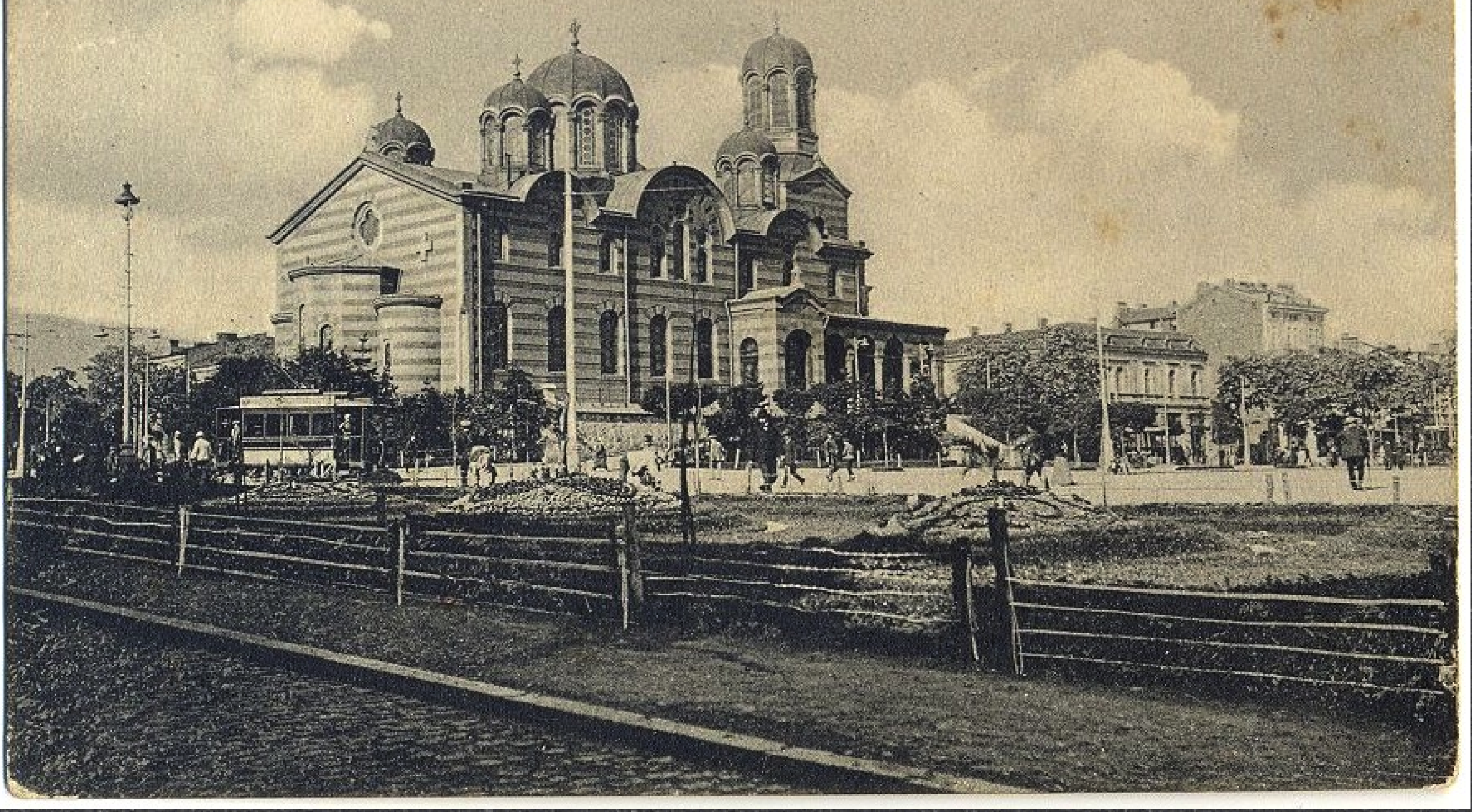

\section{щерквата "св. Краль" Die Kirche "Sw. Kral"}




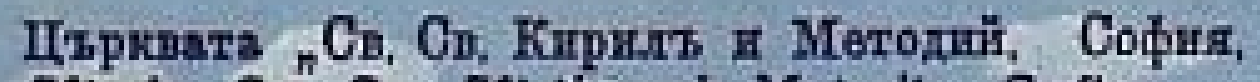
Kirche Sw. Sw. Kiril und Melodi. Sofia.

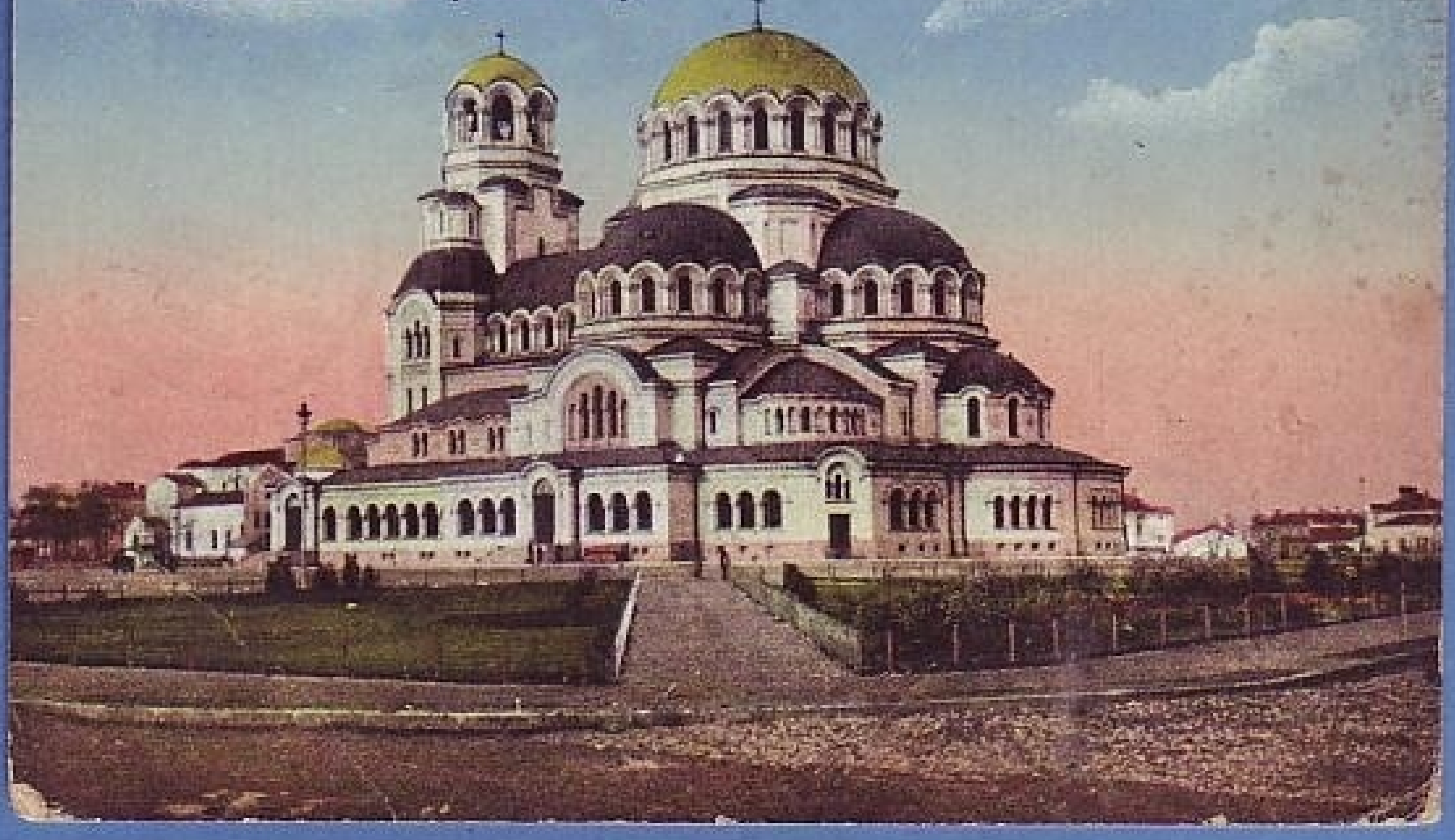

Lاърквата "Св.Св. Кирилъ и Методий. София,

Kirche Sw. Sw. Kiril und Metodi. Sofia. 


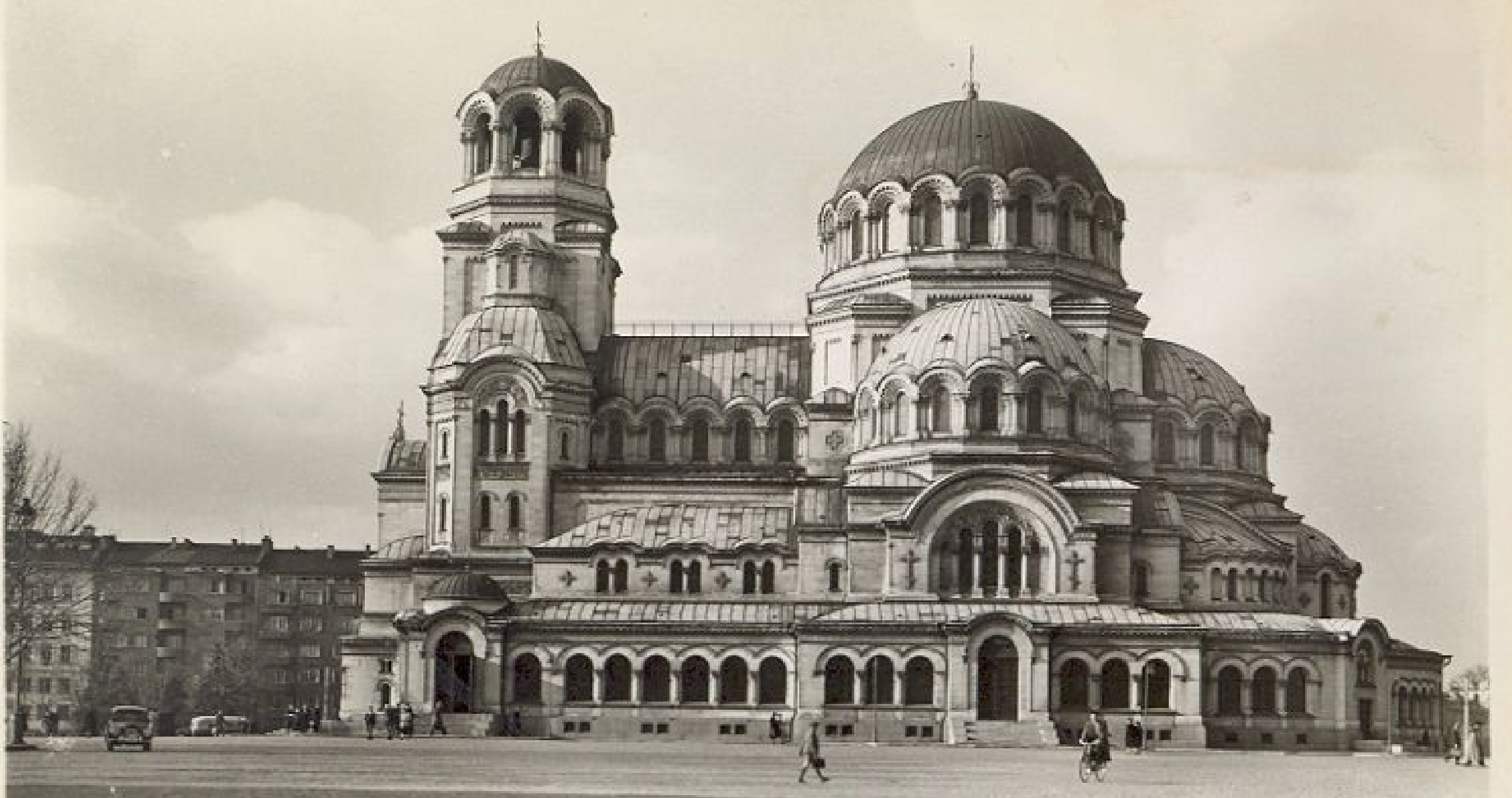

104 София-Xрам-памотник ,An. Hопски"

Sofia - L'Gallso monumont , Al. Novsky"

София - Храм-mаметник "Ал. Невски" Sofia - L'église monument "Al. Nevsky" 


\section{Postkarte.}

\section{черква}

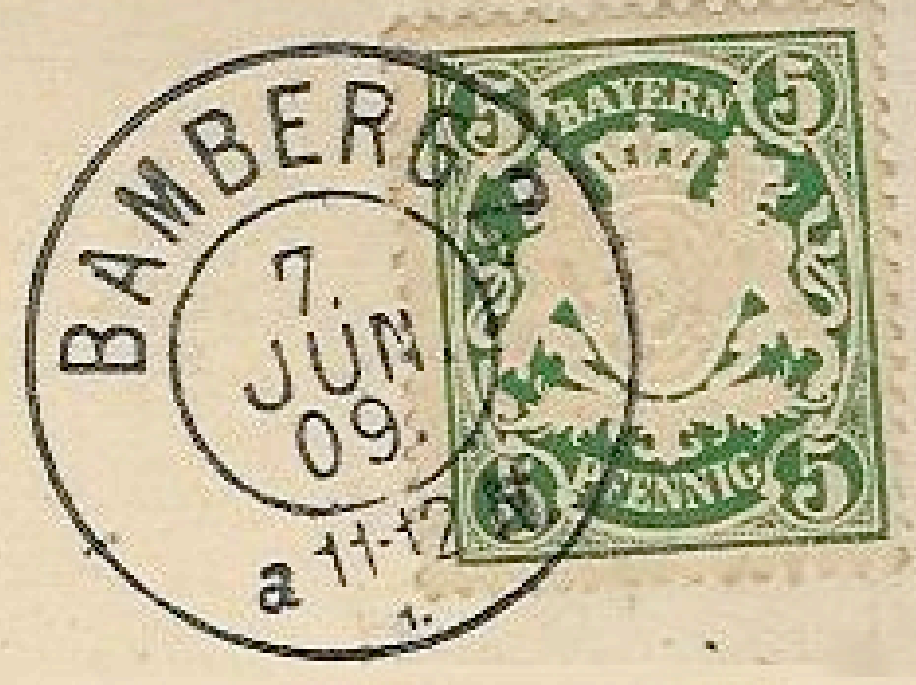

\section{церква}

\section{църква}

\section{храм}




\section{Postkarte. \\ Miladinov 1915: \\ черква черква Kirche $f$ церква s. unter Черква \\ ЦерКва цьрква s. unter Черква \\ ЦЪРКВа Petkov/Gutschmidt 2003: църква $f$. Kirche храм черква $f$. dass wie църква церква - kein Eintrag}




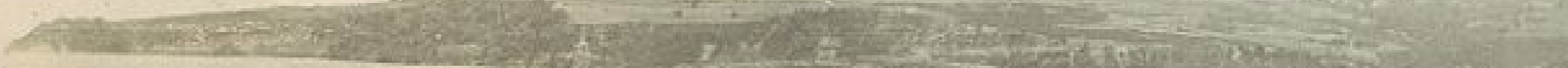

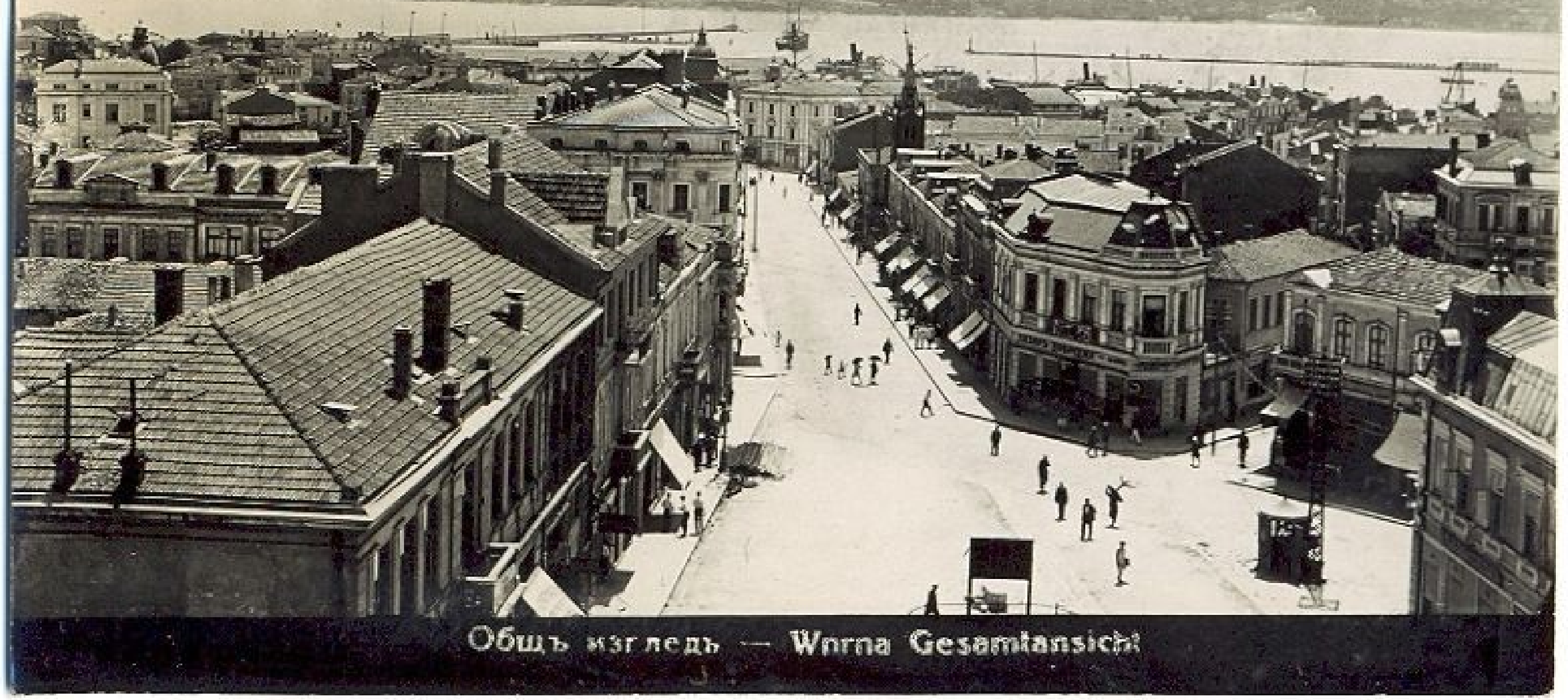

Общъ изгледъ - Warna Gesamtansicht 


\section{Postkarte.}

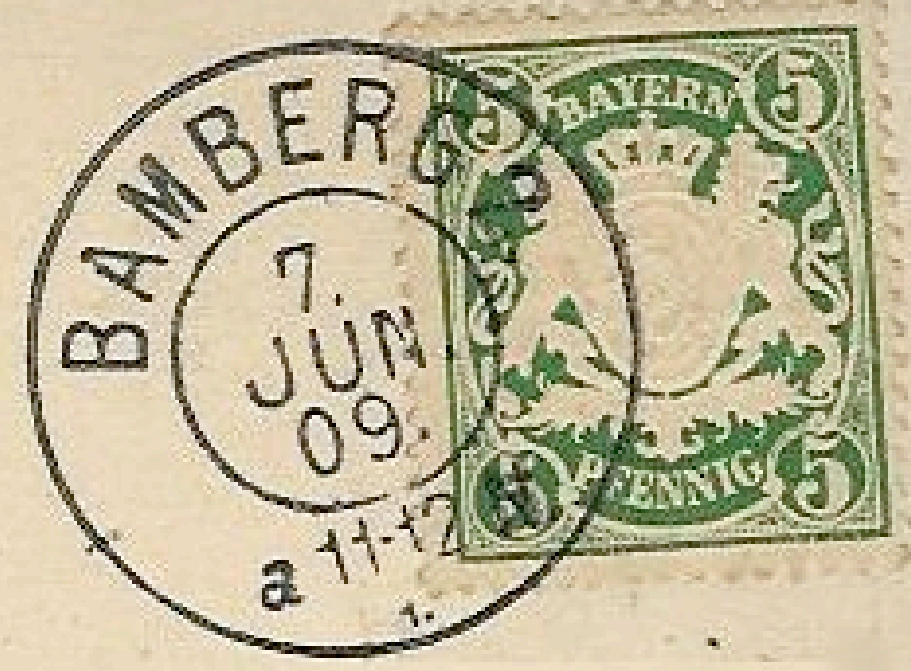

Morphosyntax:

Izgled + Präpos. 


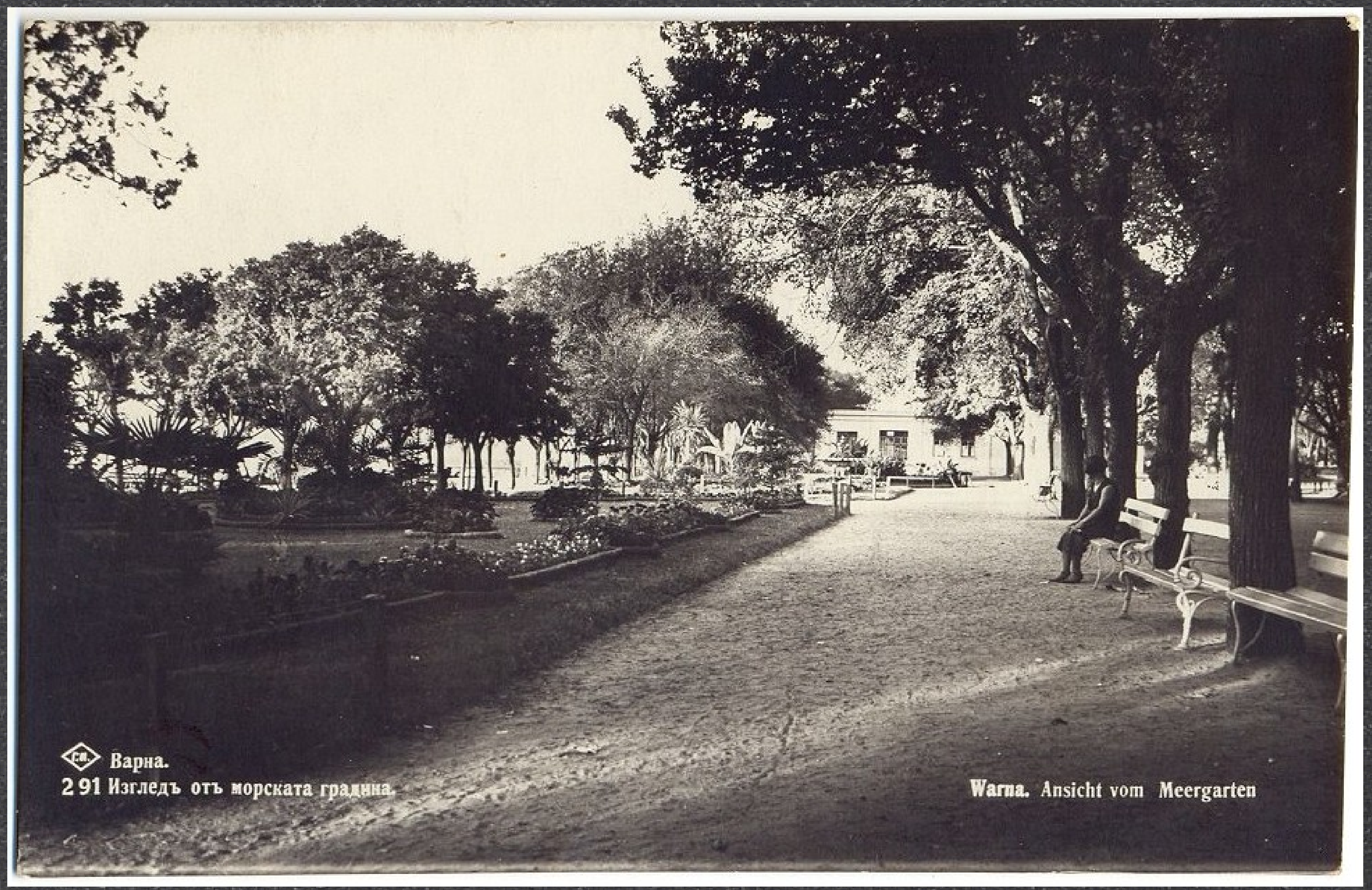

Варна. Изгледъ оть морската градина Warna. Ansicht vom Meergarten 


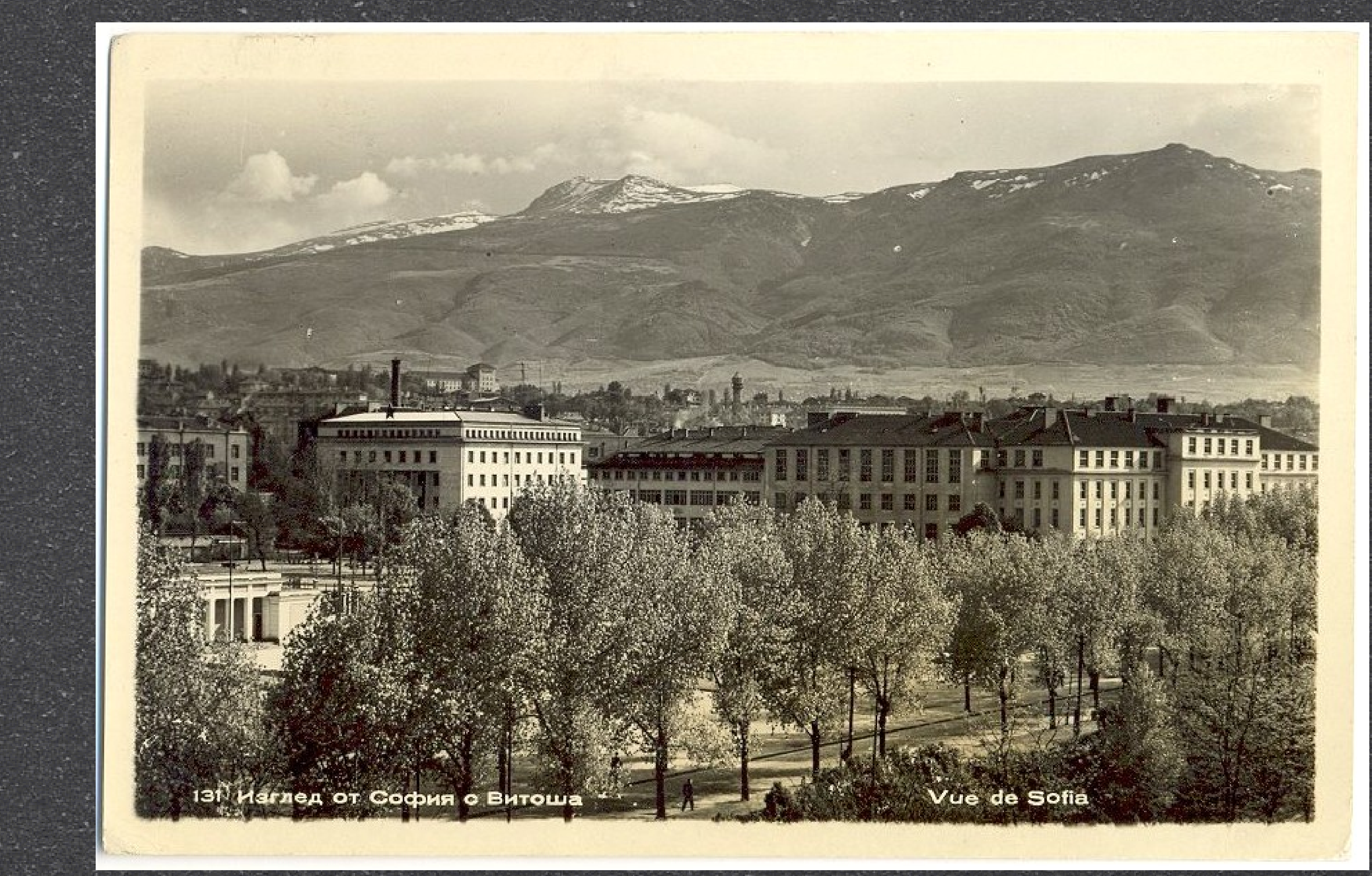

\section{Изглед от София с Витоша Ansicht von Sofia mit Witoscha}




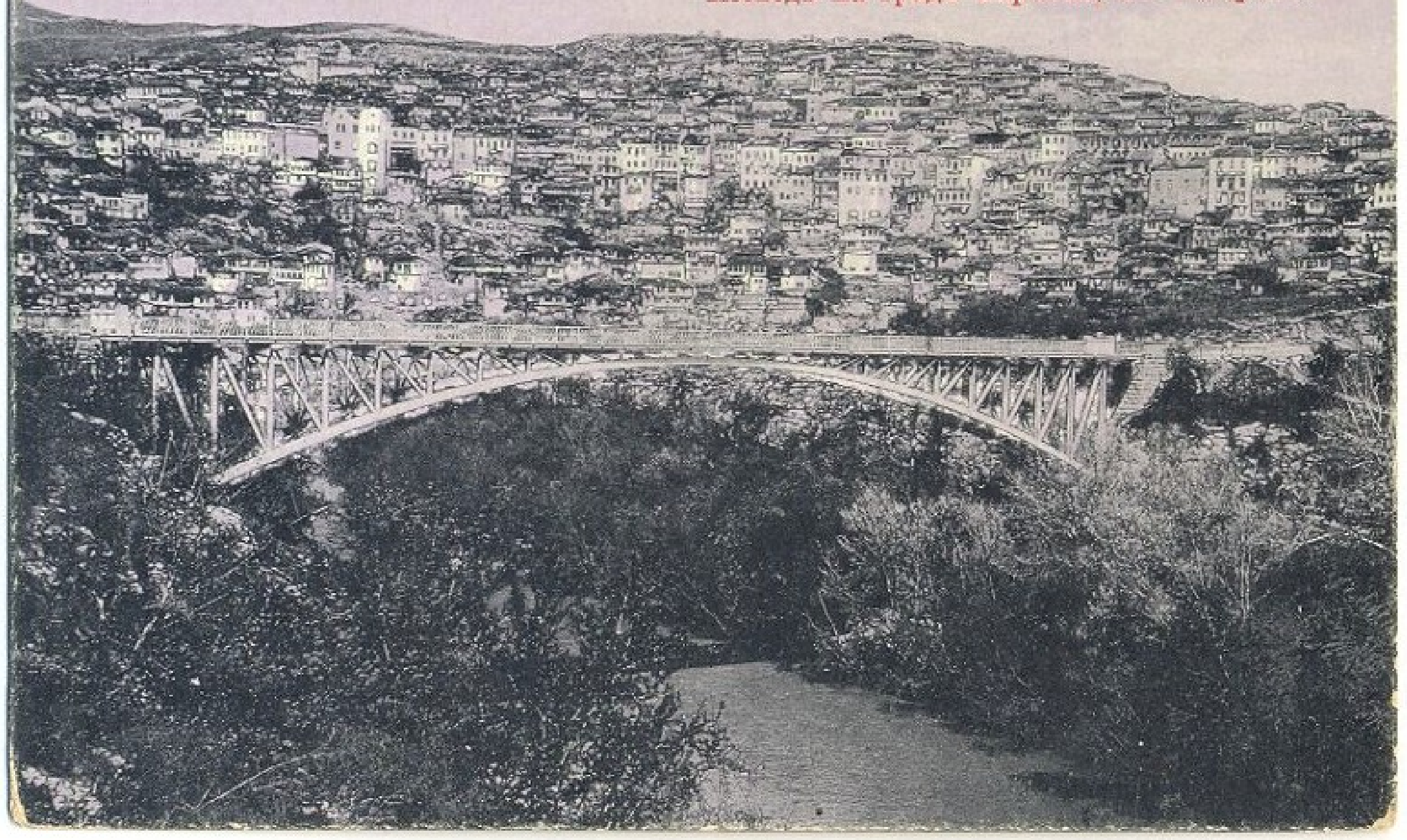

Изгледъ наградъ Търново, отъ казармить • Ansicht von/Blick auf Tarnovo, von den Kasernen aus 


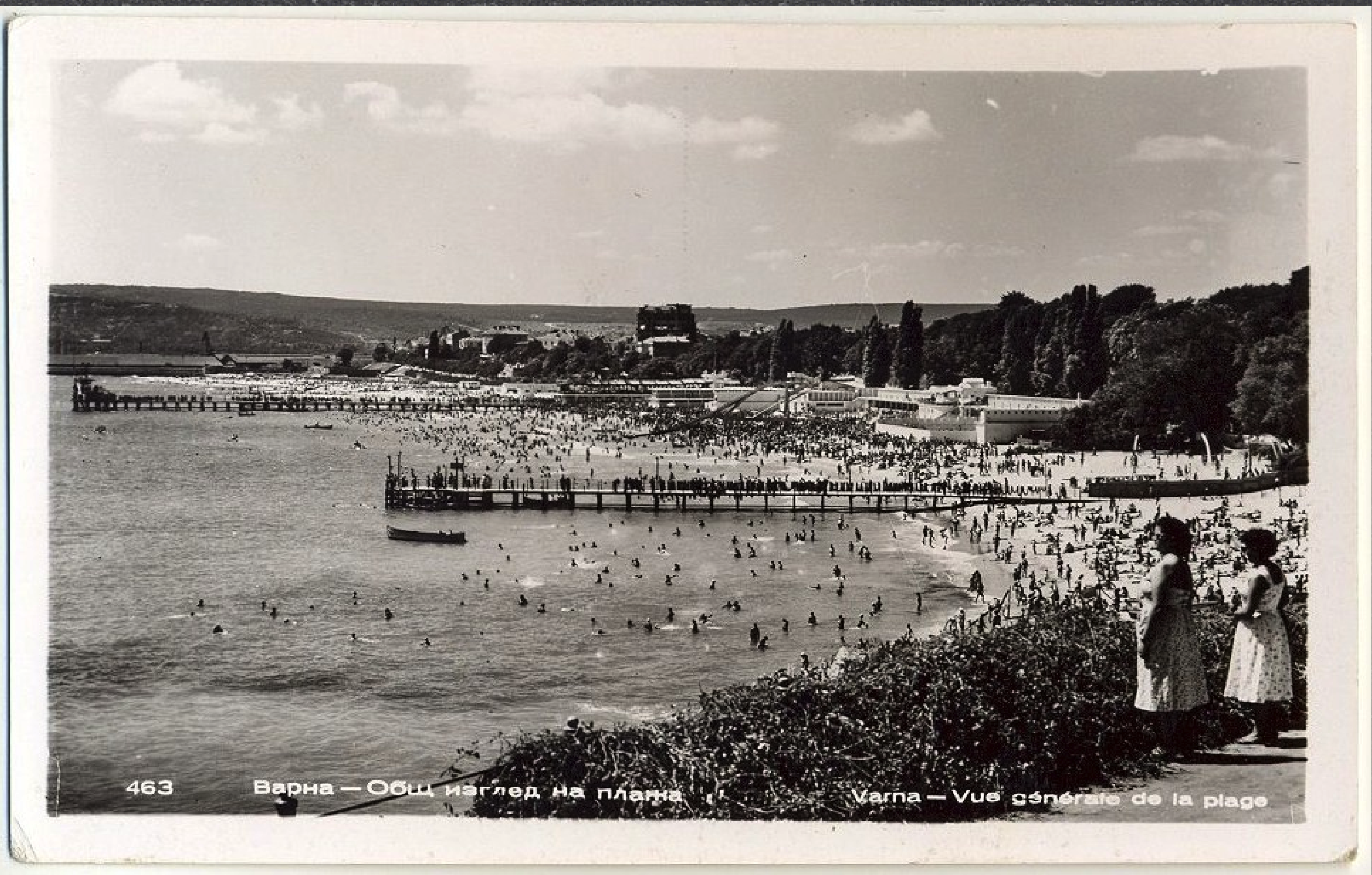

\section{Варна - Общ изглед на плажа Ansicht des Strandes? Blick auf den Strand?}


Изгедль на градъ Търиово, сь трапезица

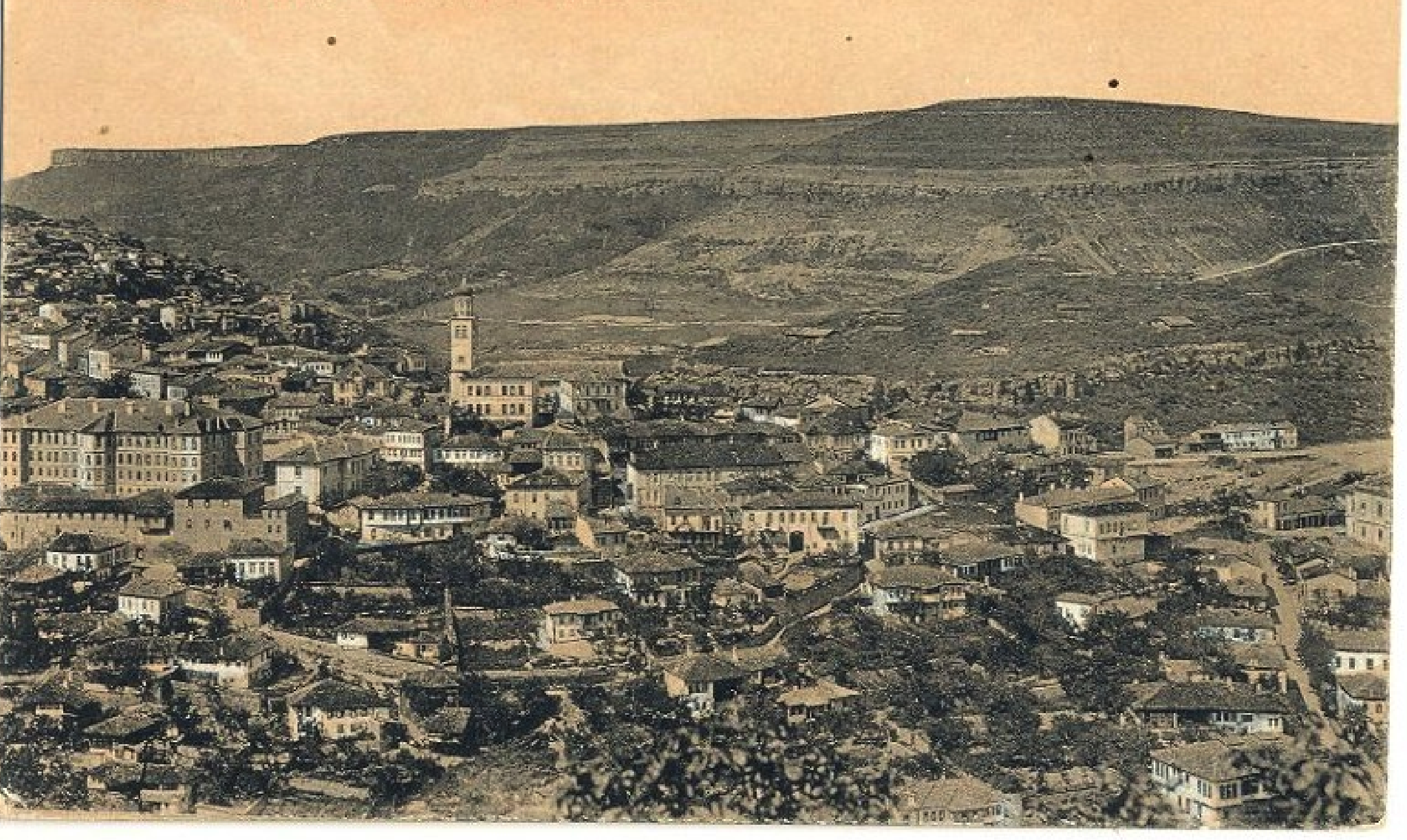

Ne:

Изгледъ на градъ Търново, съ

трапезица

Ansicht von Tarnovo, von/mit Tr.? 
ѝзглед $m$-и 1 (външност) о Pl Aussehen $n$ -s, Äußere(s) $n 222$ (гледка) Aussicht fll, Ausblick m4: ста̀я с $\sim$ към морѐто, към планина̀та, към уेлицата, към градйната ein Zimmer mit Ausblick [Aussicht] auf das Meer, auf das Ge'birge, auf die Straße, nach dem [in den] Garten; отту̀к ѝма [се открйва] чудѐсен $\sim$ von hier aus hat man [bietet sich] eine herrliche Aussicht [ein herrlicher Ausblick] 3 (картичка) Ansichtskarte fl8, Ansicht fl8 4 (перспектива) meist Pl Aussicht f18: то̀й ѝма добрѝ, ло̀ши, ма̀лки, блестя̀щи -и еr hat gute, schlechte, ge'ringe, glänzende Aussichten; ѝма -и за нш etw ist [steht] in Aussicht; ѝма -и за добра̀ реко̀лта, за повишѐнието му eine gute Ernte, seine Be'förderung ist [steht] in Aussicht; ѝмам -и за нш [да ... ] etw in Aussicht haben 62; то̀й ѝма -и за но̀во назначѐние, да полу̀чи

\section{изглед} KbM
Petkov,

Gutschmidt 2005 


\section{Postkarte. \\ Lex: изглед към 'Blickad ar}

Postkarten:

\section{изгледъ отъ 'Ansicht des'} изглед на 'Ansicht

\section{des' ('Blick auf')}




$$
\text { Postatere (5) }
$$

Übersetzungsfragen:

Verhältnis der Texte

zueinander 
Дерквата „св. Kрраль“. - Die Kirche „Sw. Kral”.

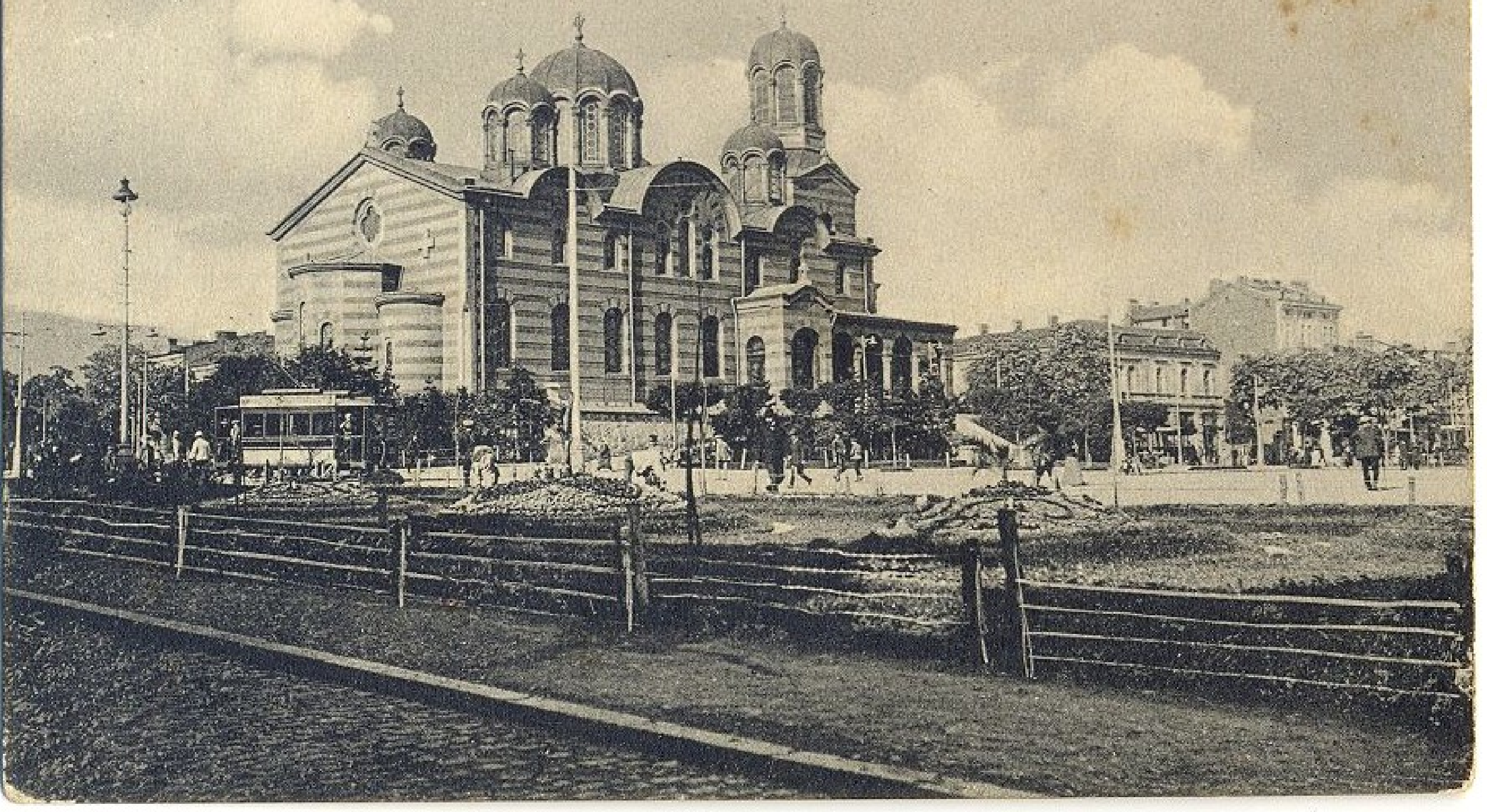

Церквата "св. Краль" -

Die Kirche "Sw. Kral". 


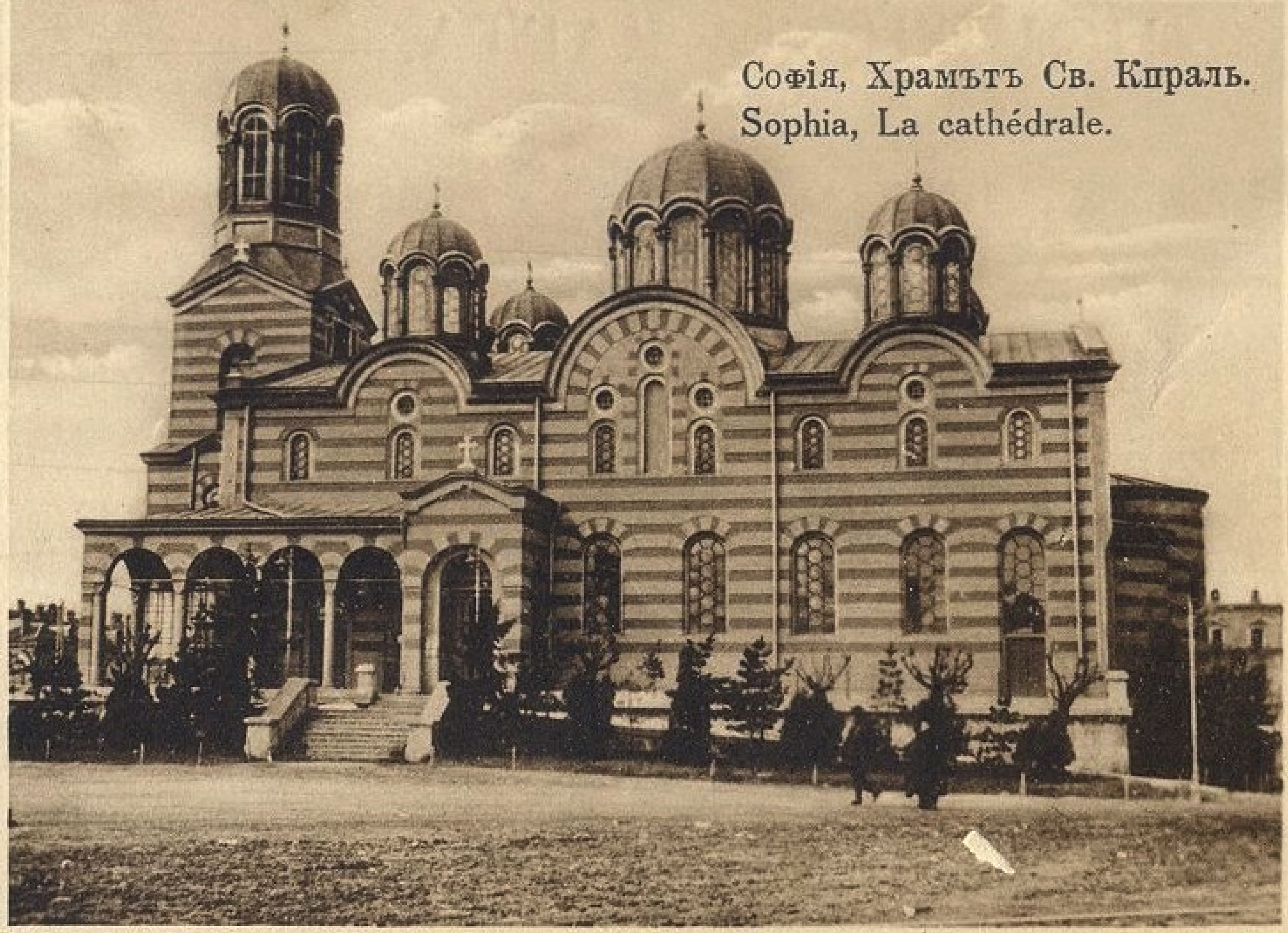

Софія. Храмъть Св. Кпраль Sophia, La cathédrale. 


\section{Postkarte.}

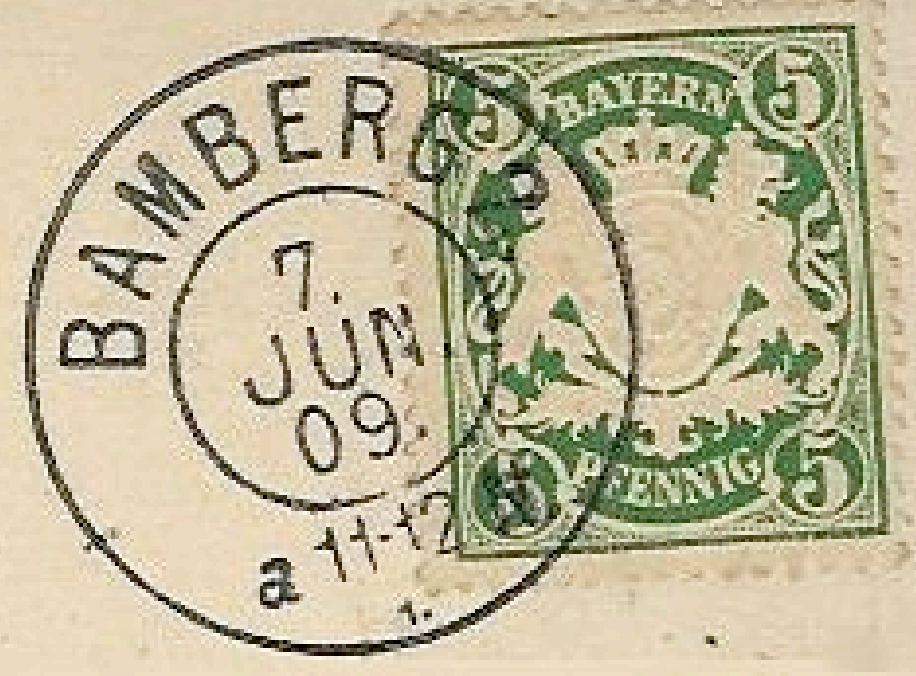

\section{Zusammenfassung}




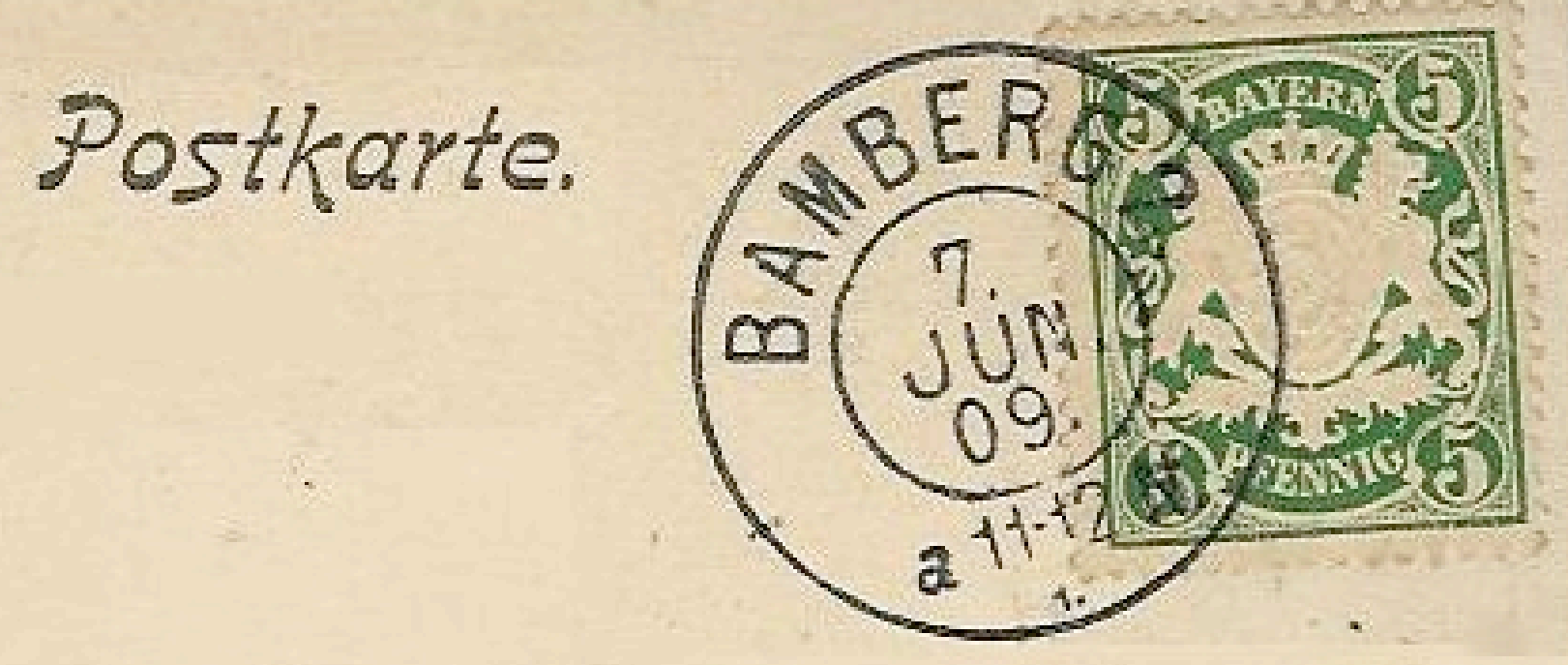

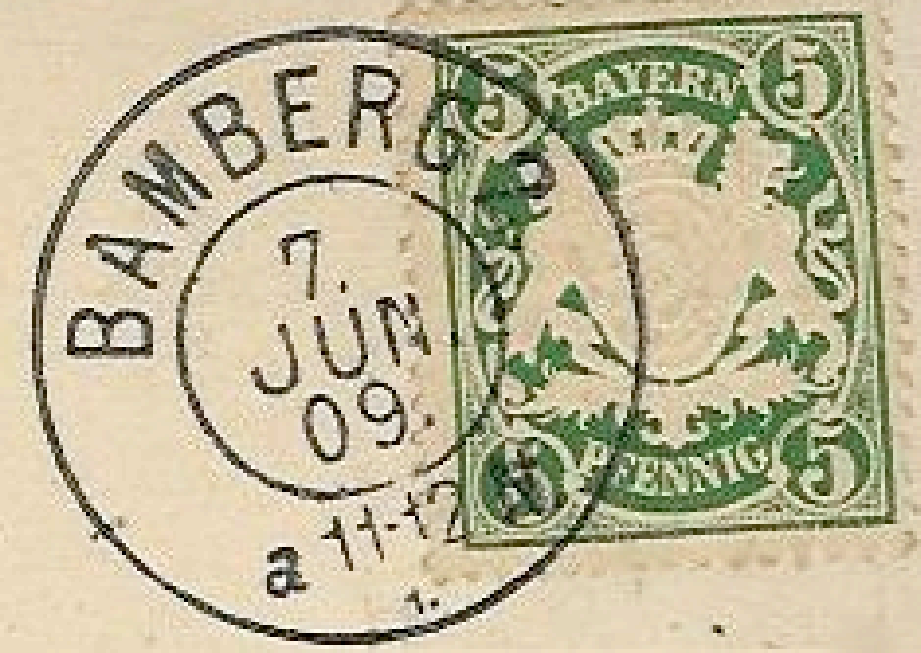

Die Postkarten belegen - die bulg. Sprach- und Kulturgesch. 1.H. 20. Jhs. 


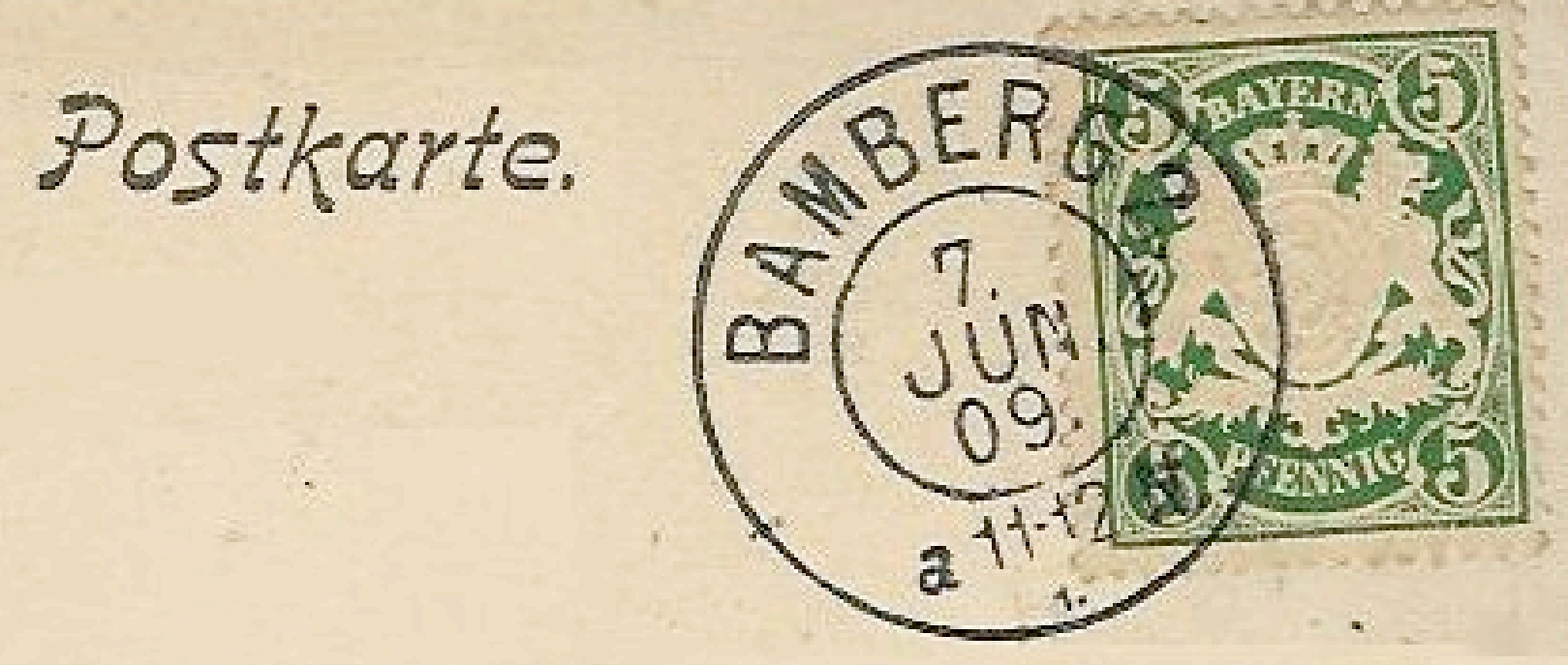

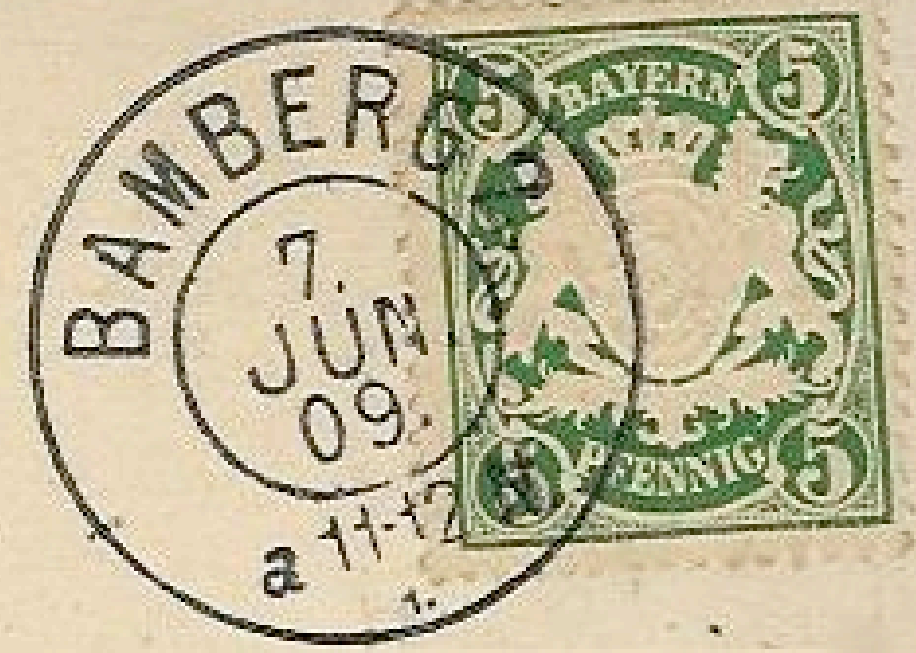

Die Postkarten belegen - Variationen und Fehler im Sprachgebrauch 


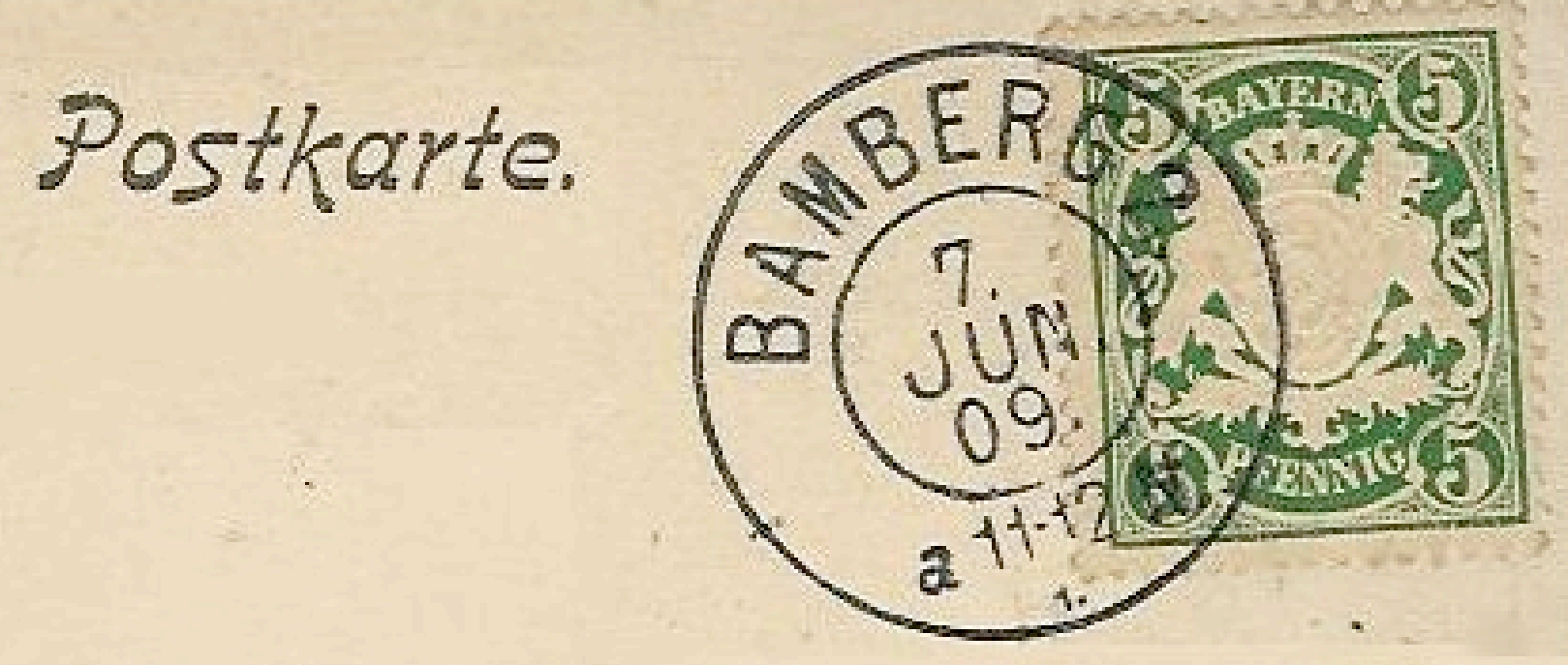

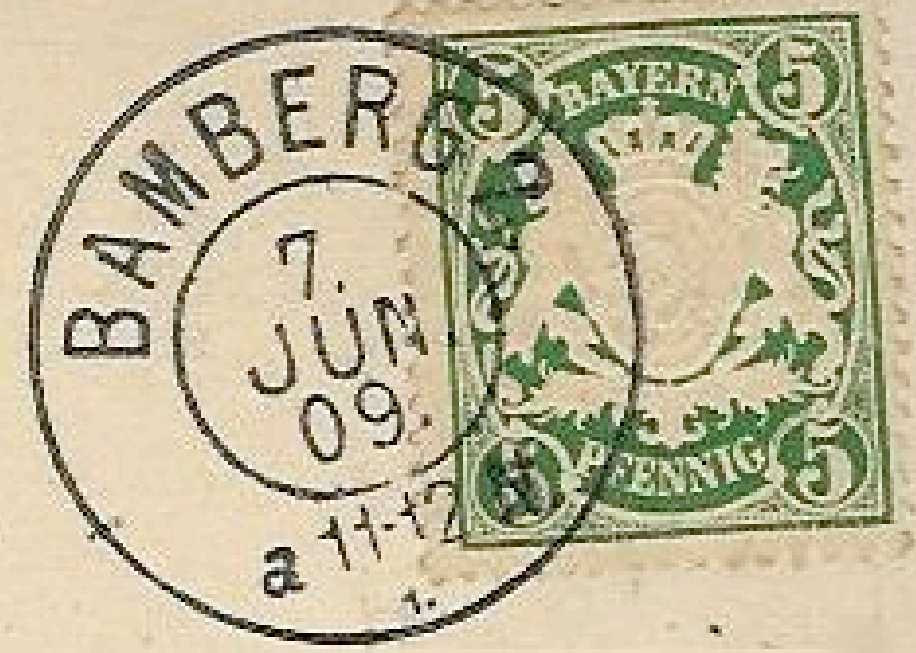

Die Postkarten belegen - älteren russischen Einfluß 


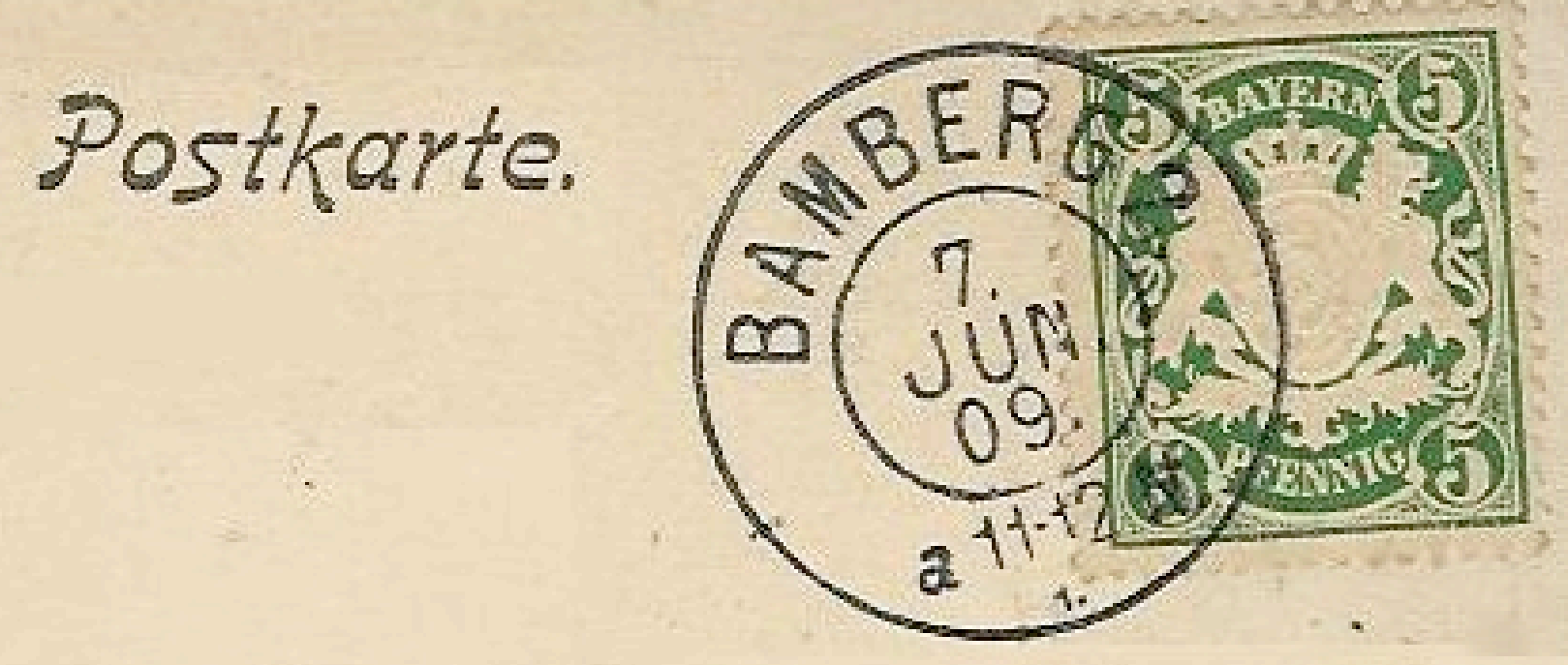

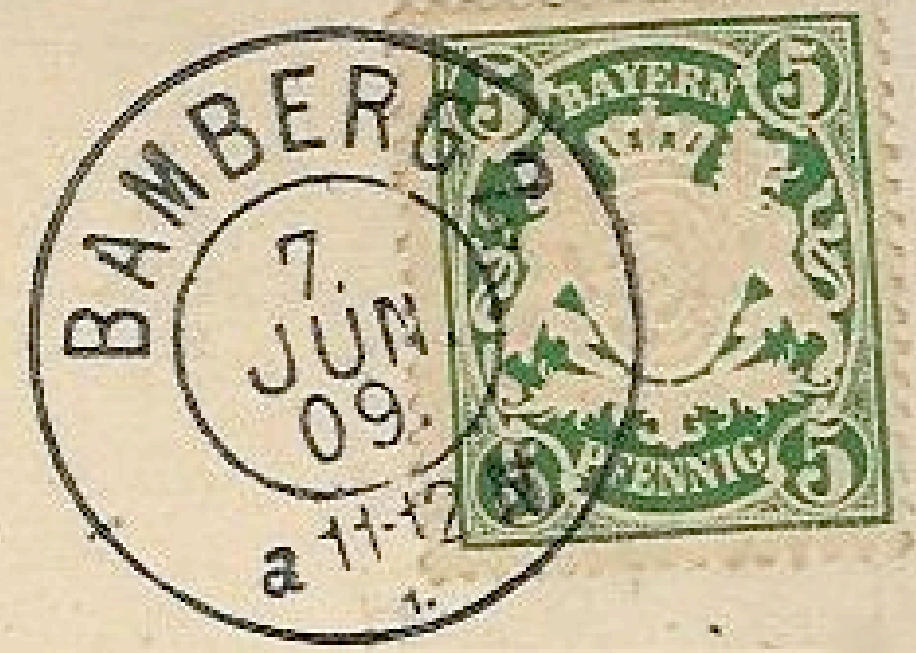

Die Postkarten belegen - bisher unbekannte morph. Variationen 


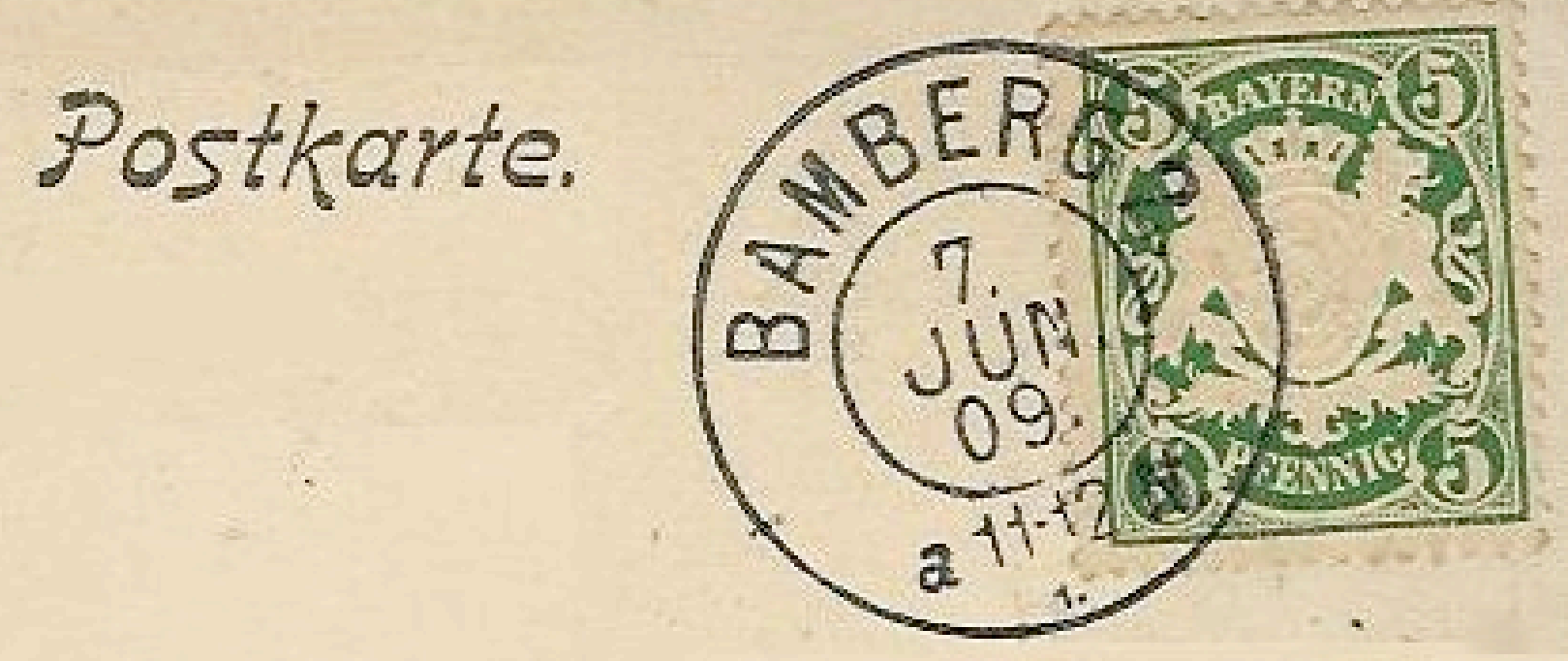

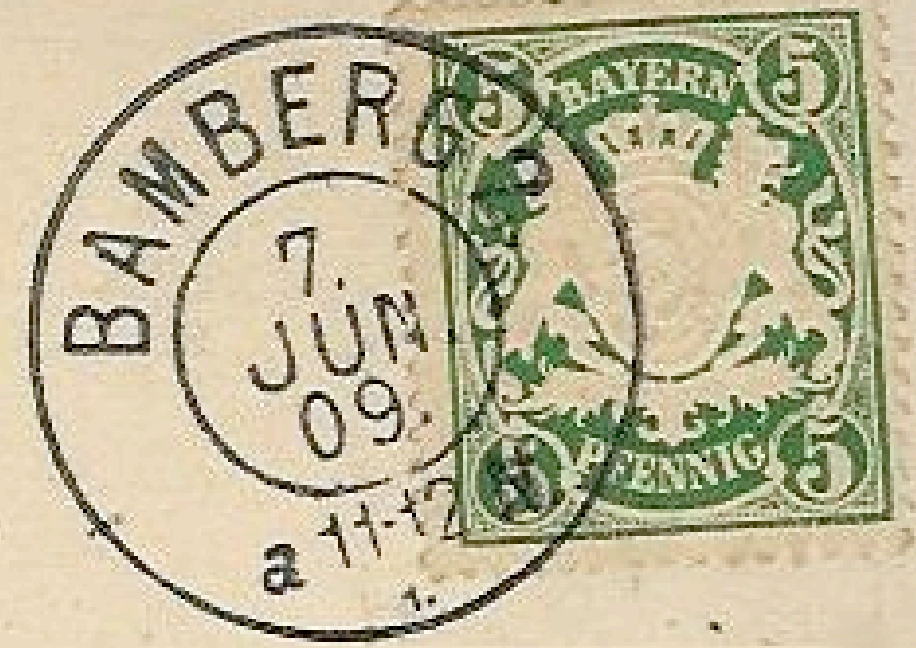

Die Postkarten belegen - im Lex. nicht belegte Präpositionalrektion 


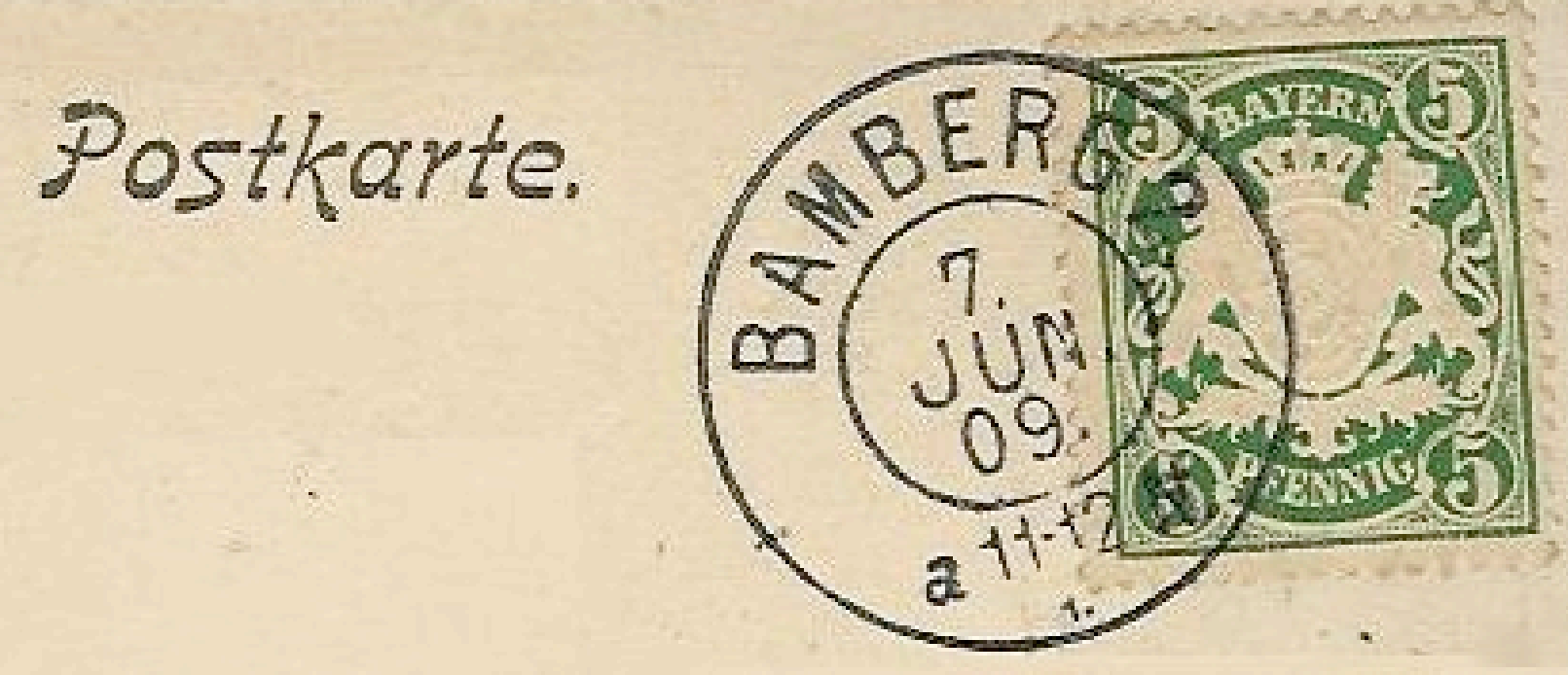

\section{und heutige Postkarten?}


kumeal 


\section{Postkarte.}

Google!

изглед към [морето]

изглед от [залата]

изглед на [града]

общ изглед 


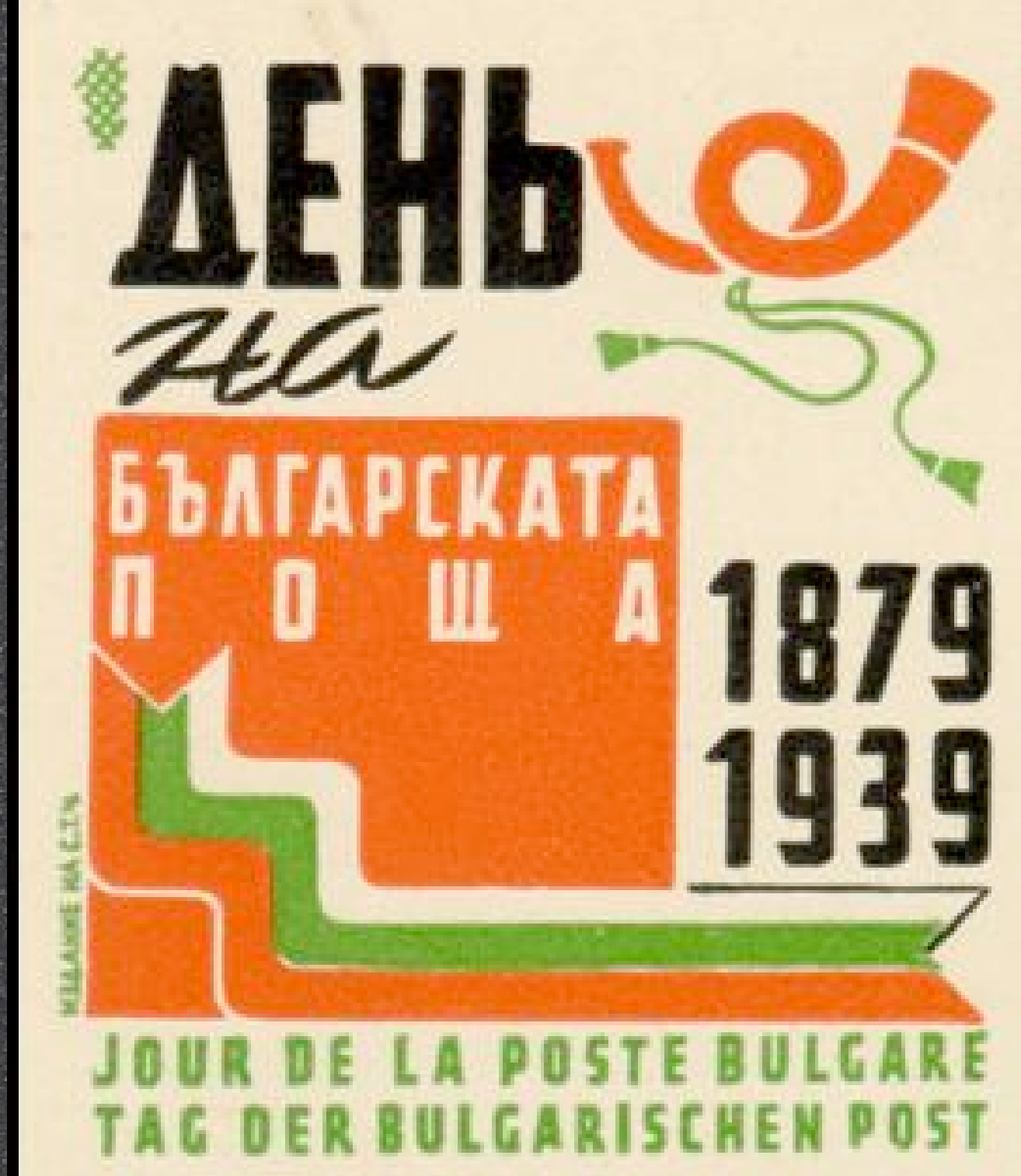

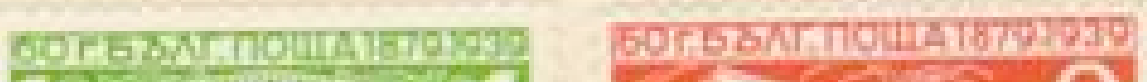

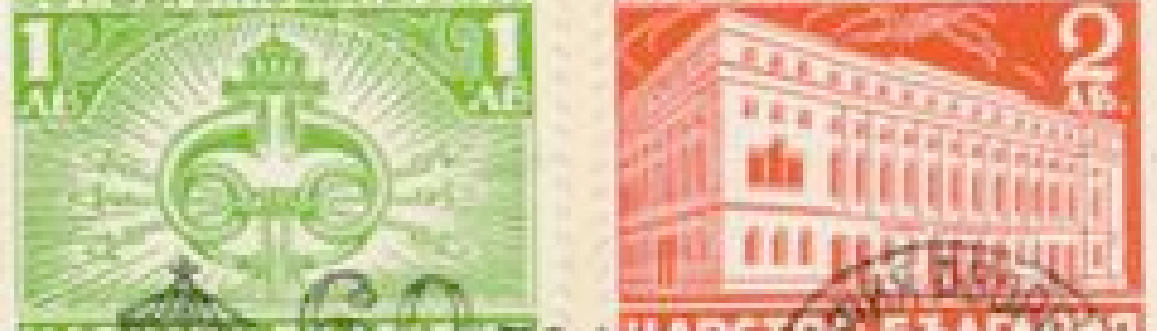

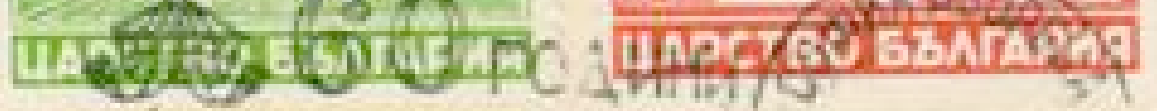

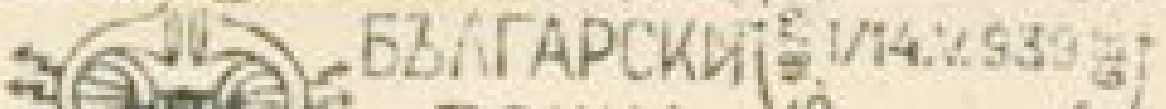

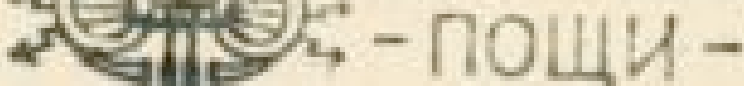

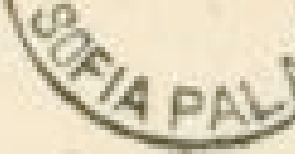

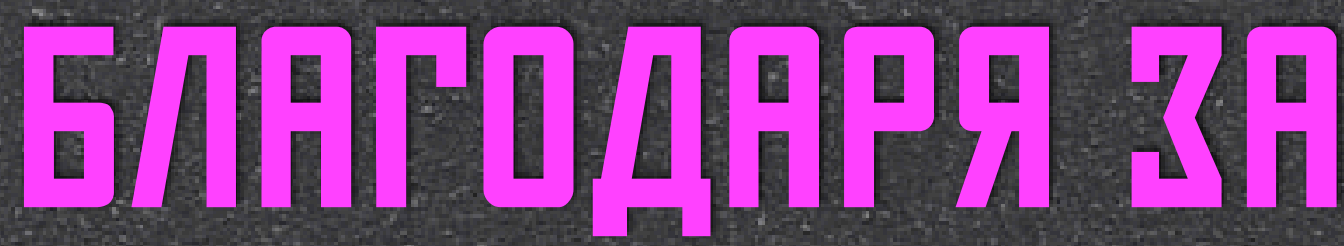

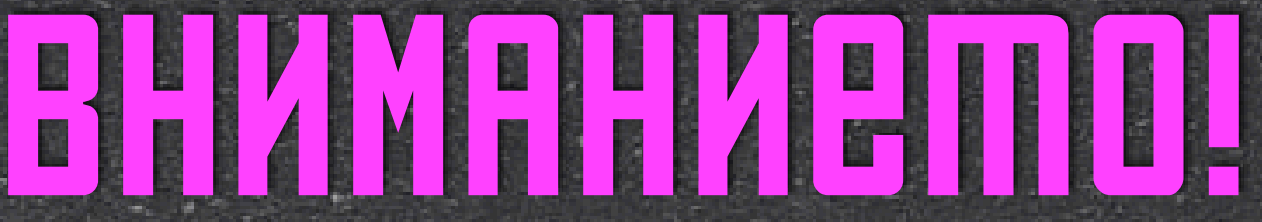


This presentation accompanies the following paper:

Sebastran Kempgen: Postkarten als quelle zur bulgarischen Sprachgeschichite der ersten Halfte des 20, Jahrhunderts. In P Kosta, D. Weiss (Hgg), Slavistische:Linguistik 2006/2007, Munchen 2009, $221-246$.

The paper is available online.

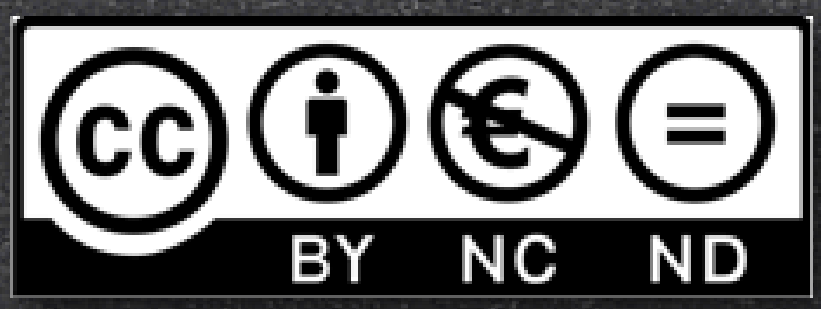

(c) Prof. Dr. Sebastian Kempgen 2021

ht tps:/ orcid. org/0000-0002-2534-9423.

D. 96045 Bamberg, University of Bamberg, Germany

sebastiankempgen@uni-bamberg.de

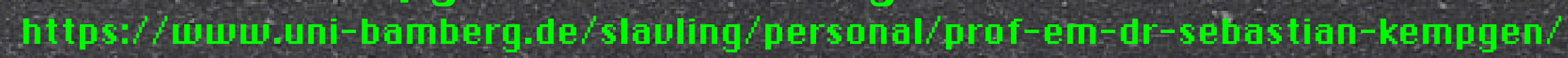

